\title{
Struktura i uwarunkowania kapitału społecznego lokalnych grup działania
}

Elżbieta Psyk-Piotrowska, Katarzyna Zajda Agnieszka Kretek-Kamińska, Danuta Walczak-Duraj 
尊 


\section{Struktura i uwarunkowania kapitału społecznego lokalnych grup działania}

Elżbieta Psyk-Piotrowska, Katarzyna Zajda Agnieszka Kretek-Kamińska, Danuta Walczak-Duraj
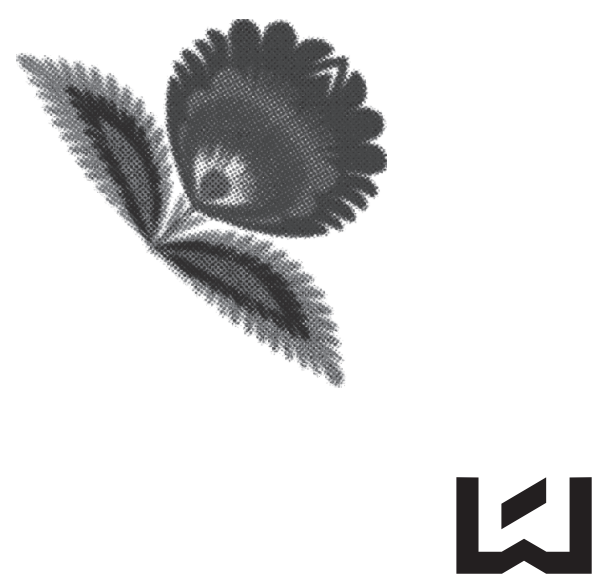

WYDAWNICTWO

UNIWERSYTETU

ŁÓDZKIEGO

ŁÓDŹ 2013 
Elżbieta Psyk-Piotrowska, Katarzyna Zajda - Katedra Socjologii Wsi i Miasta Instytut Socjologii, Uniwersytet Łódzki, 90-214 Łódź, ul. Rewolucji 1905 r., nr 41 Agnieszka Kretek-Kamińska - Katedra Metod i Technik Badań Społecznych Instytut Socjologii, Uniwersytet Łódzki, 90-214 Łódź, ul. Rewolucji 1905 r., nr 41 Danuta Walczak-Duraj - Katedra Socjologii Polityki i Moralności Instytut Socjologii, Uniwersytet Łódzki, 90-214 Łódź, ul. Rewolucji 1905 r., nr 41

\section{RECENZENT}

Hanna Podedworna

\section{REDAKTOR WYDAWNICTWA UŁ \\ Joanna Balcerak}

SKŁAD I ŁAMANIE

Oficyna Wydawnicza Edytor.org

\section{PROJEKT OKŁADKI}

Łukasz Orzechowski

C Copyright by Uniwersytet Łódzki, Łódź 2013

Wydane przez Wydawnictwo Uniwersytetu Łódzkiego

Wydanie I. W.06140.13.0.K

ISBN (wersja drukowana) 978-83-7525-884-4

ISBN (ebook) 978-83-7969-319-1

Wydawnictwo Uniwersytetu Łódzkiego
90-131 Łódź, ul. Lindleya 8
www.wydawnictwo.uni.lodz.pl
e-mail: ksiegarnia@uni.lodz.pl
tel. (42) 66558 63, faks (42) 6655862 


\section{SPIS TREŚCI}

ROZDZIAŁ I. PODEJŚCIE LEADER W POLSCE W ŚWIETLE ZAŁOŻEŃ BADAŃ

WŁASNYCH

1.1. LEADER w Polsce u progu nowego okresu programowania - przegląd literatury przedmiotu.

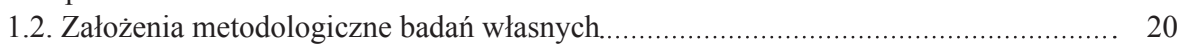

1.2.1. Podstawy teoretyczne podejmowanych badań........................................... 20

1.2.2. Założone cele i problematyka badania....................................................... 27

1.2.3. Zastosowana metoda i wykorzystane techniki badawcze ............................ 32

1.2.4. Charakterystyka lokalnych grup działania oraz założenia dotyczące próby badawczej......

ROZDZIAŁ II. CHARAKTERYSTYKA BADANEJ ZBIOROWOŚCI

2.1. Społeczno-demograficzne cechy respondentów a ich członkostwo w LGD ............... 47

2.2. Aktywność polityczna badanych ..................................................................... 54

ROZDZIAŁ III. STRUKTURA I POZIOM KAPITAŁU SPOŁECZNEGO LOKALNYCH

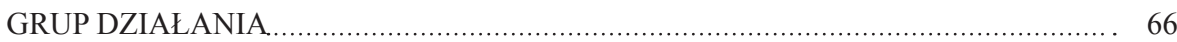

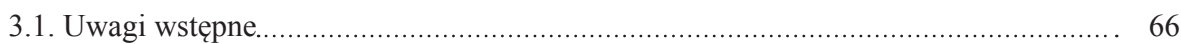

3.2. Charakterystyka komponentów kapitału społecznego badanych LGD ...................... 67

3.3. Struktura i poziom kapitału społecznego LGD z wybranych województw - konkluzje.

ROZDZIAŁ IV. UWARUNKOWANIA KAPITAŁU SPOŁECZNEGO LGD REPREZENTUJĄCYCH WOJEWÓDZTWA, NA TERENIE KTÓRYCH FUNKCJONUJĄ NAJWIĘ-

KSZE I NAJMNIEJSZE SIECI TEGO TYPU ORGANIZACJI.....

4.1. Charakterystyki społeczno-demograficzne członków wybranych LGD oraz aktywność grup w zakresie realizacji projektów.

4.2. Struktura kapitału społecznego wybranych LGD......

4.3. Poziom aktywności gospodarczej na obszarze partnerstw terytorialnych a poziom kapitału społecznego LGD.

4.3.1. Struktura gospodarstw rolnych obszaru partnerstw w 2010 r........................ 113

4.3.2. Stopa bezrobocia na obszarze partnerstw w 2010 r...................................... 114

4.3.3. Liczba grup producentów rolnych (na obszarze partnerstw) w 2010 r............. 115

4.3.4. Liczba firm prowadzonych przez osoby fizyczne poza sektorem rolnym (na obszarze partnerstwa) w $2010 \mathrm{r}$.

4.3.5. Poziom kapitału społecznego w LGD funkcjonujących na obszarach o różnym poziomie rozwoju gospodarczego. 
4.4. Poziom aktywności społecznej na obszarze partnerstw terytorialnych a poziom kapitału społecznego LGD.

4.4.1. Liczba aktywnych KGW i innych tradycyjnych form współpracy mieszkańców wsi na obszarze partnerstw w $2010 \mathrm{r}$.

4.4.2. Liczba funkcjonujących na obszarze partnerstw aktywnych organizacji pozarządowych nowego typu oraz stowarzyszeń zwykłych w $2010 \mathrm{r}$.

4.4.3. Dynamika przyrostu lokalnych grup działania w województwie.

4.5. Poziom współpracy międzysektorowej na obszarze partnerstw terytorialnych a poziom kapitału społecznego LGD.

Spis tabel.

Spis wykresów.

Załączniki. 


\section{WSTĘP}

Książka jest pokłosiem kilkunastomiesięcznych badań i analiz socjologicznych, prowadzonych przez czteroosobowy zespół naukowy Instytutu Socjologii UŁ w ramach umowy nr 6996/B/H03/2011/40 o realizację projektu badawczego pt. Struktura i uwarunkowania kapitatu społecznego lokalnych grup działania ${ }^{1}$.

Problematyka kapitału społecznego zajmuje sporo miejsca w rozważaniach teoretycznych i analizach empirycznych, jednakże kompleksowe badania poziomu i struktury kapitału społecznego na obszarach wiejskich nie były podejmowane. Tymczasem poziom kapitału społecznego jest jednym z ważnych czynników warunkujących zrównoważony i wielofunkcyjny rozwój wsi europejskich, w tym polskich. Korzystanie $\mathrm{z}$ funduszy unijnych otwiera możliwość budowania i wzmacniania różnych form współdziałania mieszkańców obszarów wiejskich na rzecz rozwoju własnych układów lokalnych. Środki te stanowią uzupełnienie zasobów własnych, ale częstokroć podstawą uzyskania dostępu do nich jest lokalna inicjatywa i aktywność wspólnotowa mieszkańców obszarów wiejskich.

Korzystny wpływ na rozwój aktywności mieszkańców wsi przypisuje się podejściu LEADER. Wszystkie jego „edycje” w Polsce przyczyniły się do powstania i rozrastania się partnerstw terytorialnych pod nazwą lokalne grupy działania (LGD). I chociaż są to struktury stosunkowo młode, to oczekuje się wzrostu ich znaczenia dla rozwoju polskiej wsi. Czynnikiem ważącym, jak dalece działanie tych partnerstw będzie skuteczne nie tylko dla rozwoju lokalnego, lecz także dla aktywizacji społeczności wiejskich jest poziom ich kapitału społecznego. Stąd próba podjęcia badania socjologicznego dotyczącego poziomu, struktury oraz uwarunkowań tego kapitału (realizowanego w dwóch rodzajach województw Polski: o najmniejszej i największej liczbie sieci tych struktur, funkcjonujących w czasie realizacji schematu II Pilotażowego Programu LEADER+). Ponadto zamierzałyśmy stwierdzić, czy istnieją różnice w poziomie kapitału społecznego, w jego strukturze na obszarach charakteryzujących się większą i mniejszą ilością LGD, a jeśli tak, to czym można je wyjaśniać.

${ }^{1}$ Inspiracją do podjęcia tego tematu były wieloletnie zainteresowania tą problematyką Katarzyny Zajdy, która w tym obszarze przygotowała zarówno pracę magisterską jak i doktorską, opublikowaną pt. Nowe formy kapitału społecznego wsi. Studium przypadku łódzkich lokalnych grup działania (2011). Umowę nr 6996/B/H03/2011/40 zawarto 2 sierpnia 2011 r. pomiędzy Narodowym Centrum Nauki w Krakowie a Uniwersytetem Łódzkim. 
Książka składa się z pięciu rozdziałów. W rozdziale pierwszym przedstawione są założenia metodologiczne badań własnych, poprzedzone przeglądem literatury przedmiotu. Wyodrębniono w niej cztery zakresy tematyczne, wokół których prowadzone są badania (najczęściej wycinkowe) związane z podejściem LEADER. Pierwszy dotyczy uwarunkowań procesu wdrażania tego podejścia na obszarach polskiej wsi, w drugim omówiono jego wpływ na sposób wykorzystania zasobów lokalnych wsi, a w trzecim - oddziaływanie na szerzej rozumiany rozwój społeczno-gospodarczy wsi. Czwartym zakresem problemowym, wyodrębnianym w literaturze, jest oddziaływanie podejścia LEADER na potencjał kapitału społecznego mieszkańców wsi.

W dalszej części rozdziału prezentowane są najważniejsze konkluzje (wynikające z badań polskich) ilustrujące cechy LGD oddziałujące na potencjał ich kapitału społecznego. Wnioski odnoszą się do wpływu procedur implementacyjnych podejścia LEADER na strukturę LGD i relacje pomiędzy członkami, a także cech strukturalnych LGD (liczebność członków, funkcjonowanie organów, zasięg działania partnerstw, stopień ich profesjonalizacji i ekonomizacji). Rozważania literaturowe kończy swoisty głos, ze strony autorek książki, w dyskusji na temat postulowanych zmian proceduralnych i kompetencyjnych LGD w nowym okresie programowania oraz potrzeby podjęcia bardziej kompleksowych badań związanych z implementacją podejścia LEADER w kontekście weryfikacji cech kapitału społecznego.

Podstawy teoretyczne podejmowanych badań rozpoczynają część prezentującą założenia metodologiczne badań własnych. Przyjęto w nich definicję kapitału społecznego autorstwa R. Putnama. W tej części pracy opisano wyniki najważniejszych polskich badań dotyczących kapitału społecznego, uwzględniając ich wnioski we własnym projekcie badawczym „Struktura i uwarunkowania kapitału społecznego lokalnych grup działania".

W dalszej części rozdziału zaprezentowano cele i problematykę badania. Postawiono pięć hipotez badawczych. Dla zbadania poziomu i struktury kapitału społecznego lokalnych grup działania określono zmienne trzech komponentów kapitału: zaufania członków LGD, podzielanych przez nich norm i wartości oraz sieci współpracy. Wyróżniono też zmienne składające się na społeczno-gospodarcze uwarunkowania obszarów, na których funkcjonują partnerstwa. Założenia metodologiczne dopełnia opis metody i technik badawczych, a zamyka charakterystyka LGD i założenia dotyczące próby badawczej.

Rozdział II obejmuje charakterystykę badanej zbiorowości, zarówno opis społeczno-demograficznych cech respondentów, ich członkostwa w LGD, jak i aktywności politycznej. Jest to pełny opis z punktu widzenia wymienionych cech całej zbiorowości respondentów (573 osób) z sześciu województw kraju.

W rozdziale III zawarta jest prezentacja danych dotyczących struktury kapitału społecznego lokalnych grup działania, z uwzględnieniem jego różnych aspektów. Scharakteryzowano i ujęto w indeksy składowe komponentów kapitału społecznego badanych LGD oraz oszacowano jego poziom jako pewnej całości, 
złożonej z wyróżnionych komponentów. Za empiryczne wskaźniki kapitału społecznego uznano zmienne stosunkowo najsilniej ze sobą skorelowane w ramach każdego z komponentów. Indeksy wyrażające wartości poszczególnych składowych każdego z komponentów poddano transformacji, sprowadzając indeks każdej składowej komponentu do postaci trzypunktowej (0-2), gdzie 2 oznacza najwyższą wartość. Suma wartości poszczególnych składowych dawała syntetyczną wartość każdego komponentu jako całości (0-6). Wyniki przeprowadzonych analiz pozwoliły scharakteryzować strukturę i oszacować poziom kapitału społecznego lokalnych grup działania z terenu sześciu województw Polski, były podstawą częściowej konfirmacji dwóch z pięciu hipotez (1. Kapitał społeczny LGD ma cechy kapitału zdekomponowanego, 2. Najniższym jego poziomem cechuje się komponent sieci).

Rozdział IV poświęcony jest charakterystyce wybranych czynników potencjalnie warunkujących kapitał społeczny lokalnych grup działania. Wśród nich wyróżniono gospodarcze, społeczne oraz te związane z kondycją współpracy sektora publicznego, społecznego i gospodarczego na obszarze partnerstw. Rozdział ten oparty jest przede wszystkim o dane zastane, które nie do końca spełniły oczekiwania badaczek. W związku z tym konieczne było ich rekodowanie według innych kryteriów niż wcześniej ustalone (podział na obszary o większej i mniejszej ilości sieci LGD).

Wnioski zawarte w rozdziale V zamykają część merytoryczną książki.

Wnosi ona istotny wkład w problematykę budowy kapitału społecznego na obszarach wiejskich. Spostrzeżenia i wnioski poczynione w oparciu o wyniki intensywnych i trudnych w realizacji badań naszego zespołu pozwalają na dalsze refleksje na temat szans na lokalne, oddolne inicjatywy społeczne, na decyzyjność mieszkańców wsi w rozwiązywaniu spraw, które przyczyniają się do rozwoju lokalnego (dokonywanego według zasad rozwoju zrównoważonego). Odnoszą się one również do możliwych do zastosowania udoskonaleń we wdrażaniu podejścia LEADER w Polsce.

Wyrażam szczere podziękowania członkiniom zespołu, a szczególnie dr Katarzynie Zajdzie za ogromny wkład w proces konceptualizacji projektu i realizacji badań terenowych oraz mgr Agnieszce Kretek-Kamińskiej, która dokonała mrówczej pracy w zakresie opracowania statystycznego zgromadzonego materiału, udzielała cennych uwag w zakresie rozwiązań metodologicznych problemów i pomagała $\mathrm{w}$ interpretacji zaskakujących czasem wyników. Podziękowanie należy się także obecnej doktorantce (która w trakcie badań była moją magistrantką), mgr Ewelinie Dzikowskiej, za systematyczną i solidną pomoc administracyjną. 

ROZDZIAŁ I

\section{PODEJŚCIE LEADER W POLSCE W ŚWIETLE ZAŁOŻEŃ BADAŃ WŁASNYCH}

\subsection{LEADER w Polsce u progu nowego okresu programowania - przegląd literatury przedmiotu}

Losy wdrażania podejścia LEADER w Polsce śledzi wielu badaczy. Doświadczenia w zakresie implementacji jego założeń (przez wybrane partnerstwa oraz kraje członkowskie UE) omawiano w literaturze już przed akcesją [por. Grochowska, Płonka 2002, Klepacka 2003]. Uwypuklano zalety podejścia, jego korzystne oddziaływanie na rozwój wiejskich społeczności. Jak pisze M. Wieruszewska: „LEADER, wdrażany od początku członkostwa Polski w Unii Europejskiej, przyzwyczaił komentatorów do pozytywnych ocen, uznano go bowiem niemal jednogłośnie za wielki sukces. Rzeczywiście przekonanie o celowości inicjatywy nie budzi wątpliwości, natomiast otwarta zostaje kwestia realizacji programu w warunkach polskiej wsi"" [2011: 34].

Studiując literaturę przedmiotu, można wyróżnić (co najmniej) cztery problemy inspirujące do podejmowania badań dotyczących tego podejścia. Pierwszy stanowią uwarunkowania jego wdrażania. Już w 2006 r. (a więc w pierwszym roku wdrażania PPL+) poruszano kwestię specyfiki wiejskiego sektora NGO i jej konsekwencje dla zaangażowania organizacji pozarządowych w proces tworzenia LGD. Podnoszono problem postaw przedsiębiorców i ich niewielkiego zainteresowania inicjatywami, które nie przynoszą zysku finansowego. Wskazywano na trudne relacje pomiędzy nimi a władzami lokalnymi. Rozważano skutki niskiego poziomu

${ }^{1}$ R. Kamiński, komentując pierwszy etap realizacji podejścia w Polsce, przytacza opinię jednego z ekspertów pracujących w Brukseli, który stwierdził: „Jeśli chodzi o LEADER-a - to dziś nie wypada być przeciw. Wszelkie studia i oceny wskazują, że program ten przyniósł same pozytywy. Politycznie «inncorect» byłoby kontestowanie zasad LEADER-a - także i dla nas ważne jest bottom-up, territorial approach, networking, innovation, multisectoral approach itp." [Kamiński 2008: 110-111]. 
zaufania społecznego mieszkańców wsi dla procesu tworzenia partnerstw terytorialnych [Hanke 2006, Hanke, Psyk-Piotrowska 2006, Furmankiewicz 2006]. W kolejnych latach prowadzono badania nad związkiem aktywności społecznej mieszkańców wsi a ich zaangażowaniem w proces tworzenia partnerstw terytorialnych. R. Śpiewak, analizując cechy wszystkich gmin wchodzących w skład partnerstw w PPL+, stwierdziła zależność między aktywnością ich mieszkańców (mierzoną frekwencją w wyborach prezydenckich, średnią liczbą organizacji pozarządowych oraz średnią liczbą OSP), a powstaniem LGD [Śpiewak 2009: 74-78]. Podobną zależność (w odniesieniu do Dolnego Śląska) zauważyli M. Furmankiewicz i K. Janc ${ }^{2}$ (posługując się zmienną: średnia liczba organizacji pozarządowych) [2011: 116]. M. Halamska (uwzględniając w badaniach takie zmienne, jak: liczba organizacji i stowarzyszeń pozarządowych, frekwencja w wyborach do Sejmu, frekwencja w wyborach samorządowych, kwota uzyskana w ramach akcji WOŚP) wykazała, że na obszarze województwa łódzkiego taki związek nie zachodzi, a powstawanie LGD jest (w tym przypadku) raczej przedsięwzięciem niewielkich grup liderów, a nie efektem mobilizacji wiejskich społeczności ${ }^{3}$ [2009: 15, 21].

Drugi problem podejmowany w polskich badaniach dotyczy wpływu podejścia LEADER na sposób (trajektorię) wykorzystania zasobów lokalnych wsi. S. Michalska i K. Zajda (prowadząc badania na obszarze dwóch LGD) podkreśliły infrastrukturalny wymiar projektów realizowanych za pomocą osi LEADER. Wskazały, że w okresie 2007-2013 rolą tych partnerstw jest raczej walka z deficytami wyposażenia wsi (przykład chodników, placów zabaw, doposażenia organizacji pozarządowych $\mathrm{w}$ stroje $\mathrm{i}$ instrumenty muzyczne), a nie działanie na rzecz innowacyjnego wykorzystania lokalnych zasobów [2011].

Trzecim z podejmowanych problemów badawczych jest wpływ LEADER-a na społeczno-gospodarczy rozwój wsi. Tu stawia się dwa pytania:

1) Czy jest on wdrażany, przede wszystkim na obszarach bardziej zasobnych w różne kapitały (ekonomiczny, ludzki i społeczny), a jeśli tak, czy jego wdrażanie będzie pogłębiało (czy niwelowało) zróżnicowanie polskiej wsi? R. Śpiewak zauważa, że w PPL+ brały udział głównie gminy o przeciętnych wskaźnikach rozwoju gospodarczego ${ }^{4}$, ale jednocześnie podkreśla, iż: „Bez dalszych, pogłębionych i bardziej szczegółowych badań nie jest uprawnione jednoznaczne orzeczenie, że programem w mniejszym stopniu są zainteresowane gminy najsłabiej rozwinięte pod względem społeczno-gospodarczym" [2009: 74-83];

${ }^{2}$ W przypadku gmin, które weszły w skład LGD aktywność w organizacjach pozarządowych była wyższa niż w pozostałych (tj. tych, które były uprawnione do wdrożenia podejścia LEADER, ale w okresie PPL+ nie skorzystały z możliwości jego wdrożenia) [Furmankiewicz, Janc 2011: 1-16].

${ }^{3}$ Autorka sformułowała wnioski, korzystając z badań przeprowadzonych na obszarze województw łódzkiego przez P. Starostę i M. Frykowskiego.

${ }^{4}$ Wnioski zostały sformułowane przy wykorzystaniu typologii społeczno-gospodarczego rozwoju gmin autorstwa A. Rosnera [Śpiewak 2009: 81-82]. 
2) Czy i w jaki sposób podejście LEADER oddziałuje na rozwój wiejskiej przedsiębiorczości? M. Furmankiewicz i K. Janc (na obszarze Dolnego Śląska) zauważyli wpływ PPL+ na tworzenie produktów lokalnych. Konsekwencją ich rejestracji był wzrost dochodów z ich sprzedaży [2011: 119-120]. K. Zajda (analizując wybrane przykłady LGD z województwa łódzkiego) uwypukliła z kolei problemy związane $z$ definiowaniem i wdrażaniem innowacji przez te organizacje oraz przedsiębiorców (korzystających ze wsparcia w ramach działania „Tworzenie i rozwój mikroprzedsiębiorstw”) [Zajda, Dzikowska 2012, Zajda 2013].

Ostatni z ważnych problemów poruszanych przez polskich badaczy, w związ$\mathrm{ku}$ z realizacją podejścia LEADER, dotyczy jego oddziaływania na potencjał kapitału społecznego mieszkańców wsi, czy (w węższym zakresie) potencjał współpracy reprezentantów trzech sektorów (wchodzących w skład lokalnych grup działania). Celem niniejszego opracowania jest zwrócenie uwagi na zawarte w pracach konkluzje, które dotyczą cech LGD oddziałujących na potencjał ich kapitału społecznego. W szczególności będą do nich należeć zagadnienia: 1) wpływu procedur implementacji podejścia LEADER na strukturę LGD oraz relacje między ich członkami (w tym problem municypalizacji czy kolonizacji tych organizacji przez władze lokalne); 2) cech strukturalnych LGD związanych z: a) ich wielkością (liczba członków), b) funkcjonowaniem kluczowych organów: zarządu, rady oraz biura (komórki organizacyjnej), c) granicami terytorium, które obejmują wsparciem, d) stopniem ich profesjonalizacji i ekonomizacji. W analizie nie będą poruszone szczegółowe kwestie dotyczące różnorodnych definicji kapitału społecznego (uwagi o możliwych jego konceptualizacjach czytelnik odnajdzie w części metodologicznej pracy).

Nie przypominając zbyt wielu szczegółów (opisywanych wielokrotnie w literaturze) związanych z zasadami realizacji Pilotażowego Programu LEADER+ [Kamiński, Kwatera 2005, Futymski, Kamiński 2008, Knieć, Hałasiewicz 2008, Hanke, Psyk-Piotrowska 2009, Żolik 2010] oraz osi 4 PROW 2007-2013 [Halamska, Michalska, Śpiewak 2010, Zajda 2011a], należy zwrócić uwagę na kwestie proceduralne, istotne dla struktury lokalnych grup działania i relacji między ich członkami.

Pierwszą z nich jest sposób finansowania schematu I PPL+. Jego beneficjentem mogły zostać organizacje pozarządowe i samorządy gmin. Podmiot aplikujący o wsparcie (zgodnie z zasadą refinansowania) był zobligowany do zabezpieczenia środków na jego realizację. Niski potencjał finansowy wiejskich NGO można traktować jako jedną ze zmiennych wyjaśniających dużą aktywność jednostek samorządu terytorialnego w zakresie składania wniosków do FAPA (na 249 wniosków 153 pochodziło z sektora publicznego ${ }^{5}$ ) [Borek i in. 2006: 42, Halamska, Michalska, Śpiewak 2010: 107]. W czasie wdrażania schematu II (gdzie aplikującym o wsparcie były już LGD) to samorządy najczęściej poręczały kredyty tym nowo powstałym organizacjom.

5 Podpisano 178 umów, z czego zrealizowano 167. 
Drugą z kwestii istotnych dla kształtowania struktury LGD była regulacja dotycząca udziału reprezentantów sektora publicznego w organie zarządzającym LGD (nie większego niż 50\%). Stanowiła ona przedmiot oceny LGD już na etapie aplikowania o środki ze schematu II PPL+. Jednocześnie doświadczenie członków zarządu w zakresie realizacji projektów poświęconych rozwojowi wsi było kryterium oceny potencjału administracyjnego tych organizacji (decydującym o przyznaniu jej środków na realizację schematu II PPL+). Sektor publiczny nie mógł oficjalnie dominować w składzie zarządu, jednak najczęściej to jego reprezentanci cechowali się doświadczeniem i kompetencjami ułatwiającymi praktyczne wdrożenie tego programu. Powyższe uwarunkowania znacząco wpływały na składy zarządów (stanowiąc jedną ze zmiennych wyjaśniających dla zjawiska ukrywania się pod szyldem NGO reprezentantów sektora publicznego).

Dla funkcjonowania LGD ważny jest również wymóg (wprowadzony zgodnie z art. 15 ustawy z dnia 7 marca 2007 r. o rozwoju obszarów wiejskich ze środków Europejskiego Funduszu Rozwoju) powołania w ich ramach organu doradczego - rady ${ }^{6}$. Decyduje ona m.in. o podziale środków między lokalne organizacje pozarządowe (ubiegające się o wsparcie z działania „Małe projekty”), przedsiębiorców (aplikujących o środki np. z działania „Tworzenie i rozwój mikroprzedsiębiorstw”) czy jednostki administracji publicznej i związki wyznaniowe (zainteresowane działaniem „Odnowa wsi”). Uczestnictwo w niej cechuje spory zasób władzy, w konsekwencji skład tych organów czasami bywa równie iluzoryczny jak skład zarządów. A zatem m.in. procedury realizacji PPL+ sprawiły, że władza lokalna stała się głównym rozgrywającym na polu aktywności ukierunkowanej na wdrożenie podejścia LEADER. Możliwe do pozyskania środki stymulowały jej działania ${ }^{7}$. W związku z tym w Polsce dość wcześnie zauważono, że proces tworzenia partnerstw (podobnie jak w innych krajach UE) nie będzie klasycznym przykładem samoorganizacji mieszkańców wsi.

Zjawisko określane mianem municypalizacji czy kolonizacji LGD przez władze lokalne ma wiele wymiarów. Pierwszym jest ich nadmierny wpływ na konstrukcję dokumentów strategicznych dla LGD - zintegrowanych strategii rozwoju obszarów wiejskich, później lokalnych strategii rozwoju. U jego podstaw leżało przekonanie, że funkcjonowanie tych organizacji może przyczynić się do pozyskania dodatkowych środków na projekty w poszczególnych gminach, np. na tworzenie dokumentacji inwestycyjnej. Skutkiem tego w niektórych partnerstwach zaobserwowano zastępowanie (czy uzupełnianie) propozycji dotyczących celów, priorytetów rozwoju partnerstw zgłaszanych przez ich mieszkańców - re-

${ }^{6} \mathrm{~W}$ tym samym akcie prawnym wprowadzono kolejną regulację istotną dla struktury LGD - możliwość członkostwa w nich (w charakterze członka zwyczajnego) osób prawnych (np. samorządów gmin) [por. Halamska, Michalska, Śpiewak 2010: 111].

${ }^{7}$ Choć należy odnotować, że geneza niektórych polskich LGD sięga okresu przedakcesyjnego - tutaj najszerzej komentowanym przykładem są partnerstwa: Dolina Strugu oraz Krzemienny Krąg. 
komendacjami przedstawicieli jednostek samorządu terytorialnego [Furmankiewicz, Królikowska 2010: 86].

Drugim wymiarem kolonizacji LGD przez władze lokalne jest sposób podejmowania decyzji dotyczących alokowania pozyskanych środków. W niektórych partnerstwach o ich przydzielaniu decydują układy towarzyskie władzy lokalnej z wybranymi członkami zarządu [Knieć 2007: 18-19]. Ponadto nieformalne porozumienia między władzami lokalnymi gmin stanowią podstawę ustalania wysokości środków możliwych do pozyskania w konkursach, np. z działania „Odnowa wsi” (uzgodnienia określają, ile projektów z danej gminy w konkretnym konkursie będzie mogło uzyskać wsparcie) [por. LEADER 2011: 34]. Dodatkowo zdarza się, że władza lokalna dokonuje drenażu elity partnerstwa - do struktur samorządowych przechodzą szczególnie kompetentni ich członkowie [Knieć 2010: 65]. $\mathrm{Z}$ drugiej strony praca w biurach LGD (zwłaszcza na obszarze partnerstw, gdzie występuje wysokie bezrobocie) staje się bardzo intratna. W konsekwencji kierownikiem biura czy pracownikiem ds. promocji LGD zostaje osoba z bliskiego otoczenia wójtów i burmistrzów. Tego rodzaju działania doprowadzają do centralizacji przepływu zasobów w sieci. Innymi słowy, o ich dystrybucji decyduje władza lokalna, co skutkuje pogłębianiem ich hierarchizacji [por. Hanke 2009, Furmankiewicz, Królikowska 2010: 21].

Ostatnim w wymiarów procesu municypalizacji LGD jest ich „uspołecznienie", rozumiane jako znaczący udział w ich składzie osób fizycznych reprezentujących sektor społeczny. Są to często osoby faktycznie reprezentujące sektor publiczny, dla których zabrakło miejsca w gorsecie stworzonym przez odgórnie narzucone regulacje [por. Knieć 2010: 5]. Jak zauważają M. Halamska, S. Michalska i R. Śpiewak, w polskich partnerstwach często ma miejsce swoista ekwilibrystyka. Będąc sekretarzem gminy, można być delegowanym do rady LGD z ramienia klubu sportowego, a będąc członkiem rady gminy stać się reprezentantem sektora gospodarczego w wyniku delegacji przez gospodarstwo rolne żony [Halamska, Michalska, Śpiewak 2011: 112].

Municypalizacja LGD stawia pod znakiem zapytania możliwość realizacji przez nie zasady partnerstwa. Przewiduje ona współpracę reprezentantów trzech sektorów, w tym gospodarczego i społecznego. Problemem LGD jest jednak nie tylko to zjawisko, lecz także deficyt przedsiębiorców zainteresowanych podejmowaniem w nich aktywności. Lokalny biznes w małym stopniu uczestniczył w przygotowywaniu ZSROW i LSR, a jego przedstawiciele stoją na czele zarządu tylko w 9\% polskich LGD [Raport PSDB 2012: 6, 45]. K. Zajda (na przykładzie łódzkich LGD) zwróciła uwagę na problem relatywnie niskiego poziomu zaufania, jakim są obdarzani członkowie LGD reprezentujący ten sektor [por. Zajda 2011a: 130]. M. Furmankiewicz i K. Królikowska poruszyli z kolei kwestię ich wizerunku (mieszkańcy wsi nie postrzegają przedsiębiorców jako liderów zdolnych do koordynowania działań lokalnych) [2010: 162]. 
LGD zrzeszają różną liczbę reprezentantów trzech sektorów. Przynależą oni do jednego z organów: zarządu, rady, komisji rewizyjnej lub tworzą zbiorowość członków zwyczajnych. W badaniach prowadzonych w Polsce podkreśla się, że wielkość sieci (jej rozpiętość) pozostaje w związku z aktywnością, którą mogą się wykazać jej członkowie oraz poziomem ich zintegrowania. K. Zajda (analizując przykład łódzkich partnerstw realizujących schemat II PPL+) stwierdziła, że styczności społeczne w LGD zachodzą głównie między osobami zaangażowanymi w prace organu zarządzającego oraz decyzyjnego. Uprzywilejowaną (w tym względzie) jednostką jest również tzw. biuro - komórka organizacyjna, w której skład wchodzą pracownicy najemni [2011a: 150]. Znacząca dla aktywności członków LGD jest więc nie tyle (czasami zafałszowana) przynależność do określonego sektora, ile pełnienie jakiejś funkcji we wspomnianych organach [Zajda 2011b: 141-142]. Badania M. Halamskiej (przeprowadzone w dwóch celowo dobranych LGD) dowodzą z kolei, że nawet tak relatywnie niewielkie struktury jak zarząd i rada (liczące od kilku do kilkunastu osób) mogą być słabo zintegrowane (o czym świadczy fakt, że niektórzy ich członkowie nie znają się między sobą i nie chcą razem współpracować) [Halamska 2011: 120] ${ }^{8}$.

Aktywność w LGD osób, które nie pełnią żadnej funkcji jest ograniczona również przez wysoki poziom profesjonalizacji i ekonomizacji tych organizacji. Wzmacnia on zapotrzebowanie na działania najbardziej kompetentnych członków/partnerów9. Pozyskiwanie oraz wydatkowanie środków finansowych liczonych (w okresie 2007-2013) w milionach złotych wymaga ogromnego wysiłku, tym bardziej, że (co podkreśla R. Kamiński) instytucje wdrażające, zasłaniając się rozporządzeniami unijnymi i tzw. zasadą racjonalności kosztowej, weryfikują każdy koszt (skutkiem czego organizacja lokalnego festynu najczęściej rozpoczyna się od zbierania ofert na dostarczenie napojów gazowanych przynajmniej od przedsiębiorców z terenu całego regionu). Rozbudowana biurokracja trwoni entuzjazm mieszkańców wsi, zaufanie do różnego rodzaju urzędów oraz instytucji UE [Kamiński 2011: 81]. Jednocześnie wywołuje paraliżujący strach związany z kolejną kontrolą. Oddziałuje on negatywnie na możliwość zaangażowania we wdrażane projekty osób, które nie są świadome wszystkich uwarunkowań związanych z realizacją podejścia LEADER. W konsekwencji wysoki poziom skomplikowania procedur ogranicza spontaniczny, oddolny charakter udziału w projektach społeczności lokalnej (w charakterze osób nimi zarządzających, a nie osób odpowiedzialnych jedynie za przystrojenie sali), a LGD coraz chętniej posiłkują się ekspertami, których praca gwarantuje poprawne rozliczenie uzyskanych środków

${ }^{8}$ W badanych LGD autorka wyróżniła subzbiorowości: a) osób nieznanych i marginalizowanych (tj. tych, które nie były wymieniane przez jej członków, jako pożądani partnerzy współpracy) oraz b) osób wykluczanych (wymienianych jako osoby, z którymi nie chce się współpracować).

${ }^{9}$ Ponad trzy czwarte LGD ubiegało się o środki z innych źródeł niż Program Rozwoju Obszarów Wiejskich. Dwie trzecie starało się o nie najwyżej 6 razy. Pozostali byli bardziej aktywni i wysyłali ponad 7 wniosków o wsparcie działań ze środków z innych źródeł (rekordzista wśród LGD wystosował aż 40 wniosków) [Raport PSDB 2012: 60]. 
[por. Furmankiewicz, Królikowska 2010: 51]. A zatem, prowadzone w Polsce badania (choć nie opierają się na próbie reprezentatywnej) zdają się dowodzić, że wielkość struktur i specyfika pracy w LGD (wyznaczona m.in. wysokim poziomem ich profesjonalizacji i ekonomizacji) ograniczają potencjał ich kapitału społecznego [Zajda 2011b: 144].

Lokalne grupy działania funkcjonują na rzecz obszaru partnerstwa, w którego skład wchodzi od jednej do kilkunastu gmin. W literaturze można odnaleźć sprzeczne opinie dotyczące zależności między jego wielkością a aktywnością członków LGD. Z jednej strony podkreśla się, że trudniej im aktywizować 100 czy 150 tys. mieszkańców wsi wskazując, iż ważną (jeśli nie najważniejszą) podstawą integracji wiejskich społeczności lokalnych jest nadal terytorium (utożsamiane nie z przestrzenią, lecz ze swoim i dobrze znanym miejscem $)^{10}$ [por. Halamska 2011: 109-115]. M. Wieruszewska zauważa:

Wraz z powiększaniem się zbiorowości trudniejsze do określania stają się cechy specyficzne grupy. Dzieje się tak dlatego, ponieważ słabną powiązania kulturowego systemu przedmiotowego, jak powiedziałby Znaniecki - rozluźnia się kontekst kultury, tracąc swoją spoistość na korzyść elementów luźno ze sobą powiązanych i niezorganizowanych wokół wartości ważnych dla grupy [2011: 55-56].

W związku z powyższym, proponuje się ograniczenie obszaru partnerstw do 3-5 gmin (zamieszkiwanych - w sumie - przez nie więcej niż kilkadziesiąt tysięcy osób) [Furmankiewicz 2006: 180, Goszczyński 2009: 22-23]. Z drugiej strony podkreśla się, że większe partnerstwa, to jest takie, w których skład wchodzi większa liczba gmin lub gminy o większej gęstości zaludnienia pozyskują więcej środków na działalność (ich wysokość zależy od liczby ich mieszkańców i przypisanych do różnych działań przeliczników ${ }^{11}$ ). Większy budżet zwiększa liczbę działań podejmowanych przez LGD. Dla przykładu w raporcie podsumowującym realizację podejścia LEADER w okresie 2007-2013 (przygotowanym na zlecenie MRiRW) stwierdza się:

LGD większe (tzn. działające na terenie obejmującym najlepiej powyżej 75000 mieszkańców, ale jako minimum można przyjąć około 50 000), dysponujące większym budżetem (powyżej 2 milionów złotych), zwiększające liczbę partnerów zdecydowanie lepiej aktywizują społeczność lokalną, są skuteczniejsze w realizowaniu swoich zadań, w większym stopniu realizują zasadę partnerstwa [Raport PSDB 2012: 4].

${ }^{10}$ M. Halamska (analizując 2 celowo wybrane LGD) wyróżniła 3 podstawy integracji członków ich zarządów i rad: 1) strukturalną (współpraca zachodzi między członkami zarządu lub między członkami rady), 2) statusową (najczęściej współpracują osoby pełniące podobne funkcje poza strukturami LGD - np. wójtowie oraz 3) terytorialną (najlepiej znają się osoby pochodzące z tej samej gminy) [2011: 109-115].

${ }^{11}$ Na realizację lokalnej strategii rozwoju LGD miała do dyspozycji kwotę stanowiąca iloczyn liczby mieszkańców i stawki 116 zł. Ponadto LGD mogły uzyskać 29 zł/mieszkańca na koszty funkcjonowania i 3 zł/mieszkańca na projekty współpracy [Oś 4 PROW... 2009: 25]. 
Należy jednak odnotować, że zastosowana w tych badaniach konstrukcja indeksu skuteczności LGD budzi wątpliwości. Jeśli bowiem przyjmujemy, iż o jego poziomie świadczą wartości takich zmiennych, jak liczba przeprowadzonych naborów i liczba przyjętych wniosków (które są pochodną wielkości budżetu LGD), to nie dziwi fakt, że większe struktury wypadają lepiej ${ }^{12}$. W związku z tym wyprowadzony wniosek nie jest uzasadniony. Tymczasem na jego podstawie rekomenduje się przyłączanie najmniejszych LGD do większych struktur (nie rozważając problemu specyfiki pracy na rzecz mieszkańców wsi, której bardzo często nie można wykonać zza biurka) $)^{13}$.

W kontekście nowego okresu programowania dyskutuje się nad kompetencjami, zadaniami LGD, jak również innymi kwestiami istotnymi dla ich funkcjonowania. Debaty odbywają się najczęściej w czasie spotkań sieci LGD, konferencji organizowanych przez urzędy marszałkowskie czy MRiRW ${ }^{14}$. Postuluje się przede wszystkim ułatwienia natury proceduralnej i finansowej, które mają stanowić odpowiedź na takie problemy LGD, jak: nadmiernie rozbudowana biurokratyzacja działań i kontaktów z urzędami marszałkowskimi, jednostkami Agencji Restrukturyzacji i Modernizacji Rolnictwa, długi czas rozpatrywania wniosków przez te instytucje ${ }^{15}$, brak środków na prefinansowanie projektów, wielomiesięczne

${ }^{12}$ Indeks skuteczności LGD skonstruowano, posługując się takimi zmiennymi, jak: data pierwszego naboru projektów, liczba naborów, liczba projektów współpracy, liczba wniosków przyjętych, środki z innych źródeł, monitorowanie i ewaluacja, liczba zrealizowanych zadań, liczba uczestników zadań [Raport PSDB 2012: 135-136].

${ }^{13}$ W raporcie postuluje się, że małe LGD mogłyby otrzymać okres przejściowy, pozwalający na powiększenie obszaru, na którym działają (poprzez rozszerzenie lub połączenie z innym LGD). Po jego zakończeniu (jeśli nie spełniłyby warunku) byłyby likwidowane [Raport PSDB 2012: 74]. Podobną rekomendację zawarła w swym raporcie Fundacja Wspomagania Wsi, stwierdzając, że „LGD powinny zwrócić szczególną uwagę na możliwość zwiększenia obszarów swojego działania poprzez połączenia czy fuzje. Wydaje się, że liczba LGD w Polsce jest zbyt duża" [LEADER ... 2011: 41].

14 Do najważniejszych, zorganizowanych w 2011 r., należały: a) konferencja pt. Podejście LEADER po 2013 r. wobec nowych wyzwań dla rozwoju obszarów wiejskich Europy (4.10-5.10.2011 r.) [zob. http://www.leaderafter 2013.eu]; b) spotkanie robocze poświęcone przyszłości lokalnych grup działania zorganizowane przez Ministerstwo Rolnictwa i Rozwoju Wsi, Małopolską Sieć LGD oraz Sekretariat Regionalny KSOW Województwa Małopolskiego (12.05-13.05.2011 r.) [zob. http:// www.lgd.malopolska.pl/pliki/podsumowanie\%20spotkania\%2012-13\%20maj.pdf] oraz c) debata pt. LEADER - czy można lepiej, zainicjowana przez Fundację Wspomagania Wsi (17.03.2011 r.) [zob. http://www.fundacjawspomaganiawsi.pl/index.php/component/k2/item/49-raport-leader].

15 Do tych problemów zalicza się również przekraczanie przez urzędy marszałkowskie terminów weryfikacji wniosków, wysokie koszty ich przygotowania (związane z ich obszernością i zdobywaniem różnego rodzaju zaświadczeń), deficyty wiedzy urzędników na temat podejścia LEADER skutkujące żądaniem (od lokalnych grup działania i beneficjentów ostatecznych wsparcia z PROW) bardzo szczegółowych wyjaśnień w każdej sprawie budzącej wątpliwości, konieczność dostarczenia wszystkich dokumentów osobiście przez reprezentantów LGD, nawet w przypadku poprawek wniosków czy dostarczania faktur [LEADER ... 2011: 31-32]. 
opóźnienia w wypłatach pieniędzy ${ }^{16}$, brak środków na zatrudnianie lepiej wykwalifikowanego personelu. Ponadto proponuje się zwiększenie uprawnień LGD (w zakresie oceny wniosków i ich wdrażania), a więc zwiększenie poziomu ich profesjonalizacji. Dla przykładu, w sprawozdaniu ze spotkania roboczego poświęconego przyszłości podejścia LEADER oraz problemów zidentyfikowanych na etapie wdrażania osi IV PROW 2007-2013 (zorganizowanego z inicjatywy MRiRW, Sekretariatu Regionalnego KSOW Województwa Małopolskiego oraz Małopolskiej Sieci LGD) czytamy:

Należy dążyć do zwiększenia kompetencji LGD - kompetencje LGD w zakresie oceny formalnej, podpisywania umów, płatności i kontroli powinny być większe niż dotychczas (idea grantu globalnego poparta przez większość województw). Należy się zastanowić nad przyjęciem przez LGD różnego zakresu kompetencji w zależności od potencjału osobowego i materialnego, wprowadzenie takiej zmiany będzie się wiązać z większą odpowiedzialnością za dystrybucję środków [Podsumowanie 2012b: 3].

W katalogu propozycji dotyczących usprawnienia (w przyszłym okresie programowania) wdrażania podejścia LEADER w Polsce brakuje tych, które dotyczyłyby cech LGD ograniczających poziom ich kapitału społecznego. Może to wynikać co najmniej z dwóch przyczyn.

Po pierwsze, LGD (jak i ich instytucjonalne otoczenie) nie są ich świadome. W połowie przypadków te organizacje nie realizują żadnych badań poświęconych efektywności swojego funkcjonowania. W niedostateczny sposób diagnozują potrzeby, tak mieszkańców partnerstw, jak i swoich członków (średnio polskie LGD przeprowadziły najwyżej po dwa szkolenia kadry realizującej program oraz lokalnych liderów) [Raport PSDB 2012: 5]. Można więc założyć, że LGD (a w zasadzie ich liderzy) nie dysponują obiektywnymi danymi na temat jakości funkcjonowania swojej sieci i konsekwencji dla efektywności działań podejmowanych na rzecz rozwoju wsi.

Po drugie, wyniki dotychczas prowadzonych badań być może nie są dość przekonujące dla członków LGD oraz wszelkich podmiotów związanych z wdrażaniem podejścia LEADER - najczęściej są to studia przypadków, które nie pozwalają na uogólnienie wniosków na całą zbiorowość ${ }^{17}$. Brakuje prac prowadzonych na większych próbach oraz prac całościowo ujmujących problem kapitału społecznego lokalnych grup działania, tj. takich, w których jego poziom byłby określony przy uwzględnieniu nie tylko zmiennych komponentu sieci.

Mając na uwadze te dwie przyczyny, warto podjąć badania dotyczące struktury i uwarunkowań kapitału społecznego polskich lokalnych grup działania. Ich celem powinna być odpowiedź na pytanie o ich prawdziwe oblicze. Czy są

${ }^{16}$ Do problemów finansowych funkcjonowania LGD zalicza się również: wysokie koszty pożyczek zaciąganych w instytucjach finansowych, które nie są kosztem kwalifikowanym w projektach, a więc nie podlegają refundacji [LEADER... 2011: 32].

${ }_{17}$ Zupełnie innym problemem jest promocja ich wyników i zainteresowanie świata praktyków badaniami akademickimi. 
to organizacje pozarządowe, w których należy upatrywać szczególnej szansy wzrostu poziomu kapitału społecznego mieszkańców wsi? Czy są to specyficzne agencje rozwoju lokalnego, funkcjonujące pod szyldem trzeciego sektora? A może raczej są to organizacje hybrydowe, które skupiają podmioty z trzech sektorów, tworzące „sieci współpracy”? Ponadto takie badania pozwolą także na zabranie głosu w dyskusji związanej z istotą kapitału społecznego. Zgodnie z postulatem socjologii refleksyjnej, analizując relatywnie nową (związaną z implementacją podejścia LEADER) rzeczywistość społeczną wsi, można dokonać weryfikacji przyjętych założeń dotyczących specyfiki, cech i komponentów kapitału społecznego [zob. Bukraba-Rylska 2011: 28].

\subsection{Założenia metodologiczne badań własnych}

\subsubsection{Podstawy teoretyczne podejmowanych badań}

Podejmując badania nad kapitałem społecznym lokalnych grup działania, zastanawiano się nad możliwą do zastosowania jego definicją. Wybrano tę autorstwa R. Putnama - uważaną za najbardziej złożoną i w największym stopniu ukazującą różne jego oblicza. Celem niniejszego rozdziału jest, po pierwsze, jej krótkie scharakteryzowanie. Interesować nas będą wyszczególnione przez tego autora komponenty kapitału społecznego, jego wymiary oraz dysponenci. Po drugie, analizie zostaną poddane niektóre z korelatów tak rozumianego kapitału społecznego, ważne $\mathrm{z}$ uwagi na obrany przedmiot zainteresowania, tj. specyfika aktywności społecznej mieszkańców wsi, usytuowanie obszarów wiejskich $\mathrm{w}$ różnych regionach kraju oraz poziom ich rozwoju gospodarczego.

Zgodnie z ujęciem R. Putnama:

Kapitał społeczny odnosi się do takich cech organizacji społeczeństwa jak zaufanie, normy i powiązania, które mogą zwiększyć sprawność społeczeństwa ułatwiając skoordynowane dzialania [1995: 258].

Trzy (wyszczególnione w definicji) zmienne składowe są współzależne - zaufanie, normy i sieci powiązań wzmacniają i kumulują się [Putnam 1995: 276]. Ludzie, którzy ufają innym współobywatelom, częściej podejmują się pracy wolontaryjnej, włączają się w politykę i działanie organizacji lokalnych, więcej wpłacają na cele charytatywne [Putnam 2008: 230-231]. Normy i wartości, zinternalizowane przez członków społeczeństwa, wpływają na poziom ich zaufania społecznego. Sprzyjają mu zwłaszcza: norma uogólnionej wzajemności ${ }^{18}$, prawdomówności, solidarności, podmiotowości [Putnam 1995: 264-265].

${ }^{18}$ Oznacza ona, że jednostka działa, nie oczekując od partnera interakcji - przyjmuje, iż w nieokreślonej przyszłości ktoś inny może udzielić jej pomocy [Putnam 2008: 7]. 
Kapitał społeczny ma wiele twarzy, które R. Putnam utożsamia z jego dwoma wymiarami określanymi jako bonding social capital (kapitał wiążący) oraz bridging social capital (kapitał pomostowy). Różnią się one poszczególnymi cechami. Dla pierwszego z nich znamienna jest ekskluzywna, zamknięta sieć społeczna, ukierunkowana na potrzeby, interesy jej członków, silna solidarność wewnątrzgrupowa (nieznajdująca odzwierciedlenia w postawach w stosunku do zewnętrznych aktorów społecznych), wysoki poziom zaufania członków sieci do osób znanych, ale dużo niższy do nieznajomych [por. Frykowski, Starosta 2008: 43, Frykowski 2009: 67]. Drugi z wyszczególnionych wymiarów przejawia się w otwartych sieciach społecznych, których uczestnicy zinternalizowali normy i wartości sprzyjające kooperacji wewnątrz- i międzygrupowej i którzy cechują się relatywnie wysokim poziomem zaufania do nieznajomych [por. Niesporek 2008: 26].

Zdaniem R. Putnama, formy kapitału społecznego różnią się potencjałem w zakresie oddziaływania na rozwój kapitału wiążącego lub pomostowego. Pisze on:

Spośród wszystkich wymiarów, wedle których różnicują się formy kapitału społecznego, być może najważniejsze jest rozróżnienie na łączące (bridging), czyli inkluzyjne, i spajające (bonding), czyli ekskluzywne. Pewne formy kapitału społecznego są z przypadku lub z konieczności skierowane do wewnątrz i wykazują tendencję do wzmacniania wykluczających tożsamości i homogenicznych grup. Przykłady spajającego kapitału społecznego obejmują etniczne organizacje bratniej pomocy, kościelne grupy czytelnicze kobiet i modne country clubs. Inne sieci są skierowane na zewnątrz i obejmują ludzi z różnych odłamów społecznych (social cleavage). Przykłady łączącego kapitału społecznego obejmują ruchy na rzecz praw obywatelskich, wiele młodzieżowych grup usługowych i ekumeniczne organizacje religijne. [Putnam 2008: 40]

A zatem organizacje pozarządowe częściej będą sprzyjać budowie kapitału pomostowego, zaś grupy interesu - kapitału wiążącego ${ }^{19}$, tym samym mają większe znaczenie dla budowy społeczeństwa obywatelskiego, ponieważ wspierają kooperację z aktorami społecznymi (indywidualnymi i zbiorowymi) o różnych cechach społeczno-demograficznych ${ }^{20}$.

Kapitał społeczny jest dobrem publicznym, jego dysponentem jest zbiorowość. R. Putnam pisze, że „kapitał ten, inaczej niż kapitał konwencjonalny, stanowi zwykle dobro publiczne, a nie prywatne" [1995: 263]. Jednostka może podjąć świadomą decyzję o inwestowaniu we własny kapitał ludzki, obrać za cel podjęcie działań ukierunkowanych na wzrost kompetencji, wiedzy, umiejętności i poddać inwestycję weryfikacji, ale poziom kapitału społecznego jest zależny

${ }^{19}$ Fakt, że organizacje pozarządowe relatywnie częściej są formami kapitału pomostowego, nie oznacza, iż każda z nich jest jego nośnikiem. Przykład stanowią organizacje ekologiczne, odstępujące od protestów po otrzymaniu wysokiej dotacji na realizację tzw. celów statutowych. Innymi słowy, te organizacje, które nie tyle działają na rzecz interesu publicznego (w tym przypadku ochrony środowiska naturalnego), ile interesów swoich członków występujących w charakterze tzw. ekspertów.

20 Zdaniem R. Putnama, kapitał społeczny (zwłaszcza pomostowy) ułatwia rozwiązywanie problemów działania zbiorowego, redukuje koszty codziennych wymian społecznych, zwiększa świadomość o „wzajemnym powiązaniu ludzkich losów”, ułatwia pozyskiwania informacji [2008: 474-476]. 
od wspólnoty, do której należy, postaw akcjonormatywnych jej członków, relacji między nimi, poziomu zaufania, jakim siebie obdarzają [Zajda 2011: 15, 21-22]. Przyjęcie takiego założenia sprawia, że możliwe jest badanie (zgodnie $\mathrm{z}$ terminologią zaproponowaną przez J. Bartkowskiego) dwóch jego aspektów - zbiorowego oraz grupowo-warstwowego. Tak więc analizy mogą dotyczyć: a) poziomu kapitału społecznego, jakim dysponuje zbiorowość; b) zmian tego poziomu; c) różnic w poziomie kapitału społecznego różnych zbiorowości; d) zróżnicowania kapitału społecznego określonej zbiorowości (jego struktury) [Bartkowski 2007: 76, Zajda 2011: 24-26].

Niezależnie od podjętej problematyki, wyzwaniem dla badaczy jest wybór zmiennych cząstkowych kapitału społecznego. R. Putnam w Samotnej grze w kręgle wyszczególnił następujące: 1) zorganizowane życie wspólnotowe ${ }^{21}$,2) zaangażowanie w sprawy publiczne $\left.{ }^{22}, 3\right)$ wolontariat $\left.^{23}, 4\right)$ socjalizację nieformalną ${ }^{24}$, 5) zaufanie społeczne ${ }^{25}$ [2008: 479]. Nie muszą być one przydatne w każdym kontekście kulturowym. Bezrefleksyjne ich kopiowanie jest bezzasadne. J. Herbst podkreśla, że nadal mankamentem polskich badań nad kapitałem społecznym jest nie do końca przemyślany dobór zmiennych, bazujący albo na wzorach zaczerpniętych z literatury zachodniej, albo na kryterium dostępności danych, nie zaś na analizie kontekstu, w którym funkcjonuje dana zbiorowość [J. Herbst 2008: 23-24]. Jak słusznie zauważają P. Sobiesiak-Penszko oraz M. Kotnarowski, kontekst stanowi filtr dla bodźców docierających do jednostki, modyfikuje znaczenie poszczególnych działań, wpływa na postawy, motywacje, struktury poznawcze aktorów indywidualnych i zbiorowych [2012: 54-55].

W rozważaniach dotyczących kapitału społecznego mieszkańców wsi podkreśla się, że częściej jest on wiążący niż pomostowy ze względu na specyfikę więzi rodzinno-sąsiedzkich. Zwłaszcza instytucja sąsiedztwa na wsi ma inne znaczenie niż w dużym mieście, gdzie sąsiadów znamy rzadziej i gdzie nie tak chętnie działamy na ich rzecz ${ }^{26}$. Jednak i na wsi coraz częściej kapitał wiążący „swoich” ulega

${ }^{21}$ Zmienną globalną tworzyły zmienne, takie jak: 1) pełnienie funkcji w organach statutowych lokalnej organizacji w ostatnim roku; 2) pełnienie funkcji w zarządzie klubu lub organizacji w ostatnim roku; 3) organizacje obywatelskie i społeczne na tysiąc mieszkańców; 4) średnia liczba spotkań klubowych odbytych w ciągu ostatniego roku; 5) średnia liczba członków w grupach.

${ }^{22}$ W skład tej zmiennej globalnej wchodziły: frekwencja w wyborach prezydenckich (w 1988 i 1992 r.) oraz uczęszczanie na zebrania publiczne w sprawach miasta lub szkoły w ostatnim roku.

${ }^{23}$ Wolontariat badano, określając: 1) liczbę organizacji typu non-profit na tysiąc mieszkańców;

2) średnią liczbę prac przy projektach wspólnotowych w ostatnim roku; 3) średnią liczbę prac w wolontariacie w ostatnim roku.

${ }^{24}$ Tu R. Putnam zwracał uwagę na odsetek badanych zgadzających się ze stwierdzeniem: „Spędzam mnóstwo czasu na odwiedzaniu znajomych” oraz na średnią liczbę przyjęć urządzonych w domu w ostatnim roku.

${ }^{25} \mathrm{O}$ zaufaniu społecznym respondentów świadczyło to, czy zgadzają się ze stwierdzeniem: „Większości ludzi można ufać” oraz „Większość ludzi jest uczciwa”.

${ }^{26}$ B. Fedyszak-Radziejowska jego poziom (chyba zbyt optymistycznie) określa jako wysoki, dodając, że jego mocną stroną jest wysoka akceptacja norm współpracy i współdziałania (związana 
zmianie, zaczyna łączyć różne środowiska i grupy społeczne [Fedyszak-Radziejowska 2012: 119]. Dzieje się to jednak wolniej niż w społecznościach miejskich. Mieszkańcy wsi nadal działają w strukturach niesformalizowanych, np. kołach gospodyń wiejskich. W badaniach stawia się hipotezę, że istnieje związek między poziomem ich aktywności a historią regionów, które zamieszkują. Przyjmuje się, iż najwyższy poziom aktywności społecznej wykazują mieszkańcy byłego zaboru austriackiego oraz byłego zaboru pruskiego, mniejszy mieszkańcy dawnego zaboru rosyjskiego. Najsłabiej pod tym względem wypadają społeczności terenów zachodnich i północnych ${ }^{27}$ [Peisert, Kontarowski 2012: 257].

Argumentuje się, że Galicja cechowała się względną autonomią od zaborcy, co skutkowało licznymi swobodami politycznymi jej obywateli, ich aktywnością stowarzyszeniową (szczególnie rozwojem ruchu ludowego) ${ }^{28}$. W Wielkopolsce (regionie stosunkowo zamożnym) wcześnie pojawił się ruch stowarzyszeniowy (przeciwdziałający procesowi wynarodowienia) i krzewiący idee pracy u podstaw. W Kongresówce aktywność obywatelska była na niskim poziomie. Tutaj zwalczano wszelkie przejawy polskości. Pauperyzacja społeczeństwa, niski poziom jego edukacji (karano nawet za zakładanie bibliotek) oraz antagonizmy między stanami nie sprzyjały zawiązywaniu zrzeszeń (straże pożarne zaczęły tu powstawać dopiero po 1907 r.). Wizerunek Ziem Zachodnich i Północnych jest trudniejszy do uchwycenia - w literaturze formułuje się sprzeczne sądy na ten temat. Podkreśla się wykorzenienie tamtejszych mieszkańców, ich atomizację społeczną i niski poziom świadomości zbiorowej, ale też wyższy poziom otwartości

z religijnością i przejawiająca się także w aktywności na rzecz parafii) [2012: 123]. Poziom kapitału społecznego mieszkańców wsi analizuje, biorąc pod uwagę ich aktywność na rzecz środowiska lokalnego, udział w wyborach, pozytywny stosunek do demokracji, przynależność do organizacji, pełnienie w niej funkcji społecznych oraz przekonanie, że innym ludziom można ufać [Fedyszak-Radziejowska 2012: 118]. W analizach odwołuje się do badań CBOS z 2012 r. oraz Diagnozy spotecznej 2011.

${ }^{27} \mathrm{~W}$ analizach związku między historią poszczególnych regionów a poziomem kapitału społecznego, jakim dysponują ich mieszkańcy, uwzględnia się ich podziały zgodne z granicami zaborów (po 1795 r.) oraz I Rzeczypospolitej. Dla przypomnienia, ziemie zaboru austriackiego, przyłączone do Polski w latach 1918-1921, współcześnie pokrywają się z obszarem Małopolski i Podkarpacia (oraz południowymi krańcami województwa śląskiego). Ziemie zaboru pruskiego, przyłączone do Polski w latach 1918-1921 i śląski obszar plebiscytowy, to obszary współczesnej Wielkopolski, województwa kujawsko-pomorskiego oraz opolskiego (w mniejszym zakresie pomorskiego - jego część południowa, warmińsko-mazurskiego - jego wschodnie krańce oraz śląskiego - jego część środkowa). Ziemie dawnego zaboru rosyjskiego to współczesne woj. łódzkie, mazowieckie, Podlasie, Lubelszczyzna, świętokrzyskie, a także południowo-wschodnie obrzeża woj. kujawsko-pomorskiego oraz północno-wschodnia część woj. śląskiego. Ziemie Zachodnie i Północne to głównie obszar dzisiejszego Dolnego Śląska i ziemi lubuskiej, woj. zachodniopomorskiego oraz warmińsko-mazurskiego (bez wschodnich krańców). Należą również do niego północne i południowe tereny woj. wielkopolskiego oraz część północna woj. pomorskiego [Olech 2012: 33].

${ }^{28} \mathrm{Z}$ drugiej strony jej poziom rozwoju gospodarczego był stosunkowo niski, zaś antagonizmy między chłopstwem a ziemiaństwem wyjątkowo silne. 
(wymuszony przesiedleniami, potrzebą dostosowania się do nowych warunków), przedsiębiorczości i innowacyjności [Peisert, Kontarowski 2012: 254-257, Działek 2008: 132, Hryniewicz 2006].

Nie zawsze hipoteza o wpływie tradycji historycznych regionu na poziom kapitału społecznego jego mieszkańców ulega konfirmacji. A. Peisert i T. Kontarowski wskazują, że co prawda najwyższy poziom partycypacji obywatelskiej (w wymiarze indywidualnym) cechuje mieszkańców byłej Galicji, ale wartości wskaźników ${ }^{29}$ dla mieszkańców ziem zaboru pruskiego są niskie (podobne jak dla Kongresówki). Na Ziemiach Zachodnich i Północnych mieszkańcy zdecydowanie unikają kandydowania w wyborach lokalnych, relatywnie rzadko głosują, ale ponadprzeciętnie uczestniczą w organizacjach trzeciego sektora i spółdzielniach [Peisert, Kontarowski 2012: 270-271]. A zatem, w opinii autorów, przestrzenny rozkład zmiennych komponentu sieci kapitału społecznego tylko częściowo nawiązuje do historycznych regionów kraju ${ }^{30}$. Podobnego zdania jest również J. Działek ${ }^{31}$, który wykazał, iż najwyższy poziom kapitału społecznego cechuje mieszkańców dolnośląskiego, mazowieckiego, małopolskiego oraz podkarpackiego. Poziom najniższy cechuje mieszkańców łódzkiego, zachodniopomorskiego, lubuskiego, śląskiego i kujawsko-pomorskiego [Działek 2008: 139-141] ${ }^{32}$.

Stosowanie definicji (czy szerzej - ujęcia) kapitału społecznego autorstwa R. Putnama stawia przed badaczami kilka wyzwań. Pierwszym z nich jest ustosunkowanie się do rozbieżności między wynikami prowadzonych przez niego prac

${ }^{29}$ Na aktywność obywatelską składały się dwa wymiany: horyzontalny i wertykalny. W skład horyzontalnego wchodziła: 1) partycypacja indywidualna: działania na rzecz parafii, pomoc w budowie lub remoncie szkoły, domu kultury, świetlicy lub innych tego typu budynków, działania na rzecz ochrony środowiska naturalnego (np. sadzenie drzew, sprzątanie okolicy), upowszechnianie lokalnej historii i tradycji, organizowanie wypoczynku i czasu wolnego mieszkańców gminy (miasta, dzielnicy), np. organizowanie festynów czy pikników, inne działania podejmowanie na rzecz miejscowości i (lub) jej mieszkańców; 2) partycypacja zbiorowa - liczba organizacji pozarządowych. W skład wymiaru wertykalnego wchodziły zmienne, takie jak: partycypacja wyborcza (frekwencja w wyborach na wójta, burmistrza, prezydenta), aktywność obywateli - poszukiwanie informacji na temat decyzji władz [Peisert, Kotnarowski 2012: 258-265].

${ }^{30}$ Autorzy podkreślają złożony charakter zależności między uwarunkowaniami historycznymi regionu a poszczególnymi wymiarami aktywności obywatelskiej. Zaobserwowali dość silny wpływ specyfiki regionu na liczbę form podejmowanej indywidualnej aktywności społecznej (region historyczny wyjaśniał $6 \%$ wariancji zmiennej „liczba form aktywności społecznej”). Nie zaobserwowali natomiast zależności między cechami regionu a liczbą organizacji trzeciego sektora [Peisert, Kotnarowski 2012: 258-261].

${ }^{31}$ Autor badał poziom kapitału społecznego, posługując się czterema zmiennymi: 1) aktywność stowarzyszeniowa mieszkańców regionu, 2) liczba członków organizacji na 100 mieszkańców, 3) gęstość sieci powiązań oraz 4) cechujące ich zaufanie społeczne.

${ }^{32}$ M. Herbst, badając zależność między uwarunkowaniami historycznymi poszczególnych regionów a poziomem ich rozwoju gospodarczego, zaobserwował, że jeśli różnice w zasobach kapitału fizycznego i ludzkiego pozostają pod kontrolą modelu, przynależność do historycznych dzielnic nie ma wpływu na osiągane w latach 1995-2003 tempo wzrostu gospodarczego [M. Herbst 2007: 200]. 
a efektami analiz prowadzonych w Polsce. Nie jest jasny związek między tradycją regionów a kapitałem społecznym ich mieszkańców. Podobnie niejasny jest związek między kapitałem społecznym mieszkańców wsi a poziomem rozwoju gospodarczego obszaru, który zamieszkują. Zgodnie z wnioskami R. Putnama, kapitał społeczny konwertuje w ekonomiczny, w związku z czym w badaniach przyjmuje się, że zmienne te są współzależne. J. Czapiński podkreśla jednak, iż zależność ta obowiązuje głównie w krajach wyżej rozwiniętych, w słabiej ważniejszym wyznacznikiem rozwoju gospodarczego jest kapitał ludzki (mierzony przeciętną liczbą lat nauki mieszkańców) [2011: 286, 290]. M. Herbst konkludując wyniki swoich badań (na temat związku tych dwóch zmiennych) zauważa, że w sytuacji, kiedy kontrolowane są zasoby kapitału ludzkiego i fizycznego, kapitał społeczny nie wpływa na wzrost gospodarczy ${ }^{33}$. Podkreśla jednak: ,zastosowana metoda badania pozwala sformułować wnioski jedynie w stosunku do wąsko zdefiniowanego kapitału społecznego" [M. Herbst 2007: 199-202].

Zastanawiająca jest również relacja między kapitałem społecznym mieszkańców wsi a sprawnością ich instytucji przedstawicielskich. Dla przypomnienia, w książce Demokracja $w$ działaniu R. Putnam udowadniał, że instytucje obecne w północnych regionach Włoch są sprawniejsze niż te z regionów południowych ze względu na wyższy poziom kapitału społecznego, jakim dysponują ich mieszkańcy. Tymczasem aktywność społeczna obywateli nie zawsze współwystępuje z otwartością władz na ich partycypację. A. Olech (prowadząca wraz z zespołem badania nad partycypacją publiczną w Polsce na reprezentatywnej próbie gmin wiejskich, miejsko-wiejskich oraz miejskich) stwierdziła nawet, że zależność między tak określonymi zmiennymi jest negatywna: „Im bardziej władze gminy są nastawione na partycypację, tym mniej w danej gminie funkcjonuje organizacji pozarządowych, szczególnie spółdzielni i stowarzyszeń” [2012: 107-108]. Ponadto A. Sułek zauważa, iż nie jest również oczywisty związek między akceptacją demokracji a aktywnością społeczną obywateli:

Zarówno akceptacja demokracji, jak i doświadczenia i działania zależą od wykształcenia, a związek między nimi jest zasadniczo efektem równoczesnego wpływu wykształcenia. Samodzielny, czysty wpływ akceptacji demokracji jest słaby i niesystematyczny. Przykładowo, jedynie w dolnych grupach wykształcenia ci, którzy bezwzględnie akceptują demokrację mają wyższą wartość indeksu niż badani ze wszystkich pozostałych kategorii. Akceptacja demokracji jako zasady politycznej nie ma istotnego znaczenia dla udziału w życiu obywatelskim na poziomie lokalnym. [2011: 283]

Wbrew twierdzeniom R. Putnama, w badaniach często nie potwierdza się również związku między poszczególnymi komponentami kapitału społecznego. Przykładem są analizy D. Walczak-Duraj, w których zauważa ona zjawisko

${ }^{33}$ Autor, badając poziom kapitału społecznego mieszkańców regionów, wykorzystuje takie zmienne, jak frekwencja wyborcza (odzwierciedlająca zaangażowanie obywateli w sprawy publiczne) oraz liczba fundacji i stowarzyszeń (przypadających na mieszkańca podregionu). 
dekompozycji cech kapitału społecznego, rozumiane jako brak związków między poszczególnymi z nich ${ }^{34}$ [2008: 186]. Podobne wnioski zostały wyprowadzone przez M. Theiss i T. Żukowskiego. Na podstawie badań CBOS z 2008 r. zauważyli oni, że między komponentami kapitału społecznego mieszkańców Polski nie zachodziły zależności lub były one bardzo słabe (m.in. słaba okazała się zależność między zbiorczym wskaźnikiem zaufania a udziałem badanych w społeczeństwie obywatelskim) [Theiss, Żukowski 2008]. Badania autorów Diagnozy społecznej 2011 wykazały z kolei, iż zaufanie podnosi aktywność społeczną tylko w grupie z wykształceniem wyższym, ale lekko obniża w grupie z wykształceniem podstawowym i średnim, nie ma natomiast żadnego znaczenia $\mathrm{w}$ grupie $\mathrm{z}$ wykształceniem zasadniczym zawodowym [Sułek 2011: 283].

Drugim wyzwaniem dla badaczy, stosujących ujęcie kapitału społecznego R. Putnama jest dostrzeżenie jego różnorodności, form powiązanych z kapitałem pomostowym i tych, które sprzyjają kapitałowi wiążącemu. Aktywność społeczna mieszkańców wsi (jako składowa kapitału społecznego) ma bowiem wiele twarzy. Może przybierać postać niesformalizowaną (często trudną do uchwycenia w badaniach, wymykającą się oficjalnym statystykom) i sformalizowaną. Tę z kolei można różnicować na wiele sposobów. Dla przykładu, wśród organizacji pozarządowych można wyszczególnić te, które działają incydentalnie, głównie na rzecz osób (a nie instytucji), bazując na pracy własnych członków i te, które są sprofesjonalizowane w bardzo dużym stopniu - zatrudniają płatny personel, pozyskują dotacje na działalność, liczone w milionach złotych, wspierają nie tylko osoby, lecz także instytucje. Wskazane cechy (jako jedne z wielu) mogą świadczyć o tym, że dana forma aktywności społecznej w większym stopniu wzmacnia kapitał pomostowy niż wiążący (lub odwrotnie). Zweryfikowanie poziomu otwartości sieci (skłonności do włączania nowych członków), określenie relacji między ich członkami, poziomu zaufania, jakim obdarzają siebie nawzajem i osoby spoza sieci pomaga nie tylko odpowiedzieć na powyższe pytanie, ale też zdefiniować zależności zachodzące między jego komponentami, a więc rozstrzygnąć problem kompozycji cech kapitału społecznego.

Niektóre z powyższych kwestii będą analizowane w projekcie badawczym pt. Struktura i uwarunkowania kapitału społecznego lokalnych grup działania. W szczególności interesujące są zależności między poziomem tego kapitału a zmiennymi rozwoju społeczno-gospodarczego partnerstw, na rzecz których funkcjonują oraz problem kompozycji jego cech. Będziemy również dążyć do udzielenia odpowiedzi na pytanie o to, czy te formy kapitału społecznego sprzyjają tworzeniu kapitału pomostowego? W kolejnej części pracy zaprezentujemy metodologię prowadzonych badań oraz odniesiemy się do problemów, które pojawiły się w czasie ich realizacji.

${ }^{34}$ Dekompozycja oznacza rozproszenie zmiennych kapitału społecznego, brak ich spójności, co osłabia siłę oddziaływania jego potencjału [Zajda 2011]. 


\subsubsection{Założone cele i problematyka badania}

Polskie lokalne grupy działania różnicuje wiele cech, np. forma prawna czy wielkość sieci (mierzona liczbą jej członków/partnerów ${ }^{35}$ ). Przyjęto, że szczególnie znacząca dla badania kapitału społecznego tych organizacji jest ich geneza. Wśród LGD można wyróżnić:

- grupy powstałe na skutek realizacji schematu I PPL+, które wdrażały schemat II i obecnie realizują oś 4 PROW 2007-2013;

- grupy powstałe na skutek realizacji schematu I PPL+, które nie wdrażały schematu II, ale obecnie realizują oś 4 PROW 2007-2013;

- grupy powstałe bez związku z realizacją schematu I, które wdrażały schemat II i obecnie realizują oś 4 PROW 2007-2013;

- grupy powstałe bez związku ze schematem I i II PPL+, ale obecnie realizują oś 4 PROW 2007-2013 [zob. Zajda 2011: 95].

Te organizacje, które reprezentują typ pierwszy oraz trzeci, funkcjonują na tyle długo, że można zakładać, iż relacje między ich członkami są względnie ustabilizowane. Pozwala to odnieść się do ich cech, a w szczególności określić powiązania uczestników sieci, zaufanie jakim siebie obdarzają, normy i wartości, którymi kierują się w swoich działaniach.

Realizacji projektu badawczego przyświecały dwa główne cele. Pierwszym było rozpoznanie poziomu i struktury kapitału społecznego lokalnych grup działania, drugim - zdiagnozowanie jego społeczno-ekonomicznych uwarunkowań.

Przyjęto, iż analizowane będą lokalne grupy działania z województw cechujących się najmniejszym i największym nasyceniem tego rodzaju struktur w czasie realizacji schematu II PPL+, w związku z czym trzecim celem podjętych badań było porównanie poziomu i struktury kapitału społecznego LGD, należnych do dwóch zbiorów województw.

W konsekwencji problematyka badań odnosiła się przede wszystkim do struktury kapitału społecznego lokalnych grup działania z województw, na których obszarze istnieje najmniejsza i największa liczba struktur tego typu oraz społeczno-ekonomicznych uwarunkowań poziomu kapitału społecznego lokalnych grup działania $\mathrm{z}$ wymienionych województw, a także uwarunkowań ich funkcjonowania, związanych ze współpracą sektora społecznego, publicznego i gospodarczego, na którego obszarze działają.

Sformułowano 5 hipotez badawczych:

1. Im wyższy poziom aktywności społecznej na obszarze, na rzecz którego funkcjonują lokalne grupy działania, tym wyższy poziom ich kapitału społecznego;

${ }^{35}$ Należy zwrócić uwagę, że dalej w tekście używa się pojęcia „członek” LGD (bo większość tych struktur ma formę prawną stowarzyszenia), mając jednak świadomość, że w przypadku, gdy ma ona formę prawną fundacji, należałoby używać sformułowania „partner”. 
2. Im niższy poziom gospodarczego rozwoju obszaru, na rzecz którego funkcjonują lokalne grupy działania, tym niższy poziom ich kapitału społecznego;

3. Im wyższy poziom współpracy między sektorem społecznym, publicznym i gospodarczym na obszarze, na rzecz którego funkcjonują lokalne grupy działania, tym wyższy ich poziom kapitału społecznego;

4. Kapitał społeczny lokalnych grup działania ma cechy kapitału zdekodowanego, tj. między wszystkimi komponentami tego kapitału nie występują zależności istotne statystycznie;

5. W strukturze kapitału społecznego lokalnych grup działania najniższym poziomem cechuje się komponent sieci.

Zbadanie poziomu i struktury kapitału społecznego lokalnych grup działania wymagało określenia wartości zmiennych przyporządkowanych do jego poszczególnych komponentów. Przedmiotem badania były więc: zaufanie wertykalne i horyzontalne, cechujące członków/partnerów lokalnych grup działania; podzielane przez nich normy i wartości oraz sieć współpracy w ramach LGD.

W ramach komponentu zaufania zwrócono uwagę na takie zmienne, jak:

- zaufanie członków LGD do osób znanych (rodziny, sąsiadów, współpracowników spoza LGD oraz współpracowników z LGD);

- zaufanie społeczne, cechujące członków LGD (przekonanie, że większości ludzi można ufać oraz zaufanie do obcych osób spotykanych w różnych sytuacjach życiowych);

- zaufanie członków LGD do instytucji i organizacji lokalnych (władz lokalnych, organizacji pozarządowych, lokalnych przedsiębiorców).

W ramach komponentu norm i wartości analizowano:

- patriotyzm lokalny członków LGD - więź z gminą zamieszkania, uczestnictwo w ostatnich wyborach samorządowych, gotowość ponoszenia wydatków finansowych na rzecz promowania lokalnej kultury;

- wartości i normy podzielane przez członków LGD - ważną wartością (ze względu na specyfikę LGD) jest partnerstwo, rozumiane jako obszar spójny pod względem przyrodniczym, gospodarczym i kulturowym. Dążono do ustalenia powodów towarzyszących członkostwu w organizacji ${ }^{36}$, badano, czy członkowie (partnerzy LGD) działają na jej rzecz, czy też może kierują się interesami innej grupy społecznej lub interesami osobistymi. Badano również stosunek respondentów do normy współpracy międzysektorowej (weryfikowano, czy są przekonani o tym, że wszyscy członkowie tej organizacji powinni współpracować niezależnie od tego, czy reprezentują sektor społeczny, publiczny czy gospodarczy) oraz po-

\footnotetext{
${ }^{36}$ Respondentom zadano pytanie o to, czy powodem ich uczestnictwa w sieci jest chęć realizacji interesów osobistych lub interesów sektora, który reprezentują, czy też może jest nim chęć działania na rzecz mieszkańców gminy zamieszkania lub mieszkańców wszystkich gmin zrzeszonych w partnerstwie.
} 
ziom ich przekonania o konieczności znajomości procedur funkcjonowania LGD wśród ich członków;

- społecznikostwo badanych - gotowość do niesienia pomocy innym ludziom, chęć kontynuacji członkostwa w LGD (pracy na rzecz dobra wspólnego). Analizowano również poziom poczucia podmiotowości badanych (rozumiany jako przekonanie o posiadaniu kontroli nad własnym życiem).

W ramach komponentu sieci wyróżniono zmienne, takie jak:

- zaangażowanie członków LGD w sieci współpracy na rzecz partnerstwa lub gminy - praca na rzecz mieszkańców gminy (deklaracja oraz poziom aktywności - liczba działań, w które angażował się respondent), uczestnictwo w promowaniu lokalnej kultury;

- uczestnictwo badanych w pracach LGD - ocena ich aktywności w pracach LGD w czasie realizacji schematu II PPL+ (w tym ocena formy ich aktywności w grupie), częstotliwość ich udziału w walnych zebraniach LGD, przepływ informacji o spotkaniach grupy ${ }^{37}$ wśród członków LGD, rodzaje spotkań, najważniejsze ze zrealizowanych projektów $w^{38}$;

- poczucie wpływu członków LGD na funkcjonowanie partnerstwa - partycypacja członków LGD w procesach decyzyjnych grupy ${ }^{39}$, wyszczególnienie elementów sieci w największym stopniu zaangażowanych w prace grupy ${ }^{40}$, przekonanie badanych o wpływie działań LGD na rozwój partnerstwa [zob. Zajda 2010].

Do uwarunkowań sfery społecznej kapitału społecznego lokalnych grup działania zaliczono:

- liczbę aktywnych KGW i innych tradycyjnych form współpracy mieszkańców wsi (np. OSP) na obszarze partnerstw w 2010 r.;

${ }^{37}$ Respondentów pytano o to, czy powodem braku aktywności w LGD (zarówno ich samych, jak i innych członków grupy) jest (czy też nie) brak informacji o tym, że jakieś działanie będzie przez nią realizowane lub że odbędzie się jakieś spotkanie jej członków. Innymi słowy, zwrócono uwagę na to, czy sposoby informowania członków LGD są efektywne.

38 Do projektów zaliczono te, które LGD: a) realizowały ze środków Programu Operacyjnego Kapitał Ludzki, b) wdrażały w ramach projektów współpracy, c) finansowały ze środków innych niż z Programu Rozwoju Obszarów Wiejskich, np. Fundacji Inicjatyw Oświatowych, Akademii Rozwoju Filantropii.

${ }^{39}$ Interesujące było określenie faktycznej aktywności członków tych struktur, które w literaturze przedmiotu opisywane są jako aktywne w największym stopniu (zarządu oraz rady) oraz (na ich tle) zobrazowanie aktywności w tych organizacjach tzw. członków zwyczajnych.

${ }^{40}$ Uwagę skoncentrowano na takich elementach sieci, jak: a) ich liderzy (interesująca była ich liczba oraz postawy badanych w stosunku do motywów ich działalności), b) struktury organizacyjne: zarząd, rada (interesujące było określenie ich aktywności w sieci, składu społecznego oraz wiedzy ich członków na temat zasad rozwoju wielofunkcyjnego i zrównoważonego). Zwrócono również uwagę na kompetencje biur lokalnych grup działania. 
- liczbę funkcjonujących na obszarze partnerstw aktywnych organizacji pozarządowych nowego typu (tj. struktur powstałych po 1989 r., mających osobowość prawną) oraz stowarzyszeń zwykłych w $2010 \mathrm{r}^{41}$;

- dynamikę przyrostu lokalnych grup działania w województwie ${ }^{42}$.

W sferze gospodarczej kapitału społecznego lokalnych grup działania znalazły się ${ }^{43}$ :

- struktura gospodarstw rolnych obszaru partnerstw w $2010 \mathrm{r}^{44}$;

- stopa bezrobocia na obszarze partnerstw w $2010 \mathrm{r}^{45}$;

- liczbę grup producentów rolnych (na obszarze partnerstw) w 2010 r. ${ }^{46}$;

- liczbę firm prowadzonych przez osoby fizyczne poza sektorem rolnym (na

${ }^{41}$ Danych zastanych nie można było pozyskać z lokalnych strategii rozwoju (czyli dokumentów strategicznych LGD). Jeśli zawierały one informacje o liczbie aktywnych KGW oraz innych form tradycyjnej współpracy na obszarze partnerstw (czyli wszystkich gmin zrzeszonych w lokalnych grupach działaniach) oraz o liczbie organizacji pozarządowych nowego typu (w tym stowarzyszeń zwykłych), funkcjonujących na ich obszarze, to najczęściej pochodziły one sprzed 2008 r. (LSR w tej części nie są najczęściej aktualizowane). W związku z tym dane pozyskiwano z Banku Danych Lokalnych, uwzględniającego liczbę stowarzyszeń i innych organizacji społecznych, zarejestrowanych w systemie REGON (w tym liczbę stowarzyszeń zwykłych, które podlegają rejestracji w starostwach powiatowych i są zobowiązane do ewidencji w systemie REGON). Bank ten pozwala również na określenie liczby fundacji na obszarze każdej z gmin należących do badanych partnerstw. Liczbę aktywnych ochotniczych straży pożarnych oszacowano na podstawie informacji od urzędów poszczególnych gmin. Starano się również pozyskać od nich informację na temat liczby aktywnych stowarzyszeń zwykłych. Jednak urzędy gmin nie są zobowiązane do ich ewidencji, w związku z czym odnotowano bardzo wiele braków danych w wypełnianych przez sekretarzy gmin kartach opisu aktywności społecznej na obszarze jednostek samorządu terytorialnego. Stwierdzono, że w przypadku, kiedy odpowiedź była przez nich udzielana, często opierała się na subiektywnych danych pochodzących raczej z ich doświadczeń, niż z jakichkolwiek rejestrów. W związku z powyższym, w analizach skoncentrowano się wyłącznie na danych z Banku Danych Lokalnych.

42 Porównywano liczbę LGD, które zawarły umowę o realizację schematu II PPL+ z FAPA oraz liczbę LGD, które podpisały umowy z urzędami marszałkowskimi o realizację osi 4 Programu Rozwoju Obszarów Wiejskich na lata 2007-2013.

${ }^{43}$ Ustalenie liczby gospodarstw rolnych na obszarze partnerstw prowadzących działalność rolniczą i pozarolniczą oraz gospodarstw rolnych prowadzących wyłącznie działalność pozarolniczą w 2010 r. nie było możliwe. Dane z ostatniego spisu rolnego były niedostępne. W Banku Danych Lokalnych statystyki pochodziły z 2002 r. (były mocno zdezaktualizowane i nie warte uwzględnienia w badaniach). Takimi danymi nie dysponowały również urzędy gmin.

${ }^{44} \mathrm{~W}$ czasie badań okazało się, że nie będzie można oszacować wartości zmiennej, korzystając $\mathrm{z}$ danych z ostatniego spisu rolnego (w momencie badania Główny Urząd Statystyczny nie opracował ich jeszcze dla wszystkich gmin). Nie można było również uwzględnić statystyk Banku Danych Lokalnych, ponieważ były one niekompletne. Wartość zmiennej określono na podstawie informacji pozyskanych od urzędów gmin.

${ }^{45}$ Wartość zmiennej określano na podstawie danych za 2010 r. z Banku Danych Lokalnych.

${ }^{46} \mathrm{~W}$ badaniach zaobserwowano rozbieżność między statystykami Krajowej Sieci Obszarów Wiejskich oraz Agencji Restrukturyzacji i Modernizacji Rolnictwa. W analizach brano pod uwagę drugi z rejestrów (uwzględniający dane za 2012 r.). 
obszarze partnerstwa) w 2010 r. $^{47}$, natomiast uwarunkowania kapitału społecznego lokalnych grup działania związanych ze współpracą sektora społecznego, publicznego i gospodarczego na obszarze ich funkcjonowania to różne wymiary współpracy między sektorem publicznym, społecznym i gospodarczym na obszarze partnerstwa ${ }^{48}$ oraz przywództwo lokalne ${ }^{49} \mathrm{i}$ autorytet władzy lokalnej.

Poza analizą i próbą rozstrzygnięcia opisanych problemów badawczych dotyczących struktury i uwarunkowań kapitału społecznego lokalnych grup działania, w ramach realizowanego projektu głębszej refleksji poddano także kwestię jego znaczenia dla wielofunkcyjnego i zrównoważonego rozwoju wsi ${ }^{50}$. Tym samym realizacja projektu badawczego miała przyczynić się nie tylko do wzbogacenia wiedzy teoretycznej na temat znaczenia i specyfiki polskich lokalnych grup działania w kontekście teorii kapitału społecznego, lecz także zyskać wymiar aplikacyjny. Wnioski z przeprowadzonych badań, pozwalające sformułować odpowiedź na pytanie o to, który z komponentów kapitału społecznego lokalnych grup działania (zaufanie, normy i wartości czy sieć) jest najsłabszy i wymaga wsparcia,

47 Szacując wartość zmiennej, odwołano się do danych z Banku Danych Lokalnych za 2010 r.

${ }^{48}$ Interesujące były trzy wymiary współpracy między sektorem publicznym, gospodarczym oraz społecznym na obszarze partnerstw. Pierwszym z nich był wymiar formalnoprawny współpracy. Tu poszukiwano informacji na temat: a) planów współpracy urzędów gmin z organizacjami pozarządowymi, b) projektów realizowanych przez jednostki samorządu terytorialnego (w latach 2007-2013) na rzecz wsparcia lokalnych przedsiębiorców, c) uproszczeń zastosowanych w urzędach gmin w zakresie obsługi osób fizycznych prowadzących działalność gospodarczą lub osób, które dopiero rejestrują działalność, d) celów zapisanych w lokalnych strategiach rozwoju dotyczących współpracy trzech sektorów. Drugi z wymiarów dotyczył przepływów finansowych w relacjach trzech sektorów. Poszukiwano informacji na temat: wsparcia finansowego udzielanego przez: a) gminy organizacjom pozarządowym, b) przedsiębiorców gminom oraz c) przedsiębiorców organizacjom pozarządowym. Trzeci z wymiarów współpracy trzech sektorów dotyczył interakcji między nimi. Dążono do ustalenia, czy na obszarze gmin zrzeszonych we wszystkich badanych partnerstwach odbywały się spotkania poświęcone: a) współpracy władzy lokalnej z przedsiębiorcami? b) współpracy władzy lokalnej z organizacjami pozarządowymi, c) współpracy przedsiębiorców z organizacjami pozarządowymi.

49 Początkowo, na etapie redagowania wniosku o dofinansowanie projektu i przygotowywania jego koncepcji badawczej zakładano szczegółową identyfikację formalnych i nieformalnych liderów rozwoju wsi oraz jakościową analizę ich roli w inicjowaniu działań na rzecz współpracy międzysektorowej na obszarze partnerstwa. Spowodowana względami finansowymi rezygnacja z części jakościowej badania oraz opisane w dalszej części niniejszego rozdziału problemy z realizacją części ilościowej (zwłaszcza niechęć do ujawniania jakichkolwiek danych personalnych członków LGD) spowodowały, że ten wymiar uwarunkowań ograniczono do zbadania poczucia wpływu respondentów na decyzje władz lokalnych oraz ich przekonań dotyczących tego, czyje interesy i oczekiwania władze te reprezentują.

${ }^{50} \mathrm{~W}$ badaniach przyjęto hipotezę, że niski poziom kapitału społecznego lokalnych grup działania nie sprzyja ich działalności na rzecz wielofunkcyjnego i zrównoważonego rozwoju wsi. Deficyt zaufania społecznego członków tych organizacji, normy i wartości ukierunkowane na realizację interesów partykularnych oraz hierarchizacja sieci (rozumiana, jako przeciwieństwo partnerskich relacji między ich członkami) utrudniają realizację zadań, do których lokalne grupy działania zostały powołane. 
miały stanowić punkt wyjścia do wskazania propozycji sposobów i mechanizmów jego wzmocnienia. W świetle przyjętych założeń, wdrożenie wskazanych mechanizmów powinno przyczynić się do zwiększenia efektywności działania LGD na rzecz wielofunkcyjnego i zrównoważonego rozwoju wsi oraz rozwoju jej społeczeństwa obywatelskiego.

\subsubsection{Zastosowana metoda i wykorzystane techniki badawcze}

Zastosowaną metodą badawczą było studium przypadku, definiowane przez R. Yina: ,[...] jako rodzaj badania empirycznego, w którym bada się współczesne zjawiska w ich społecznym otoczeniu, przy czym granice między tymi badanymi zjawiskami a otoczeniem nie są wyraźnie wyodrębnione i w których wykorzystuje się wiele źródeł danych, wiele technik zbierania i analizy" [1989: 80]. Posługiwano się wielokrotnym studium przypadku, w którym w ramach tego samego procesu badawczego analizuje się kilka przypadków, by je porównać i stworzyć teoretyczne uogólnienie:

Nie jest to badanie zbioru przypadków, lecz instrumentalne studium przypadku rozciągnięte na kilka przypadków. Badacz może, ale nie musi, wiedzieć z góry, że pojedyncze przypadki wchodzące w skład zbioru mają jakąś cechę wspólną. Poszczególne przypadki mogą być do siebie podobne, ale mogą też się różnić. Pewne cechy mogą się powtarzać, inne nie. Wybierając do badań te, a nie inne przypadki, badacz kieruje się przekonaniem, że lepsze zrozumienie tych właśnie przypadków pozwoli mu lepiej zrozumieć, być może i lepiej ująć teoretycznie, zbiór jeszcze liczniejszy. [Stake 1996: 123-124]

Aby zrealizować założone cele w ramach przyjętej metody badawczej, wykorzystano kilka technik badawczych. Pierwszą była ankieta indywidualna, skierowana do członków lokalnych grup działania funkcjonujących na terenie wytypowanych województw (por. rozdział 1.2.3). Dane zebrane za jej pomocą posłużyły do oszacowania poziomu i struktury kapitału społecznego lokalnych grup działania. Pytania zawarte w kwestionariuszu ankiety dotyczyły zagadnień szczegółowych, w większości miały formę pytań zamkniętych (załącznik 1. w aneksie).

Pierwotnie planowano posłużenie się ankietą pocztową i/lub internetową (w sytuacji, gdyby w pojedynczych przypadkach nie udało się ustalić adresu respondenta, a jedynie jego adres mailowy ${ }^{51}$ ), skierowaną do wylosowanej próby członków organizacji, które zamierzano objąć badaniami. W celu pozyskania danych adresowych działaczy skontaktowano się telefonicznie $\mathrm{z}$ biurami wszystkich LGD, a następnie z ich władzami. Kontakt ten został we wszystkich przypadkach

${ }^{51}$ Z wcześniejszych doświadczeń badaczy wynikało, że prezesi grup często zgadzają się tylko na udostępnienie ,służbowych danych” członków LGD, takich jak np. numer telefonu lub adres mailowy. 
poprzedzony pismem, w którym prezentowano ogólne cele projektu badawczego, przedstawiano instytucje uczestniczące $\mathrm{w}$ jego realizacji i finansowaniu, proszono o współpracę polegającą na przekazaniu danych kontaktowych członków grup. Ponieważ odpowiedzi na prośbę pisemną były nieliczne i negatywne, zdecydowano się na formę kontaktu umożliwiającą przekazanie potencjalnym uczestnikom badania większej liczby informacji o nim.

W rozmowach telefonicznych jeszcze raz przypominano najważniejsze cele i założenia projektu badawczego, odpowiadano na ewentualne pytania i starano się wyjaśniać pojawiające się wątpliwości, a także ponownie proszono o umożliwienie kontaktu z członkami organizacji. Niestety, w zdecydowanej większości przypadków władze lokalnych grup konsekwentnie odmówiły udostępnienia nie tylko danych adresowych, lecz także jakichkolwiek danych osobowych członków (zasłaniając się ustawą o ich ochronie), a w kilku przypadkach bardzo niechętnie odniosły się do samego pomysłu ich badania. Tym samym niemożliwe okazało się sporządzenie adekwatnego i kompletnego operatu losowania, stanowiącego podstawę doboru założonej próby ${ }^{52}$.

W związku z tym, do władz wszystkich grup zwrócono się z prośbą o umożliwienie odbycia wizyt w siedzibach organizacji, podczas których możliwe byłoby dokładniejsze przedstawienie idei i planowanego przebiegu badania, a także odbycie spotkań z ich członkami. Uznano, że najlepszą, z punktu widzenia realizacji celów badania, okazją do tego typu spotkań będą walne zgromadzenia członków wybranych LGD. Sądzono, że podczas nich możliwe będzie zrealizowanie przynajmniej części badań ankietowych ${ }^{53}$ (w formie rozdawanej ankiety indywidualnej lub ankiety audytoryjnej), które wprawdzie nie obejmą losowej próby respondentów, ale przynajmniej zapewnią wyższy poziom kontroli kompletności uzyskanych danych niż zakładana wcześniej ankieta pocztowa. Z bezpośrednimi spotkaniami wiązano także nadzieję na dotarcie (pozyskanie danych kontaktowych) do dużej grupy respondentów.

Na podstawie rozmów z przedstawicielami biur oraz władzami wszystkich lokalnych grup działania objętych badaniami sporządzono szczegółowy terminarz walnych zgromadzeń planowanych w okresie wyznaczonym na realizację projektu badawczego. Okazało się, że w części grup, w czasie przeznaczonym na realizację projektu nie zaplanowano żadnego walnego zgromadzenia, zaś $\mathrm{w}$ innych terminy walnych zgromadzeń pokrywały się. Dodatkowo, już w czasie zbierania danych dotyczących terminów spotkań otrzymywano informacje o zmianach (co, niestety, dodatkowo komplikowało sytuację, biorąc pod uwagę fakt, iż realizacja fazy terenowej przypadła na okres zimowy, a siedziby nie-

${ }^{52}$ Dane członków organizacji nie są udostępniane do wiadomości publicznej.

${ }_{53}$ Z rozmów z władzami LGD, dotyczących przeciętnej frekwencji na walnych zgromadzeniach wynikało, że jest ona bardzo zróżnicowana: w niektórych grupach sięga 90-100\%, w innych zdarza się nawet odwołanie zebrania ze względu na absencję członków. 
których grup były zlokalizowane w miejscowościach, do których samo dotarcie, w tym właśnie okresie, zajmowało co najmniej kilkanaście godzin ${ }^{54}$ oraz na fakt, iż zespół badawczy był złożony z 4 osób, wykonujących w czasie realizacji projektu także inne obowiązki związane z pracą zawodową). Jednocześnie, ze strony części organizacji, z którymi kilkakrotnie ustalano termin spotkania i realizacji badania, pojawiła się propozycja rozdysponowania kwestionariuszy ankiet wśród członków za pośrednictwem biura LGD, bez osobistego udziału badaczy.

Opisane powyżej okoliczności oraz wzgląd na porównywalność pozyskiwanych danych spowodowały, że ostatecznie zdecydowano się na zastosowanie wobec wszystkich organizacji tego samego schematu postępowania. Do każdej z nich wysłano lub (jeśli taki był warunek realizacji badania) dostarczono kwestionariusze ankiet w liczbie odpowiadającej liczbie członków organizacji (oszacowanej na podstawie dokumentów i rozmów z władzami) oraz pismo z prośbą o ich dystrybucję wśród działaczy. Wysłanie ankiet poprzedzono uzyskaniem telefonicznej zgody władz na przeprowadzenie badania w tej formie.

Niezależnie od podjęcia opisanych działań, mając na uwadze niewielkie zainteresowanie części potencjalnych respondentów udziałem w badaniu oraz chcąc w jak największym stopniu zrealizować przyjęte założenia, przedstawiciele zespołu badawczego brali udział w wydarzeniach, podczas których możliwe było osobiste spotkanie z reprezentantami lokalnych grup działania i zachęcenie ich do uczestnictwa w realizowanym projekcie. W lutym 2012 r. miały miejsce dwa wydarzenia tego typu: zebranie Małopolskiej Sieci LGD - a więc reprezentantów wszystkich sieci z tego województwa (tutaj, po przeprowadzeniu licznych rozmów, udało się rozdać dodatkowe ankiety i umówić się na monitorowanie zwrotu tych, które już zostały wysłane do poszczególnych grup) oraz konferencja organizowana przez Koronę Północnego Krakowa, skierowana m.in. do osób z małopolskich LGD (tu również udało się rozdysponować dodatkowe ankiety, które później zostały przesłane do zespołu badawczego). Odbyło się także osobiste spotkanie z prezesem jednej z lokalnych grup w jej siedzibie.

W wyniku wszystkich podjętych działań rozdysponowano 1500 kwestionariuszy $^{55}$, z których z powrotem otrzymano 586, a ze względu na zawartość (szczególnie liczne braki danych) do dalszych analiz zakwalifikowano 573 ankiety pochodzące od członków 34 (scharakteryzowanych dokładniej w dalszych rozdziałach) spośród 59 lokalnych grup działania, do których się zwrócono.

${ }^{54} \mathrm{~W}$ niektórych przypadkach układ połączeń kolejowych lub autobusowych uniemożliwiał dotarcie do danej miejscowości w ciągu jednego dnia, co oznaczało, że na uczestnictwo w pojedynczym walnym zgromadzeniu należałoby poświęcić co najmniej trzy dni.

${ }_{55}$ Liczba ta odpowiadała danym na temat łącznej liczby członków poszczególnych LGD, pozyskanym od ich władz z zastrzeżeniem, że nie jest ona stała i część formalnych członków nie działa aktywnie na rzecz grupy. 
W wyniku zastosowanych procedur nie udało się uzyskać próby badawczej, spełniającej warunki próby losowej, a wykorzystana technika zbierania materiałów nie pozwoliła na uzyskanie wyczerpujących danych od wszystkich respondentów ${ }^{56}$, co niewątpliwie ogranicza zakres formułowanych wniosków. Wydaje się jednak, że w celu dotarcia do pierwotnie założonej grupy respondentów (w wyniku napotkanych problemów - do jak największej) podjęto wszystkie działania możliwe do wykonania w okresie przewidzianym na realizację badania, a w ich wyniku uzyskano dane umożliwiające postawienie hipotez dobrze ugruntowanych empirycznie.

Drugą z zastosowanych technik była analiza materiałów zastanych, trzecią - wywiad telefoniczny z pracownikami urzędów gmin, wchodzących w skład analizowanych partnerstw terytorialnych ${ }^{57}$. W przypadku materiałów zastanych skoncentrowano się na charakterystyce treści przekazów ${ }^{58}$.

Wykorzystano kilka narzędzi badawczych:

- kartę opisu aktywności społecznej na obszarze jednostek samorządu terytorialnego, wchodzących w skład lokalnej grupy działania ${ }^{59}$ (załącznik 2. w aneksie);

- kartę opisu aktywności gospodarczej na obszarze jednostek samorządu terytorialnego, wchodzących w skład lokalnej grupy działania ${ }^{60}$ (załącznik 3. w aneksie);

- kartę najważniejszych projektów realizowanych przez lokalne grupy działania $^{61}$ (załącznik 4. w aneksie);

- kartę opisu współpracy sektora publicznego, gospodarczego i społecznego na obszarze jednostek samorządu terytorialnego, wchodzących w skład lokalnej grupy działania ${ }^{62}$ (załącznik 5. w aneksie).

${ }^{56}$ Brak kontroli nad wypełnieniem kwestionariusza we wszystkich technikach opartych na komunikacji pośredniej skutkuje brakami odpowiedzi na niektóre pytania.

${ }^{57}$ Wywiady przeprowadzano w sytuacji braku lub niedostępności adekwatnych źródeł zastanych, w oparciu o szczegółowy kwestionariusz zawierający w większości dychotomiczne pytania-rozstrzygnięcia, dotyczące kwestii ujętych w opracowanych kartach opisu analizowanych wymiarów funkcjonowania LGD (załączniki 1-4 w aneksie).

${ }^{58}$ B. Berelson wśród kryteriów analizy źródeł zastanych wyróżnił: charakterystykę treści przekazów, charakterystykę formy przekazów, charakterystykę nadawcy, charakterystykę odbiorców, charakterystykę efektów przekazu [Berelson 1952, za: Dubiel 1984: 106].

59 Wypełniano ją, posługując się danymi z Banku Danych Lokalnych oraz danymi pozyskanymi z urzędów gmin, wchodzących w skład analizowanych partnerstw terytorialnych.

${ }^{60}$ Wypełniano ją posługując się danymi z Banku Danych Lokalnych oraz danymi pozyskanymi z urzędów gmin wchodzących w skład analizowanych partnerstw terytorialnych.

${ }^{61}$ Wypełniano ją, posługując się informacjami zamieszczonymi na stronach internetowych lokalnych grup działania oraz informacjami pozyskanymi od kierowników biur LGD.

${ }^{62}$ Wypełniano ją, posługując się danymi pozyskanymi z urzędów gmin wchodzących w skład analizowanych partnerstw terytorialnych. 
Za pomocą analizy materiałów zastanych oraz informacji pozyskanych drogą wywiadów telefonicznych określono wartości zmiennych niezależnych, mieszczących się wśród uwarunkowań sfery społecznej i ekonomicznej kapitału społecznego lokalnych grup działania oraz uwarunkowań jego poziomu związanych ze współpracą sektora publicznego, społecznego i gospodarczego na obszarze partnerstw, stworzono również wykaz projektów najważniejszych dla LGD.

\subsubsection{Charakterystyka lokalnych grup działania oraz założenia dotyczące próby badawczej}

Obiektem badania były lokalne grupy działania z województw o najmniejszej i największej liczbie tych organizacji, funkcjonujących na ich obszarze. Przy ich doborze posługiwano się statystykami z okresu realizacji Pilotażowego Programu LEADER+. Zgodnie z przyjętymi założeniami, wszystkie LGD, które wzięto pod uwagę przy konstruowaniu próby badawczej, realizowały schemat II Pilotażowego Programu LEADER $+{ }^{63}$.

Posługując się zaprezentowanym w tabeli 1. wykazem liczby lokalnych grup działania, funkcjonujących na terenie poszczególnych województw [zob. tabela 1], do analizy zakwalifikowano organizacje z województw: lubuskiego, opolskiego oraz zachodniopomorskiego (wchodzące w skład I zbioru - województwa o najmniejszej sieci LGD, funkcjonującej na ich obszarze), a także małopolskiego, podkarpackiego i wielkopolskiego (należące do II zbioru - województwa charakteryzujące się największym „nasyceniem” organizacjami tego typu) ${ }^{64}$. O udział w badaniu zwrócono się do wszystkich grup działających na terenie wytypowanych województw (59 LGD). Zgodę na udział w badaniu wyrazili przedstawiciele nieco ponad połowy spośród nich (34 LGD), w tym 9 z 14 lokalnych grup działania wchodzących w skład pierwszego zbioru oraz 25 z 45 lokalnych grup działania wchodzących w skład drugiego zbioru.

${ }^{63}$ W Polsce funkcjonują również lokalne grupy działania, które powstały po zakończeniu realizacji Pilotażowego Programu LEADER+. Rozpoczęły one praktyczne funkcjonowanie najczęściej dopiero w latach 2009-2010 [zob. Zajda 2010]. W opinii badaczy jest to zbyt krótki okres, by wnioskować na temat potencjału ich kapitału społecznego i jego wpływu na wielofunkcyjny i zrównoważony rozwój wsi.

${ }^{64}$ We wniosku założono pierwotnie, że każdy typ województw, tj. województwa o najmniejszej liczbie tych organizacji oraz województwa o największej ich liczbie, będzie reprezentowany przez dwa z nich. Jednak analiza wielkości sieci (składu LGD) oraz wstępne rozpoznanie terenu badań (skłonności potencjalnych respondentów do uczestnictwa w projekcie) wykazały, iż włączenie po jednym dodatkowym województwie do każdego ze zbiorów zwiększy szansę uzyskania założonej liczby zwrotów kwestionariuszy ankiet (dając podstawę do sformułowania wniosków o szerszym zakresie). 
W województwie lubuskim badaniem zostały objęte trzy partnerstwa terytorialne: Stowarzyszenie Lokalna Grupa Działania Regionu Kozła ${ }^{65}$, Fundacja Porozumienie Wzgórz Dałkowskich ${ }^{66}$, Fundacja Zielonej Doliny Odry i Warty ${ }^{67}$.

Partnerstwa zrzeszają mieszkańców od 6 do 12 gmin usytuowanych na obszarze od 3 do 5 powiatów. Dwa z nich tworzą gminy administracyjnie przynależące do dwóch województw (lubuskiego i wielkopolskiego oraz lubuskiego i dolnośląskiego) [zob. tabela 2].

Tabela 1. Wykaz podpisanych umów w schemacie II ${ }^{68}$

\begin{tabular}{|l|c|}
\hline \multicolumn{1}{|c|}{ Województwo } & $\begin{array}{c}\text { Liczba podpisanych umów } \\
\text { w schemacie II }\end{array}$ \\
\hline \multicolumn{1}{|c|}{1} & 2 \\
\hline dolnośląskie & 11 \\
\hline kujawsko-pomorskie & 13 \\
\hline lubelskie & 8 \\
\hline lubuskie & 4 \\
\hline łódzkie & 9 \\
\hline małopolskie & 16 \\
\hline mazowieckie & 9 \\
\hline
\end{tabular}

${ }^{65}$ Geneza Stowarzyszenia Lokalna Grupa Działania Regionu Kozła sięga 1995 r. Z inicjatywy 7 gmin powstało wtedy Stowarzyszenie Gmin RP Regionu Kozła. W 2006 r. (tj. w czasie realizacji schematu I PPL+) jego członkowie podjęli decyzję o zarejestrowaniu LGD. Uzyskała ona dofinansowanie na realizację schematu II PPL+. Nazwa grupy pochodzi od instrumentu, którym do dziś posługują się koźlarze. W LSR podkreślono, że o spójności obszaru partnerstwa decydują przede wszystkim uwarunkowania kulturowe. Należy do nich instrument i historia związana z germanizacją i walką o polskość [LSR: 24, 32].

${ }^{66}$ Fundacja Porozumienie Wzgórz Dałkowskich została utworzona w 2006 r. Jej geneza wiąże się z działaniami gminy Grębocice i Fundacji Ekologicznej Zielona Akcja z Legnicy (mającymi na celu powołanie Grupy Partnerskiej Porozumienie Wzgórz Dałkowskich) [LSR: 11]. Nazwa fundacji nawiązuje do geograficznego usytuowania obszaru, który obejmuje wsparciem. O jego spójności decydują przede wszystkim elementy związane z rozległymi dolinami wielkich rzek i krajobrazem nadrzecznym [LSR: 21].

${ }^{67}$ Nazwa Fundacji Zielonej Doliny Odry i Warty również nawiązuje do cech przyrodniczych obszaru, który obejmuje wsparciem. Jej geneza jest związana z inicjatywą jednej z gmin (Górzycy), która w 2004 r. zainicjowała warsztaty poświęcone budowie partnerstwa. Fundacja została zarejestrowana w KRS w 2006 r.

${ }^{68}$ Wykaz podpisanych umów w schemacie II jest równoznaczny z liczbą LGD realizujących w danym województwie schemat II, lecz nie z liczbą grup funkcjonujących ogółem w województwach. W czasie realizacji schematu II powstawały grupy przygotowujące się do aplikowania o środki PROW. Istniały również grupy, które środków na realizację schematu II nie otrzymały. 
Tabela 1. (cd.)

\begin{tabular}{|l|c|}
\hline \multicolumn{1}{|c|}{1} & 2 \\
\hline opolskie & 4 \\
\hline podkarpackie & 15 \\
\hline podlaskie & 8 \\
\hline pomorskie & 7 \\
\hline śląskie & 9 \\
\hline świętokrzyskie & 9 \\
\hline warmińsko-mazurskie & 8 \\
\hline wielkopolskie & 14 \\
\hline zachodniopomorskie & 6 \\
\hline
\end{tabular}

Źródło: [Borek, Fałkowski i in. 2006: 39, 53] oraz [Borek 2007: 11]

Tabela 2. Cechy LGD z województwa lubuskiego

\begin{tabular}{|c|c|c|c|}
\hline Nazwa LGD & $\begin{array}{c}\text { Liczba gmin } \\
\text { tworzących LGD }\end{array}$ & $\begin{array}{c}\text { Nazwa } \\
\text { województwa }\end{array}$ & Nazwa powiatu \\
\hline \multirow{5}{*}{$\begin{array}{l}\text { Stowarzyszenie Lokalna } \\
\text { Grupa Działania Regionu } \\
\text { Kozła }\end{array}$} & \multirow{5}{*}{6} & \multirow{3}{*}{ lubuskie } & zielonogórski \\
\hline & & & międzyrzecki \\
\hline & & & świebodziński \\
\hline & & \multirow{2}{*}{ wielkopolskie } & wolsztyński \\
\hline & & & nowotomyski \\
\hline \multirow{4}{*}{$\begin{array}{l}\text { Fundacja Porozumienie } \\
\text { Wzgórz } \\
\text { Dałkowskich }\end{array}$} & \multirow{4}{*}{12} & \multirow{2}{*}{ lubuskie } & żagański \\
\hline & & & nowosolski \\
\hline & & \multirow{2}{*}{ dolnośląskie } & polkowicki \\
\hline & & & głogowski \\
\hline \multirow{3}{*}{$\begin{array}{l}\text { Fundacja Zielonej Doliny } \\
\text { Odry i Warty }\end{array}$} & \multirow{3}{*}{6} & \multirow{3}{*}{ lubuskie } & sulęciński \\
\hline & & & słubicki \\
\hline & & & gorzowski \\
\hline
\end{tabular}

Źródło: opracowanie własne. 
Tabela 3. Cechy LGD z województwa opolskiego

\begin{tabular}{|l|c|l|}
\hline \multicolumn{1}{|c|}{ Nazwa LGD } & $\begin{array}{c}\text { Liczba gmin } \\
\text { tworzących LGD }\end{array}$ & \multicolumn{1}{|c|}{ Nazwa powiatu } \\
\hline \multirow{2}{*}{$\begin{array}{l}\text { Partnerstwo Borów Niemo- } \\
\text { dlińskich }\end{array}$} & 7 & opolski \\
\cline { 2 - 3 } & \multirow{2}{*}{ krapkowicki } \\
\cline { 2 - 3 } Dolina Stobrawy & 3 & nyski \\
\hline \multirow{2}{*}{ EURO Country } & 7 & kluczbordzierzyńsko-kozielski \\
\cline { 2 - 3 } & & prudnicki \\
\hline
\end{tabular}

Źródło: opracowanie własne.

W Opolskiem badaniem objęto trzy lokalne grupy działania ${ }^{69}$ : Partnerstwo Borów Niemodlińskich ${ }^{70}$, Dolinę Stobrawy ${ }^{71}$ oraz EURO Country ${ }^{72}$. Wspierają one od 3 do 7 gmin usytuowanych na obszarze jednego województwa [tabela 3 ].

${ }^{69}$ Do LGD realizujących schemat II PPL+ w Opolskiem należy również LGD Wspólne Źródła. Od jej przedstawicieli nie otrzymano jednak wypełnionych kwestionariuszy ankiety, w związku z czym organizacja nie została włączona do badań.

${ }^{70}$ Geneza powstania Partnerstwa Borów Niemodlińskich sięga 2003 r., kiedy Rada Gminy Prószków podjęła uchwałę w sprawie utworzenia stowarzyszenia jednostek samorządu terytorialnego „Zielone Gminy”. W jego skład weszły gminy: Niemodlin, Komprachcice, Łambinowice, Tułowice oraz powiat opolski. Gmina Prószków (wraz z pozostałymi) złożyła wniosek o możliwość realizacji schematu I PPL+. W 2006 r. partnerstwo zostało zarejestrowane jako stowarzyszenie. Jego nazwa nawiązuje do największego na lewym brzegu górnej Odry kompleksu leśnego z licznymi stawami i torfowiskami [LSR: 6-7].

${ }^{71}$ Formę prawną stowarzyszenia przybrało również partnerstwo Dolina Stobrawy (zarejestrowane w 2006 r.). O jego genezie czytamy: „W procesie budowania partnerstwa wykorzystano doświadczenie w tworzeniu Sektorowej Strategii Rozwoju Turystyki na obszarach wiejskich w gminach: Kluczbork, Wołczyn i Lasowice Wielkie w ramach Pilotażowego Programu Leader+. Ówczesne działania zaowocowały powołaniem Stowarzyszenia Rozwoju Ziemi Kluczborskiej LEADER. W skład stowarzyszenia oprócz wcześniej wymienionych gmin wchodziła także gmina Byczyna, która w późniejszym czasie wycofała się z uczestnictwa budowanego partnerstwa [...] Odbyły się ogółem 3 spotkania z mieszkańcami, których efektem było utworzenie Stowarzyszenia Lokalna Grupa Działania DOLINA STOBRAWY i opracowanie Lokalnej Strategii Rozwoju Obszaru Dolina Stobrawy oraz otrzymanie dofinansowania na realizację zadań określonych w Strategii” [LSR: 4]. Nazwa partnerstwa nawiązuje do rzeki Stobrawy, która przepływa przez gminy wchodzące w jego skład.

72 Partnerstwo przybrało formę prawną fundacji. Jej geneza związana jest $\mathrm{z}$ inicjatywą sektora publicznego - gmin Cisek i Polskiej Cerekwi, które brały udział w realizacji Pilotażowego Programu LEADER+ [LSR: 5]. W LSR nie odnajdujemy informacji na temat fundatora lokalnej grupy działania. Z informacji zamieszczonych na jej stronie internetowej wynika, że była nią firma SOLIDARIS, co sam proces powoływania do życia struktury czyni bardzo ciekawym (najczęściej fundatorami LGD były samorządy gmin). Nazwa organizacji nawiązuje do społeczno-kulturowego zróżnicowania obszaru, zamieszkiwanego przez Polaków, Niemców oraz osób deklarujących tożsamość Śląską. 
W Zachodniopomorskiem badaniem objęto trzy lokalne grupy działania ${ }^{73}$. Wspierają one mieszkańców od 6 do 12 gmin. Są to: Szanse Bezdroży Gmin Powiatu Goleniowskiego ${ }^{74}$, Stowarzyszenie Lider Pojezierza ${ }^{75}$ oraz Fundacja Środkowopomorska Grupa Działania ${ }^{76}$ [tabela 4].

Drugi zbiór obejmował lokalne grupy działania usytuowane w województwach, w których schemat II PPL+ wdrażało najwięcej struktur tego typu. Z Wielkopolski obiektem badania ${ }^{77}$ były: Lokalna Grupa Działania Gościnna Wielkopolska $^{78}$, Ostrzeszowska Lokalna Grupa Działania ${ }^{79}$, Lokalna Grupa Działania Stowarzyszenie KOLD ${ }^{80}$, Stowarzyszenie Światowid ${ }^{81}$ oraz Stowarzyszenie Czarnkowsko-Trzcianecka Lokalna Grupa Działania ${ }^{82}$ [tabela 5].

${ }^{73} \mathrm{~W}$ próbie pierwotnie uwzględniono również LGD WIR - Wiejska Inicjatywa Rozwoju. Nie otrzymano zwrotu kwestionariuszy ankiet, w związku z czym wykluczono ją z badań.

${ }^{74}$ LGD przybrała formą prawną stowarzyszenia (zarejestrowanego w KRS w 2006 r.). Jego powstanie zostało zainicjowane przez reprezentantów sektora publicznego. Wszystkie gminy objęte jego wsparciem wchodzą w skład jednego powiatu, do czego nawiązuje jego nazwa.

${ }^{75}$ Inicjatorem powstania stowarzyszenia Lider Pojezierza byli również reprezentanci sektora publicznego (gminy Barlinek). Nazwa tej lokalnej grupy działania również nawiązuje do geograficznego usytuowania gmin, które obejmuje wsparciem. W trakcie realizacji schematu II PPL+ do stowarzyszenia przystąpiły gminy Bierzwnik, Trzcińsko Zdrój oraz Choszczno [LSR: 5].

${ }^{76} \mathrm{~W}$ skład fundacji wchodzą przedstawiciele 11 gmin z 4 powiatów. Do grona jej fundatorów należała Politechnika Koszalińska oraz Stowarzyszenie Gmin i Powiatów Pomorza Środowego (powstałe w wyniku przekształcenia Związku Miast i Gmin Pomorza Środkowego). Inicjatorem powołania partnerstwa była również Fundacja Nauka dla Środowiska. W 2008 r. nastąpiło rozszerzenie składu LGD o gminę Mielno oraz powiat koszaliński [LSR: 5-6].

77 W Wielkopolsce w okresie 2004-2006 powstało 14 LGD. Oprócz wymienionych 5 materiał badawczy pozyskano także od LGD „Między Ludźmi i Jeziorami”. Były to jednak tylko dwa kwestionariusze ankiety, w związku z czym tej LGD nie włączono do próby. Nie uzyskano kwestionariuszy od LGD: „Wspólnie dla Przyszłości”, „Doliny Noteci” oraz „LGD 7 - Kraina Nocy i Dni”. Pozostałe 5 LGD („Dolina Wełny”, „Kraina Lasów i Jezior”, „Stowarzyszenie Ziemi Grodzkiej”, „Unia Nadwarciańska” i „Puszcza Notecka”) nie realizowały schematu II PPL+.

${ }^{78}$ Początki partnerstwa sięgają 2002 r., kiedy dziewięć gmin: Gostyń, Jutrosin, Kościan, Krobia, Krzywiń, Miejska Górka, Pakosław, Pępowo i Piaski powołało Międzygminny Związek Turystyczny „Wielkopolska Gościnna” w celu tworzenia warunków rozwoju turystyki w gminach oraz wypracowania ponadgminnej, ujednoliconej oferty turystycznej. Związek wdrażał schemat I PPL+ (przystąpiły do niego również gmina Dolsk oraz Kobylin) [LSR: 4-6].

79 Jej nazwa nawiązuje do usytuowania gmin, które obejmuje wsparciem (wszystkie administracyjnie przynależą do jednego powiatu). W LSR nie odnajdujemy informacji na temat podmiotu, który zainicjował jej powstanie. Czytamy jedynie, że: „Początkowo członkami SOLGD były tylko osoby fizyczne, jednakże w związku z wyzwaniami jakie wiązały się z realizacją projektu w ramach Pilotażowego Programu Leader+ grono członków rozszerzyło się o jednostki samorządu terytorialnego, instytucje kultury, przedsiębiorstwa i organizacje społeczne" [LSR: 4].

${ }^{80}$ Geneza LGD KOLD sięga 2004 r. Jej inicjatorami byli przedstawiciele samorządów gmin Kuślin, Opalenica, Lwówek i Duszniki (nazwa organizacji pochodzi od pierwszych liter nazw poszczególnych gmin). W 2007 i 2008 r. poszerzono jej skład o przedstawicieli gmin Nowy Tomyśl, Pniewy i Miedzichowo [LSR: 5].

${ }^{81}$ Stowarzyszenie zostało zarejestrowane w 2004 r. z inicjatywy przedsiębiorców i rolników z gminy Łubowo koło Gniezna. Realizowało ono schemat I PPL+ [LSR: 3-4].

${ }^{82}$ Stowarzyszenie powstało z inicjatywy sektora publicznego. Jego geneza sięga $2005 \mathrm{r}$. 
Tabela 4. Cechy LGD z województwa zachodniopomorskiego

\begin{tabular}{|c|c|c|}
\hline Nazwa LGD & $\begin{array}{c}\text { Liczba gmin } \\
\text { tworzących LGD }\end{array}$ & Nazwa powiatu \\
\hline $\begin{array}{l}\text { Szanse Bezdroży Gmin } \\
\text { Powiatu Goleniowskiego }\end{array}$ & 6 & goleniowski \\
\hline \multirow{4}{*}{$\begin{array}{l}\text { Stowarzyszenie Lider } \\
\text { Pojezierza }\end{array}$} & \multirow{4}{*}{12} & myśliborski \\
\hline & & choszczeński \\
\hline & & pyrzycki \\
\hline & & gryfiński \\
\hline \multirow{4}{*}{$\begin{array}{l}\text { Fundacja Środkowopomorska } \\
\text { Grupa Działania }\end{array}$} & \multirow{4}{*}{11} & koszaliński \\
\hline & & białogardzki \\
\hline & & szczecinecki \\
\hline & & sławieński \\
\hline
\end{tabular}

Źródło: opracowanie własne.

Tabela 5. Cechy LGD z województwa wielkopolskiego

\begin{tabular}{|c|c|c|}
\hline Nazwa LGD & $\begin{array}{l}\text { Liczba gmin } \\
\text { tworzących LGD }\end{array}$ & Nazwa powiatu \\
\hline 1 & 2 & 3 \\
\hline \multirow{5}{*}{$\begin{array}{l}\text { LGD Gościnna } \\
\text { Wielkopolska }\end{array}$} & \multirow{5}{*}{10} & śremski \\
\hline & & rawicki \\
\hline & & krotoszyński \\
\hline & & kościański \\
\hline & & gostyński \\
\hline Stowarzyszenie Ostrzeszowska LGD & 7 & ostrzeszowski \\
\hline \multirow{2}{*}{ KOLD } & \multirow{2}{*}{7} & szamotulski \\
\hline & & nowotomyski \\
\hline \multirow{3}{*}{ Stowarzyszenie Światowid } & \multirow{3}{*}{14} & gnieźnieński \\
\hline & & poznański \\
\hline & & wrzesiński \\
\hline $\begin{array}{l}\text { Stowarzyszenie Czarnkowsko-Trzcianecka } \\
\text { Lokalna Grupa Działania }\end{array}$ & 7 & czarnkowsko-trzcianecki \\
\hline
\end{tabular}

Źródło: opracowanie własne. 
Z Małopolski do operatu włączono 11 lokalnych grup działania: Dunajec-Bia$\mathrm{la}^{83}$, OPARA ${ }^{84}$, Dolina Karpia ${ }^{85}$, Jaksa ${ }^{86}$, Stowarzyszenie Rozwoju Spisza i Okolicy ${ }^{87}$,

Tabela 6. Cechy LGD z województwa małopolskiego

\begin{tabular}{|l|c|l|}
\hline \multicolumn{1}{|c|}{ Nazwa LGD } & $\begin{array}{c}\text { Liczba gmin } \\
\text { tworzących LGD }\end{array}$ & \multicolumn{1}{|c|}{ Nazwa powiatu } \\
\hline 1 & 2 & 3 \\
\hline LGD Dunajec - Biała & 4 & tarnowski \\
\hline $\begin{array}{l}\text { Stowarzyszenia na Rzecz Rozwoju Płasko- } \\
\text { wyżu Proszowickiego „ProKoPaRa” }\end{array}$ & 4 & proszowicki \\
\hline
\end{tabular}

${ }^{83} \mathrm{~W}$ proces powstawania LGD Dunajec-Biała zaangażowana była Fundacja Instytut Karpacki. Z jej inicjatywy w 2005 r. rozpoczęto organizację spotkań informacyjnych na temat podejścia LEADER. W LSR czytamy: „Do udziału w LGD Dunajec-Biała zostały zaproszone wszystkie samorządy gminne oraz wszyscy liczący się partnerzy społeczno-gospodarczy z terenu 4 gmin oraz najważniejsze stowarzyszenia działające w sąsiedztwie przyszłej LGD, mające siedzibę poza jej obszarem" [LSR: 6]. Nazwa organizacji nawiązuje do jej usytuowania geograficznego - większość obszaru, który obejmuje wsparciem znajduje się na Pogórzu Ronowskim, między Dunajcem i Białą [ LSR: 20-21].

${ }^{84}$ Inicjatorem powstania Stowarzyszenia na Rzecz Rozwoju Płaskowyżu Proszowickiego „ProKoPaRa” była jedna z gmin (Koniusza). Powstało ono w 2006 r. [LSR: 3]. Nazwa organizacji również nawiązuje do geograficznego usytuowania gmin.

${ }^{85}$ Dolina Karpia stanowi wyjątek spośród lokalnych grup działania, wylosowanych do badań w Małopolsce. Jako stowarzyszenie została zarejestrowana w 2006 r. Inicjatorem jej powstania byli reprezentanci samorządów terytorialnych [LSR: 5]. Nie uzyskała jednak dofinansowania na realizację schematu II PPL+ (stowarzyszenie złożyło wniosek, który nie uzyskał pozytywnej oceny formalnej). W tym okresie LGD kontynuowała swoją działalność, głównie w zakresie promocji turystycznego potencjału obszaru oraz jego podstawowego produktu - karpia zatorskiego. W LSR czytamy, że: „Przedstawiciele Stowarzyszenia Doliny Karpia brali udział w wielu spotkaniach mających na celu promocję i popularyzację obszaru Doliny Karpia i jego produktów lokalnych. Organizacja uczestniczyła w Targach Przedsiębiorczości, organizowanych w 2006 r. w Chrzanowie [...]. Stowarzyszenie brało również udział wspólnie z Urzędem Miasta Zator i Instytutem Rybactwa Śródlądowego w Zatorze w konkursie na najlepszy produkt lokalny z terenu Małopolski” [LSR: 10]. Nazwa partnerstwa nawiązuje do jego najbardziej charakterystycznego produktu lokalnego karpia: „Rybactwo na terenie Doliny jest nie tylko ważną dziedziną lokalnej gospodarki, ale także rodzajem dziedzictwa kulturowego, szczególnie ze względu na swą długą i bogatą historię. Tradycja hodowli ryb sięga tu 1291 r., kiedy to w Bachowicach odnowiono zamulone wylewem Wisły jezioro i rozpoczęto w nim gospodarkę rybacką" [LSR: 40]. Kontynuowanie działań przez LGD uzasadniło włączenie jej do badań.

${ }^{86}$ Stowarzyszenie powstało w 2006 r. Obejmuje wsparciem mieszkańców 7 gmin usytuowanych na obszarze jednego powiatu. Jego nazwa nawiązuje do legendarnej postaci rycerza Jaksy z rodu Gryfitów (wsławionego ufundowaniem trzech klasztorów) [LSR: 46].

${ }^{87}$ Stowarzyszenie powstało w 2005 r. z inicjatywy przedstawicieli sektora publicznego władz lokalnych 3 gmin. Jego nazwa nawiązuje do regionu historycznego, usytuowanego w Karpatach Centralnych i Zachodnich. 


\begin{tabular}{|c|c|c|}
\hline 1 & 2 & 3 \\
\hline \multirow{2}{*}{ Dolina Karpia } & \multirow{2}{*}{7} & oświęcimski \\
\hline & & wadowicki \\
\hline Miechowskie Stowarzyszenie Gmin Jaksa & 7 & miechowski \\
\hline \multirow{2}{*}{ Stowarzyszenie Rozwoju Spisza i Okolicy } & \multirow{2}{*}{3} & tatrzański \\
\hline & & nowotarski \\
\hline Stowarzyszenie Rozwoju Orawy & 2 & nowotarski \\
\hline Gorce-Pieniny & 3 & nowotarski \\
\hline \multirow{2}{*}{ Gościniec 4 Żywiołów } & \multirow{2}{*}{4} & tarnowski \\
\hline & & wadowicki \\
\hline Korona Północnego Krakowa & 7 & krakowski \\
\hline LGD Olkusz & 1 & olkuski \\
\hline \multirow{2}{*}{ Podhalańska LGD } & \multirow{2}{*}{5} & tatrzański \\
\hline & & nowotarski \\
\hline
\end{tabular}

Źródło: opracowanie własne.

Stowarzyszenie Rozwoju Orawy ${ }^{88}$, Gorce-Pieniny ${ }^{89}$, Gościniec 4 Żywiołów ${ }^{90}$, Korona Północnego Krakowa ${ }^{91}$, LGD Olkusz ${ }^{92}$, Podhalańska LGD ${ }^{93}$ [tabela 6].

${ }^{88}$ Nazwa stowarzyszenia (zarejestrowanego w 2005 r.) nawiązuje do krainy historyczno-etnograficznej, usytuowanej na obszarze Polski oraz Słowacji.

${ }^{89}$ Stowarzyszenie powstało z inicjatyw władz gminy Kościeńsko nad Dunajcem oraz Ochotnicy Dolnej, które we współpracy ze Stowarzyszeniem Uniwersytetów Ludowych w Krakowie złożyły wniosek do schematu I PPL+. Jego nazwa nawiązuje do pasma górskiego Gorce-Pieniny.

${ }_{90}$ Stowarzyszenie powstało w 2006 r. Skupiało reprezentantów 4 gmin. Każdej z nich symbolicznie przypisano reprezentowanie jednego z 4 potencjałów przyrodniczo-kulturowych (tzw. $̇ y-$ wiołów), o których mowa w nazwie stowarzyszenia: ziemi, wody, powietrza i ognia. Ze współpracy wycofała się gmina Sułkowice (ogień). Akces do LGD zgłosiła natomiast Kalwaria Zebrzydowska (drewno)[http://gosciniec4zywiolow.pl/index.php?id_kategoria=147].

${ }^{91}$ Stowarzyszenie powstało w 2006 r. z inicjatywy władz lokalnych 7 gmin. Nazwa nawiązuje do ich przestrzennego usytuowania: Podczas zebrania prezentowano wirtualna mape obszaru Korony. Skojarzyła się ona uczestnikom zebrania z Korona. Dodatkowym argumentem podczas dyskusji w czasie zebrania było: faktyczne ulokowanie obszaru tych gmin po stronie Pótnocnego Krakowa, oraz nadań Królewskich, które datuja się już od XIII wieku dla wsi na tym obszarze [http://www. koronakrakowa.pl/cms/index.php?option=com_content\&task=view\&id=214\&Itemid=161].

92 Stowarzyszenie Lokalna Grupa Działania dla Obszarów Wiejskich Gminy Olkusz powstało w 2006 r. Działa na rzecz jednej gminy.

93 Stowarzyszenie powstało w 2006 r. Jego nazwa nawiązuje do usytuowania geograficznego gmin wchodzących w skład partnerstwa (region Podhala). 
Z Podkarpacia obiektem badania były LGD: Subregion Magurski ${ }^{94}$, Partnerstwo dla Ziemi Niżańskiej ${ }^{95}$, Lasovia ${ }^{96}$, CK Podkarpacie ${ }^{97}$, PROWENT $^{98}$, Kraina $\mathrm{Sanu}^{99}$, Dolina Strugu ${ }^{100}$, Dorzecze Wisłoka ${ }^{101}$, Czarnorzecko-Strzyżowska LGD ${ }^{102}$ [tabela 7].

${ }^{94}$ Stowarzyszenie Subregion Magurski - szansa na rozwój powstało w 2006 r. na skutek inicjatywy władz lokalnych czterech gmin. Wdrażało schemat II PPL+. Po jego zakończeniu obszar, który obejmuje wsparciem zmniejszył się do dwóch gmin. W LSR nie odnajdujemy informacji na temat przyczyn rezygnacji reprezentantów dwóch gmin z udziału w partnerstwie. Nazwa lokalnej grupy działania nawiązuje do Magurskiego Parku Narodowego, na obszarze którego ulokowane są części obu gmin [LSR: 14].

95 Geneza Partnerstwa dla Ziemi Niżańskiej sięga 2003 r. i wiąże się z realizacją polsko-holenderskiego projektu „Wsparcie Budowania Instytucji na rzecz Rozwoju Obszarów Wiejskich”, w którym uczestniczyły powiaty: leżajski, biłgorajski oraz niżański. W LSR czytamy: „W wyniku tych szkoleń powstał zalążek Lokalnej Grupy Działania łączącej osoby z trzech sektorów: samorządowców, przedsiębiorców oraz organizacji pozarządowych. To właśnie oni stanowili trzon organizacyjny, który wspólnie ze Starostwem Powiatowym w Nisku, Urzędem Gminy i Miasta Ulanów oraz Stowarzyszeniem „Niżańskie Centrum Rozwoju” opracował [...] dla wszystkich gmin powiatu niżańskiego projekt pod nazwą „Aktywność mieszkańców szansą rozwoju powiatu niżańskiego” [LSR: 4]. Uzyskał on akceptację FAPA, ale został oceniony negatywnie przez Regionalną Izbę Obrachunkową w Rzeszowie. Pomimo braku środków ze schematu I PPL+ w 2006 r. zarejestrowano stowarzyszenie, zrealizowano założenia projektu oraz złożono (oceniony pozytywnie) wniosek do schematu II PPL+ [LSR: 5].

96 LGD Lasovia została zarejestrowana jako stowarzyszenie w 2005 r. (w wyniku realizacji schematu I PPL+). Jej geneza wiąże się z inicjatywą sektora publicznego - przedstawicieli trzech samorządów gmin. Organizacja realizowała schemat II. Jej nazwa nawiązuje do dziedzictwa społeczno-kulturowego. Gminy są usytuowane na obszarze, który był zamieszkiwany przez lud nazywany Lasowiakami: „Lokalna Grupa Działania przyjęła nazwę LASOVIA dla podkreślenia więzi z tradycją tej ziemi" [LSR: 35].

${ }^{97}$ Inicjatorem jej powstania była jedna z gmin (Czudec), która aplikowała o środki ze schematu I PPL+. Nazwa organizacji stanowi akronim od określenia Centrum Kultury Podkarpacie. Stowarzyszenie zarejestrowano w 2005 r. Wdrażało ono schemat II PPL+.

${ }^{98}$ Nazwa LGD pochodzi od akronimu: Partnerstwo dla Rozwoju Obszarów Wiejskich Ekonomika - Nauka - Tradycja. Powstała ona w 2006 r. z inicjatywy Fundacji Międzynarodowe Centrum Kształcenia i Rozwoju Gospodarczego [http://www.prowent.migron.org.pl/o_nas/].

99 Stowarzyszenie powstało w $2006 \mathrm{r}$. Wszystkie gminy zrzeszone w nim są ulokowane na obszarze Kotliny Sandomierskiej (której środkowa część pokrywa się z Doliną Dolnego Sanu) [LSR: 23-25].

100 Jedno z najsłynniejszych polskich partnerstw terytorialnych, którego geneza sięga lat 90 . Określenie „Dolina Strugu” nie jest terminem geograficznym czy administracyjnym. Spopularyzowali je na początku lat 90. samorządowcy tego terenu, określając tak obszar wspólnych wówczas przedsięwzięć [http://www.dolinastrugu.pl/?q=node/6].

${ }^{101}$ Geneza stowarzyszenia sięga 2005 r. Z inicjatywy Fundacji Wiedza i Rozwój (działającej przy PWSZ w Nowym Sączu) realizowano schemat I PPL+ na obszarze 4 gmin: Rymanów, Besko, Zarszyn, Tyrawa Wołoska. W 2006 r. powołano LGD, która przyjęła formę prawną fundacji o nazwie „Pomóżmy sobie sami” (realizowała schemat II PPL+). W 2008 r. formę prawną fundacji zastąpiono stowarzyszeniem. Jego członkami nie są mieszkańcy gminy Tyrawa Wołoska, ale akces do niego zgłosiła gmina Bukowsko [LSR: 4-5].

${ }^{102}$ W 2006 r. z inicjatywy gminy Strzyżów powołano Wiejską Lokalną Grupę Działania w Strzyżowie, która realizowała schemat II PPL+. W 2007 r. akces do niej zgłosiło 5 gmin, w związku 
Tabela 7. Cechy LGD z województwa podkarpackiego

\begin{tabular}{|c|c|c|}
\hline Nazwa LGD & $\begin{array}{c}\text { Liczba gmin tworzących } \\
\text { LGD }\end{array}$ & Nazwa powiatu \\
\hline 1 & 2 & 3 \\
\hline Subregion Magurski & 2 & jasielski \\
\hline Partnerstwo dla Ziemi Niżańskiej & 7 & niżański \\
\hline \multirow{2}{*}{ Lasovia } & \multirow{2}{*}{3} & kolbuszowski \\
\hline & & ropczycko-sędziszowski \\
\hline \multirow{2}{*}{ CK Podkarpacie } & \multirow{2}{*}{3} & strzyżowski \\
\hline & & ropczycko-sędziszowski \\
\hline 1 & 2 & 3 \\
\hline PROWENT & 10 & mielecki \\
\hline \multirow{3}{*}{ Kraina Sanu } & \multirow{3}{*}{7} & leżajski \\
\hline & & przeworski \\
\hline & & jarosławski \\
\hline Dolina Strugu & 4 & rzeszowski \\
\hline \multirow{2}{*}{ Dorzecze Wisłoka } & \multirow{2}{*}{4} & krośnieński \\
\hline & & sanocki \\
\hline \multirow{2}{*}{ Czarnorzecko-Strzyżowska LGD } & \multirow{2}{*}{6} & strzyżowski \\
\hline & & krościeński \\
\hline
\end{tabular}

Źródło: opracowanie własne.

W zbiorze pierwszym znalazły się zatem: 1) trzy lokalne grupy działania z województwa lubuskiego (zrzeszające mieszkańców 24 gmin), 2) trzy lokalne grupy działania z województwa opolskiego (zrzeszające mieszkańców 17 gmin), 3) trzy lokalne grupy działania $z$ województwa zachodniopomorskiego (zrzeszające mieszkańców 29 gmin). W drugim zbiorze również znalazły się lokalne grupy działania z trzech województw: 1) wielkopolskiego -5 organizacji, które zrzeszały mieszkańców 35 gmin, 2) małopolskiego - 11 organizacji, które zrzeszały mieszkańców 47 gmin, 3) podkarpackiego - 9 organizacji, które zrzeszały mieszkańców 46 gmin. Od członków (partnerów) LGD z pierwszego zbioru pozyskano 103 kwestionariusze ankiety, od członków LGD z drugiego - 470.

W związku z tym, że celem projektu badawczego było nie tylko oszacowanie poziomu i opisanie struktury kapitału społecznego lokalnych grup działania, lecz także ich porównanie w odniesieniu do organizacji pochodzących z dwóch

z czym zmieniono nazwę LGD (nawiązując do usytuowania wszystkich gmin na obszarze Czarnorzecko-Strzyżowskiego Parku Krajobrazowego) [http://www.lgdleader.itl.pl/index.php?option=com_content\&view $=$ article $\&$ id $=100 \&$ Itemid $=102]$. 
zbiorów (wyróżnionych ze względu na wielkość sieci lokalnych grup działania funkcjonujących na ich obszarze), $\mathrm{z}$ drugiego $\mathrm{z}$ nich losowo wybrano grupy (w liczbie równej liczbie grup z pierwszego zbioru), które podlegały pogłębionej analizie i na podstawie których weryfikowano postawione hipotezy. Były to: 1) Ostrzeszowska Lokalna Grupa Działania oraz LGD KOLD (z Wielkopolski), 2) Subregion Magurski, Lasovia, CK Podkarpacie, Partnerstwo dla Ziemi Niżańskiej (z Podkarpacia) oraz 3) LGD Dunajec-Biała, LGD PROKOPARA, Dolina Karpia (z Małopolski). Poziom i strukturę kapitału społecznego tych LGD określono w oparciu o kwestionariusze ankiet wypełnione przez 184 respondentów.

Jak wspomniano, celem podjętych badań było również określenie uwarunkowań kapitału społecznego LGD. Dane zastane (niezbędne do analizy) dotyczyły wszystkich gmin zrzeszonych w opisywanych partnerstwach terytorialnych. W przypadku pierwszego zbioru (w całości zakwalifikowanego do pogłębionych analiz) informacji o cechach gmin (takich, jak poziom aktywności społecznej ich mieszkańców, poziom ich rozwoju gospodarczego, wymiary współpracy między reprezentantami sektora publicznego, społecznego i gospodarczego zamieszkującymi ich obszar) poszukiwano w odniesieniu do 70 jednostek samorządu terytorialnego (wykorzystując opisane we wcześniejszej części pracy narzędzia badawcze). W przypadku drugiego zbioru, z którego wylosowano grupy do pogłębionej analizy, poszukiwano informacji o cechach 15 jednostek samorządu terytorialnego $\mathrm{z}$ województwa małopolskiego, 15 jednostek samorządu terytorialnego z Podkarpacia oraz 14 jednostek samorządu terytorialnego z Wielkopolski (w sumie poszukiwano informacji na temat 44 jednostek samorządu terytorialnego). 
ROZDZIAŁ II

\section{CHARAKTERYSTYKA BADANEJ ZBIOROWOŚCI}

\subsection{Społeczno-demograficzne cechy respondentów a ich członkostwo w LGD}

Analizą objęto wypowiedzi 573 badanych członków LGD z 6 województw. W próbie najliczniej reprezentowani byli członkowie organizacji ulokowanych na obszarze Małopolski, Podkarpacia oraz Wielkopolski. Respondentów z pozostałych województw było mniej (zwłaszcza z woj. lubuskiego) [por. tabela 8].

Tabela 8. Respondenci według województw

\begin{tabular}{|l|c|c|}
\hline \multicolumn{1}{|c|}{ Województwa } & $\begin{array}{c}\text { Liczebność } \\
\text { respondentów }\end{array}$ & $\begin{array}{c}\text { Procent } \\
\text { respondentów }\end{array}$ \\
\hline wielkopolskie & 104 & 18,2 \\
\hline podkarpackie & 183 & 31,9 \\
\hline lubuskie & 25 & 4,4 \\
\hline opolskie & 52 & 9,1 \\
\hline zachodniopomorskie & 26 & 4,5 \\
\hline małopolskie & 183 & 31,9 \\
\hline Ogółem & 573 & 100,0 \\
\hline
\end{tabular}

Źródło: opracowanie własne.

W próbie znalazło się najwięcej przedstawicieli sektora społecznego, najmniej zaś z sektora gospodarczego [tabela 9]. W literaturze przedmiotu wskazuje się (por. rozdział I), że przedsiębiorcy w LGD partycypują w mniejszym zakresie niż przedstawiciele sektora społecznego i publicznego. Często są ich członkami tylko formalnie, rzadziej uczęszczają nawet na walne zebrania osób zrzeszonych w tych organizacjach (odbywające się raz lub dwa razy do roku). Mniejszy udział przedstawicieli sektora gospodarczego w zbiorowości badanej zdaje się potwierdzać ich słabą aktywność. Ponadto ci respondenci najrzadziej (na tle pozostałych) 
byli zrzeszeni w LGD od czasu wdrażania Pilotażowego Programu LEADER+ [tabela 10], co dodatkowo ogranicza możliwość realizacji przez nich w tych strukturach różnych funkcji, zwłaszcza uczestnictwo w pracach zarządu (o czym szerzej w dalszej części pracy).

Warto zauważyć, że członkami LGD od czasu realizacji PPL+ była niewiele ponad połowa badanych $(54,7 \%)$, co świadczy o tym, iż LGD są strukturami dynamicznymi. Niektóre $\mathrm{z}$ osób, wcześniej zaangażowanych $\mathrm{w}$ funkcjonowanie LGD, wycofały się z działalności, inne do nich przystąpiły po zakończeniu PPL+ (co było powodowane m.in. przekształceniami partnerstw - zwiększaniem obszaru ich oddziaływania, a co za tym idzie - włączaniem do ich struktur reprezentantów poszczególnych gmin z trzech sektorów).

Tabela 9. Liczebność respondentów z poszczególnych sektorów

\begin{tabular}{|l|c|c|c|}
\hline \multicolumn{1}{|c|}{$\begin{array}{c}\text { Sektory prezentowane } \\
\text { przez respondentów }\end{array}$} & $\begin{array}{c}\text { Liczebność } \\
\text { respondentów }\end{array}$ & $\begin{array}{c}\text { Procent } \\
\text { respondentów }\end{array}$ & $\begin{array}{c}\text { Procent ważnych } \\
\text { odpowiedzi }\end{array}$ \\
\hline Publiczny & 151 & 26,4 & 28,1 \\
\hline Gospodarczy & 104 & 18,2 & 19,4 \\
\hline Społeczny & 282 & 49,2 & 52,5 \\
\hline Ważne odpowiedzi & 537 & 93,7 & 100,0 \\
\hline Brak danych & 36 & 6,3 & \\
\hline Ogółem & 573 & 100,0 & \\
\hline
\end{tabular}

Źródło: opracowanie własne.

Tabela 10. Staż członkostwa w LGD według sektorów

\begin{tabular}{|c|c|c|c|c|}
\hline & & Członkos & wo w LGD & \\
\hline pr & respondenta & od czasu wdrażania & nie obejmujące wdra- & Ogółem \\
\hline Publiczny & liczebność & 91,0 & 59,0 & 150 \\
\hline r uontezny & $\%$ & 60,7 & 39,3 & 100 \\
\hline & liczebność & 48,0 & 54,0 & 102 \\
\hline Uospodarczy & $\%$ & 47,1 & 52,9 & 100 \\
\hline Snołeczn & liczebność & 150,0 & 132,0 & 282 \\
\hline Społeczny & $\%$ & 53,2 & 46,8 & 100 \\
\hline 1 & liczebność & 289,0 & 240,5 & 534 \\
\hline Ugoientil & $\%$ & 54,1 & 45,9 & 100 \\
\hline
\end{tabular}

Źródło: opracowanie własne. 
Wśród badanych 327 osób pełniło w LGD jakąś funkcję: niespełna 23\% z nich uczestniczyło w pracach zarządu, co trzeci był członkiem rady, nieco powyżej 5\% respondentów należało do komisji rewizyjnej. W próbie ponad połowę stanowiły osoby, które z racji pełnionej funkcji można określić mianem liderów tych organizacji, jej skład rzutuje więc na pozyskane wyniki analizy [tabela 11]. Poziom kapitału społecznego członków tych organizacji może być w związku $\mathrm{z}$ tym nieco zawyżony.

Tabela 11. Funkcje respondentów w LGD

\begin{tabular}{|l|c|c|}
\hline \multicolumn{1}{|c|}{ Wyszczególnienie } & $\begin{array}{c}\text { Liczebność } \\
\text { respondentów }\end{array}$ & $\begin{array}{c}\text { Procent ważnych } \\
\text { odpowiedzi }\end{array}$ \\
\hline Członek zarządu & 126 & 22,5 \\
\hline Członek rady & 170 & 30,3 \\
\hline Członek komisji rewizyjnej & 31 & 5,5 \\
\hline Szeregowy członek & 234 & 41,7 \\
\hline Brak danych & 12 & 100,0 \\
\hline Ogółem & 561 & \\
\hline
\end{tabular}

Źródło: opracowanie własne.

Prace $\mathrm{w}$ ciałach kolegialnych chętniej powierzano osobom, które należały do LGD od czasu realizacji PPL+. Około trzy czwarte członków zarządu nabyło doświadczenie związane $\mathrm{z}$ wdrażaniem podejścia LEADER $\mathrm{w}$ tamtym okresie, podobnie jak prawie trzech na pięciu członków rady oraz niespełna $70 \%$ członków komisji rewizyjnej. Doświadczenie zdobyte w czasie wdrażania PPL+ procentowało i zwiększało szanse sprawowania różnych funkcji w LGD w okresie 2007-2013, aczkolwiek należy zauważyć, że nowi członkowie również zasiadali w tych organach (prawie jedna czwarta członków zarządu przystąpiła do LGD po 2008 r.) - por. tabela 12. Jest to powodowane nie tylko ich osobistymi przymiotami, lecz także składem partnerstw. Dla przykładu, zgodnie z formalnymi regułami, ponad połowa członków zarządu powinna reprezentować sektor społeczny i gospodarczy. Skład tych organów wyznacza również wiele reguł nieformalnych, np. ta, zgodnie z którą każda z gmin należących do partnerstwa powinna mieć swojego reprezentanta we władzach LGD. A zatem, jeśli gmina przystąpiła do partnerstwa po zakończeniu PPL+, jej mieszkańcy (nowi członkowie LGD) zasilali różne jej organy. 
Tabela 12. Staż członkostwa w LGD a pełniona funkcja

\begin{tabular}{|l|l|c|c|c|}
\hline \multirow{2}{*}{\multicolumn{2}{|c|}{ Funkcja w LGD }} & \multicolumn{2}{|c|}{ Członkostwo w LGD } & \multirow{2}{*}{ Ogółem } \\
\cline { 3 - 5 } \multicolumn{2}{|c|}{} & $\begin{array}{c}\text { od czasu wdrażania } \\
\text { PP LEADER+ }\end{array}$ & $\begin{array}{c}\text { nie obejmujące wdra- } \\
\text { żania PP LEADER+ }\end{array}$ & \\
\hline \multirow{2}{*}{$\begin{array}{l}\text { Szeregowy } \\
\text { członek }\end{array}$} & liczebność & 95,0 & 139,0 & 234 \\
\cline { 2 - 5 } & $\%$ & 40,6 & 59,4 & 100 \\
\hline \multirow{2}{*}{ Komisja } & liczebność & 20,0 & 9,0 & 29 \\
\cline { 2 - 5 } & $\%$ & 69,0 & 31,0 & 100 \\
\hline \multirow{2}{*}{ Rada } & liczebność & 96,0 & 74,0 & 170 \\
\cline { 2 - 5 } & $\%$ & 56,5 & 43,5 & 100 \\
\hline \multirow{2}{*}{ Zarząd } & liczebność & 94,0 & 31,0 & 125 \\
\cline { 2 - 5 } & $\%$ & 75,2 & 24,8 & 100 \\
\hline \multirow{2}{*}{ Ogółem } & liczebność & 305,0 & 253,0 & 558 \\
\cline { 2 - 5 } & $\%$ & 54,7 & 45,3 & 100 \\
\hline
\end{tabular}

Źródło: opracowanie własne.

Częściej różne funkcje w tych organizacjach sprawowali mężczyźni ${ }^{1}$. Kobiety przeważały wśród zbiorowości członków zwyczajnych LGD². Należy podkreślić, że zgodnie z formalnymi regułami funkcjonowania LGD (konieczność przestrzegania zasady równości płci) skład ich organów (pod tym względem) powinien być zrównoważony. Fakt, iż w próbie znalazło się więcej mężczyzn niż kobiet nie stanowi przesłanki ku temu, by uznać, że analizowane LGD nie realizują tej zasady. Należy bowiem pamiętać, iż zbiorowość badana nie jest reprezentatywna dla populacji członków tych organizacji [tabela 13].

Tabela 13. Funkcja w LGD a płeć

\begin{tabular}{|l|l|r|r|r|r|c|}
\hline \multicolumn{2}{|c|}{ Płeć } & \multicolumn{4}{c|}{ Funkcja w LGD } & \multirow{2}{*}{ Ogółem } \\
\cline { 3 - 7 } \multicolumn{2}{|c|}{} & $\begin{array}{c}\text { szeregowy } \\
\text { członek }\end{array}$ & komisja & rada & zarząd & \\
\hline \multirow{2}{*}{ Kobiety } & liczebność & 117,0 & 8,0 & 59,0 & 52,0 & 236 \\
\cline { 2 - 7 } & $\%$ & 49,6 & 3,4 & 25,0 & 22,0 & 100 \\
\hline \multirow{2}{*}{ Mężczyźni } & liczebność & 113,0 & 22,0 & 110,0 & 74,0 & 319 \\
\cline { 2 - 7 } & $\%$ & 35,4 & 6,9 & 34,5 & 23,2 & 100 \\
\hline \multirow{2}{*}{ Ogółem } & liczebność & 230,0 & 30,0 & 169,0 & 126,0 & 555 \\
\cline { 2 - 7 } & $\%$ & 41,4 & 5,4 & 30,5 & 22,7 & 100 \\
\hline
\end{tabular}

Źródło: opracowanie własne.

${ }^{1}$ Mając na uwadze fakt, że członkowie „funkcyjni” częściej są zmotywowani do uczestnictwa w różnych posiedzeniach LGD, nie dziwi to, iż w próbie przeważali mężczyźni (stanowiąc około $58 \%$ respondentów).

${ }^{2}$ Ogółem członkowie zwyczajni LGD stanowili około $42 \%$ badanych. 
Sprawowaniu różnych funkcji w tych organizacjach sprzyjał bardziej zaawansowany wiek badanych. Osoby najmłodsze (zwłaszcza w wieku 18-24 lata) w najmniejszym stopniu uczestniczyły w pracach zarządu [tabela 14].

Tabela 14. Funkcje w LGD a wiek

\begin{tabular}{|l|l|r|r|r|r|r|}
\hline \multirow{2}{*}{\multicolumn{2}{|c|}{ Kategorie wieku }} & \multicolumn{4}{c|}{ Funkcja w LGD } & \multirow{2}{*}{ Ogółem } \\
\cline { 3 - 7 } & $\begin{array}{c}\text { szeregowy } \\
\text { członek }\end{array}$ & komisja & rada & zarząd & \\
\hline \multirow{2}{*}{$18-24$} & liczebność & 5,0 & - & 1,0 & - & 6 \\
\cline { 2 - 7 } & $\%$ & 83,3 & - & 16,7 & - & 100 \\
\hline \multirow{2}{*}{$25-34$} & liczebność & 52,0 & 3,0 & 10,0 & 10,0 & 75 \\
\cline { 2 - 7 } & $\%$ & 69,3 & 4,0 & 13,3 & 13,3 & 100 \\
\hline \multirow{3}{*}{$35-44$} & liczebność & 37,0 & 8,0 & 46,0 & 23,0 & 114 \\
\cline { 2 - 7 } & $\%$ & 32,5 & 7,0 & 40,4 & 20,2 & 100 \\
\hline \multirow{3}{*}{$45-54$} & liczebność & 50,0 & 11,0 & 54,0 & 41,0 & 156 \\
\cline { 2 - 7 } & $\%$ & 32,1 & 7,1 & 34,6 & 26,3 & 100 \\
\hline \multirow{2}{*}{$55-64$} & liczebność & 47,0 & 6,0 & 45,0 & 33,0 & 131 \\
\cline { 2 - 7 } & $\%$ & 35,9 & 4,6 & 34,4 & 25,2 & 100 \\
\hline \multirow{2}{*}{$65+$} & liczebność & 17,0 & 1,0 & 4,0 & 14,0 & 36 \\
\cline { 2 - 7 } & $\%$ & 47,2 & 2,8 & 11,1 & 38,9 & 100 \\
\hline \multirow{2}{*}{ Ogółem } & liczebność & 208,0 & 29,0 & 160,0 & 121,0 & 518 \\
\cline { 2 - 7 } & $\%$ & 40,2 & 5,6 & 30,9 & 23,4 & 100 \\
\hline
\end{tabular}

Źródło: opracowanie własne.

Tych osób w próbie znalazło się najmniej, podobnie jak osób w wieku 65+, $z$ tą jednak różnicą, że najstarsi członkowie LGD zasiadali w ich zarządach. Aktywność najmłodszych badanych zapewne ograniczało kontynuowanie nauki, rozpoczynanie pracy zawodowej, wychowywanie małych dzieci. Ponadto literatura przedmiotu wskazuje, iż LGD są strukturami w wysokim stopniu sprofesjonalizowanymi (por. rozdział 1). Młodsze osoby, nawet jeśli dysponują relatywnie wysokim poziomem kapitału ludzkiego (chociażby z racji wykształcenia), nie mają jeszcze doświadczenia zawodowego, które mogą wykorzystać (zwłaszcza w pracy w zarządzie czy radzie), ale i sieci kontaktów, które pozwalałyby na uruchomienie posiadanych zasobów kapitału ludzkiego [por. tabela 15]. 
Tabela15. Respondenci według wieku

\begin{tabular}{|l|c|c|}
\hline Kategorie wieku & $\begin{array}{c}\text { Liczebność } \\
\text { respondentów }\end{array}$ & $\begin{array}{c}\text { Procent ważnych } \\
\text { odpowiedzi }\end{array}$ \\
\hline $18-24$ & 6 & 1,1 \\
\hline $25-34$ & 76 & 14,4 \\
\hline $35-44$ & 114 & 21,6 \\
\hline $45-54$ & 158 & 30,0 \\
\hline $55-64$ & 135 & 25,6 \\
\hline $65+$ & 38 & 7,2 \\
\hline Brak danych & 46 & \\
\hline Ogółem & 527 & 100,0 \\
\hline
\end{tabular}

Źródło: opracowanie własne.

W badanej zbiorowości znalazły się w największym odsetku osoby w wieku 45-54 oraz 55-64 lata, a więc te, które najczęściej były u szczytu swojej kariery zawodowej (lub właśnie ją kończyły). Mając na uwadze fakt, że większoóć respondentów $(68,4 \%)$ mieszkała w swojej miejscowości od urodzenia, można stwierdzić, iż mogli oni wykazać się dotychczasowym doświadczeniem zawodowym (być może) przydatnym w działalności w LGD. Ponadto wykonując obowiązki, np. pracownika urzędu gminy, GOK czy członka OSP byli znani mieszkańcom gmin wchodzących w skład partnerstwa, dysponowali wiedzą na temat specyfiki miejsca zamieszkania, zwłaszcza że większość z nich pracę zawodową łączyła z pracą społeczną (o czym szerzej w rozdziale 3 niniejszej pracy).

Tabela 16. Funkcja w LGD a wykształcenie

\begin{tabular}{|l|l|r|r|r|r|r|}
\hline \multirow{2}{*}{\multicolumn{2}{|c|}{ Wykształcenie }} & \multicolumn{4}{c|}{ Funkcja w LGD } & \multirow{2}{*}{ Ogółem } \\
\cline { 3 - 7 } & $\begin{array}{c}\text { szeregowy } \\
\text { członek }\end{array}$ & komisja & rada & \multirow{2}{*}{ zarząd } & \\
\hline \multirow{2}{*}{ Poniżej średniego } & liczebność & 29,0 & 5,0 & 26,0 & 11,0 & 71 \\
\cline { 2 - 7 } & $\%$ & 40,8 & 7,0 & 36,6 & 15,5 & 100 \\
\hline \multirow{2}{*}{ Średnie } & liczebność & 77,0 & 11,0 & 33,0 & 30,0 & 151 \\
\cline { 2 - 7 } & $\%$ & 51,0 & 7,3 & 21,9 & 19,9 & 100 \\
\hline \multirow{2}{*}{ Wyższe } & liczebność & 125,0 & 14,0 & 108,0 & 85,0 & 332 \\
\cline { 2 - 7 } & $\%$ & 37,7 & 4,2 & 32,5 & 25,6 & 100 \\
\hline \multirow{2}{*}{ Ogółem } & liczebność & 231,0 & 30,0 & 167,0 & 126,0 & 554 \\
\cline { 2 - 6 } & $\%$ & 41,7 & 5,4 & 30,1 & 22,7 & 100 \\
\hline
\end{tabular}

Źródło: opracowanie własne. 
Badani członkowie LGD cechowali się wysokim poziomem wykształcenia - średnim legitymowało się około $28 \%$ z nich ${ }^{3}$, zaś wyższym $59,4 \%{ }^{4}$. To osoby z wyższym wykształceniem najczęściej zasiadały w zarządach LGD (najrzadziej wchodząc w skład zbiorowości członków zwyczajnych) - por. tabela 16.

Zdecydowana większość respondentów była aktywna na rynku pracys. Najczęściej wykonywali oni prace umysłowe (około 22\% reprezentowało kadry zarządzające). W próbie znalazło się najmniej pracowników fizycznych oraz właścicieli gospodarstw rolnych [tabela 17].

Tabela 17. Respondenci według kategorii społeczno-zawodowych

\begin{tabular}{|l|c|c|}
\hline \multicolumn{1}{|c|}{ Kategoria zawodowa } & Liczebność respondentów & $\begin{array}{c}\text { Procent ważnych } \\
\text { odpowiedzi }\end{array}$ \\
\hline Kadry kierownicze & 95 & 21,5 \\
\hline Specjaliści (inteligencja) & 83 & 18,8 \\
\hline $\begin{array}{l}\text { Pracownicy umysłowi (biurowi, } \\
\text { handlu i usług) }\end{array}$ & 164 & 37,2 \\
\hline Pracownicy fizyczni & 29 & 6,6 \\
\hline Właściciele gospodarstw rolnych & 27 & 6,1 \\
\hline Właściciele firm & 43 & 9,8 \\
\hline Ważne odpowiedzi & 441 & 100,0 \\
\hline Brak danych & 44 & \\
\hline Nie pracuje & 88 & \\
\hline Ogółem & 573 & \\
\hline
\end{tabular}

Źródło: opracowanie własne.

A zatem, relatywnie wysoki poziom wykształcenia respondentów w połączeniu z pozycją zawodową zdaje się świadczyć o ich wysokim poziomie kapitału ludzkiego ${ }^{6}$. Nie oznacza to, że wszyscy członkowie mogą wykorzystać swoje zasoby w jednakowym stopniu. Największe szanse na to mają ci, którzy przystąpili do tych organizacji w czasie realizacji PPL+, co mogło zadecydować o ich wyborze do tak znaczących organów, jak zarząd i rada. W strukturze zbiorowości

${ }^{3}$ W kategorii osób ze średnim wykształceniem znalazły się także osoby z pomaturalnym wykształceniem $(6,2 \%)$ oraz nieukończonym wyższym (4,3\%).

${ }^{4}$ Niespełna $13 \%$ badanych cechowało się wykształceniem niższym niż średnie.

${ }^{5}$ Wśród pracujących większość osób $(89,5 \%)$ jest zatrudniona poza rolnictwem.

${ }^{6}$ Wśród osób nieaktywnych (których w próbie było niespełna $18 \%$ ) dominowali emeryci (55,8\% ogółu tej zbiorowości) i renciści (24,2\% ogółu). Osoby bezrobotne w najmniejszym stopniu były reprezentowane w zbiorowości członków LGD (18,9\% osób nieaktywnych zawodowo stanowili bezrobotni, co potwierdza zaobserwowane w wielu badaniach prawidłowości - wykluczenie z rynku pracy najczęściej pozostaje w związku z innymi wymiarami wykluczenia społecznego, w tym z wykluczeniem z życia publicznego. 
badanej zwraca uwagę niewielki odsetek najmłodszych respondentów. Wskazuje ona również na niewielkie zaangażowanie $\mathrm{w}$ realizację podejścia LEADER reprezentantów sektora gospodarczego. Wydaje się, że mimo upływu lat niewiele udało się zrobić (zwłaszcza liderom LGD), by zaangażować reprezentantów tych dwóch kategorii społecznych w działania społeczne podejmowane na obszarze partnerstwa.

\subsection{Aktywność polityczna badanych}

Chcąc scharakteryzować i ocenić stopień zainteresowania i zaangażowania w politykę członków lokalnych grup działania, należy wyjść od ustaleń dotyczących społeczeństwa polskiego w ogóle, wynikających bądź to z badań Europejskiego sondażu społecznego z 2008 r., bądź też z badań Diagnozy społecznej z 2011 r.7 Jak wynika z tych badań (ESS), Polacy pod względem zainteresowania i zaangażowania w politykę wypadają poniżej średniej europejskiej. Podobnie jest z udziałem w wyborach parlamentarnych, samorządowych czy prezydenckich. Co więcej, pod względem frekwencji w wyborach do Parlamentu Europejskiego uplasowaliśmy się w 2009 r. na trzecim miejscu od końca, mimo że należymy do największych w UE entuzjastów Parlamentu Europejskiego, który darzymy dwukrotnie większym zaufaniem niż Sejm. Jak stwierdzają autorzy raportu, nawet przy pominięciu krajów, w których udział w wyborach jest administracyjnie obowiązkowy (np. Belgii i Luksemburga) i tak aktywność polityczna Polaków i ogólnie rzecz ujmując aktywność obywatelska (o czym mówią wskaźniki kapitału społecznego) jest bardzo niska. Z badań ESS wynika, że bardzo duże i znaczne zainteresowanie polityką deklarowało $42 \%$ społeczeństwa polskiego, co plasowało nas wśród 28 krajów Europy (członków UE) na 7 miejscu od końca (najgorszy wynik - Hiszpania - 26\% zainteresowanych; najlepszy Dania - 72\% i Holandia - 67\%). Jednocześnie tylko 2,6\% Polaków deklarowało udział w partiach i ruchach społecznych (action group) - 6 miejsce od końca wśród 28 państw europejskich; najlepszy wynik dotyczył Cypru $-8,7 \%$, najgorszy Portugalii - 1,3\% i Łotwy $-1,1 \%$.

Ponad połowa badanych $(53,6 \%)$ zadeklarowała bardzo duży i duży poziom zainteresowania polityką, co pozwala stwierdzić, że to zainteresowanie jest relatywnie wyższe niż w badaniach ESS. Tylko 5,6\% członków lokalnych grup działania stwierdziło, że to zainteresowanie jest niewielkie, a 3,0\%, że w ogóle nie interesuje się polityką ${ }^{8}$ [por. tabela 18].

7 Diagnoza społeczna 2011a, 2011 b.

${ }^{8} \mathrm{~W}$ wielu badaniach dotyczących poziomu zainteresowania polityką i aktywności politycznej wskazuje się na różnicujący wpływ podstawowych zmiennych społeczno-demograficznych: płci, wieku, wykształcenia czy charakteru wykonywanej pracy. Stopień zróżnicowania poziomu zainteresowania polityką wśród członków LGD ze względu na płeć, wiek, wykształcenie, kategorie społeczno-zawodowe obrazują tabele 7.1-7.4 w załączniku 7. aneksu. 
Tabela 18. Poziom zainteresowania polityką

\begin{tabular}{|c|c|c|c|c|}
\hline $\begin{array}{c}\text { Poziom zainteresowania } \\
\text { polityką }\end{array}$ & $\begin{array}{l}\text { Liczebność } \\
\text { respondentów }\end{array}$ & Procent & $\begin{array}{c}\text { Procent ważnych } \\
\text { odpowiedzi }\end{array}$ & $\begin{array}{c}\text { Procent } \\
\text { skumulowany }\end{array}$ \\
\hline $\begin{array}{l}\text { Bardzo duży - śledzę prawie } \\
\text { wszystko, co się dzieje w po- } \\
\text { lityce }\end{array}$ & 121 & 21,1 & 21,4 & 21,4 \\
\hline $\begin{array}{l}\text { Duży - dość uważnie śledzę to, } \\
\text { co dzieje się w polityce }\end{array}$ & 182 & 31,8 & 32,2 & 53,6 \\
\hline $\begin{array}{l}\text { Średni - śledzę jedynie główne } \\
\text { wydarzenia w polityce }\end{array}$ & 213 & 37,2 & 37,7 & 91,3 \\
\hline $\begin{array}{l}\text { Niewielki - umykają uwadze } \\
\text { nawet główne wydarzenia }\end{array}$ & 32 & 5,6 & 5,7 & 97,0 \\
\hline $\begin{array}{l}\text { Brak zainteresowania - w ogó- } \\
\text { le nie interesuję się tym, co } \\
\text { dzieje się w polityce }\end{array}$ & 17 & 3,0 & 3,0 & 100,0 \\
\hline Ważne odpowiedzi & 565 & 98,6 & 100,0 & \\
\hline Brak danych & 8 & 1,4 & & \\
\hline Ogółem & 573 & 100,0 & & \\
\hline
\end{tabular}

Źródło: opracowanie własne.

Ci działacze LGD, którzy deklarowali niewielkie zainteresowanie polityką lub całkowity jego brak, uzasadniając takie odniesienia do tej sfery życia publicznego odwoływali się do dwóch rodzajów tych uzasadnień; jedno z nich miało ogólnikową i niewiele mówiącą treść nacechowaną emocjonalnie i sprowadzało się do wyrażenia: „Nie lubię polityki”; drugie odnosiło się do oceny polityków jako osób, które podejmując działania polityczne dbają tylko o swoje interesy. Ten mało zniuansowany i ogólnikowy rodzaj uzasadnień mieści się jednak w dominującym nurcie argumentów, które przywołują Polacy wtedy, kiedy chcą podkreślić swój dystans do polityki, wynikający głównie z alienacji politycznej. Należy jednak pamiętać, że w badanej zbiorowości LGD, w porównaniu z wynikami badań reprezentatywnych, i tak występuje większy odsetek osób polityką zainteresowanych.

Powszechnie uważa się, że udział w wyborach jest najbardziej podstawowym doświadczeniem obywatelskim, zaś w wyborach samorządowych - wyrazem zaangażowania w sprawy własnych społeczności lokalnych i regionalnych. W oparciu o Diagnozę społeczną $2011^{9}$ można stwierdzić, iż deklarowany udział w ostatnich wyborach samorządowych (z 2010 r.) wynosił 68,3\%. Jednak według danych podanych przez Państwową Komisję Wyborczą (www.pkw.gov.pl), rzeczywista frekwencja była o wiele niższa i wynosiła 47,3\%. Udział w wyborach

${ }^{9}$ Diagnoza społeczna 2011a, 2011b: 282. 
parlamentarnych, które odbyły się w 2007 r. zadeklarowało 66\% badanych, przy 54\% frekwencji rzeczywistej. Jak piszą autorzy Diagnozy społecznej, zawyżanie frekwencji wyborczej jest w sondażach regułą; udział w wyborach niezależnie od typu wyborów i frekwencji rzeczywistej deklaruje mniej więcej dwie trzecie badanych. Tę istotną uwagę badawczą należy mieć na względzie głównie po to, aby brać poprawkę na to, iż część deklarowanych zachowań, jak choćby udział w wyborach, jest wyraźnie zawyżanych. Różnice wynikające z porównań deklaracji dotyczących potencjalnego zaangażowania wyborczego pochodzące $\mathrm{z}$ badań sondażowych (zarówno z ESS, jak i z kolejnych edycji Diagnozy społecznej) z rzeczywistym udziałem w wyborach (dane Państwowej Komisji Wyborczej) sięgają w Polsce 20 punktów procentowych (w 2011 r. 66\% respondentów przyznało, że brało udział w tych wyborach, zaś dane PKW mówiły o frekwencji na poziomie 47,3\%). Jak zatem przedstawia się deklarowany udział członków LGD w trzech typach wyborów występujących w Polsce?

Deklarowana przez członków LGD frekwencja wyborcza w ostatnich wyborach - prezydenckich, samorządowych czy parlamentarnych - jest wyższa niż dla całej populacji wyborców w Polsce [por. tabele 19-21].

Tabela 19. Udział w ostatnich wyborach prezydenckich

\begin{tabular}{|l|c|c|c|}
\hline Wybory prezydenckie - udział & $\begin{array}{c}\text { Liczebność } \\
\text { respondentów }\end{array}$ & Procent & $\begin{array}{c}\text { Procent ważnych } \\
\text { odpowiedzi }\end{array}$ \\
\hline Tak & 445 & 77,7 & 78,3 \\
\hline Nie & 123 & 21,5 & 21,7 \\
\hline Ważne odpowiedzi & 568 & 99,1 & 100,0 \\
\hline Brak danych & 5 & 0,9 & \\
\hline Ogółem & 573 & 100,0 & \\
\hline
\end{tabular}

Źródło: opracowanie własne.

Tabela 20. Udział w wyborach samorządowych

\begin{tabular}{|l|c|c|c|}
\hline Wybory samorządowe - udział & $\begin{array}{c}\text { Liczebność } \\
\text { respondentów }\end{array}$ & Procent & $\begin{array}{c}\text { Procent ważnych } \\
\text { odpowiedzi }\end{array}$ \\
\hline Tak & 504 & 88,0 & 88,4 \\
\hline Nie & 66 & 11,5 & 11,6 \\
\hline Ważne odpowiedzi & 570 & 99,5 & 100,0 \\
\hline Brak danych & 3 & 0,5 & \\
\hline Ogółem & 573 & 100,0 & \\
\hline
\end{tabular}

Źródło: opracowanie własne. 
Tabela 21. Udział w wyborach parlamentarnych

\begin{tabular}{|l|c|c|c|}
\hline Wybory parlamentarne-udział & $\begin{array}{c}\text { Liczebność } \\
\text { respondentów }\end{array}$ & Procent & $\begin{array}{c}\text { Procent ważnych } \\
\text { odpowiedzi }\end{array}$ \\
\hline Tak & 424 & 74,0 & 74,6 \\
\hline Nie & 144 & 25,1 & 25,4 \\
\hline Ważne odpowiedzi & 568 & 99,1 & 100,0 \\
\hline Brak danych & 5 & 0,9 & \\
\hline Ogółem & 573 & 100,0 & \\
\hline
\end{tabular}

Źródło: opracowanie własne.

Najwyższa, deklarowana przez członków LGD, frekwencja wyborcza dotyczyła wyborów samorządowych, w których uczestnictwo deklarowało aż 88,0\% badanych; różnice między frekwencją w wyborach prezydenckich $(77,7 \%)$ czy parlamentarnych (74,0\%) były zaś niewielkie. Można zatem zaryzykować twierdzenie, że skoro udział w wyborach deklaruje około dwie trzecie uprawionych obywateli, to te wysokie deklaracje w przypadku członków LGD mogą sugerować, że rzeczywiście ich frekwencja wyborcza w ostatnich trzech typach wyborów była relatywnie wysoka ${ }^{10}$.

Rodzajem większego zaangażowania w politykę w ogóle lub zaangażowania na rzecz konkretnego kandydata może być m.in. udział w przygotowaniu kampanii wyborczej (wykonywanie prac na rzecz jakiejś partii czy komitetu wyborczego). Z deklaracji członków LGD wynika, że ponad połowa spośród nich (324 $-57,7 \%$ ) była w jakiś sposób zaangażowana w przygotowania wyborcze. Mogło

${ }^{10}$ Istotnym, różnicującym kryterium uczestnictwa w wyborach było wykształcenie i przynależność do kategorii społeczno-zawodowej. W badaniach prowadzonych wśród członków LGD tendencja ta również wystąpiła, ale - co ciekawe - zmierzała w nieco innym kierunku niż w badaniach sondażowych CBOS-u czy Diagnozy społecznej. Otóż w wyborach prezydenckich i parlamentarnych najwyższy poziom deklarowanego uczestnictwa dotyczył osób z wykształceniem poniżej średniego (odpowiednio: $81,1 \%$ i 77,0\%); najniższy - osób z wykształceniem wyższym w odniesieniu do wyborów prezydenckich $(77,2 \%)$ i z wykształceniem średnim w odniesieniu do wyborów parlamentarnych $(71,2 \%)$. Jeśli chodzi o wybory samorządowe, to tutaj, tak jak w innych reprezentatywnych badaniach, najwyższą frekwencję deklarowały osoby z wyższym wykształceniem (92,5\%), najniższą zaś osoby z wykształceniem średnim (81,0\%), ale nie niższym niż średnie. Uwzględniając zaś podział respondentów na kategorie zawodowe, nie można stwierdzić żadnej prawidłowości, poza tą, że najwyższy udział w wyborach prezydenckich deklarowali właściciele gospodarstw rolnych $(96,2 \%)$, najniższy kadra kierownicza $(72,6 \%)$. Ta ostatnia kategoria zawodowa była jednak bardzo aktywna w ostatnich wyborach samorządowych, deklarując prawie stuprocentową frekwencję $(96,8 \%)$; najmniejsze zainteresowanie tymi wyborami wykazali zarazem właściciele firm (deklarowana frekwencja na poziomie $81,4 \%$ ). W odniesieniu do wyborów parlamentarnych wystąpiła jeszcze inna tendencja - najwyższy w nich udział deklarowali właściciele gospodarstw rolnych (80,8\%) i pracownicy fizyczni (79,3\%). Przywoływane wielkości wskazań nie różnią się jednak na tyle istotnie, aby można było stwierdzić jakieś wyraźne prawidłowości. 
to mieć, oczywiście, różny charakter, jednak jest wskaźnikiem choćby zainteresowania tym, aby jakiś kandydat miał szansę na wygraną ${ }^{11}$.

Badani, przystępując do LGD, kierowali się różnymi motywami, również takimi, które można określić jako zainteresowanie tym, co się dzieje na terenie ich gminy (o czym szerzej w rozdziale III). Pojawia się zatem pytanie, jak wielu spośród nich zastanawiało się nad tym, by kandydować w wyborach samorządowych? Z analizy danych empirycznych wynika, że ponad połowa spośród badanych (296 osób - 51,9\%) zastanawiała się nad braniem udziału w wyborach w charakterze kandydata. Warto dodać, że prawie jedna czwarta spośród nich (129 osób - 22,5\%) myślała o objęciu funkcji wójta/burmistrza ${ }^{12}$.

Jakie zatem były dominujące argumenty zarówno tych, którzy zastanawiali się nad kandydowaniem w wyborach samorządowych, jak i tych, którzy takiej decyzji nie brali pod uwagę? Jeśli chodzi o osoby zainteresowane funkcjonowaniem w strukturach samorządowych, wyróżnić można trzy dominujące rodzaje argumentów: chęć działania na rzecz innych oraz dobra wspólnego, jakim jest społeczność lokalna (gmina/wieś), chęć posiadania wpływu (niekiedy tylko poczucia wpływu) na treść i przebieg procesu podejmowania decyzji dotyczących rozwoju gminy (możliwość współdecydowania), chęć zmiany sposobu rządzenia w gminie (głównie w odniesieniu do sfery finansów i inwestycji). Nieco rzadziej przywoływane były argumenty wyprowadzane z cech osobistych respondentów (,jestem osobą aktywną, chcę zmieniać rzeczywistość wokół siebie”), z przekonania o zaufaniu w środowisku lokalnym, a nawet $\mathrm{z}$ tego, że pracując w samorządzie można mieć większe dochody. Incydentalnie przywoływany był argument dotyczący młodego wieku członka LGD, który - zdaniem tych badanych - jest

${ }^{11}$ Istotnym czynnikiem różnicującym czynny udział członków LGD w przygotowywaniu kampanii wyborczych lub wykonywanie innych prac na rzecz kandydata jakieś partii czy komitetu wyborczego był wiek. Najmniejsze odsetki osób angażujących się kiedykolwiek w takie prace występują wśród najmłodszych członków LGD: wśród osób w wieku od 18 do 4 lat - 33,3\% oraz w wieku od 25-34 lata - 42,1\%. Największe zaangażowanie występowało zaś wśród najstarszych kategorii wiekowych: $55-64$ lata - 72,0\% oraz 65 i więcej - 68,6\%, co jest do pewnego stopnia zrozumiałe, biorąc zwłaszcza pod uwagę nieco odmienne uwarunkowania składające się na przebieg kampanii wyborczych w środowiskach wiejskich.

12 Ważną zmienną różnicującą gotowość uczestnictwa we władzach samorządowych okazało się wykształcenie; zarówno w odniesieniu do zamiaru kandydowania w wyborach samorządowych w ogóle, jak i na urząd wójta/burmistrza. Spośród osób z wykształceniem wyższym zamiar kandydowania w przyszłych wyborach samorządowych deklarowało aż $60,4 \%$ badanych, a na urząd wójta/burmistrza prawie jedna trzecia spośród nich (32,7\%). Spośród osób z wykształceniem niższym niż średnie tylko $32,4 \%$ w samych wyborach i $4,1 \%$ w wyborach na urząd wójta/burmistrza. Czynnikiem różnicującym była również przynależność do określonych kategorii zawodowych. Zamiar kandydowania w wyborach samorządowych najczęściej deklarowała kadra kierownicza (76,8\%), najrzadziej zaś pracownicy umysłowi (biurowi, handlu i usług - 40,5\% oraz właściciele firm 41,9\%). Jeśli chodzi o zamiar ubiegania się o funkcję wójta/burmistrza, to zdecydowanie najczęściej myślała o tym ponad połowa kadry kierowniczej (53,2\%) - członków LGD i tylko 7,4\% właścicieli gospodarstw rolnych i właścicieli firm $(14,0 \%)$. 
atutem, gdyż pozwala spojrzeć ,ś́wieżym okiem” na kierunki rozwoju gminy. W uzasadnieniach padały często dość podniosłe określenia typu: „chcę mieć zadbaną i rozwiniętą gminę, chcę dbać o rozwój mojej małej ojczyzny", za którymi z pewnością stały tak odczuwane motywacje.

Niewiele mniejszy odsetek badanych członków LGD nie zastanawiał się nigdy nad tym, by kandydować w wyborach samorządowych i ubiegać się o funkcję radnego. Tutaj rodzaj przywoływanych argumentacji również można ująć w trzy dominujące grupy: brak odpowiednich predyspozycji - cech osobowościowych („nie mam osobowości przywódcy”), deficyty o charakterze społeczno-demograficznym (zbyt młody/zbyt zaawansowany wiek, brak odpowiedniego wykształcenia, odpowiedniej wiedzy, doświadczenia życiowego, stażu pracy) oraz brak zainteresowania polityką. W pojedynczych wypowiedziach badani odwoływali się również do argumentu związanego z brakiem czasu czy dużych pieniędzy na prowadzenie kampanii wyborczej, do argumentu, że można wiele zrobić dla lokalnego środowiska nie funkcjonując w samorządzie oraz do tego, że brak w lokalnym środowisku siły politycznej, która mogłaby poprzeć starania w wyborach samorządowych.

Warto zatem w tym miejscu zatrzymać się na argumencie związanym z brakiem zainteresowania polityką; padały często określenia bardzo mocne - „polityką się brzydzę, mam inne priorytety niż cyniczne, polityczne zagrywki, polityka mnie nie interesuje". Jest to ten rodzaj argumentacji, z której, w sposób pośredni, możemy wnioskować, że część członków LGD, tak jak (co wynika z innych badań), przedstawicieli innych kategorii społecznych, postrzega funkcjonowanie struktur samorządowych przede wszystkim w kategoriach politycznych - tak jak struktury parlamentarne.

Aktywność obywatelska na poziomie gminy, zarówno ta sformalizowana, jak i niesformalizowana, bardziej lub mniej zindywidualizowana, zależy w znacznym stopniu od tego, jak oceniana jest jakość sprawowania władzy samorządowej. Stąd też interesujące jest przede wszystkim to, jak oceniane są działania radnych, czyje (zdaniem członków LGD) reprezentują interesy. Dalej, interesujące jest, jakie propozycje zmian badani chcieliby wprowadzić do sposobu funkcjonowania władzy lokalnej oraz to, jak oceniają możliwości własnego wpływu na decyzje władz lokalnych? Od wiodących tendencji pojawiających się w tych opiniach zależy bowiem, w znacznym stopniu, gotowość i skala zaangażowania członków LGD w podejmowanie (we współpracy z mieszkańcami gminy) różnego rodzaju działań obywatelskich, służących rozwiązywaniu problemów środowiska lokalnego. Członkowie LGD mają wystarczający potencjał organizacyjny i doświadczenia wynikające $\mathrm{z}$ samego faktu funkcjonowania w partnerstwach terytorialnych.

Tylko niewiele ponad jedna trzecia badanych $(37,1 \%)$ deklaruje przekonanie, że radni z ich gmin reprezentują przede wszystkim oczekiwania i interesy wszystkich mieszkańców gminy; prawie jedna trzecia $(29,2 \%)$, że tylko oczekiwania i interesy osób, które na nich głosowały; prawie jedna piąta $(16,2 \%)$, że przede 
wszystkim oczekiwania i interesy własnej partii, której ci radni są członkami lub których dana partia zgłosiła na kandydatów w kampanii wyborczej. Warto również wspomnieć, że aż 13,3\% badanych było przekonanych o tym, że radni z ich gminy realizują przede wszystkim własne oczekiwania i interesy, a 4,2\% badanych - że przede wszystkim oczekiwania i interesy krewnych i znajomych. Tym samym możemy stwierdzić, iż ocena władzy samorządowej w gminach, w których funkcjonują członkowie LGD, nie jest zbyt wysoka ${ }^{13}$.

Członkowie LGD z powodu swojej aktywności w środowisku lokalnym/ gminnym nie tylko współpracują z członkami samorządu, radnymi, których sposób działania dość różnie oceniają i jego ścisłym kierownictwem, lecz także mają dość sprecyzowane poglądy na temat koniecznych zmian w sposobie funkcjonowania władz lokalnych. Należy przypuszczać, iż systematyczna i w miarę bezpośrednia obserwacja działań tej władzy pozwala im na wypracowanie zazwyczaj merytorycznej opinii. Tym bardziej, że (jak to zaznaczono wcześniej) ponad połowa spośród badanych $(51,9 \%)$ rozważała możliwość kandydowania w wyborach samorządowych, a nieco więcej niż jedna czwarta $(22,5 \%)$ myślała o objęciu w przyszłości funkcji wójta/burmistrza.

${ }^{13}$ Uwzględniając zmienną płci, można stwierdzić, że nie różnicuje ona wyraźnie formułowanych opinii, choć mężczyźni mają bardziej pozytywne opinie; tak np. mężczyźni (39,3\%) częściej niż kobiety $(34,8 \%)$ są zdania, że radni realizują przede wszystkim oczekiwania i interesy wszystkich mieszkańców gminy i rzadziej niż kobiety, że realizują przede wszystkim oczekiwania i interesy swojej partii czy krewnych lub znajomych [zob. załącznik 7, tabela $7.5 \mathrm{w}$ aneksie]. Przy czym osoby młode, do 34. roku życia, częściej są krytyczne wobec radnych, częściej wskazując, że radni w swojej codziennej pracy częściej reprezentują oczekiwania i interesy osób, które na nich głosowały i swoje własne. Osoby najstarsze są najbardziej przychylne władzy samorządowej w osobach radnych, np. 50\% wskazuje na to, iż radni reprezentują przede wszystkim interes wszystkich mieszkańców gminy [zob. załącznik 7, tabela $7.6 \mathrm{w}$ aneksie]. Jednak zróżnicowanie opinii w omawianym obszarze jest największe, jeśli uwzględnimy wykształcenie. I tak wśród osób z wykształceniem poniżej średniego ponad połowa badanych $(54,5 \%)$ była zdania, że radni przede wszystkim reprezentują oczekiwania i interesy wszystkich mieszkańców gminy; z wykształceniem średnim - 39,4\%, a z wykształceniem wyższym tylko 33,0\%. Jednocześnie to osoby z wykształceniem niższym niż średnie najczęściej wskazywały na to, że radni przede wszystkim reprezentują własne oczekiwania i interesy (25\% wskazań) [zob. załącznik 7, tabela $7.7 \mathrm{w}$ aneksie]. Jeśli zaś uwzględnimy zmienną „kategorie zawodowe”, to okazuje się, że trzy kategorie wyraźnie różnią się nie tylko między sobą, lecz także w porównaniu z pozostałymi kategoriami zawodowymi: kadra kierownicza, właściciele gospodarstw rolnych i specjaliści (inteligencja). Kadra kierownicza $(31,6 \%)$ oraz specjaliści $(30,8 \%)$ relatywnie najrzadziej wskazują na to, że radni w ich gminach realizują przede wszystkim oczekiwania i interesy wszystkich mieszkańców gminy. Z kolei aż połowa badanych właścicieli gospodarstw rolnych tak postrzega pracę radnych. Specjaliści najczęściej $(21,2 \%)$ spośród wszystkich kategorii wskazują z kolei na to, że radni realizują przede wszystkim oczekiwania i interesy swojej partii; jednocześnie jedna czwarta właścicieli gospodarstw rolnych jest przekonana o tym, że radni realizują przede wszystkim swoje oczekiwania i interesy [zob. załącznik 7, tabela $7.8 \mathrm{w}$ aneksie]. Kiedy jednak spojrzymy na zróżnicowanie opinii na temat tego, czyje przede wszystkim oczekiwania i interesy reprezentują radni w gminach członków LGD z punktu widzenia tego, czy badany pracuje zawodowo czy nie, to różnice procentowe w deklarowanych opiniach są bardzo małe. 
Potrzebę wprowadzenia zmian w sposobie funkcjonowania władzy lokalnej deklarowało 43,5\% członków LGD. Jednak zdecydowana większość badanych $\mathrm{z}$ tej kategorii nie miała sprecyzowanych poglądów na temat tego, co przede wszystkim by zmieniła [por. tabela 22].

Tabela 22. Deklaracja potrzeby zmian sposobu funkcjonowania władzy lokalnej

\begin{tabular}{|l|c|c|c|}
\hline \multicolumn{1}{|c|}{$\begin{array}{c}\text { Potrzeba wprowadzenia zmian } \\
\text { w sposobie funkcjonowania } \\
\text { władzy lokalnej }\end{array}$} & $\begin{array}{c}\text { Liczebność } \\
\text { respondentów }\end{array}$ & Procent & $\begin{array}{c}\text { Procent ważnych } \\
\text { odpowiedzi }\end{array}$ \\
\hline Tak & 246 & 42,9 & 43,5 \\
\hline Nie & 320 & 55,8 & 56,5 \\
\hline Ważne odpowiedzi & 566 & 98,8 & 100,0 \\
\hline Brak danych & 7 & 1,2 & \\
\hline Ogółem & 573 & 100,0 & \\
\hline
\end{tabular}

Źródło: opracowanie własne.

Tabela 23. Podmiot odpowiedzialny za rozwiązywanie problemów wsi/gminy

\begin{tabular}{|l|c|c|c|}
\hline \multicolumn{1}{|c|}{$\begin{array}{c}\text { Problemy wsi/gminy winni } \\
\text { przede wszystkim rozwiązywać: }\end{array}$} & $\begin{array}{c}\text { Liczebność } \\
\text { respondentów }\end{array}$ & Procent & $\begin{array}{c}\text { Procent ważnych } \\
\text { odpowiedzi }\end{array}$ \\
\hline Sami mieszkańcy & 34 & 5,9 & 6,1 \\
\hline Ludzie tacy, jak respondent & 9 & 1,6 & 1,6 \\
\hline Mieszkańcy przy pomocy władz lokalnych & 134 & 23,4 & 24,1 \\
\hline Władze lokalne przy pomocy mieszkańców & 198 & 34,6 & 35,5 \\
\hline $\begin{array}{l}\text { Władze przy pomocy mieszkańców i osób } \\
\text { takich, jak respondent }\end{array}$ & 136 & 23,7 & 24,4 \\
\hline Same władze lokalne & 46 & 8,0 & 8,3 \\
\hline Ogółem & 557 & 97,2 & 100,0 \\
\hline
\end{tabular}

Źródło: opracowanie własne.

Zazwyczaj padały dość ogólnikowe odpowiedzi typu: „wprowadziłbym bardziej kolegialny sposób podejmowania decyzji, liczyłbym się bardziej z opiniami mieszkańców itp." ${ }^{14}$ Wyobrażenie badanych członków LGD na temat najbardziej

${ }^{14}$ Biorąc pod uwagę podstawowe zmienne społeczno-demograficzne, należy stwierdzić, że zmienne te, poza zmienną dotyczącą kategorii zawodowej, nie różnicują w istotny sposób (mierzony tylko częstością wskazań) tych przekonań. Można było jedynie stwierdzić, iż przekonanie o potrzebie wprowadzenia zmian w sposobie funkcjonowania władzy lokalnej najczęściej deklarowały: osoby najstarsze, powyżej 65 . roku życia (45,9\%); najrzadziej osoby w wieku 35-44 lata 
pożądanego modelu funkcjonowania społeczności lokalnych i władzy lokalnej stojących przed koniecznością rozwiązania pojawiających się problemów bliskie jest idei społeczeństwa obywatelskiego [por. tabela 23].

Ponad jedna czwarta badanych $(34,6 \%)$ jest bowiem zdania, że problemy wsi/gminy powinny rozwiązywać przede wszystkim władze gminy we współpracy z mieszkańcami, prawie jedna czwarta $(23,7 \%)$, że władze lokalne przy pomocy mieszkańców i osób takich, jak respondent oraz prawie jedna czwarta $(23,4 \%)$ - że mieszkańcy przy pomocy władz lokalnych. Warto zauważyć, że wskazania na to, iż od rozwiązania problemów są tylko władze lokalne $(8,0 \%)$ są bardzo niskie, podobnie jak wskazania na samych mieszkańców $(5,9 \%)$ czy też na ludzi takich, jak respondent $(1,6 \%)^{15}$.

(42,0\%); osoby pracujące częściej (45,1\%) niż niepracujące (36,7\%). Potrzebę wprowadzenia zmian w sposobie funkcjonowania władzy lokalnej deklarowali najczęściej specjaliści (62,2\%) i właściciele gospodarstw rolnych (59,3\%); najrzadziej pracownicy fizyczni $(25,0 \%)$ [zob. załącznik 7 , tabela $7.9 \mathrm{w}$ aneksie].

15 Kobiety zdecydowanie częściej (44,8\%) niż mężczyźni (29,2\%) mówią o współpracy władzy lokalnej z mieszkańcami i rzadziej (20,4\%) niż mężczyźni (27,0\%), że władze lokalne zwracają się o pomoc mieszkańców i osób takich, jak respondent. Biorąc pod uwagę wiek, można stwierdzić, że nie występują tutaj jakieś istotne prawidłowości. Tym niemniej najczęściej za stwierdzeniem, że problemy wsi/gminy powinny rozwiązywać przede wszystkim władze gminy we współpracy z mieszkańcami opowiadały się osoby najstarsze, w wieku powyżej 65 lat (44,4\% wskazań wśród nich) oraz w wieku 35-44 lata (41,1\%); najczęściej za stwierdzeniem, że problemy wsi/gminy powinny rozwiązywać władze lokalne przy pomocy mieszkańców i osób takich, jak respondent opowiadały się również osoby najstarsze $(38,9 \%)$, a za stwierdzeniem, że przede wszystkim mieszkańcy przy pomocy władz lokalnych - osoby w wieku 55-64 (28,8\%) i w wieku 35-44 (28,6\%). Dość różnicująca okazała się zmienna dotycząca wykształcenia, zwłaszcza jeśli chodzi o wykształcenie poniżej średniego. Prawie jedna trzecia osób $(31,0 \%)$ o takim wykształceniu wskazywała na to, że od rozwiązywania problemów są tylko władze lokalne (wobec $2,7 \%$ wskazań pochodzących od osób z wykształceniem wyższym). Z kolei osoby z wykształceniem wyższym zdecydowanie częściej wskazywały na to, że problemy wsi/gminy winny być rozwiązywane przez władze lokalne przy pomocy mieszkańców i osób takich, jak respondent (28,0\% wskazań wobec 12,7\% wśród osób z wykształceniem niższym niż średnie [załącznik 7, tabela $7.10 \mathrm{w}$ aneksie]). Opinie badanych są też zróżnicowane w zależności od przynależności do niektórych kategorii zawodowych. Ponad $40,0 \%(42,0 \%)$ pracowników umysłowych i tylko $22,2 \%$ pracowników fizycznych jest za tym, by problemy wsi/gminy rozwiązywała przede wszystkim władza gminy we współpracy z mieszkańcami; $37,0 \%$, poza tym, jest zdania, że problemy ich wsi/gminy winna rozwiązywać sama gmina. Z kolei właściciele firm (aż 33,3\%) są za tym, aby te problemy rozwiązywali sami mieszkańcy przy pomocy władz lokalnych [załącznik 7 , tabela $7.11 \mathrm{w}$ aneksie]. Uwzględniając płeć badanych można stwierdzić, że kobiety $(55,2 \%)$ werbalizują zdecydowanie niższy poziom przekonania o możliwości rozwiązywania problemów środowiska niż mężczyźni (74,4\%); zdecydowanie częściej (40,0\%) niż mężczyźni $(23,5 \%)$ wskazują również na to, że wpływ ten zależy od tego, czego sprawa dotyczy. Osoby najstarsze (powyżej 65. roku życia) oraz najmłodsze (do 32. roku życia) najczęściej deklarują (odpowiednio: $11,1 \%$ i 10,4\%), że raczej nie mają wpływu na rozwiązywanie problemów środowiska. W odniesieniu do pozostałych kategorii wiekowych żadnych istotnych tendencji nie stwierdzono [zob. załącznik 7, tabela $7.12 \mathrm{w}$ aneksie]. Uwzględniając zmienną wykształcenia możemy 
Jak zatem wygląda samoocena wpływu członków LGD na rozwiązywanie niektórych problemów własnego środowiska, na to, że sytuacja może zmienić się na lepsze oraz samoocena wpływu na decyzje władz lokalnych? Z analizy wynika [por. tabela 24], że dwie trzecie badanych członków LGD (66,0\% wskazań) żywi przekonanie, że działania ich oraz osób takich jak oni mogą doprowadzić do rozwiązywania problemów występujących w miejscu zamieszkania czy gminie. Jednocześnie prawie jedna trzecia badanych osób $(30,7 \%)$ zastrzegła, że ten ich wpływ na rozwiązywanie problemów zależy od tego, czego ten problem dotyczy; tym samym część członków LGD miała świadomość, że nie wszystkie problemy da się rozwiązać choćby bez udziału władzy lokalnej ${ }^{16}$.

Tabela 24. Ocena własnego wpływu na sytuację w miejscowości/gminie według wykształcenia

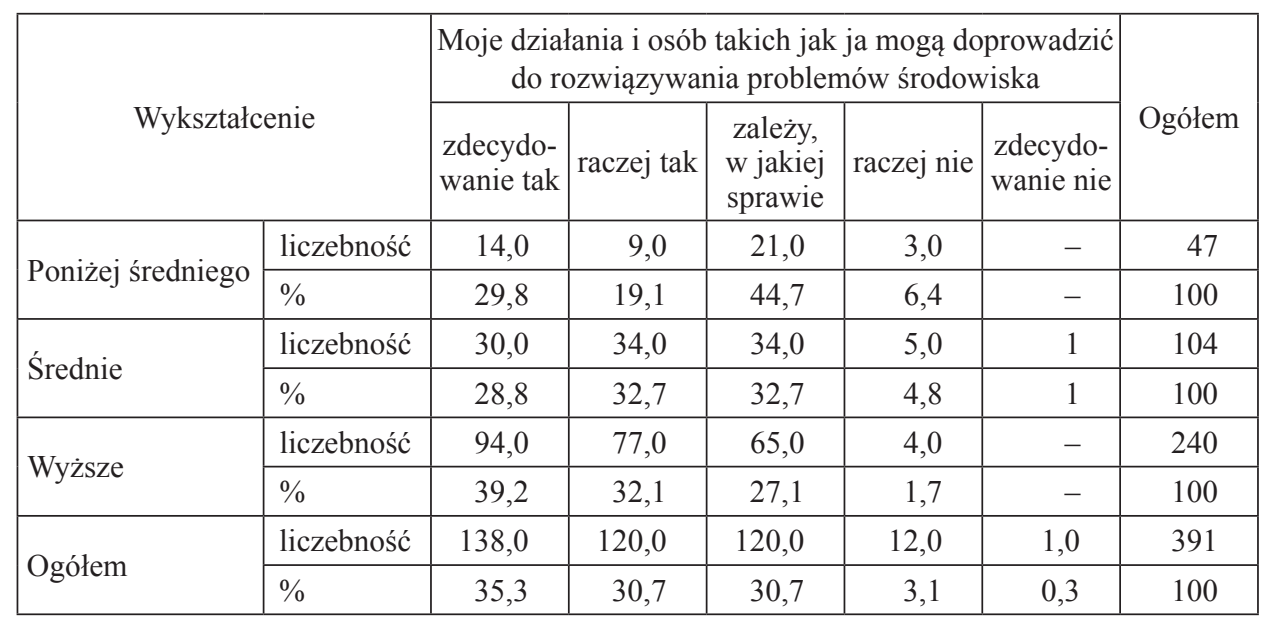

Źródło: opracowanie własne.

powiedzieć, że im wyższy poziom wykształcenia, tym częściej badani deklarują przekonanie o tym, że mają zdecydowanie tak lub raczej tak wpływ na rozwiązywanie problemów swojego środowiska. Osoby z wykształceniem niższym niż średnie częściej też stwierdzają, że wpływ ten zależy od tego, czego problem dotyczy (44,7\% wskazań wobec $27,1 \%$ wskazań od osób z wyższym wykształceniem) i częściej też deklarują, że raczej nie mają wpływu na rozwiązywanie występujących problemów. [zob. załącznik 7, tabela $7.13 \mathrm{w}$ aneksie].

${ }^{16}$ Fakt bycia zatrudnionym (niezatrudnionym) nie różnicuje opinii w tej kwestii badanych; osoby niepracujące jedynie częściej deklarują, że raczej nie mają wpływu na rozwiązywanie problemów swojego środowiska ( $8,2 \%$ wobec $2,1 \%$ dla pracujących). Jeśli zaś uwzględnimy przynależność członków LGD do poszczególnych kategorii zawodowych (zob. tabela 88), to możemy stwierdzić przede wszystkim, że najwyższe poczucie wpływu na rozwiązywanie problemów środowiska ma kadra kierownicza (82,9\% wskazań na „zdecydowanie tak” i „raczej tak”) i specjaliści (78,0\%); najniższe właściciele gospodarstw rolnych (44,0\%) i pracownicy fizyczni (47,6\%). Pracownicy fizyczni relatywnie najczęściej wskazują na to (4,8\% wskazań), że zdecydowanie nie mają żadnego wpływu [zob. załącznik 7, tabela $7.14 \mathrm{w}$ aneksie]. 
Członkowie LGD proszeni byli nie tylko o ocenę swojego wpływu na rozwiązywanie niektórych problemów własnego środowiska, lecz także wpływu osób takich jak oni na decyzje władz lokalnych dotyczące tego, co dzieje się w ich miejscowości i/lub gminie. Z wcześniejszych analiz wynika, że ponad jedna czwarta badanych $(34,6 \%)$ była zdania, że problemy wsi/gminy powinny rozwiązywać przede wszystkim władze gminy we współpracy z mieszkańcami, a prawie jedna czwarta $(23,7 \%)$ - że władze lokalne przy pomocy mieszkańców i osób takich, jak respondent.

Tabela 25. Ocena wpływu respondenta na decyzje władz lokalnych

\begin{tabular}{|l|c|c|c|}
\hline \multicolumn{1}{|c|}{ Poczucie wpływu } & $\begin{array}{c}\text { Liczebność } \\
\text { respondentów }\end{array}$ & $\begin{array}{c}\text { Procent ważnych } \\
\text { odpowiedzi }\end{array}$ & $\begin{array}{c}\text { Procent } \\
\text { skumulowany }\end{array}$ \\
\hline Bardzo duży wpływ & 62 & 15,6 & 15,6 \\
\hline Raczej duży wpływ & 113 & 28,4 & 44,0 \\
\hline Przeciętny wpływ & 169 & 42,5 & 86,4 \\
\hline Raczej mały wpływ & 44 & 11,1 & 97,5 \\
\hline Brak wpływu & 10 & 2,5 & 100,0 \\
\hline Ogółem & 398 & 100,0 & - \\
\hline
\end{tabular}

Źródło: opracowanie własne.

Z analizy wynika, że 44,0\% członków LGD miało poczucie bardzo dużego i raczej dużego wpływu na działania władz lokalnych; nieco mniej, bo $42,5 \%$, deklarowało wpływ przeciętny, $11,1 \%$ raczej miało wpływ, a tylko $2,5 \%$ cechował brak wpływu. Można więc stwierdzić, że członkowie LGD dostrzegają swą pozytywną rolę w społecznościach lokalnych, zwłaszcza jeśli chodzi o wywieranie wpływu na decyzje władz samorządowych [por. tabela 25$]^{17}$.

${ }^{17}$ Interesujące jest zatem przeanalizowanie tego zagadnienia przy uwzględnieniu podstawowych zmiennych społeczno-demograficznych. Analiza pokazała, że kobiety - członkinie LGD mają generalnie niższe poczucie wpływu na decyzje władz lokalnych niż mężczyźni. Ponad połowa spośród nich stwierdza, że ten ich wpływ jest przeciętny $(52,4 \%$ - tak sądzi tylko niewiele ponad jedna trzecia mężczyzn - 35,1\%), a 17,9\%, że jest to raczej wpływ niewielki bądź żaden (wobec $10,1 \%$ dla mężczyzn) [zob. załącznik 7 , tabela $7.15 \mathrm{w}$ aneksie]. Jeśli chodzi o zmienną wieku, to nie stwierdzono tutaj jakichś wyraźnych tendencji na poziomie rozkładu częstości wskazań poza jedną, dotyczącą osób najstarszych, po 65. roku życia wśród których aż 58,3\% ma poczucie bardzo dużego i raczej dużego wpływu na władzę lokalną. Jeśli chodzi o zmienną wykształcenia, to występuje tutaj dość typowa tendencja; im wyższy poziom wykształcenie członków LGD, tym częściej deklarują swój bardzo duży i duży wpływ na decyzje władz lokalnych; odpowiednio: 30,0\%, 36,2\% i 47,\% wskazań [zob. załącznik 7, tabela $7.16 \mathrm{w}$ aneksie]. Natomiast, kiedy uwzględnimy zmienną dotyczącą przynależności do kategorii zawodowych, to okazuje się, że relatywnie największy odsetek osób przekonanych o tym, że ma wpływ na decyzje władzy lokalnej znajduje się wśród kadry kie- 
Przedstawione $\mathrm{w}$ niniejszym fragmencie opracowania wyniki pokazują, że aktywność polityczna badanych wyróżnia ich na tle ogólnej aktywności Polaków, zwłaszcza, jeśli uwzględnimy fakt, że analiza dotyczyła środowiska wiejskiego. Respondenci wykazywali ponadprzeciętne zainteresowanie polityką, czego przejawem było m.in. uczestnictwo w różnego rodzaju wyborach oraz partycypowanie w przygotowywaniu kampanii wyborczych partii lub kandydatów. Ponad połowa badanych rozważała kandydowanie w wyborach samorządowych, a 44\% ich ogółu chciała coś zmienić w funkcjonowaniu władzy lokalnej.

Organizacje, do których przynależą - lokalne grupy działania - zrzeszają więc osoby nie tylko dysponujące wysokim poziomem kapitału ludzkiego, lecz także zainteresowane aktywnym uczestnictwem w życiu publicznym. Część z tych osób już dziś ogrywa rolę wójtów, burmistrzów, radnych, sołtysów, część $\mathrm{z}$ nich do tych ról dopiero aspiruje. Jest to znaczące w kontekście struktury lokalnych grup działania, a zwłaszcza relacji między ich członkami reprezentującymi różne sektory. Zasada partnerstwa (jedna z zasad przyświecających podejściu LEADER) zakłada, że te osoby będą ze sobą współpracowały na rzecz rozwoju partnerstwa. Na jakość tej współpracy niewątpliwie wpływają postawy badanych dotyczące ich udziału w sferze publicznej, a zwłaszcza krytyczny stosunek do władzy lokalnej (której przedstawiciele są członkami LGD) i gotowość do podjęcia starań o zmianę lokalnego, politycznego status quo. Jak zostanie wykazane w dalszej części, badani są aktywni w sferze politycznej, ale również społecznej. Sieć kontaktów wytworzonych dzięki tej działalności stanowi ważny element kapitału społecznego, jakim dysponują i który w różny sposób mogą wykorzystać. Zastanawiające jest, w jakim stopniu posiadane zasoby pomagają im funkcjonować w tych organizacjach.

rowniczej (62,6\% wskazań), najmniejszy zaś wśród właścicieli gospodarstw rolnych (29,1\% wskazań), wśród których znajduje się też największy odsetek osób deklarujących całkowity brak wpływu na decyzje władz lokalnych $(8,3 \%)$ [zob. załącznik 7 , tabela $7.17 \mathrm{w}$ aneksie]. 
ROZDZIAŁ III

\section{STRUKTURA I POZIOM KAPITAŁU SPOLECZNEGO LOKALNYCH GRUP DZIAŁANIA}

\subsection{Uwagi wstępne}

Zawarta $\mathrm{w}$ niniejszym rozdziale prezentacja danych dotyczących struktury kapitału społecznego lokalnych grup działania służy realizacji dwóch podstawowych celów. Pierwszym z nich jest wyczerpująca charakterystyka struktury kapitału społecznego badanych LGD, uwzględniająca jego różne aspekty (w szczególności zjawiska wchodzące w skład wyróżnionych wcześniej teoretycznych komponentów, tj. komponentu zaufania, komponentu norm i wartości oraz komponentu sieci). Cel drugi stanowi wskazanie powiązań (lub ich braku) pomiędzy opisanymi elementami struktury kapitału społecznego oraz oszacowanie poziomu każdego z nich. Ponadto, biorąc pod uwagę fakt, iż wśród głównych motywów badania znalazł się zamiar porównania poziomu kapitału społecznego lokalnych grup działania funkcjonujących w województwach o najmniejszej i największej sieci tego typu organizacji, a także weryfikacja hipotez dotyczących najważniejszych uwarunkowań zróżnicowania zasobów tegoż kapitału, w rozdziale podjęto się także oszacowania poziomu kapitału społecznego lokalnych grup działania jako pewnej całości (stanowiącej, zgodnie z przyjętą podstawą teoretyczną, sumę wyróżnionych komponentów składowych).

Dla większej przejrzystości prowadzonych analiz, po przeprowadzeniu charakterystyk opisowych wymienionych komponentów kapitału społecznego, zdecydowano się na skonstruowanie indeksów wyrażających poziom każdego z nich w postaci konkretnej wartości liczbowej. Ze względu na chęć stworzenia zmiennych syntetycznych wewnętrznie jednorodnych (odnoszących się do tego samego wymiaru badanego zjawiska), dobrze i w spójny sposób obrazujących poszczególne komponenty, do indeksów wyrażających składowe kapitału społecznego włączono mniejszą liczbę zmiennych niż wykorzystano w samej charakterystyce. Przeprowadzone analizy wstępne wskazały bowiem na brak powiązań między niektórymi zmiennymi (pierwotnie przyjmowanymi jako wskaźniki danego 
komponentu) a innymi zmiennymi z tego zbioru, a także na znaczące, z punktu widzenia prowadzonych analiz, braki danych ${ }^{1}$ dotyczące niektórych zmiennych cząstkowych. W konsekwencji za empiryczne wskaźniki kapitału społecznego, stanowiące podstawę konstrukcji jego miary syntetycznej, przyjęto zmienne stosunkowo najsilniej ze sobą skorelowane ${ }^{2} \mathrm{w}$ ramach każdego $\mathrm{z}$ komponentów i jednocześnie takie, w przypadku których uzyskano dane najbardziej kompletne.

Wszystkie indeksy wyrażające wartości poszczególnych (trzech) składowych każdego z wyróżnionych komponentów poddano transformacji. W jej wyniku indeks każdego komponentu sprowadzono do postaci trzypunktowej, gdzie wartość 0 oznaczała brak zaufania (akceptacji, uczestnictwa), zaś wartość 2 - duże zaufanie do większości kategorii nim objętych (wysoki poziom akceptacji większości norm, wysoki poziom uczestnictwa w większości wyróżnionych sieci). Syntetyczną wartość każdego komponentu jako całości uzyskano poprzez zsumowanie wartości poszczególnych składowych (uzyskując tym samym siedmiopunktowe indeksy zaufania, norm i wartości oraz sieci, obejmujące potencjalnie wartości od 0 do 6 ).

Sposoby przekodowania i agregacji zmiennych prowadzące do uzyskania rezultatów w formie wskaźników syntetycznych oraz otrzymane wartości tychże wskaźników zaprezentowano poniżej ${ }^{3}$, poprzedzając je zestawieniami szczegółowych rozkładów uzyskanych wyników cząstkowych (w postaci odpowiedzi na zadane respondentom pytania wskaźnikowe), ich charakterystyką i interpretacją.

\subsection{Charakterystyka komponentów kapitału społecznego badanych LGD}

Zgodnie z koncepcją Roberta D. Putnama, stanowiącą główną podstawę teoretyczną, kapitał społeczny jest układem trzech wzajemnie warunkujących się elementów składowych: zaufania i, opartych na nim, sieci powiązań między członkami społeczeństwa oraz norm wyznaczających ich postępowanie we wzajemnych relacjach (por. rozdział I).

Charakterystyki tzw. komponentu zaufania kapitału społecznego dokonano na podstawie analizy zmiennych zaufania sfery prywatnej oraz zmiennych zaufania sfery publicznej. Do pierwszych zaliczono: 1) zaufanie respondentów do rodziny, sąsiadów i współpracowników, a więc ich zaufanie do osób znanych,

${ }^{1}$ Przyczyny braków danych opisano szczegółowo w rozdziale 1.

${ }^{2}$ Mając pełną świadomość, że stwierdzone zależności (o co najwyżej średniej sile związku) ograniczają się wyłącznie do zbadanej zbiorowości, gdyż zrealizowany sposób doboru próby nie pozwala na wnioskowanie o ich istnieniu w populacji generalnej.

${ }^{3}$ Zastosowany schemat transformacji zaprezentowano szczegółowo na przykładzie miernika zaufania do osób znanych. 
2) zaufanie zgeneralizowane, tj. zaufanie badanych do osób obcych spotykanych w różnych sytuacjach życiowych oraz ich przekonanie o tym, iż większości ludzi można ufać. W zakresie zmiennych zaufania sfery publicznej uwagę skoncentrowano na deklaracjach respondentów dotyczących obdarzania zaufaniem tych instytucji, które mają szczególne znaczenie dla funkcjonowania lokalnych grup działania, tj. na ich zaufaniu do władz lokalnych gminy, organizacji pozarządowych z obszaru gminy oraz lokalnych przedsiębiorców.

Zmienne te mogą, ale nie muszą różnicować badaną zbiorowość. Mając na uwadze ostatnie wyniki badań nad zaufaniem społecznym Polaków (CBOS 2012) przypuszczano, iż respondenci będą cechować się wysokim poziomem zaufania do rodziny, nieco niższym, ale również wysokim poziomem zaufania do sąsiadów i współpracowników. Polacy ufają bowiem osobom z najbliższego otoczenia, w ogromnej większości rodzinie (97\%), znajomym (90\%), a także dalszym krewnym (89\%) i współpracownikom (84\%). Ponadto zamieszkiwanie na wsi i w małych miasteczkach (a więc na obszarach obejmowanych wsparciem lokalnych grup działania) sprzyja większej ufności do bezpośredniego otoczenia ${ }^{4}$ [Cybulska 2012: 6, 10].

A zatem, specyfika lokalnych grup działania decyduje o tym, iż (w wymiarze zaufania sfery prywatnej) interesujące będą, po pierwsze, deklaracje badanych dotyczące zaufania do współpracowników spoza i z LGD. Tu szczególnie znaczący będzie poziom ich zaufania do reprezentantów trzech sektorów (a zwłaszcza przedstawicieli sektora gospodarczego). Warto przypomnieć, że jego pozycja w LGD jest dość słaba - przedsiębiorcy rzadko angażują się w prace tych organizacji. Analizy prowadzone w województwie łódzkim wykazały, iż na tle przedstawicieli innych sektorów są oni obdarzani mniejszym zaufaniem [zob. Zajda 2011]. Ponadto w ostatnich badaniach CBOS odnotowano, iż Polacy są wyraźnie podzieleni w opiniach na temat partnerów biznesowych. Prawie tyle samo wyznaje zasadę, że zaufanie w interesach na ogół się opłaca (38\%) i opowiada się za zachowywaniem ostrożności oraz twierdzi, że zaufanie w tej dziedzinie na ogół źle się kończy (37\%) [Cybulska 2012: 2-3].

Po drugie, za interesujący uznano uogólniony poziom zaufania badanych (m.in. ich zaufanie do nieznajomych spotykanych w różnych sytuacjach życiowych). Tutaj należy zauważyć, że Polacy (a zwłaszcza mieszkańcy wsi) nadal są nieufni w stosunku do nich. Tylko niespełna jedna czwarta (23\%) wychodzi z założenia, że większości ludzi można ufać, blisko trzy czwarte zaś (74\%) wyznaje zasadę zachowywania daleko idącej ostrożności w stosunkach z innymi. Na pyta-

${ }^{4}$ Tego rodzaju otwartości wyraźnie sprzyja wyższy poziom wykształcenia, a także lepsze oceny własnych warunków materialnych [Cybulska 2012: 10].

${ }^{5}$ Wyższy poziom nieufności i ostrożności znacznie częściej cechuje również badanych najmłodszych, w wieku 18-24 lata, niż najstarszych, mających co najmniej 65 lat, a zwłaszcza osoby w okresie największej aktywności życiowej i zawodowej - od 35 do 44 roku życia. Spośród grup społeczno-zawodowych zdecydowanie najbardziej nieufni są robotnicy niewykwalifikowani oraz rolnicy, a także uczniowie i studenci [Cybulska 2012: 4]. 
nie o pozytywne nastawienie do nieznajomych, spotykanych w różnych sytuacjach życiowych, tylko jedna trzecia respondentów (34\%) odpowiada, że odnosi się do nich z ufnością [Cybulska 2012: 1,2,4].

W zakresie zaufania sfery publicznej interesujące były deklaracje badanych dotyczące zaufania, jakim obdarzają władze lokalne. Z jednej strony - jak wynika z ostatnich analiz CBOS - około trzech piątych Polaków ma zaufanie do władz lokalnych swojego miasta lub gminy (58\%) [Cybulska 2012: 12], z drugiej, historia realizacji podejścia LEADER w Polsce uwypukla problem municypalizacji LGD przez te instytucje. Zastanawiające jest, czy to zjawisko w jakiś sposób zaważy na postawach respondentów.

Na podstawie przeprowadzonych analiz można stwierdzić, że (podobnie jak miało to miejsce w większości badań nad kapitałem społecznym uwzględniającym wymiar zaufania do rozmaitych kręgów osób) także członkowie badanych lokalnych grup działania stosunkowo najwyższym poziomem zaufania obdarzali osoby najbliższe. Zgodnie z przypuszczeniami, prawie wszyscy ufali rodzinie (98\% ogółu). Na drugim miejscu znaleźli się współpracownicy z lokalnej grupy działania, którym ufało blisko $96 \%$ ankietowanych (ale, co warto podkreślić, tylko $57 \%$ ich ogółu ufało im w dużym stopniu).

Lokalne grupy działania funkcjonują od około 7-8 lat, to wystarczająco wiele, by ich członkowie (i partnerzy) mogli się dobrze poznać. Należy jednak pamiętać, że odgrywają oni w tych strukturach odmienne role - niektórzy są członkami zarządów oraz rad, czyli organów aktywnych w największym stopniu, takich, w których uczestnictwo wręcz zobowiązuje do kontaktów z pozostałymi członkami LGD. Dalej, niektórzy reprezentują sektor publiczny, który w świetle literatury przedmiotu kolonizuje działania lokalnych grup działania, inni sektor gospodarczy, który w społecznościach lokalnych często jest tym, który nieufnie odnosi się do poczynań władz lokalnych [por. Zajda 2012]. Interesujące było więc: 1) określenie poziomu zaufania badanych do współpracowników z LGD (na tle zaufania do tych osób, z którymi współpracują na co dzień), 2) ustalenie, czy istnieje związek między deklaracjami respondentów w zakresie zaufania do przedstawicieli trzech sektorów a ich przynależnością do: a) jednego z nich, b) struktury zarządu lub rady ${ }^{6}$.

Oczywisty wydaje się fakt, że wśród współpracowników z LGD najwyższym zaufaniem obdarzani byli zazwyczaj przedstawiciele sektora, z którego rekrutuje się respondent $-72 \%$ badanych darzyło ich dużym zaufaniem, a kolejne $21 \%$ zaufaniem umiarkowanym (podczas gdy przedstawicieli pozostałych dwóch sektorów dużym zaufaniem obdarzał co drugi z respondentów, 11\% deklarowało duże zaufanie tylko w stosunku do jednego $\mathrm{z}$ nich, a 30\% umiarkowane zaufanie do

\footnotetext{
${ }^{6}$ Ze względu na fakt, że badania nie były prowadzone w oparciu o próbę losową, nie mamy możliwości posługiwania się podczas interpretacji danych ani poziomem istotności statystycznej, ani określać (na podstawie różnych współczynników statystycznych) siły związku między zmiennymi. Możemy jedynie obserwować współzmienność poszczególnych cech populacji.
} 
obu). Zaufanie do przedstawicieli poszczególnych sektorów okazało się znacząco zróżnicowane [por. tabela 26].

Tabela 26. Zaufanie członków LGD do współpracowników z tej organizacji

\begin{tabular}{|l|c|r|c|}
\hline $\begin{array}{c}\text { Czy, ogólnie rzecz biorąc, ma Pan(i) zaufanie do } \\
\text { osób, które wchodzą w skład lokalnej grupy dzia- } \\
\text { łania, a reprezentują: }\end{array}$ & \multicolumn{2}{|c|}{ Wypowiedzi badanych [w \%], N = 573 } \\
\cline { 2 - 4 } & tak & nie & $\begin{array}{c}\text { trudno } \\
\text { powiedzieć }\end{array}$ \\
\hline Sektor publiczny & 65,1 & 12,9 & 21,9 \\
\hline Sektor społeczny & 70,8 & 7,6 & 21,6 \\
\hline Sektor gospodarczy & 56,1 & 14,6 & 29,3 \\
\hline
\end{tabular}

Źródło: opracowanie własne.

Stosunkowo najniższym poziomem zaufania (w analizowanych organizacjach) byli obdarzani przedstawiciele sektora gospodarczego. Odnotowane $\mathrm{w}$ literaturze problemy związane z jego deficytem znalazły potwierdzenie w przeprowadzonych badaniach. Członkom LGD reprezentującym sektor gospodarczy ufała tylko nieco ponad połowa współpracowników. Nieufnie nastawieni do nich byli przede wszystkim reprezentanci sektora publicznego (ponad $16 \%$ tych badanych stwierdziło, iż nie darzy ich zaufaniem). W największym stopniu ufali im reprezentanci sektora gospodarczego (63\% z nich stwierdziło, że darzy ich zaufaniem). Stosując sformułowaną przez R. Mertona zasadę św. Mateusza: „bogaci będą jeszcze bogatsi, a ubodzy jeszcze biedniejsi" [1996: 318-336, za: Sztompka 2007: 246], można przypuszczać, iż niższy poziom zaufania, jakim są obdarzani członkowie LGD reprezentujący sektor gospodarczy może ograniczać poszerzanie składu struktury o jego kolejnych reprezentantów [Zajda 2011a: 126].

Nieco większy odsetek respondentów - 65\% ogółu (w porównaniu do tych, którzy zadeklarowali zaufanie w stosunku do przedstawicieli sektora gospodarczego) ufał członkom LGD reprezentującym sektor publiczny. W największym stopniu deklaracje zaufania złożyli jego przedstawiciele (około $75 \%$ z nich). Ufało im także blisko $63 \%$ przedstawicieli sektora gospodarczego. Zastanawiające wydają się natomiast powody, dla których dość niski poziom zaufania w stosunku do nich wykazali reprezentanci sektora społecznego (tylko około $62,2 \% \mathrm{z}$ nich zadeklarowało, że je posiada). Być może jest to związane z nadmiernym wpływem, jaki przedstawiciele (najczęściej władzy lokalnej) wywierają na funkcjonowanie LGD.

$\mathrm{W}$ lokalnych grupach działania największym zaufaniem cieszą się przedstawiciele sektora społecznego. Ufało im około $72 \%$ respondentów z sektora publicznego, $63 \%$ z sektora gospodarczego oraz $75 \%$ z sektora społecznego. Choć poziom zaufania, jakim są obdarzani, jest wysoki, to znaczący jest odsetek respondentów z poszczególnych sektorów, którzy deklarują brak zaufania w stosunku do tej kategorii współpracowników (lub nie są pewni swojej opinii w tej sprawie), wynosi on 
od około $25 \%$ do $37 \%$. Być może jest to związane z ukrywaniem się pod szyldem NGO reprezentantów sektora publicznego, których status nie wzbudza zaufania.

Członkostwo w zarządzie nie różnicowało wypowiedzi badanych w zakresie zaufania do przedstawicieli sektora publicznego i społecznego w LGD (ufało im odpowiednio $76 \%$ oraz $77 \%$ badanych). Członkowie tego organu z większą nieufnością odnosili się do reprezentantów sektora gospodarczego (ufało im 68\% z nich). Podobnie członkowie rady (w takim samym stopniu) obdarzali zaufaniem przedstawicieli sektora publicznego i społecznego (taką deklarację złożyło 71\% ich ogółu). Reprezentantom sektora gospodarczego ufali oni w mniejszym zakresie (ufność w stosunku do nich zadeklarowało 62\% respondentów z tego organu). Oba wyniki zdają się potwierdzać specyficzną sytuację przedsiębiorców w strukturze LGD. Zarazem świadczą albo o niewielkim natężeniu zjawiska municypalizacji, albo o jego legitymizacji, u której podstaw leży przekonanie, iż jest ona korzystna, a może nawet pożądana $\mathrm{w}$ tak wysoce sprofesjonalizowanych organizacjach.

Zdecydowana większość respondentów ( $90 \%$ ogółu) obdarzała zaufaniem także współpracowników spoza LGD (w przypadku 70\% badanych to zaufanie można określić mianem dużego). Nieco mniejszy odsetek respondentów (79\% ogółu) zadeklarował zaufanie do sąsiadów (w przypadku blisko 58\% badanych jego poziom można określić mianem dużego). W tabeli 27 . zestawiono rozkłady odpowiedzi na wszystkie pytania wskaźnikowe dotyczące zaufania do osób znanych? ${ }^{7}$.

Tabela 27. Rozkłady odpowiedzi na pytania wskaźnikowe - poziom zaufania do osób znanych

\begin{tabular}{|l|c|c|c|c|c|c|}
\hline \multirow{2}{*}{ Zaufanie do osób znanych } & \multicolumn{2}{|c|}{ Duże } & \multicolumn{2}{c|}{ Umiarkowane } & \multicolumn{2}{c|}{ Brak } \\
\cline { 2 - 8 } & liczba & odsetek & liczba & odsetek & liczba & odsetek \\
\hline Zaufanie do sąsiadów (N = 568) & 329 & 57,9 & 120 & 21,1 & 119 & 21 \\
\hline $\begin{array}{l}\text { Zaufanie do współpracowników } \\
\text { spoza LGD (N = 570) }\end{array}$ & 401 & 70,4 & 109 & 19,1 & 60 & 10,5 \\
\hline $\begin{array}{l}\text { Zaufanie do współpracowników z LGD } \\
(\mathrm{N}=548)\end{array}$ & 312 & 56,9 & 212 & 38,7 & 24 & 4,4 \\
\hline
\end{tabular}

Źródło: opracowanie własne.

${ }^{7} \mathrm{~W}$ pytaniach wskaźnikowych sformułowanych w postaci: Czy, ogólnie rzecz biorac, ma Pan(i) zaufanie do...? respondenci mieli do wyboru odpowiedzi „tak”, „trudno powiedzieć”, „nie”, które interpretowano odpowiednio jako wysoki poziom zaufania, umiarkowany poziom zaufania oraz jego brak, przypisując im wartości liczbowe od 2 do 0 . Odpowiedzi na pytania wskaźnikowe zsumowano, zaś uzyskaną w ten sposób wartość poddano transformacji, sprowadzając wartość indeksu zaufania do osób znanych do postaci trzypunktowej 0-2, gdzie 0 oznaczało całkowity brak zaufania do co najmniej dwóch spośród uwzględnionych kategorii osób znanych i co najwyżej umiarkowane zaufanie do trzeciej, 2 oznaczała duże zaufanie co najmniej do dwóch spośród wyróżnionych kategorii osób i co najmniej umiarkowane zaufanie do trzeciej, zaś wartość 1 obejmowała sytuacje pośrednie. Indeksy wyrażające syntetyczne wartości pozostałych elementów składowych komponentów kapitału społecznego (wyróżnionych na potrzeby badania) potraktowano analogicznie. 
Próbując wyjaśnić różnice między zaufaniem badanych do współpracowników spoza LGD a ich zaufaniem do sąsiadów można wskazać, że w środowisku pracy częściej spotykamy osoby cechujące się podobnym poziomem wykształcenia, zakresem wykonywanych obowiązków. Praca w tym samym urzędzie, referacie, instytucji może pozytywnie oddziaływać na zaufanie, jakim obdarzamy innych [por. Sztompka 2007: 165], tym bardziej, iż towarzyszy jej względne oddzielenie sfery życia prywatnego od publicznego. Na wsi roli sąsiada przypisuje się cechy pozytywne (pomoc sąsiedzka), ale też negatywne (nadmierne zainteresowanie życiem prywatnym osób mieszkających obok, na tej samej ulicy, w tej samej miejscowości). Sąsiedzi mogą znacząco się od nas różnić (statusem zawodowym, materialnym). Jednocześnie są blisko prywatnej sfery życia, stając się (świadomie czy nieświadomie) jej obserwatorami i krytykami. Innymi słowy, być może zmienną wyjaśniającą niższy poziom zaufania badanych w stosunku do sąsiadów są różnice między nimi w statusie społecznym oraz w definiowaniu granic życia prywatnego.

Podsumowując rezultaty dotyczące zaufania respondentów do osób, z którymi spotykają się w rozmaitych codziennych sytuacjach, należy stwierdzić, że aż $60 \%$ spośród badanych członków LGD ufa wszystkim trzem wymienionym kategoriom osób znanych ${ }^{8}$ (z czego co najmniej dwie obdarza dużym zaufaniem), a tylko $6 \%$ ankietowanych darzy co najwyżej umiarkowanym zaufaniem tylko jedną z nich (najczęściej współpracowników z lokalnej grupy działania), nie ufając dwóm pozostałym [tabela 28].

Tabela 28. Składowe komponentu zaufania - zaufanie do osób znanych

\begin{tabular}{|c|c|c|c|c|c|c|}
\hline \multirow{3}{*}{$\begin{array}{l}\text { Zaufanie do osób znanych }\left(\mathrm{Z}_{1}\right) \\
\qquad \mathrm{N}=547\end{array}$} & \multicolumn{2}{|c|}{$\begin{array}{c}\mathrm{Z}_{1}=2 \\
\text { Duże zaufanie } \\
\text { do co najmniej dwu } \\
\text { kategorii }\end{array}$} & \multicolumn{2}{|c|}{$Z_{1}=1$} & \multicolumn{2}{|c|}{$\begin{array}{c}Z_{1}=0 \\
\text { Co najwyżej umiarko- } \\
\text { wane zaufanie } \\
\text { do jednej kategorii }\end{array}$} \\
\hline & liczba & odsetek & liczba & odsetek & liczba & odsetek \\
\hline & 328 & 60 & 186 & 34 & 33 & 6 \\
\hline
\end{tabular}

Źródło: opracowanie własne.

Średnia wartość syntetycznego wskaźnika zaufania do osób znanych (przyjmującego wartości z przedziału 0-2) wynosi 1,54.

Odnotowany w badaniu i zaprezentowany poziom zaufania sfery prywatnej badanych znacząco odbiegał od poziomu zaufania, jakim obdarzali oni osoby obce

${ }^{8}$ Deklarowane przez niemal wszystkich respondentów zaufanie do rodziny nie znalazło się w ramach prezentowanego poniżej zbiorczego wskaźnika zaufania do osób znanych ze względu na relatywnie słabe powiązanie z innymi składowymi. W jego ramach uwzględniono: zaufanie do sąsiadów oraz zaufanie do współpracowników z LGD i spoza LGD. 
spotykane w różnych sytuacjach życiowych. Odsetek tych, którzy zadeklarowali duże zaufanie do nieznajomych (spotykanych w różnych sytuacjach życiowych) wynosił zaledwie $19,8 \%$, aż 46,6\% respondentów zadeklarowało w stosunku do nich zaufanie umiarkowane (w kwestionariuszu zaznaczyło odpowiedź „trudno powiedzieć").

Można więc mówić o relatywnie niskim poziomie zaufania badanych w stosunku do nieznajomych. Zainteresowanie wzbudza rozbieżność pomiędzy tym wymiarem cechującego ich zaufania a ich opinią na temat tego, czy większości ludzi można ufać - około $67 \%$ z nich stwierdziło, że zgadza się z tym, iż można im ufać [tabela 29].

Tabela 29. Rozkłady odpowiedzi na pytania wskaźnikowe - poziom zaufania społecznego

\begin{tabular}{|l|r|r|r|r|r|r|}
\hline \multirow{2}{*}{ Zaufanie społeczne } & \multicolumn{2}{|c|}{ Duże } & \multicolumn{2}{c|}{ Umiarkowane } & \multicolumn{2}{c|}{ Brak } \\
\cline { 2 - 8 } & liczba & odsetek & liczba & odsetek & liczba & dsetek \\
\hline $\begin{array}{l}\text { Zaufanie do obcych spotyka- } \\
\text { nych w różnych sytuacjach } \\
\text { życiowych (N = 566) }\end{array}$ & 112 & 19,8 & 264 & 46,6 & 190 & 33,6 \\
\hline \multicolumn{2}{|c|}{ Tak } & \multicolumn{2}{|c|}{-} & - & \multicolumn{2}{|c|}{ Nie } \\
\hline $\begin{array}{l}\text { Przekonanie, że większości } \\
\text { ludzi można ufać (N = 546) }\end{array}$ & 367 & 67,2 & - & - & 179 & 32,8 \\
\hline
\end{tabular}

Źródło: opracowanie własne.

Być może wyjaśnieniem takiego stanu rzeczy jest konstruowana przez badanych definicja obcego, a konkretniej rozbieżność pomiędzy jej konotacją w przypadku dwóch pytań. W pierwszym („Czy, ogólnie rzecz biorąc, ma Pan(i) zaufanie do osób obcych spotykanych w różnych sytuacjach życiowych") respondenci (wyobrażając sobie spotkanie z obcym) mogą odczuwać większe poczucie zagrożenia. W drugim („Czy, ogólnie rzecz biorąc, uważa Pan(i), że: 1. Większości ludzi można zaufać, 2. Większości ludzi nie można zaufać") swoje przekonania odnoszą do niesprecyzowanego ogółu ludzi, których wcale w życiu codziennym nie muszą spotkać.

Syntetyzujący obie opisane zmienne wskaźnik uogólnionego zaufania społecznego cechuje się najniższą średnią wartością spośród składowych komponentu zaufania (1,02 w skali $0-2)$. Tylko niespełna 15\% ogółu badanych członków lokalnych grup działania uważało, że większości ludzi (włączając w to osoby obce, spotykane w różnych sytuacjach życiowych) można zaufać [por. tabela 30]. Wprawdzie tylko nieznacznie większy odsetek respondentów (niespełna 17\% ich ogółu) zadeklarował całkowity brak zaufania do przeważającej części swojego otoczenia społecznego, jednak zdecydowana większość (niemal 70\% ich ogółu), 
podzielając opinię o tym, że większości ludzi można zaufać, jednocześnie wyłączyła z tej większości osoby nieznajome.

Tabela 30. Składowe komponentu zaufania - zaufanie społeczne

\begin{tabular}{|c|c|c|c|c|c|c|}
\hline \multirow[t]{3}{*}{$\begin{array}{l}\text { Zaufanie społeczne }\left(Z_{2}\right) \\
\qquad N=541\end{array}$} & \multicolumn{2}{|c|}{$\begin{array}{c}\mathrm{Z}_{2}=2 \\
\text { Duże zaufanie do } \\
\text { większości ludzi } \\
\text { (w tym obcych) }\end{array}$} & \multicolumn{2}{|c|}{$\begin{array}{c}\mathrm{Z}_{2}=1 \\
\text { Zaufanie do więk- } \\
\text { szości ludzi (z wyłą- } \\
\text { czeniem obcych) }\end{array}$} & \multicolumn{2}{|c|}{$\begin{array}{l}\quad Z_{2}=0 \\
\text { Brak zaufania do } \\
\text { większości ludzi }\end{array}$} \\
\hline & liczba & odsetek & liczba & odsetek & liczba & odsetek \\
\hline & 79 & 14,6 & 373 & 68,9 & 89 & 16,5 \\
\hline
\end{tabular}

Źródło: opracowanie własne.

Tymczasem to właśnie ten typ zaufania (do osób nieznajomych spotykanych w rozmaitych sytuacjach życiowych) warunkuje skłonność do wchodzenia w bardziej zróżnicowane relacje społeczne i ułatwia dostęp do zróżnicowanych informacji oraz pozyskiwanie z nich rozmaitych korzyści, także ekonomicznych (budowanie zróżnicowanych typów zasobów kapitału społecznego). W sytuacji niedostatku zgeneralizowanego zaufania społecznego oraz wystarczająco efektywnych instytucji regulujących relacje społeczno-ekonomiczne skłonność do podejmowania nowych działań (zwłaszcza w sferze gospodarczej) maleje lub przyjmuje postać patologiczną [Growiec 2011].

Przeprowadzone badania wykazały niski (choć nieco wyższy w przypadku zaufania społecznego) poziom zaufania badanych do lokalnych instytucji i organizacji. Respondentów zapytano o ich zaufanie względem instytucji kluczowych dla funkcjonowania lokalnych grup działania, czyli władz lokalnych, organizacji pozarządowych działających na terenie gminy oraz lokalnych przedsiębiorców [tabela 31].

Tabela 31. Rozkłady odpowiedzi na pytania wskaźnikowe - poziom zaufania do instytucji lokalnych

\begin{tabular}{|l|c|c|c|r|r|r|}
\hline \multirow{2}{*}{$\begin{array}{c}\text { Zaufanie do instytucji } \\
\text { i organizacji lokalnych }\end{array}$} & \multicolumn{2}{|c|}{ Duże } & \multicolumn{2}{c|}{ Umiarkowane } & \multicolumn{2}{c|}{ Brak } \\
\cline { 2 - 7 } & liczba & odsetek & liczba & odsetek & liczba & odsetek \\
\hline $\begin{array}{l}\text { Zaufanie do władz lokalnych } \\
(\mathrm{N}=567)\end{array}$ & 254 & 44,8 & 170 & 30 & 143 & 25,2 \\
\hline $\begin{array}{l}\text { Zaufanie do organizacji } \\
\text { pozarządowych działających } \\
\text { na terenie gminy (N = 567) }\end{array}$ & 308 & 54,3 & 172 & 30,3 & 87 & 15,3 \\
\hline $\begin{array}{l}\text { Zaufanie do lokalnych przed- } \\
\text { siębiorców (N = 551) }\end{array}$ & 145 & 26,3 & 269 & 48,8 & 137 & 24,9 \\
\hline
\end{tabular}

Źródło: opracowanie własne. 
Władzom lokalnym bez zastrzeżeń ufało około 44,8\% respondentów (dla przypomnienia odsetek Polaków, którzy im ufają w ostatnich badaniach CBOS wyniósł 58\%). W największym stopniu darzyli ich zaufaniem badani z sektora publicznego (57\% z nich złożyło taką deklarację), w mniejszym (po około $40 \%$ wskazań) z sektora gospodarczego i społecznego. A zatem istnieje rozbieżność pomiędzy zaufaniem członków LGD do współpracowników z tego sektora a ich zaufaniem do władzy lokalnej (tym pierwszym ufają oni w większym stopniu). Poszukując wyjaśnień takiego stanu rzeczy można, po pierwsze, odwołać się do potencjalnego wpływu interakcji face to face na zmianę postaw badanych (figura władzy lokalnej może zostać zastąpiona wizerunkiem konkretnej osoby, podobnej do wielu znanych nam z sąsiedztwa). Po drugie, znacząca może być personifikacja kontaktów w LGD - wójt czy burmistrz występuje tu nie tylko w roli reprezentanta władzy lokalnej, lecz także jako konkretna osoba, mająca imię i nazwisko, odgrywająca rolę nie unikatową, lecz podobną do tych, jakie odgrywają inni, np. członka rady, zarządu. Po trzecie, rozbieżność między zaufaniem do współpracowników w LGD z sektora publicznego a zaufaniem do władzy lokalnej może wynikać ze specyfiki pracy w LGD. Z założenia jest ona non-profit (prowadzona nie dla zysku). W związku z tym badani mogą być przekonani, że konkretne osoby, które w nią się zaangażowały, nie mają złych intencji, nie zabiegają wyłącznie o realizację partykularnych interesów, a wręcz przeciwnie, działają na rzecz dobra publicznego, poświęcając swój czas wolny.

Zaskakująco niskie okazało się zaufanie respondentów do lokalnych organizacji pozarządowych. Wprawdzie zaufanie do nich zadeklarował największy odsetek badanych, bo aż 85\% spośród nich, ale w przypadku więcej niż co trzeciego (36\% respondentów z tej kategorii) to zaufanie można określić mianem umiarkowanego. Lokalnym organizacjom pozarządowym w dużym stopniu ufało $49 \%$ badanych z sektora publicznego, $49 \%$ z gospodarczego oraz $60 \%$ ze społecznego. W związku z powyższym można postawić hipotezę, że w wielu przypadkach ich przedstawiciele nie są postrzegani jako niezależni rzecznicy interesu publicznego, a same organizacje - jako podmioty uwikłane w różne relacje z władzą lokalną, o nie do końca jasno określonych celach działania.

Stosunkowo najniższy poziom (zgodnie z przypuszczeniami) osiągnęło zaufanie badanych do lokalnych przedsiębiorców. W dużym stopniu ufał im tylko co czwarty respondent, również co czwarty nie ufał im w ogóle. Połowa członków lokalnych grup działania zadeklarowała tylko umiarkowane zaufanie do przedstawicieli biznesu działających na obszarze partnerstwa. Co ciekawe, przedsiębiorcom w najmniejszym stopniu ufali inni przedsiębiorcy (przedstawiciele sektora gospodarczego w LGD) oraz członkowie NGO (w obu przypadkach pełne zaufanie do nich zadeklarowało po $24 \%$ badanych). Odsetek wskazań reprezentantów sektora publicznego był nieco wyższy - $31 \% \mathrm{w}$ dużym stopniu ufało przedsiębiorcom. Zdaje się, że wśród respondentów dominuje przekonanie o „machiawelicznym" nastawieniu przedsiębiorców do rzeczywistości społecznej, przejawiającym 
się w tym, iż jedynym wyznacznikiem ich działalności jest chęć osiągnięcia zysku, realizacji własnego interesu.

Konkludując ustalenia dotyczące zaufania wertykalnego, cechującego badanych, należy odnotować jego stosunkowo niski poziom (biorąc pod uwagę specyfikę funkcjonowania lokalnych grup działania oraz ich skład). Duże zaufanie do większości wyróżnionych typów instytucji lokalnych (zazwyczaj są to organizacje pozarządowe i władze lokalne) zadeklarował zaledwie co trzeci z badanych, podczas gdy nieco więcej niż co ósmy (blisko 12\% ogółu) obdarzał umiarkowanym zaufaniem co najwyżej jedną z kategorii uwzględnionych w ramach tego wymiaru. Instytucjami, do których stosunkowo największa grupa badanych w ogóle nie miała zaufania są władze lokalne i lokalni przedsiębiorcy (w obu przypadkach brak zaufania zadeklarował co czwarty respondent), zaś instytucjami wzbudzającymi co najmniej umiarkowane zaufanie wśród największego odsetka ankietowanych są organizacje pozarządowe (nie ufało im tylko 15\% respondentów). Średnia wartość syntetycznego wskaźnika zaufania do instytucji (osiągającego wartości z przedziału 0-2) wynosi w badanej grupie 1,21 [tabela 32].

Tabela 32. Składowe komponentu zaufania - zaufanie do instytucji i organizacji lokalnych

\begin{tabular}{|c|c|c|c|c|c|c|}
\hline \multirow{2}{*}{$\begin{array}{c}\text { Zaufanie do lokalnych } \\
\text { instytucji i organizacji } \\
\text { pozarządowych }\left(Z_{2}\right)\end{array}$} & \multicolumn{2}{|c|}{$Z_{3}=2$} & \multicolumn{2}{c|}{$Z_{3}=1$} & \multicolumn{2}{c|}{$Z_{3}=0$} \\
\cline { 2 - 8 } & liczba & odsetek & liczba & odsetek & liczba & odsetek \\
\cline { 2 - 8 }$N=548$ & 181 & 33 & 303 & 55,3 & 64 & 11,7 \\
\hline
\end{tabular}

Źródło: opracowanie własne.

Zaprezentowane charakterystyki zjawisk wchodzących w skład pierwszego z wyróżnionych komponentów kapitału społecznego pokazują jego wewnętrzną niejednorodność. O ile zaufanie do osób znanych, spotykanych w codziennych sytuacjach jest stosunkowo duże (jego syntetyczny wskaźnik uzyskuje średnią wartość 1,54 w skali 0-2), o tyle zaufanie do instytucji lokalnych (średnia wartość wskaźnika wyniosła 1,21 w skali 0-2) oraz szczególnie zaufanie do osób nieznajomych (średnia wartość wskaźnika wyniosła 1,02 w skali 0-2) pozostaje na poziomie stosunkowo niskim. W związku z tym także suma opisanych składowych, wyrażająca zbiorczą wartość komponentu zaufania, nie osiągnęła szczególnie wysokiego poziomu, jakiego spodziewano się w analizowanej zbiorowości. Wprawdzie całkowity brak zaufania do większości wyróżnionych kategorii osób (przy co najwyżej umiarkowanym zaufaniu do nie więcej niż dwóch spośród nich) charakteryzował niespełna $3 \%$ badanych, ale najwyższy poziom komponentu (obejmujący duże zaufanie do większości wyróżnionych kategorii i co najmniej umiarkowane zaufanie do pozostałych) cechował tylko co dziesiątego respondenta [por. wykres 1]. Średni poziom komponentu zaufania wyrażony w skali od 0 do 6 punktów (w badanej grupie) osiągnął poziom 3,79 punktu. 
Wykres 1. Poziom komponentu zaufania w badanych LGD

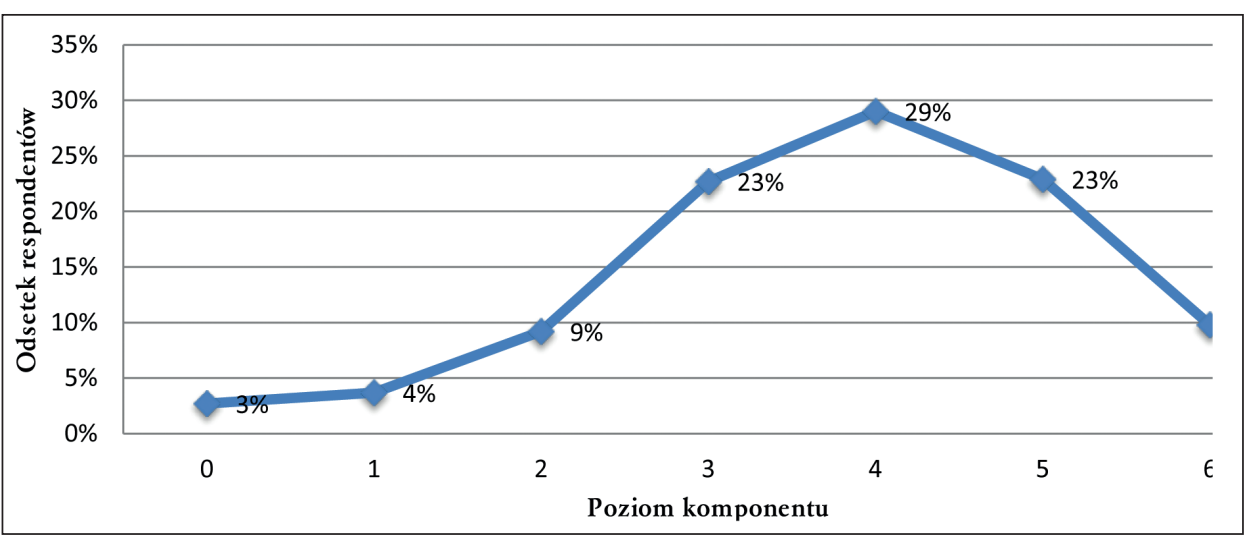

Źródło: opracowanie własne.

Drugim z wyróżnionych komponentów kapitału społecznego, którego poziom starano się określić w podjętych analizach, był komponent norm i wartości podzielanych przez członków lokalnych grup działania. Ten wymiar badano za pomocą kilku złożonych zmiennych. Pierwszą z nich był patriotyzm lokalny respondentów, w skład którego wchodziły zmienne cząstkowe, takie jak: ich więź z gminą zamieszkania, uczestnictwo w ostatnich wyborach samorządowych, gotowość ponoszenia wydatków na rzecz promowania lokalnej kultury ${ }^{9}$. Analizowano również normy i wartości społeczne, podzielane przez członków LGD, związane z podejściem LEADER. Zaliczono do nich przekonanie badanych o konieczności reprezentowania przez nich interesów mieszkańców partnerstwa oraz przekonanie, że taki sam motyw działalności w organizacji towarzyszy innym członkom LGD, obok przeświadczenia o konieczności nawiązania współpracy (na rzecz rozwoju gmin tworzących obszar partnerstwa) między członkami wszystkich sektorów ${ }^{10}$. Analizowano też społecznikostwo respondentów, rozumiane jako chęć kontynuacji działania na rzecz mieszkańców partnerstwa w strukturze LGD, gotowość do niesienia pomocy innym oraz poczucie podmiotowości respondentów (wyrażające się w deklarowanym przez nich poziomie kontroli nad własnym życiem ${ }^{11}$ ).

9 Do syntetycznego wskaźnika „patriotyzmu lokalnego” włączono dwie pierwsze zmienne. Ostatniej z nich nie uwzględniono ze względu na fakt, że odpowiedzi na pytanie dotyczące gotowości do ponoszenia wydatków na rzecz lokalnej kultury udzieliła znacząco mniejsza liczba badanych (niespełna $3 / 4$ ogółu).

${ }^{10}$ Ze względu na chęć zachowania jego wewnętrznej spójności syntetyczny wskaźnik zbudowano w oparciu o deklaracje dotyczące samego respondenta, pomijając jego przypuszczenia na temat motywów działania innych członków LGD.

${ }^{11}$ W skład syntetycznego wskaźnika nie włączono deklaracji dotyczących dalszego uczestnictwa w LGD, ponieważ w ramach tej zmiennej odnotowano stosunkowo dużą liczbę braków danych (odpowiedzi nie udzieliło 30\% ogółu respondentów). 
Badani okazali się lokalnymi patriotami. Prawie $87 \%$ z nich zadeklarowało, że gdyby miało niczym nieograniczoną możliwość wyboru miejsca zamieszkania, pozostałoby tu, gdzie mieszka. Aż trzy czwarte badanych, którzy udzielili odpowiedzi na pytanie o gotowość ofiarowania pieniędzy na rzecz wydarzeń promujących kulturę obszaru objętego działalnością lokalnej grupy działania zadeklarowało chęć finansowego wsparcia działań realizowanych w tym zakresie. Respondenci byli gotowi wspierać zespoły śpiewacze, taneczne, sztukę ludową oraz lokalne produkty. Niemal 9 na 10 ankietowanych uczestniczyło także w ostatnich wyborach samorządowych [tabela 33].

Tabela 33. Rozkłady odpowiedzi na pytania wskaźnikowe - patriotyzm lokalny

\begin{tabular}{|l|c|c|c|c|}
\hline \multirow{2}{*}{ Patriotyzm lokalny } & \multicolumn{2}{|c|}{ Tak } & \multicolumn{2}{c|}{ Nie } \\
\cline { 2 - 5 } & liczba & odsetek & liczba & odsetek \\
\hline Więź z gminą zamieszkania $(\mathrm{N}=569)$ & 494 & 86,8 & 75 & 13,2 \\
\hline $\begin{array}{l}\text { Uczestnictwo w ostatnich wyborach } \\
\text { samorządowych LGD }(\mathrm{N}=570)\end{array}$ & 504 & 88,4 & 66 & 11,6 \\
\hline
\end{tabular}

Źródło: opracowanie własne.

Warto podkreślić, że respondenci nie tylko brali udział w wyborach samorządowych, lecz także wielu z nich (58\% ogółu) partycypowało w przygotowaniu kampanii wyborczej, wykonywało jakieś prace na rzecz kandydata albo partii/komitetu wyborczego. Ponadto prawie $52 \%$ badanych zastanawiało się nad kandydowaniem na radnego, wójta czy burmistrza. Wśród motywacji towarzyszących podjęciu decyzji o udziale $\mathrm{w}$ wyborach lokalnych w tym charakterze przeważały te dotyczące chęci działania na rzecz interesów mieszkańców gminy.

Przedstawione rezultaty cząstkowe znalazły odzwierciedlenie w wysokich wartościach syntetycznego wskaźnika patriotyzmu lokalnego członków badanych grup. Blisko $80 \%$ z nich uzyskało wartość najwyższą (oznaczającą dużą więź z gminą zamieszkania oraz zaangażowanie w jej sprawy, manifestujące się udziałem w wyborach władz lokalnych), podczas gdy wartość najniższa charakteryzowała zaledwie $2 \%$ tej zbiorowości [tabela 34]. Średnia wartość wskaźnika dla analizowanej grupy (w skali 0-2) wyniosła 1,75 punktu.

Tabela 34. Składowe komponentu norm i wartości - patriotyzm lokalny

\begin{tabular}{|c|c|c|c|c|c|c|}
\hline \multirow{2}{*}{ Patriotyzm lokalny $\left(\mathrm{W}_{1}\right) \mathrm{N}=566$} & \multicolumn{2}{|c|}{$\mathrm{W}_{1}=2$} & \multicolumn{2}{c|}{$\mathrm{W}_{1}=1$} & \multicolumn{2}{c|}{$\mathrm{W}_{1}=0$} \\
\cline { 2 - 8 } & liczba & odsetek & liczba & odsetek & liczba & odsetek \\
\cline { 2 - 8 } & 436 & 77 & 119 & 21 & 11 & 2 \\
\hline
\end{tabular}

Źródło: opracowanie własne. 
W ramach komponentu analizowano także te normy i wartości, które wiązały się z przynależnością członków LGD do tej organizacji. Założono, że aprobata normy działania na rzecz partnerstwa będzie konsekwencją postrzegania go jako obszaru spójnego pod względem przyrodniczym, gospodarczym i kulturowym, a więc jako pewnej szczególnej, odrębnej całości (która sama w sobie stanowi wartość). Świadczyć to może o zrozumieniu istoty partnerstwa i akceptacji ustalonych formalnie sposobów działania z uwzględnieniem jego cech. Co za tym idzie, wśród głównych wyznaczników działania w LGD powinny się znaleźć: chęć reprezentowania interesów partnerstwa oraz chęć nawiązania jak najszerszej współpracy na jego rzecz między wszystkimi członkami grupy, a także przekonanie o konieczności opanowania procedur związanych z funkcjonowaniem LGD.

W celu zbadania powszechności obowiązywania wymienionych norm w lokalnych grupach działania, respondentom zadano pytania o motywy aktywności w tych organizacjach (zarówno ich własne, jak i obserwowane u innych członków LGD) oraz o ich stosunek do opinii mówiącej, że członkowie wszystkich sektorów wchodzących w skład LGD powinni ze sobą współpracować (na rzecz rozwoju gmin tworzących obszar partnerstwa). Powody uczestnictwa w działalności organizacji sprowadzono do czterech kategorii, tj. aktywności na rzecz: a) mieszkańców wszystkich gmin tworzących obszar partnerstwa, b) mieszkańców gminy zamieszkania, c) sektora, do którego należy badany lub d) interesów osobistych. Odsetki wskazań wynosiły odpowiednio: $52,3 \%, 35,8 \%, 9,3 \%$ oraz 2,7\% ogółu. Innymi słowy, w ponad połowie przypadków motywem podejmowanej działalności są nie tyle interesy konkretnej społeczności lokalnej, ile całego partnerstwa. Natomiast tylko około 2,7\% ogółu respondentów otwarcie przyznało, że ich uczestnictwo w LGD jest podyktowane wyłącznie chęcią realizacji interesów osobistych. Deklaracje badanych wydają się zatem świadczyć o ich akceptacji dla idei pracy na rzecz nowej wartości - partnerstwa. Jednocześnie wskazują na fakt, iż członkowie LGD są społecznikami, osobami, które podejmują (w różnym zakresie) działalność w tych organizacjach, przede wszystkim dla dobra ogółu, a nie interesów partykularnych. Tę cechę (omówioną szerzej w kolejnej części pracy) potraktowano jako następny aspekt komponentu norm i wartości.

Warto podkreślić, że prawie połowa badanych przypisała analogiczną motywację aktywności w lokalnej grupie także większości jej członków, uznając, iż działają oni przede wszystkim w imię interesów całego partnerstwa. Niewielki był odsetek respondentów przekonanych, że większość członków organizacji kieruje się interesem osobistym [tabela 35$]$. 
Tabela 35. Opinie badanych na temat interesów reprezentowanych przez większość członków LGD

\begin{tabular}{|l|c|}
\hline \multicolumn{1}{|c|}{$\begin{array}{c}\text { Czyje interesy Pana(i) zdaniem reprezentuje } \\
\text { większość członków LGD? }\end{array}$} & $\begin{array}{c}\text { Odsetek wskazań pozytywnych badanych } \\
\text { z LGD } \\
\text { [w \%], N =573 }\end{array}$ \\
\hline Mieszkańców gmin tworzących obszar partnerstwa & 49,2 \\
\hline Mieszkańców określonej gminy & 35,0 \\
\hline Sektora, do którego należą & 12,1 \\
\hline Osobiste & 3,8 \\
\hline
\end{tabular}

Źródło: opracowanie własne.

Przytoczone przekonanie dotyczące motywów działania w lokalnej grupie może stanowić czynnik ułatwiający jej członkom kooperację. Sprzyja jej również przeświadczenie, że wszyscy członkowie LGD powinni ze sobą współpracować na rzecz rozwoju gmin tworzących obszar partnerstwa, niezależnie od tego, jaki sektor reprezentują (takiego zdania było ponad 90\% badanych), a także (podzielane przez ponad $70 \%$ badanych) przekonanie o tym, że procedury prawne i finansowe (regulujące funkcjonowanie lokalnej grupy działania) powinni znać wszyscy jej członkowie (partnerzy). Kwestią otwartą pozostaje to, w jakim stopniu sfera deklaracji pokrywa się z rzeczywistym działaniem [tabela 36].

Tabela 36. Rozkłady odpowiedzi na pytania wskaźnikowe - normy i wartości LGD

\begin{tabular}{|c|c|c|c|c|c|c|}
\hline \multirow{2}{*}{$\begin{array}{c}\text { Normy i wartości związane } \\
\text { z uczestnictwem w LGD }\end{array}$} & \multicolumn{2}{c|}{$\begin{array}{c}\text { Interesy } \\
\text { partnerstwa }\end{array}$} & \multicolumn{2}{c|}{$\begin{array}{c}\text { Interesy gminy } \\
\text { lub sektora }\end{array}$} & \multicolumn{2}{c|}{ Interesy osobiste } \\
\cline { 2 - 8 } & liczba & odsetek & liczba & odsetek & liczba & odsetek \\
\hline $\begin{array}{l}\text { Chęć reprezentowania interesów } \\
\text { partnerstwa/gminy jako główny mo- } \\
\text { tyw uczestnictwa w LGD (N = 551) }\end{array}$ & 288 & 52,3 & 248 & 45 & 15 & 2,7 \\
\hline & \multicolumn{2}{|c|}{ Tak } & \multicolumn{2}{|c|}{ Nie } & - & - \\
\hline $\begin{array}{l}\text { Przekonanie o potrzebie współpracy } \\
\text { międzysektorowej członków LGD } \\
\text { na rzecz partnerstwa (N = 563) }\end{array}$ & 504 & 89,5 & 59 & 10,5 & - & - \\
\hline
\end{tabular}

Źródło: opracowanie własne.

Wysoki poziom akceptacji poszczególnych norm i wartości (związanych z funkcjonowaniem lokalnej grupy działania) znajduje swoje odzwierciedlenie w stosunkowo wysokich wartościach wskaźnika, który je syntetyzuje. Niemal co drugiemu z badanych przypisano najwyższą jego wartość (w oparciu o deklaro- 
wane przez niego przekonania: o tym, że działając w LGD reprezentuje przede wszystkim interesy całego partnerstwa oraz o tym, że realizacja tych interesów wymaga współpracy przedstawicieli wszystkich sektorów), a tylko dwojgu respondentów wartość najniższą (opartą na negacji wspomnianych przekonań - por. tabela 37). Średnia wartość wskaźnika norm i wartości związanych z przynależnością do LGD wyniosła w badanej zbiorowości 1,49 punktu (w skali obejmującej wartości od 0 do 2 punktów).

Tabela 37. Składowe komponentu norm i wartości - normy/wartości związane z LGD

\begin{tabular}{|c|c|c|c|c|c|c|}
\hline \multirow{2}{*}{$\begin{array}{c}\text { Normy i wartości związane } \\
\text { z uczestnictwem w LGD }\left(\mathrm{W}_{3}\right) \\
\mathrm{N}=544\end{array}$} & \multicolumn{2}{|c|}{$\mathrm{W}_{3}=2$} & \multicolumn{2}{c|}{$\mathrm{W}_{3}=1$} & \multicolumn{2}{c|}{$\mathrm{W}_{3}=0$} \\
\cline { 2 - 8 } & liczba & odsetek & liczba & odsetek & liczba & odsetek \\
\cline { 2 - 8 } & 268 & 49,3 & 274 & 50,4 & 2 & 0,4 \\
\hline
\end{tabular}

Źródło: opracowanie własne.

Kolejną zmienną składową komponentu norm i wartości było społecznikostwo respondentów. Zgodnie z przyjętymi założeniami badawczymi wyrażało się ono deklaracją gotowości do niesienia pomocy innym (m.in. poprzez kontynuację prac na rzecz mieszkańców partnerstwa w strukturze LGD), opartej na wierze we własne siły (poczuciu kontroli nad własnym życiem). Prezentację wyników badania, dotyczących kwestii działalności społecznej członków lokalnych grup działania warto rozpocząć od przypomnienia, że już przed przystąpieniem do LGD około 52\% ogółu respondentów było członkami organizacji pozarządowych, działających na rzecz mieszkańców gminy ${ }^{12}$. Identyczny odsetek respondentów (a więc co druga osoba spośród nich) angażował się także w inicjatywy na rzecz mieszkańców gminy, organizowane przez instytucje i organizacje lokalne. Co trzeci badany zgłaszał potrzebę realizacji jakiegoś przedsięwzięcia ukierunkowanego na dobro mieszkańców wsi. Łącznie, w przypadku aż 75\% badanych, przystąpienie do LGD było poprzedzone zaangażowaniem w jakąś działalność na rzecz gminy i jej mieszkańców. Jednocześnie, mimo wielu zastrzeżeń do sposobu wdrażania w Polsce podejścia LEADER (o czym szerzej w kolejnej części publikacji), 96\% respondentów, którzy udzielili odpowiedzi na pytanie dotyczące zamiaru kontynuacji działalności w ramach LGD, zamierza dalej należeć do tych organizacji.

Przytoczone dane zdają się potwierdzać związek między więzią badanych z miejscem zamieszkania (szerzej - społecznością lokalną) a ich aktywnością na rzecz jej interesów (co koresponduje z wnioskami Suttona i Kolaji na temat zależności między zamieszkiwaniem terytorium a podejmowaniem działań na jego

12 Dokładnej charakterystyce społeczno-politycznej aktywności badanych poświęcono rozdział II niniejszej publikacji. 
rzecz [1960, za: Starosta 1995: 67]). Należy jednak pamiętać, że LGD mają za zadanie nie tyle wspierać rozwój poszczególnych gmin, ile działać na rzecz obszaru spójnego pod względem społeczno-gospodarczym i przyrodniczym (w jego skład czasami wchodzi nawet kilkanaście jednostek samorządu terytorialnego). Powstaje pytanie, czy więź z miejscem zamieszkania nie stanowi przeszkody w podejmowaniu przez respondentów aktywności w LGD. Poziom identyfikacji z własną gminą może wpływać na mniejsze zainteresowanie działaniami na rzecz innych gmin, wchodzących w skład partnerstwa.

Niewątpliwie przeszkody takiej nie stanowi przekonanie o zależności rezultatów podejmowanych działań od własnego w nich udziału, czyli deklarowane poczucie podmiotowości. Jego poziom zweryfikowano, prosząc respondentów o zaznaczenie na skali (od 1 do 10) liczby odzwierciedlającej poczucie kontroli nad własnym losem. Przyjmując, że wartości 8, 9 oraz 10 przemawiają na rzecz wysokiego poziomu poczucia podmiotowości, należy stwierdzić, iż cechowało ono około $58 \%$ badanych. Najniższym poziomem poczucia podmiotowości (liczby od 1 do 3 na skali) cechowało się tylko 3\% ogółu respondentów [tabela 38].

Tabela 38. Rozkłady odpowiedzi na pytania wskaźnikowe - społecznikostwo i podmiotowość

\begin{tabular}{|l|c|c|c|c|c|c|}
\hline \multirow{2}{*}{ Normy społeczne } & \multicolumn{2}{|c|}{ Wysoki } & \multicolumn{2}{c|}{ Średni } & \multicolumn{2}{c|}{ Niski } \\
\cline { 2 - 9 } & liczba & odsetek & liczba & odsetek & liczba & odsetek \\
\hline $\begin{array}{l}\text { Poziom poczucia podmiotowości } \\
\text { respondentów (N = 546) }\end{array}$ & 324 & 57,7 & 221 & 39,3 & 17 & 3 \\
\hline & \multicolumn{2}{|c|}{ Tak } & \multicolumn{2}{|c|}{ Nie } & - & - \\
\hline $\begin{array}{l}\text { Przekonanie, że ludziom należy } \\
\text { pomagać (N = 545) }\end{array}$ & 440 & 80,7 & 105 & 19,3 & - & - \\
\hline
\end{tabular}

Źródło: opracowanie własne.

O poziomie podmiotowości respondentów może także świadczyć ich opinia o tym, czy osoby, takie jak oni, mogą doprowadzić do rozwiązania niektórych problemów swojego środowiska, przyczynić się do tego, by sytuacja w miejscowości czy gminie zmieniła się na lepsze. Odpowiedzi „zdecydowanie tak” oraz „raczej tak” udzieliło w sumie 66\% badanych. Wartości obu zmiennych, które wykorzystano w celu oszacowania ich poczucia podmiotowości, mogą świadczyć o tym, że nie wszyscy cechują się jego najwyższym poziomem, jednak w badanej zbiorowości w zasadzie nie występują osoby, które nie wierzą w efektywność i sensowność podejmowanych działań uważając, iż są tylko nieznaczącym elementem działań (nie ich aktywnym podmiotem). 
Jeśli weźmiemy pod uwagę przeświadczenie większości respondentów o sensie i mocy sprawczej ich pracy, a także wcześniejsze dane dotyczące podejmowanej przez nich aktywności społecznej, nie dziwi deklaracja blisko 81\% ogółu badanych, że według nich ,należy być wrażliwym i gotowym do pomocy innym ludziom” (tylko 20\% grupy uważało, że „trzeba walczyć o swoje sprawy, nie zważając na innych ludzi").

Podsumowując rezultaty badań, związanych z kwestiami społecznikostwa i podmiotowości respondentów, należy zauważyć, że niemal co drugiego z ankietowanych członków LGD cechowało poczucie wysokiego poziomu kontroli nad własnym życiem (podmiotowości) oraz przeświadczenie o konieczności uwzględniania dobra innych ludzi podczas realizowania własnych interesów (wykazywania się wrażliwością na ich potrzeby i gotowością niesienia pomocy). Osób, skupionych wyłącznie na realizacji własnych interesów i jednocześnie cechujących się poczuciem co najwyżej umiarkowanej kontroli nad własnym życiem, znalazło się w badanej grupie tylko pięć [tabela 39]. Średnia wartość wskaźnika prezentowanej zmiennej syntetycznej wyniosła (w badanej grupie) 1,48 punktu (w skali 0-2).

Tabela 39. Składowe komponentu norm i wartości - społecznikostwo i poczucie podmiotowości

\begin{tabular}{|c|c|c|c|c|c|c|}
\hline & \multicolumn{2}{|c|}{$\begin{array}{c}\mathrm{W}_{2}=2 \\
\text { Gotowość do pomo- } \\
\text { cy innym ludziom, } \\
\text { wysoki poziom } \\
\text { podmiotowości } \\
\text { podmiotowości }\left(\mathrm{W}_{2}\right) \mathrm{N}=536\end{array}$} & \multicolumn{2}{|c|}{$\mathrm{W}_{2}=1$} & \multicolumn{2}{c|}{$\begin{array}{c}\mathrm{W}_{2}=0 \\
\text { Brak gotowości } \\
\text { do pomocy innym } \\
\text { ludziom, niski lub } \\
\text { średni poziom } \\
\text { podmiotowości }\end{array}$} \\
\cline { 2 - 8 } & liczba & odsetek & liczba & odsetek & liczba & odsetek \\
\cline { 2 - 8 } & 262 & 49 & 269 & 50 & 5 & 1 \\
\hline
\end{tabular}

Źródło: opracowanie własne.

Wysokie wartości wskaźników wszystkich zmiennych cząstkowych, wchodzących w skład syntetycznego komponentu norm i wartości przełożyły się wprost także na wartość jego miary zbiorczej. Wśród członków lokalnych grup działania, dla których oszacowanie wartości tego komponentu było możliwe (508 osób) nie znalazła się ani jedna osoba, której przypisano by najniższe możliwe wartości wskaźnika (0-1), oznaczające brak więzi z miejscem zamieszkania, niechęć do (współ)pracy dla dobra partnerstwa, zgeneralizowane przekonanie o bezsensowności podejmowania działań na rzecz innych ludzi oraz niskie poczucie kontroli nad własnym życiem. Jednocześnie ponad $60 \%$ respondentów uzyskało wartości wskaźnika (5-6 punktów), świadczące o ich patriotyzmie lokalnym, przekonaniu o dużej wartości wspólnej pracy wszystkich członków grupy na rzecz interesów partnerstwa, wysokim poziomie społecznikostwa i podmiotowości [por. wykres 2]. 
Wykres 2. Poziom komponentu norm i wartości w badanych LGD

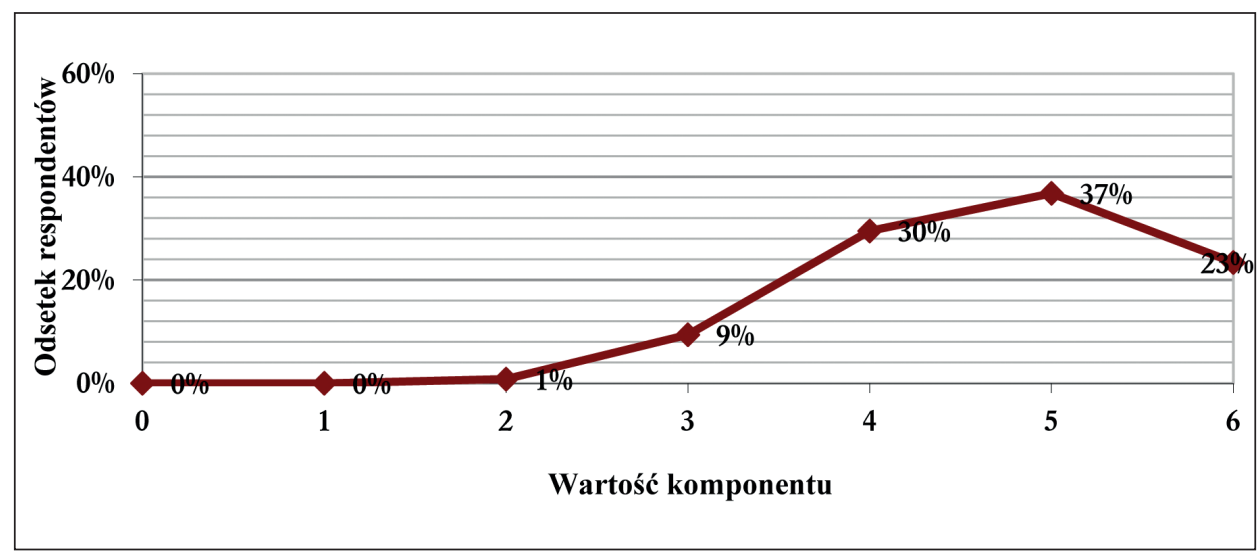

Źródło: opracowanie własne.

Średnia wartość komponentu norm i wartości w badanej grupie wyniosła 4,73 punktu (w skali od 0 do 6 punktów) i okazała się najwyższa wśród średnich wartości wszystkich komponentów kapitału społecznego.

Ostatni z analizowanych komponentów kapitału społecznego, komponent sieci powiązań (opartych na określonym zaufaniu oraz podzielanych normach i wartościach), łączących członków lokalnych grup działania, charakteryzowano za pomocą trzech zmiennych. Pierwszą z nich było zaangażowanie respondentów w sieci współpracy na rzecz społeczności lokalnej (partnerstwa lub gminy), wyrażające się podejmowaniem prac na rzecz mieszkańców gminy ${ }^{13}$ oraz uczestnictwem w promowaniu lokalnej kultury. Jako drugą zmienną przyjęto uczestnictwo respondentów w pracach LGD, w ramach którego wzięto pod uwagę: (a) poziom aktywności w pracach LGD (szacowany w relacji do średniego poziomu aktywności wykazywanego przez członków grupy), który uzupełniono informacjami dotyczącymi częstotliwości udziału respondentów w spotkaniach LGD; (b) formy podejmowanej aktywności (od uczestnictwa wyłącznie formalnego, poprzez aktywność werbalną na zebraniach LGD, po udział w inicjatywach grupy). W nawiązaniu do tego aspektu komponentu sieci (ale nie włączając tych danych do jego zbiorczego indeksu) scharakteryzowano także efektywność przepływu informacji o spotkaniach grupy, rodzaje organizowanych spotkań, najważniejsze

13 Poziom aktywności badanych oceniano na podstawie liczby typów działań, w które angażował się respondent. Jako odrębne typy aktywności wzięto pod uwagę: sprawowanie funkcji publicznych (radny, sołtys, wójt), pracę w instytucjach lokalnych (Urząd Gminy, GOPS, GOK itp.), pracę w organizacjach pozarządowych, sponsoring oraz inicjowanie działań i przedsięwzięć na rzecz społeczności lokalnej, udział w takich inicjatywach oraz inicjowanie protestów przeciw działaniom niekorzystnym dla lokalnej społeczności. 
wśród zrealizowanych projektów ${ }^{14}$. Trzecią zmienną decydującą o wartości komponentu sieci było poczucie wpływu członków LGD na funkcjonowanie partnerstwa, w skład którego wchodziły takie zmienne składowe, jak ich partycypacja w procesach decyzyjnych grupy oraz przekonanie o pozytywnym wpływie działań struktury na rozwój obszaru partnerstwa. Dodatkową informacją związaną z ostatnią składową komponentu sieci było wyszczególnienie elementów sieci w największym stopniu zaangażowanych w pracę grupy. Stanowiła ona pochodną ustaleń dotyczących poziomu aktywności w sieci członków LGD, pełniących różne funkcje, składu społecznego grup oraz wiedzy ich członków na temat zasad rozwoju wielofunkcyjnego i zrównoważonego.

Prezentowane wcześniej deklaracje badanych, dotyczące ich gotowości do zaangażowania się w prace służące realizacji interesów mieszkańców gmin wchodzących w skład partnerstwa znalazły swoje odbicie także w udostępnionych przez nich informacjach dotyczących działań rzeczywiście realizowanych. Niemal trzy czwarte respondentów, niezależnie od przynależności do LGD, aktywnie działało na rzecz mieszkańców, bądź to w ramach instytucji publicznych (np. jako urzędnicy, radni, wójtowie), bądź to w organizacjach pozarządowych, bądź też prywatnie, indywidualnie lub $\mathrm{w}$ porozumieniu z innymi mieszkańcami gminy. W przypadku $60 \%$ osób zaangażowanych w działania na rzecz gminy/partnerstwa (i niespełna 44\% ogółu badanych) aktywność ta realizowała się w jednej, maksymalnie dwóch formach, tzn. brali oni udział np. tylko w przedsięwzięciach podejmowanych przez lokalne instytucje publiczne lub tylko w przedsięwzięciach organizacji pozarządowej, do której należeli. Jednak dla 30\% najbardziej aktywnych respondentów zaangażowanie w sprawy partnerstwa/gminy oznaczało udział w trzech lub większej liczbie typów przedsięwzięć inicjowanych zarówno przez różne instytucje, jak i podejmowanych z własnej inicjatywy.

O znaczącym zaangażowaniu respondentów w sprawy społeczności lokalnej świadczy także fakt, że prawie $71 \%$ spośród nich (zanim przystąpiło do LGD) uczestniczyło $\mathrm{w}$ wydarzeniach związanych $\mathrm{z}$ promowaniem kulturowego dziedzictwa obszaru objętego działaniami organizacji [tabela 40].

Informacje dotyczące aktywności respondentów przetransponowano na zmienną wyrażającą ich zaangażowanie w sieci współpracy na rzecz partnerstwa lub gminy w postaci pojedynczej wartości liczbowej (z przedziału 0-2 punkty). Zgodnie z oczekiwaniami, tylko niewielki odsetek badanej zbiorowości (14\% ogółu) uzyskał najniższą wartość omawianej zmiennej, oznaczającą brak zaangażowania w jakiekolwiek działania na rzecz gminy/partnerstwa (w tym brak uczestnictwa w przedsięwzięciach związanych z promowaniem lokalnej kultury), zaś co

${ }^{14}$ Ta zmienna będzie poddana analizie w kolejnej części pracy. Jej celem będzie porównanie struktury kapitału społecznego LGD z dwóch zbiorów. Podstawą porównania (zgodnie z przedstawionym w części metodologicznej uzasadnieniem) będzie losowa redukcja liczby LGD z drugiego zbioru. Dane dotyczące najważniejszych ze zrealizowanych projektów będą więc dotyczyły organizacji wybranych do analizy. 
Tabela 40. Rozkłady odpowiedzi na pytania wskaźnikowe - praca na rzecz partnerstwa/gminy

\begin{tabular}{|l|c|c|c|c|c|c|c|}
\hline \multirow{2}{*}{$\begin{array}{c}\text { Zaangażowanie w sieci współ- } \\
\text { pracy na rzecz partnerstwa/gminy }\end{array}$} & \multicolumn{2}{|c|}{$\begin{array}{c}\text { Udział w wielu ty- } \\
\text { pach przedsięwzięć }\end{array}$} & \multicolumn{2}{c|}{$\begin{array}{c}\text { Udział w 1-2 ty- } \\
\text { pach przedsięwzięć }\end{array}$} & \multicolumn{2}{|c|}{$\begin{array}{c}\text { Brak udziału } \\
\text { w przedsięwzięciach }\end{array}$} \\
\cline { 2 - 8 } & liczba & odsetek & liczba & odsetek & liczba & odsetek \\
\hline $\begin{array}{l}\text { Praca na rzecz mieszkańców } \\
\text { gminy (N = 561) }\end{array}$ & 170 & 30,3 & 245 & 43,7 & 146 & 26 \\
\hline & \multicolumn{3}{|c|}{ Tak } & \multicolumn{2}{|c|}{ Nie } & - & - \\
\hline $\begin{array}{l}\text { Uczestnictwo w promowaniu } \\
\text { lokalnej kultury (N = 565) }\end{array}$ & 401 & 71 & 164 & 29 & - & - \\
\hline
\end{tabular}

Źródło: opracowanie własne.

czwartemu z respondentów można było przypisać najwyższą wartość zmiennej, oznaczającą zaangażowanie w różne typy działań na rzecz lokalnej społeczności (w tym w promowanie kultury lokalnej) [tabela 41]. Tym samym średni poziom omawianej zmiennej wyniósł w badanej zbiorowości 1,11 punktu.

Tabela 41. Składowe komponentu sieci - współpraca na rzecz partnerstwa lub gminy

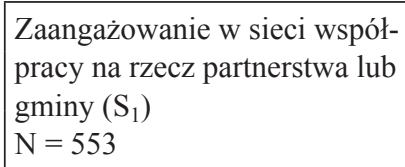

\begin{tabular}{|c|c|c|c|c|c|}
\hline \multicolumn{2}{|c|}{$\mathrm{S}_{1}=2$} & \multicolumn{2}{c|}{$\mathrm{S}_{1}=1$} & \multicolumn{2}{c|}{$\mathrm{S}_{1}=0$} \\
\hline liczba & odsetek & liczba & odsetek & liczba & odsetek \\
\hline 139 & 25,1 & 336 & 60,8 & 78 & 14,1 \\
\hline
\end{tabular}

Źródło: opracowanie własne.

Także aktywność respondentów w ramach samej LGD przybrała różne formy. Jedną z nich było partycypowanie w różnych zebraniach członków organizacji. W czasie realizacji PPL+ można je było podzielić na zebrania członków zarządu, komisji rewizyjnej oraz walne zebrania wszystkich członków. W nowym okresie programowania wyszczególniono w strukturze LGD nowy organ - radę, której posiedzenia dotyczą przede wszystkim oceny wniosków złożonych przez różnych beneficjentów do LGD.

W opinii badanych, zebrania członków zarządu (w zeszłym okresie programowania) odbywały się raz w miesiącu (35,7\% wskazań) lub nawet rzadziej (44,5\% wskazań). W obecnym okresie programowania ich częstotliwość jest podobna ${ }^{15}$. Nie zmieniła się również intensywność zwoływania walnych zebrań - odbywają się one rzadziej niż raz w miesiącu - najczęściej raz czy dwa razy do roku (tylko około $41 \%$ badanych zadeklarowało, że zawsze w nich uczestniczy). Nowy organ

15 Około 40\% badanych stwierdziło, że odbywają się raz w miesiącu, ponad 42\%, że rzadziej. 
lokalnych grup działania - rada - obraduje podobnie (tj., zgodnie z wiedzą $81 \%$ respondentów, rzadziej niż raz w miesiącu).

Około trzech piątych badanych (niemal 64\% ogółu) stwierdziło, że (obecnie) ich aktywność w lokalnych grupach działania jest podobna do tej, którą wykazują inni jej członkowie (co czwarty podkreślił, iż jest ona nawet większa). Około 55\% respondentów zadeklarowało jednocześnie, że podstawową formę ich aktywności stanowi działalność w różnego rodzaju inicjatywach grupy. Pozostali (31\%) przyznali, iż ich aktywność w grupie sprowadza się tylko do zabierania głosu w czasie spotkań. W zbiorowości respondentów można wyszczególnić również tych, którzy otwarcie przyznają, że nie angażują się w funkcjonowanie LGD, są jej członkami (partnerami) tylko formalnie (taką deklarację złożyło prawie 14\% ich ogółu) [tabela 42].

Tabela 42. Rozkłady odpowiedzi na pytania wskaźnikowe - udział w działaniach LGD

\begin{tabular}{|l|c|c|c|c|c|c|}
\hline \multirow{2}{*}{$\begin{array}{c}\text { Uczestnictwo } \\
\text { w pracach LGD }\end{array}$} & \multicolumn{2}{|c|}{ Ponadprzeciętny } & \multicolumn{2}{c|}{ Przeciętny } & \multicolumn{2}{c|}{ Poniżej przeciętnego } \\
\cline { 2 - 7 } & liczba & odsetek & liczba & odsetek & liczba & odsetek \\
\hline $\begin{array}{l}\text { Poziom aktywności } \\
(\mathrm{N}=569)\end{array}$ & 137 & 24,1 & 362 & 63,6 & 70 & 12,3 \\
\hline & \multicolumn{2}{|c|}{$\begin{array}{c}\text { Aktywny udział w re- } \\
\text { alizacji inicjatyw }\end{array}$} & $\begin{array}{c}\text { Udział w dyskusjach, } \\
\text { opiniowanie przedsię- } \\
\text { wzięć }\end{array}$ & $\begin{array}{c}\text { Wyłącznie formalne } \\
\text { uczestnictwo }\end{array}$ \\
\hline $\begin{array}{l}\text { Typ aktywności } \\
(\mathrm{N}=564)\end{array}$ & 308 & 54,6 & 173 & 30,7 & 83 & 14,7 \\
\hline
\end{tabular}

Źródło: opracowanie własne.

Gdy respondentów aktywnych w niewielkim stopniu oraz biernych zapytano o powody takiego stanu rzeczy, najczęściej wskazywali na brak czasu (39\% odpowiedzi) oraz podkreślali, że są przekonani, iż to inni członkowie LGD w działaniach sprawdzą się lepiej (39\% odpowiedzi). Warto dodać, że około 14\% tej kategorii respondentów chciałoby się zaangażować w funkcjonowanie LGD, jednak nie ma takiej możliwości, ponieważ różne prace wykonują ciągle te same osoby.

Znaczące jest, że aż 11\% badanych aktywnych w niewielkim stopniu oraz biernych nie uczestniczyło w realizacji inicjatyw na rzecz mieszkańców gmin tworzących obszar partnerstwa, ponieważ nie byli o nich informowani. Świadczy to o tym, iż różne sposoby komunikacji między organami LGD, ich biurem a członkami (partnerami) zwyczajnymi nie przez wszystkich są oceniane pozytywnie. Każda z tych organizacji decyduje o tym, czy informacje o działaniach będą zamieszczane na stronie internetowej, przekazywane członkom (partnerom) w formie pisemnej (pocztą tradycyjną lub internetową) czy telefoniczne. 
Niezależnie od tego, który ze sposobów (i w jakiej sytuacji) jest wykorzystywany, niektórzy respondenci mają do nich zastrzeżenia.

Podsumowując rezultaty dotyczące uczestnictwa badanych w pracach LGD, warto zwrócić uwagę na zastanawiająco niską częstotliwość zebrań zarządu, która może wskazywać m.in. na bardzo dużą rolę biura w funkcjonowaniu tych organizacji. W literaturze przedmiotu podkreślano, iż problemem LGD może być zbyt wysoki poziom ich profesjonalizacji i ekonomizacji (zob. Zajda 2011), ograniczający możliwość udziału w codziennym funkcjonowaniu organizacji tym członkom (partnerom), którzy nie dysponują odpowiednimi kompetencjami. Wydaje się, że LGD z takim problemem się nie zmagają. Jak wspominano przy okazji analizy norm i wartości kierujących postępowaniem członków badanych LGD, około $71 \%$ badanych zgodziło się z opinią, iż procedury prawne i finansowe (regulujące funkcjonowanie lokalnej grupy działania) powinni znać wszyscy jej członkowie (partnerzy). Innymi słowy, zdecydowana większość z nich jest świadoma uwarunkowań aktywności w LGD. Znajomość specyfiki ich działania ułatwia partycypowanie w nich. Złożone przez respondentów deklaracje świadczą o tym, że ich profesjonalizacja i ekonomizacja są zjawiskami dobrze im znanymi. Odróżniają oni aktywność w LGD od tej, którą często podejmowali w wiejskich organizacjach pozarządowych. Warto dodać, iż 54\% ich ogółu stwierdziło, że wdrażanie PPL+ było trudne, wymagało dużego zaangażowania, podnoszenia umiejętności, kompetencji (zwłaszcza w obliczu skomplikowanych procedur biurokratycznych). Nabyte doświadczenie procentuje w obecnym okresie programowania - kolejną odsłonę realizacji podejścia LEADER badani ocenili nieco lepiej, około $46 \%$ respondentów było zdania, że jej wdrożenie jest trudne.

Jednocześnie, ograniczając analizę wyłącznie do bezpośredniej aktywności członków LGD, należy podkreślić, iż zdecydowana większość badanych oceniła jej poziom jako co najmniej przeciętny na tle innych członków LGD i stwierdziła, że aktywnie partycypuje $\mathrm{w}$ realizacji projektów $\mathrm{LGD}^{16}$. Tym samym odsetek respondentów, którzy osiągnęli najniższą wartość zbiorczego wskaźnika uczestnictwa w pracach LGD (syntetyzującego wymiary poziomu i formy podejmowanej aktywności) był stosunkowo niski (niespełna 8\% ogółu), podczas gdy więcej niż co piątemu z respondentów przypisano jego najwyższą wartość [tabela 43]. Średnia wartość wskaźnika (w standaryzowanej skali od 0 do 2 punktów) w badanej grupie wyniosła 1,14 punktu.

${ }^{16}$ Pozostaje pytanie, w jaki dokładnie sposób? Czy biorąc udział w ich organizacji, zarządzaniu nimi, czy uczestnicząc tylko w charakterze ich beneficjentów. Zebrany (w badaniu ilościowym) materiał nie pozwala na udzielenie odpowiedzi na powyższe pytanie. 
Tabela 43. Składowe komponentu sieci - uczestnictwo w pracach LGD

\begin{tabular}{|l|c|c|c|c|c|c|}
\hline \multirow{2}{*}{$\begin{array}{l}\text { Uczestnictwo w pracach LGD }\left(\mathrm{S}_{2}\right) \\
\mathrm{N}=560\end{array}$} & \multicolumn{2}{|c|}{$\mathrm{S}_{2}=2$} & \multicolumn{2}{c|}{$\mathrm{S}_{2}=1$} & \multicolumn{2}{c|}{$\mathrm{S}_{2}=0$} \\
\cline { 2 - 8 } & liczba & odsetek & liczba & odsetek & liczba & odsetek \\
\cline { 2 - 8 } & 123 & 22 & 393 & 70,2 & 44 & 7,9 \\
\hline
\end{tabular}

Źródło: opracowanie własne.

Działalność LGD wymaga ciągłego zaangażowania co najmniej kilku osób (co stanowi kolejne świadectwo ich profesjonalizacji). Ich praca jest oceniana pozytywnie. Ponad 73\% badanych stwierdziło, iż jej głównym powodem jest chęć działania na rzecz mieszkańców wszystkich gmin tworzących obszar partnerstwa. Jednocześnie odpowiednio około 16\% respondentów wskazało również chęć zdobycia doświadczenia zawodowego. Tylko 8\% ogółu stwierdziło, że liderom LGD zależy głównie na zarobieniu dodatkowych pieniędzy ${ }^{17}$, a zatem są oni postrzegani jako społecznicy, wykonujący odpowiedzialną pracę nie tyle na rzecz interesów osobistych, ile na rzecz rozwoju partnerstwa.

Największą wiedzę na temat funkcjonowania LGD mają ich liderzy. W strukturze tych organizacji można wyszczególnić osoby zaangażowane w działalność w największym stopniu. Prawie połowa (45\%) badanych wyszczególniła więcej niż 5 takich osób.

Liderzy są najczęściej członkami zarządu i rad lokalnych grup działania. W badanej próbie osób należących do LGD znalazło się 23\% członków zarządu, $30 \%$ członków rady, niespełna $6 \%$ członków reprezentujących komisje rewizyjne oraz 42\% członków zwyczajnych ${ }^{18}$. Przechodząc do krótkiej charakterystyki aktywności tych pierwszych w LGD, należy podkreślić, że około 75\% z nich należy do tych organizacji od czasu wdrażania PPL+ (pozostali zapewne przystapili do nich po poszerzeniu składu partnerstwa o nowe gminy). Są to osoby uczestniczące w realizacji podejścia LEADER od początku jego implementacji. Już w czasie realizacji PPL+ zdecydowana większość z nich (75\%) uczestniczyła w różnych inicjatywach grupy. Obecnie taką aktywność wykazuje identyczny ich odsetek. Co ciekawe, nie wszyscy z tych badanych uważają, że w związku z tym ich aktywność jest wyższa od tej, jaką wykazuje większość członków LGD (takiego zdania jest tylko $45 \%$ badanych).

Członkowie zarządu różnią się między sobą formą podejmowanej aktywności i wiedzą na temat realizacji podejścia LEADER. Tylko 38\% z nich za-

${ }_{17}$ Przytoczone odsetki odpowiedzi nie sumują się do 100, ponieważ respondenci mogli wybrać kilka odpowiedzi z kafeterii.

${ }^{18}$ Dane te (wraz z informacjami dotyczącymi przekonań respondentów na temat wpływu LGD na rozwój partnerstwa) stanowiły podstawę obliczenia zbiorczej wartości zmiennej wpływu na funkcjonowanie grupy, co zaprezentowano w tabeli 20. i w dalszej części pracy. 
deklarowało, iż znany jest im termin rozwój wielofunkcyjny. Zdecydowanie więcej - 54\% - złożyło podobną deklarację na temat terminu rozwój zrównoważony. Jak podkreślono w poprzedniej części pracy, samoocena badanych w tym zakresie często pozostaje w sprzeczności z ich faktyczną wiedzą. Nieznajomość tych kategorii pojęciowych jest znacząca, ponieważ utrudnia zrozumienie polityki przemian obszarów wiejskich, co z kolei pozostaje w związku z oceną stopnia trudności realizacji PPL + oraz czwartej osi PROW 2007-2013. Podobny odsetek respondentów uznał, że i pierwszy, i drugi program poświęcony wdrażaniu podejścia LEADER był trudny do wdrożenia (w pierwszym przypadku taką deklarację złożyło 52\%, w drugim 56\% badanych).

Charakteryzując członków rady LGD, trzeba podkreślić, że około $56 \%$ z nich należy do LGD od czasu realizacji PPL+. Nieco ponad połowa z nich $(56 \%)$ $\mathrm{w}$ tamtym czasie brała udział w realizacji różnych inicjatyw grupy. Obecnie tego rodzaju aktywność wykazuje podobny ich odsetek (67\%).

Tylko co trzeci (35\%) członek rady deklaruje, że spotkał się z terminem rozwój wielofunkcyjny, a 48\%, iż znany jest im termin rozwój zrównoważony. Około $55 \%$ ogółu członków tego organu stwierdziło, że PPL+ był trudny do wdrożenia, mniejszy odsetek (43\%) podobnie ocenił wdrażanie 4 osi LEADER.

A zatem, w strukturze LGD można wyróżnić organy aktywne w największym stopniu, skupiające ich liderów. Między nimi istnieją istotne różnice (nie tylko w zakresie wykonywanych obowiązków). Członkowie zarządu częściej niż członkowie rady należą do LGD od czasu realizacji PPL+, częściej również uczestniczą w realizacji różnych inicjatyw grupy (a więc nie tylko zabierają głos na posiedzeniach zarządu, lecz także biorą czynny udział w realizacji projektów LGD). Zauważalna jest różnica poziomu wiedzy badanych (z tych dwóch organów) na temat specyfiki rozwoju wielofunkcyjnego i zrównoważonego ${ }^{19}$. Członkowie zarządu częściej deklarują, że są jej świadomi. Co ciekawe, również oni częściej niż członkowie rady oceniają wdrażanie osi 4 PROW 2007-2013 jako trudne. Nie wynika to z niższego poziomu kompetencji, ale wręcz odwrotnie $-\mathrm{z}$ lepszej znajomości złożonych procedur związanych z jego implementacją.

Konkludując, porównanie zarządu oraz rady LGD wykazuje, że badani należący do pierwszej z wymienionych struktur częściej dysponują doświadczeniem związanym z realizacją podejścia LEADER w okresie 2004-2006. Tym niemniej odsetek członków biernych zarządu i rady jest identyczny (8\%) - zarówno w jednej, jak i w drugiej strukturze znajdują się osoby przypadkowe, których uczestnictwo $\mathrm{w}$ nich może być podyktowane ograniczeniami proceduralnymi albo nieformalnymi porozumieniami między aktorami zaangażowanymi $\mathrm{w}$ proces tworzenia LGD.

19 Dla porównania, wiedza w tym zakresie członków komisji rewizyjnej jest jeszcze mniejsza - 17\% jej członków zadeklarowało, że spotkało się z terminem rozwój wielofunkcyjny, a 33\% $\mathrm{z}$ terminem rozwój zrównoważony. 
Krytyczny stosunek znacznej części badanych do procedur wdrażania w Polsce podejścia LEADER nie oznacza, że nie dostrzegają oni efektów podejmowanych przez te organizacje działań. Ich opinie w tym zakresie - por. tabela 44.

Tabela 44. Opinie badanych na temat efektów wdrażania podejścia LEADER

\begin{tabular}{|l|c|}
\hline \multicolumn{1}{|c|}{ Dotychczasowe funkcjonowanie LGD sprzyjało } & $\begin{array}{c}\text { Odsetek wskazań pozytywnych } \\
\mathrm{N}=468\end{array}$ \\
\hline Promocji gmin tworzących obszar partnerstwa & 87,6 \\
\hline Rozwojowi kwalifikacji i umiejętności członków LGD & 76,9 \\
\hline $\begin{array}{l}\text { Zaangażowaniu mieszkańców gmin tworzących obszar } \\
\text { partnerstwa w działalność na rzecz ich rozwoju }\end{array}$ & 76,7 \\
\hline $\begin{array}{l}\text { Integracji członków LGD, której efektem jest wspólna praca } \\
\text { na rzecz wszystkich gmin tworzących obszar partnerstwa }\end{array}$ & 75,5 \\
\hline $\begin{array}{l}\text { Rozwojowi pozarolniczej działalności gospodarczej } \\
\text { na obszarze gmin tworzących obszar partnerstwa }\end{array}$ & 65,9 \\
\hline $\begin{array}{l}\text { Zmniejszeniu poziomu bezrobocia wśród mieszkańców gmin } \\
\text { tworzących obszar partnerstwa }\end{array}$ & 29,3 \\
\hline
\end{tabular}

Źródło: opracowanie własne.

Respondenci do efektów realizacji podejścia LEADER zaliczyli przede wszystkim promocję gmin wchodzących w skład obszaru partnerstwa. Już w czasie realizacji schematu II PPL+ organizacje te mogły wydawać środki np. na różnego rodzaju inwentaryzacje i opis lokalnych zasobów, głównie tych, których wykorzystanie mogło przyczynić się do dywersyfikacji działalności gospodarczej prowadzonej na ich obszarze. Promocja, z jednej strony, służyła rozwojowi (najczęściej) mikro- i małych przedsiębiorstw, z drugiej - oddziaływała na tożsamość mieszkańców tych gmin. Niektórzy z nich przystąpili do lokalnych grup działania, inni stali się beneficjentami ich pomocy (np. biorąc udział w organizowanych konkursach z działania „Małe projekty”, „Tworzenie i rozwój mikroprzedsiębiorstw”, „Różnicowanie w kierunku działalności nierolniczej”). Sprzyjało to ich aktywizacji.

Mniejszy odsetek badanych podziela opinię, że dotychczasowa działalność LGD sprzyjała rozwojowi kwalifikacji i umiejętności członków LGD oraz ich integracji. Aktywne członkostwo w LGD wymagało nabycia nowej wiedzy, nie tylko dotyczącej różnych procedur wrażania podejścia LEADER, lecz także przemian wsi. W poprzedniej części pracy wykazano, iż respondenci (nawet z zarządów i rad tych organizacji) mają problem z określeniem znaczenia terminów, podstawowych dla paradygmatu odnowy i przemian Wspólnej Polityki Rolnej. Świadczy to o konieczności dalszego inwestowania w zasoby ludzkie lokalnych grup działania. 
Najmniejszy odsetek badanych sądzi, że dotychczasowe ich funkcjonowanie sprzyjało zmniejszeniu poziomu bezrobocia wśród mieszkańców gmin tworzących obszar partnerstwa. Podejmowana przez nie w tym zakresie działalność może mieć wiele obliczy. Sprowadza się do szkoleń organizowanych dla bezrobotnych (ukierunkowanych na nabycie nowych kompetencji zawodowych), ale też obejmuje dofinansowanie działalności już istniejących (lub nowo powstałych) firm. O ile łatwo policzyć środki wydane na szkolenia, określić liczbę zrealizowanych osobogodzin, o tyle trudniej śledzić losy ich absolwentów lub wprost zagwarantować im jakąś pracę. Członkowie lokalnych grup działania doceniają podejmowaną przez siebie aktywność, szacują, że przyczynia się ona do redukcji bezrobocia. Bez pogłębionych badań w tym zakresie trudno im jednak dokładnie oszacować skalę tego wpływu.

Jeśli deklaracje respondentów uznać za wskaźnik dotychczasowych osiągnięć lokalnych grup działania, to wydawać by się mogło, że w zasadzie sprowadzają się one do promocji partnerstwa oraz kształtowania samych struktur. Chodzi tu o kapitał ludzki (w tym kwalifikacje i umiejętności), jakim dysponują ich członkowie i partnerzy (zwłaszcza w największym stopniu aktywni) oraz o kapitał społeczny, czyli potencjał do działania, wynikający z istnienia względnie zintegrowanej sieci współpracy. Konkluzję taką zdaje się jednak podważać wysoki odsetek badanych dostrzegających, iż pozytywne oddziaływanie LGD nie sprowadza się wyłącznie do podnoszenia ,jakości” struktury (co samo w sobie powinno przyczyniać się także do zwiększenia efektywności jej działań, z założenia nakierowanych na realizację interesów partnerstwa), ale niezależnie od niej daje się zaobserwować także $\mathrm{w}$ innych obszarach funkcjonowania partnerstwa (łącznie $89 \%$ badanych wskazuje co najmniej jeden z procesów zachodzących poza samą LGD, z czego większość - 70\% analizowanej grupy - nie ogranicza się tylko do jednego wskazania).

Na potrzeby dalszych analiz odpowiedzi pozytywne na wszystkie pytania dotyczące wpływu LGD na rozwój partnerstwa (zaprezentowane powyżej) zsumowano, po czym uzyskane wyniki poddano transformacji do postaci trójwartościowej. Wartość najniższa oznaczała przekonanie o braku wpływu LGD na funkcjonowanie gmin objętych działaniami grupy (i poprawy jakości życia ich mieszkańców), zaś wartość najwyższa - poczucie, iż aktywność organizacji wywołuje pozytywne efekty co najmniej w 5 z 6 wymienionych sfer. Przeprowadzona procedura pozwoliła stwierdzić, że ponad $90 \%$ respondentów dostrzega pozytywne efekty oddziaływania LGD na procesy społeczno-gospodarcze zachodzące na obszarze, do pracy na rzecz którego grupa została powołana (z czego połowa dostrzega je $\mathrm{w}$ wielu sferach funkcjonowania partnerstwa). Tylko $8 \%$ badanych nie widzi wpływu prac grupy na stan partnerstwa [tabela 45]. 
Tabela 45. Rozkłady odpowiedzi na pytania wskaźnikowe

- wpływ na funkcjonowanie partnerstwa

\begin{tabular}{|c|c|c|c|c|c|c|}
\hline \multirow[t]{2}{*}{$\begin{array}{c}\text { Poczucie wpływu na funkcjo- } \\
\text { nowanie partnerstwa }\end{array}$} & \multicolumn{2}{|c|}{$\begin{array}{l}\text { Najwyższy wpływ } \\
\text { na decyzje dotyczące } \\
\text { LGD (zarząd, rada) }\end{array}$} & \multicolumn{2}{|c|}{$\begin{array}{c}\text { Umiarkowany } \\
\text { wpływ na decyzje } \\
\text { (komisja rewizyjna) }\end{array}$} & \multicolumn{2}{|c|}{$\begin{array}{l}\text { Najniższy wpływ } \\
\text { na decyzje (członek } \\
\text { zwyczajny) }\end{array}$} \\
\hline & liczba & odsetek & liczba & odsetek & liczba & odsetek \\
\hline \multirow[t]{2}{*}{$\begin{array}{l}\text { Partycypacja w procesach } \\
\text { decyzyjnych grupy }(\mathrm{N}=561)\end{array}$} & 296 & 52,8 & 31 & 5,5 & 234 & 41,7 \\
\hline & \multicolumn{2}{|c|}{$\begin{array}{l}\text { Wpływ LGD } \\
\text { na rozwój wielu sfer }\end{array}$} & \multicolumn{2}{|c|}{$\begin{array}{l}\text { Wpływ LGD } \\
\text { na rozwój kilku sfer }\end{array}$} & \multicolumn{2}{|c|}{$\begin{array}{l}\text { Brak wpływu LGD } \\
\text { na rozwój } \\
\text { partnerstwa }\end{array}$} \\
\hline $\begin{array}{l}\text { Przekonanie o wpływie działań } \\
\text { LGD na rozwój partnerstwa } \\
(\mathrm{N}=458)\end{array}$ & 210 & 45,9 & 210 & 45,9 & 38 & 8,3 \\
\hline
\end{tabular}

Źródło: opracowanie własne.

Podsumowując wyniki dotyczące poczucia wpływu na funkcjonowanie partnerstwa, warto jeszcze zwrócić uwagę na fakt, iż przekonanie o znaczącym wpływie działań LGD na rozwój wielu sfer związanych z funkcjonowaniem partnerstwa podziela większy odsetek respondentów, mających największy udział w decyzjach dotyczących prac lokalnej grupy, niż ma to miejsce w przypadku respondentów o niższym poziomie decyzyjności. Różnica między członkami zarządów i rad badanych LGD a pozostałymi ich członkami wynosi w przypadku tej zmiennej 10 punktów procentowych (opinię o szerokim zakresie wpływu organizacji na obszar partnerstwa podziela 51\% badanych, pełniących najwyższe funkcje w LGD, podczas gdy wśród pozostałych członków grupy odsetek ten wynosi około 41\%). A zatem realny wpływ na działania LGD wydaje się do pewnego stopnia przekładać na poczucie stosunkowo większego wpływu także na losy partnerstwa.

Syntetyczny wskaźnik poczucia wpływu na funkcjonowanie partnerstwa, skonstruowany w oparciu o dane dotyczące funkcji pełnionych w lokalnej grupie działania (przekładających się na określony poziom partycypacji w najważniejszych decyzjach dotyczących podejmowanych w niej przedsięwzięć oraz przekonań na temat wpływu LGD na funkcjonowanie gmin znajdujących się na obszarze jej działania), osiągnął w badanej grupie stosunkowo wysoką średnią wartość równą 1,23 punktu (w skali 0-2). Na podstawie wyników uzyskanych w wyniku agregacji i transformacji przywołanych zmiennych cząstkowych więcej niż co czwartemu z respondentów przypisano najwyższą wartość wskaźnika, podczas gdy tylko nielicznych (5\% ogółu) cechowała jego wartość najniższa [tabela 46]. 
Tabela 46. Składowe komponentu sieci - poczucie wpływu na funkcjonowanie LGD

\begin{tabular}{|l|c|c|c|c|c|c|}
\hline \multirow{2}{*}{$\begin{array}{l}\text { Poczucie wpływu na funkcjo- } \\
\text { nowanie LGD }\left(\mathrm{S}_{3}\right) \mathrm{N}=450\end{array}$} & \multicolumn{2}{|c|}{$\mathrm{S}_{3}=2$} & \multicolumn{2}{c|}{$\mathrm{S}_{3}=1$} & \multicolumn{2}{c|}{$\mathrm{S}_{3}=0$} \\
\cline { 2 - 8 } & liczba & odsetek & liczba & odsetek & liczba & odsetek \\
\cline { 2 - 8 } & 124 & 27,6 & 304 & 67,6 & 22 & 4,9 \\
\hline
\end{tabular}

Źródło: opracowanie własne.

Rezultatem zsumowania uzyskanych wartości wszystkich zmiennych składowych komponentu sieci był zbiorczy wskaźnik komponentu, obrazujący jego poziom w badanych organizacjach. Osiągnął on w analizowanej grupie średnią wartość 3,53 punktu (w standaryzowanej siedmiopunktowej skali obejmującej zakres od 0 do 6 punktów), przy czym tylko 4\% respondentów uzyskało jego najniższe wartości (oznaczające małe zaangażowanie we współpracę na rzecz partnerstwa/gminy lub jego brak, niski poziom aktywności w LGD oraz partycypacji w decyzjach dotyczących jej funkcjonowania, a także poczucie ograniczonego wpływu działań LGD na procesy społeczno-gospodarcze zachodzące na obszarze partnerstwa), zaś co piąty uzyskał jego wartości najwyższe (związane z wysokim poziomem wskazanych zmiennych cząstkowych - por. wykres 3 ).

Wykres 3. Poziom komponentu sieci w badanych LGD

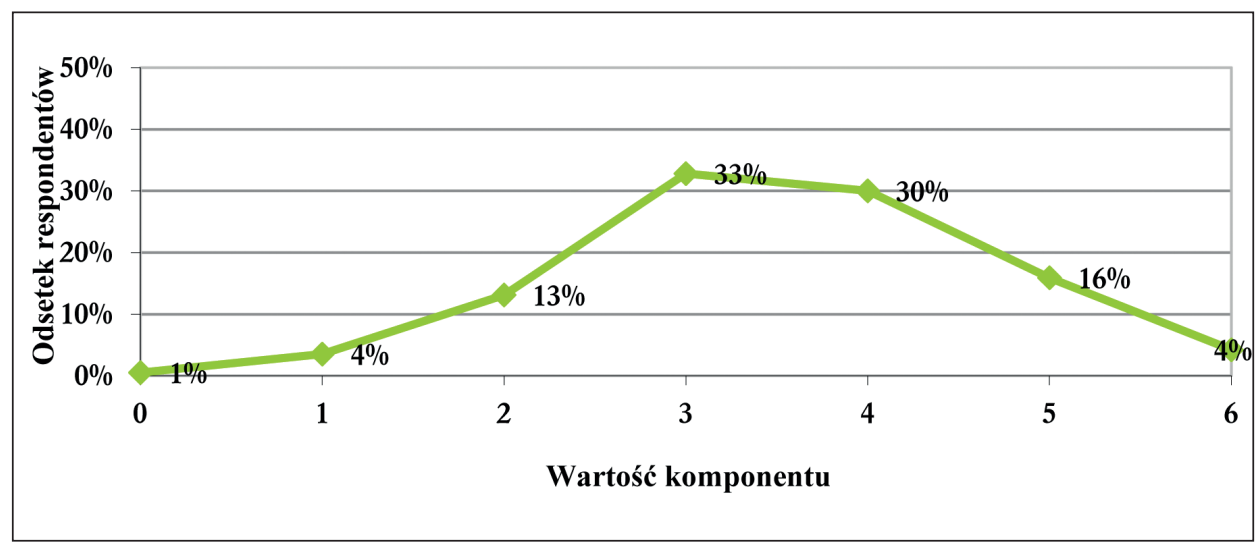

Źródło: opracowanie własne.

Wszystkie opisane pytania wskaźnikowe, pozwalające na oszacowanie wartości poszczególnych komponentów, potraktowano jako równie istotne (mające taką samą wagę) i włączono do indeksu kapitału społecznego. Sumując je uzyskano wartości liczbowe wyrażające w syntetycznej formie najpierw poziom każdego z komponentów (co zaprezentowano powyżej), a docelowo także poziom kapitału społecznego lokalnych grup działania. 


\subsection{Struktura i poziom kapitału społecznego LGD z wybranych województw - konkluzje}

W wyniku zastosowania opisanych procedur metodologicznych otrzymano syntetyczną skalę kapitału społecznego o potencjalnej rozpiętości 19 punktów. Okazało się jednak, że sześć teoretycznie możliwych najniższych wartości skali nie wystąpiło empirycznie (por. wykres 4). W związku z tym (zauważając, że generalnie poziom analizowanej zmiennej w badanej grupie jest wysoki), oszacowania i interpretacji poziomu kapitału społecznego członków lokalnych grup działania jako bardzo wysokiego, wysokiego, przeciętnego, niskiego lub bardzo niskiego dokonywano w odniesieniu do jego wartości średniej, która wyniosła w badanej zbiorowości 11,95 punktu.

Wykres 4. Poziom kapitału społecznego w badanych LGD (suma komponentów)

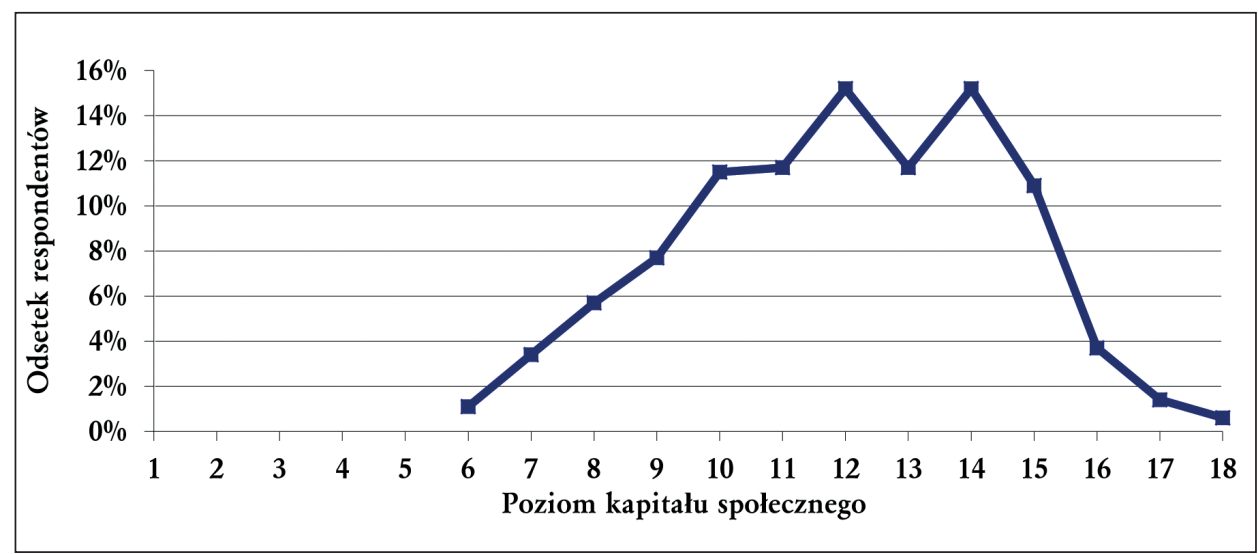

Źródło: opracowanie własne.

Niemal 40\% badanych charakteryzowało się przeciętnym poziomem analizowanej zmiennej, co trzeciemu przypisano jego ponadprzeciętną wartość, pozostałym 30\% respondentów odpowiadały wartości poniżej przeciętnej (bardzo wysokim poziomem kapitału społecznego charakteryzowało się niespełna $6 \%$ badanych, bardzo niskim nieco ponad 10\% ich ogółu).

Wysokie wartości syntetycznej zmiennej kapitału społecznego odnotowano przede wszystkim wśród osób reprezentujących kadry kierownicze - kategorii zawodowej wiążącej się z wyższą pozycją społeczną mierzoną wyższym prestiżem i wyższymi dochodami. Wśród osób z wykształceniem wyższym (wysokie wartości zmiennej przypisano 40\% respondentów z tej kategorii, podczas gdy w pozostałych kategoriach odsetek ten był niższy o co najmniej 20 punktów procentowych); wśród mężczyzn ponadprzeciętna wartość zmiennej charakteryzowała ponad 39\% kategorii, podczas gdy wśród kobiet odsetek ten wyniósł 22,3. 
Wysokie wartości zmiennej kapitału społecznego odnotowano także u większego odsetka osób powyżej 44. roku życia (osiągnęło je 40\% należących do tej kategorii), niż miało to miejsce w przypadku osób młodszych (20\% kategorii). A zatem, w lokalnych grupach działania mamy wprawdzie do czynienia ze stosunkowo wysokim poziomem kapitału społecznego, ale jego nośnikami nie są w jednakowym stopniu wszyscy członkowie grup. Wydaje się, że w odniesieniu do badanej zbiorowości uzasadniona jest teza, że stosunkowo wysoki poziom jej kapitału społecznego, przynajmniej częściowo, warunkują charakterystyki społeczno-demograficzne jej członków (poziom kapitału ludzkiego).

Obliguje to do dużej ostrożności zarówno w dokonywaniu interpretacji uzyskanych rezultatów, jak i przede wszystkim w formułowaniu hipotez wykraczających poza badaną zbiorowość, ponieważ, jak pokazano we wcześniejszych rozdziałach, mamy w niej do czynienia ze swoistą nadreprezentacją osób o wysokim poziomie kapitału ludzkiego (por. rozdział II). Sytuacja ta, podobnie jak opisane w pierwszym rozdziale problemy z realizacją badania według przyjętych założeń, nie zwalnia jednak z podjęcia próby zweryfikowania hipotez stanowiących punkt wyjścia przeprowadzonych badań.

Przystępując do analiz kapitału społecznego lokalnych grup działania, postawiono m.in. dwie hipotezy dotyczące jego struktury i poziomu poszczególnych składowych. Przypuszczano, że:

1. Kapitał społeczny lokalnych grup działania posiada cechy kapitału zdekomponowanego, tj. między wszystkimi komponentami tego kapitału nie będą występowały zależności istotne statystycznie.

2. W strukturze kapitału społecznego lokalnych grup działania najniższym poziomem cechuje się komponent sieci.

Uzyskane wyniki i przeprowadzone analizy zdają się co najmniej częściowo potwierdzać obydwa przypuszczenia ${ }^{20}$. Odnosząc się do pierwszego z nich, należy zauważyć, że wprawdzie między wyróżnionymi komponentami kapitału społecznego zaobserwowano związki, ale w żadnym przypadku nie były one zbyt silne [por. tabela 47].

Tabela 47. Związek między komponentami kapitału społecznego

\begin{tabular}{|l|c|c|c|}
\hline \multicolumn{1}{|c|}{ Komponenty } & Komponent sieci & $\begin{array}{c}\text { Komponent norm } \\
\text { i wartości }\end{array}$ & Komponent zaufania \\
\hline Komponent sieci & & $0,31^{* *}$ & $0,23^{* *}$ \\
\hline Komponent norm i wartości & $0,31^{* *}$ & & $0,29^{* *}$ \\
\hline Komponent zaufania & $0,23^{* *}$ & $0,29^{* *}$ & \\
\hline
\end{tabular}

Współczynniki korelacji $r$ Pearsona ${ }^{* *} \mathrm{p}=0,01$, test dwustronny.

Źródło: opracowanie własne.

${ }^{20}$ Ze względu na charakter doboru próby, wnioski mają odniesienie tylko do zbiorowości, która wzięła udział w badaniu. 
Stosunkowo najsilniejszą zależność $(r=0,31)$ zaobserwowano pomiędzy komponentem norm i wartości oraz komponentem sieci, ale zważywszy na konstrukcję obu tych zmiennych, trudno uznać tę zależność za znaczącą. Jako elementy składowe obu komponentów włączono zjawiska związane bezpośrednio z działalnością respondentów w LGD, potencjalnie wzajemnie się warunkujące. W ramach komponentu norm i wartości były to motywacje uczestnictwa w LGD (chęć reprezentowania interesów partnerstwa) oraz przekonania dotyczące potrzeby współpracy na rzecz partnerstwa. W ramach komponentu sieci odpowiadać im miała (przynajmniej według przyjętych założeń) określona aktywność w pracach lokalnej grupy (działanie na rzecz interesów partnerstwa). A zatem zaobserwowany słaby związek między komponentami oznacza także słaby związek między deklaracjami respondentów dotyczącymi motywów i wartości kierujących ich postępowaniem a faktycznie realizowanymi działaniami (związanymi nie tylko z samym uczestnictwem $w$ organizacji). $Z$ pewnością nie świadczy to o spójności i sile ich kapitału społecznego.

Co ciekawe, a jednocześnie dodatkowo przemawiające za konfirmacją postawionej hipotezy, najsłabiej powiązany z pozostałymi elementami kapitału społecznego okazał się komponent zaufania (w ramach którego umieszczono m.in. zaufanie do współpracowników z LGD, a także zaufanie do rozmaitych lokalnych instytucji, z którymi i/lub w ramach których badani także współpracują bądź współpracowali w przeszłości). W praktyce oznacza to nie tylko niską skłonność do zawierania nowych kontaktów i tworzenia nowych sieci (zaufaniem obdarzani są tylko najbliżsi współpracownicy, przede wszystkim z własnego sektora), lecz także świadczy o kruchości podstaw aktualnej współpracy w ramach LGD. Jak już wcześniej sygnalizowano, rzeczywista współpraca odbywa się często w ramach wąskiego i stosunkowo zamkniętego kręgu osób sprawujących (długookresowo) najwyższe funkcje w organach decyzyjnych grupy.

Za przedstawioną interpretacją (przy okazji potwierdzając drugą z weryfikowanych w niniejszym rozdziale hipotez) przemawiają także dane, dotyczące poziomu poszczególnych komponentów, omówione szczegółowo w drugiej części niniejszego rozdziału. Przypomnieć warto, że w badanej zbiorowości stosunkowo najwyższym poziomem cechuje się komponent norm i wartości - ponad $60 \%$ badanych przypisało ponadprzeciętną wartość tej zmiennej, podczas gdy w przypadku komponentu zaufania analogiczna sytuacja dotyczyła $33 \%$ badanych (w przypadku komponentu sieci ponadprzeciętną jego wartość zaobserwowano u $20 \%$ badanych). Najniższą średnią wartość w badanej grupie (3,53 punktu w siedmiostopniowej skali od 0 do 6 punktów) uzyskał komponent sieci (związany z realizacją praktycznych działań, rzeczywistym funkcjonowaniem w relacjach z innymi osobami i instytucjami), a najwyższą (4,73 punktu) - komponent norm i wartości (związany głównie ze sferą deklaracji i przekonań na własny temat).

Wzajemny układ wszystkich komponentów zaprezentowano na wykresie 5. 
Wykres 5. Poziom komponentów kapitału społecznego badanych LGD

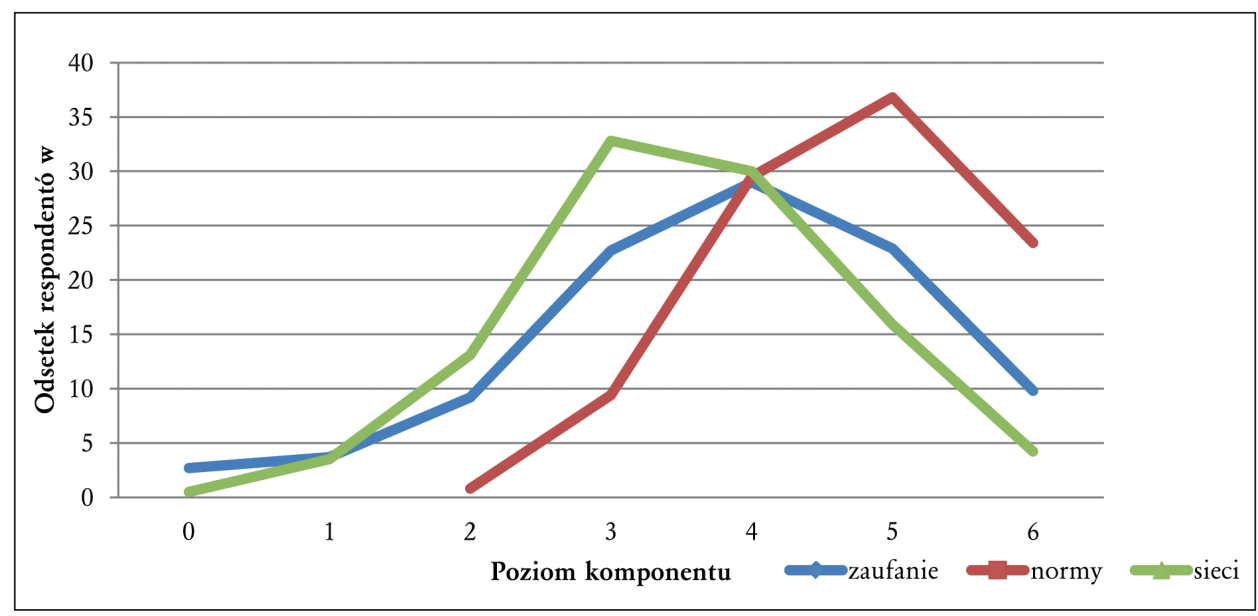

Źródło: opracowanie własne.

Przeprowadzone analizy, choć nie uprawniają do wnioskowania o specyfice kapitału społecznego wszystkich polskich LGD, wskazują na problemy dotyczące ich znaczącej części (badania przeprowadzono w 6 województwach). Są związane głównie z charakterem współpracy członków tych struktur. Ponieważ w próbie znaleźli się (w przeważającej części) najaktywniejsi z nich, zastanawia relatywnie niski poziom partycypacji w działaniach LGD tych badanych, którzy nie sprawują w nich funkcji zarządczych, kontrolnych czy doradczych. Lokalne grupy działania są strukturami w wysokim stopniu sprofesjonalizowanymi, zhierarchizowanymi i poddanymi procesowi ekonomizacji. Mimo że ich forma prawna (fundacje, stowarzyszenia, związki stowarzyszeń) mogła stanowić przesłankę do traktowania ich jako podmiotów, których funkcjonowanie może (w sposób szczególny) wspierać budowę społeczeństwa obywatelskiego, okazuje się, że bliżej im do nowych form agencji rozwoju regionalnego niż do organizacji, które starają się włączać w swoje działania jak największą liczbą członków (o powodach i konsekwencjach tego stanu rzeczy szerzej traktuje ostatnia część niniejszej pracy). Zaobserwowany słaby związek (lub wręcz jego brak) między wyróżnionymi komponentami kapitału społecznego pozwala dostrzec problemy związane z aktywizowaniem wiejskich i małomiasteczkowych społeczności lokalnych. Wsparcie związane z tworzeniem nowych sieci współpracy może nie skutkować wzrostem poziomu zaufania członków tych społeczności (zwłaszcza zaufania zgeneralizowanego). Sposób organizacji struktury badanych LGD (w różnym zakresie) może wręcz wykluczać (czy zmniejszać szanse) partycypacji w procesach decyzyjnych samych jej członków (stawiając pod znakiem zapytania realizację niektórych zasad podejścia LEADER - zasady partnerstwa oraz oddolnego podejścia). 
ROZDZIAŁ IV

\section{UWARUNKOWANIA KAPITAŁU SPOŁECZNEGO LGD REPREZENTUJĄCYCH WOJEWÓDZTWA, NA TERENIE KTÓRYCH FUNKCJONUJĄ NAJWIĘKSZE I NAJMNIEJSZE SIECI TEGO TYPU ORGANIZACJI}

Przedstawione powyżej analizy pozwoliły scharakteryzować strukturę i oszacować poziom kapitału społecznego lokalnych grup działania z terenu sześciu województw. Niniejszy rozdział stanowi próbę wskazania i opisu wybranych czynników wpływających na kształt i poziom uzyskanych charakterystyk oraz ich porównania $w$ grupach działających na obszarach, na terenie których funkcjonuje najwięcej i najmniej sieci tego typu organizacji.

W ramach konceptualizacji projektu badawczego stanowiącego podstawę niniejszej publikacji sformułowano trzy hipotez badawcze dotyczące społeczno-ekonomicznych uwarunkowań poziomu kapitału społecznego lokalnych grup działania. Przypuszczano, że:

1. im wyższy będzie poziom aktywności społecznej na obszarze, na rzecz którego funkcjonują lokalne grupy działania ${ }^{1}$, tym wyższy będzie także poziom ich kapitału społecznego;

2. im niższy będzie poziom gospodarczego rozwoju obszaru, na rzecz którego funkcjonują lokalne grupy działania, tym niższy okaże się poziom ich kapitału społecznego;

3. im wyższy poziom współpracy między sektorem społecznym, publicznym i gospodarczym zostanie odnotowany na obszarze, na rzecz którego funkcjonują lokalne grupy działania, tym wyższy będzie poziom ich kapitału społecznego.

Kolejne części książki poświęcono weryfikacji poszczególnych hipotez. Szczegółowym analizom poddano wszystkie lokalne grupy działania $\mathrm{z}$ województwa opolskiego, lubuskiego i zachodniopomorskiego oraz losowo wybrane

${ }^{1}$ Założono, że świadczyć o nim będzie między innymi wielkość sieci lokalnych grup działania działających na badanym obszarze. 
z Małopolski, Wielkopolski i Podkarpacia ${ }^{2}$. Podstawę prowadzonych poniżej analiz stanowią zatem dane dotyczące 18 LGD (dziewięciu z województw, na terenie których działa najwięcej organizacji tego typu oraz dziewięciu z województw o najmniejszej ich liczbie).

Weryfikację hipotez poprzedzono podrozdziałem uzupełniającym wizerunek wybranych LGD z obu analizowanych zbiorów o charakterystyki społeczno-demograficzne ich członków (zwłaszcza ich potencjalnych liderów - przedstawicieli zarządu i rady). Analizie poddano w nim także aktywność grup w zakresie wdrażania projektów współpracy, finansowanych ze środków PROW 2007-2013 oraz realizacji projektów finansowanych z funduszy innych niż Program Rozwoju Obszarów Wiejskich 2007-20134.

\subsection{Charakterystyki społeczno-demograficzne członków wybranych LGD oraz aktywność grup w zakresie realizacji projektów}

Geneza większości LGD z obu porównywanych zbiorów wiąże się z wdrażaniem Pilotażowego Programu LEADER +. Niemal 88\% badanych członków organizacji należących do pierwszego zbioru (LGD reprezentujących województwa, na terenie których funkcjonuje najmniejsza liczba struktur tego typu) opisuje ich powstanie jako skutek realizacji wspomnianego programu, podczas gdy analogiczną genezę swoim organizacjom przypisuje aż 94\% członków lokalnych grup działania, reprezentujących drugi z wyróżnionych zbiorów (organizacje reprezentujące województwa, na terenie których funkcjonuje największa liczba LGD) ${ }^{5}$. Jednocześnie proporcje liczby członków, których staż w organizacji sięga wdrażania Pilotażowego Programu LEADER+ (czyli co najmniej roku 2008) i liczby członków, którzy przyłączyli się do grupy w późniejszym okresie są niemal identyczne w analizowanych LGD z obu wyróżnionych zbiorów. W obu typach grup niespełna $60 \%$ stanowią członkowie z co najmniej czteroletnim stażem (sięgającym realizacji PP LEADER+), zaś nieco ponad 40\% - członkowie ze stażem

${ }^{2}$ Dla przypomnienia były to: Ostrzeszowska LGD oraz KOLD z Wielkopolski, Dunajec-Biała, PROKOPARA i Dolina Karpia z Małopolski oraz Subregion Magurski, Lasovia, CK Podkarpacie, Partnerstwo dla Ziemi Niżańskiej z Podkarpacia.

${ }^{3}$ Wykaz wszystkich projektów znajduje się w Aneksie w załączniku 6.

${ }^{4} \mathrm{~W}$ analizie uwzględniono projekty finansowane ze środków innych niż PROW 2007-2013 (to jest m.in. z PO KL, FIO, Akademii Rozwoju Filantropii) oraz o projektach współpracy wyszczególnionych na stronach internetowych lokalnych grup działania. Informację na ich temat pozyskiwano również od kierowników biur.

${ }^{5}$ Obszerne rekonstrukcje genezy wszystkich grup objętych badaniem szczegółowym zamieszczono w poprzedniej części pracy (patrz rozdział 1.2.3). 
krótszym. Warto zauważyć, iż niezależnie od zbioru staż pracy w LGD wiąże się bezpośrednio $\mathrm{z}$ wiekiem badanych. W całej analizowanej zbiorowości wśród osób najmłodszych (poniżej 35 roku życia) niespełna co trzecia (31\% kategorii) deklaruje przynależność do LGD w okresie wdrażania Pilotażowego Programu LEADER+, wśród osób w wieku 35-54 lata deklarację taką składa co druga z nich, zaś wśród osób najstarszych (powyżej 54. roku życia) - trzy czwarte z nich.

Analizując wiek członków LGD z obu zbiorów poddanych analizie, należy zauważyć, iż struktura obu grup ze względu na tę zmienną jest bardzo podobna. W obu zbiorach dominującą kategorię stanowią osoby w wieku od 45 do 64 lat, przy czym w zbiorze I znajduje się w niej nieco więcej osób, które nie przekroczyły 55. roku życia, co zaprezentowano na wykresie 6.

Wykres 6. Wiek członków LGD należących do obu zbiorów

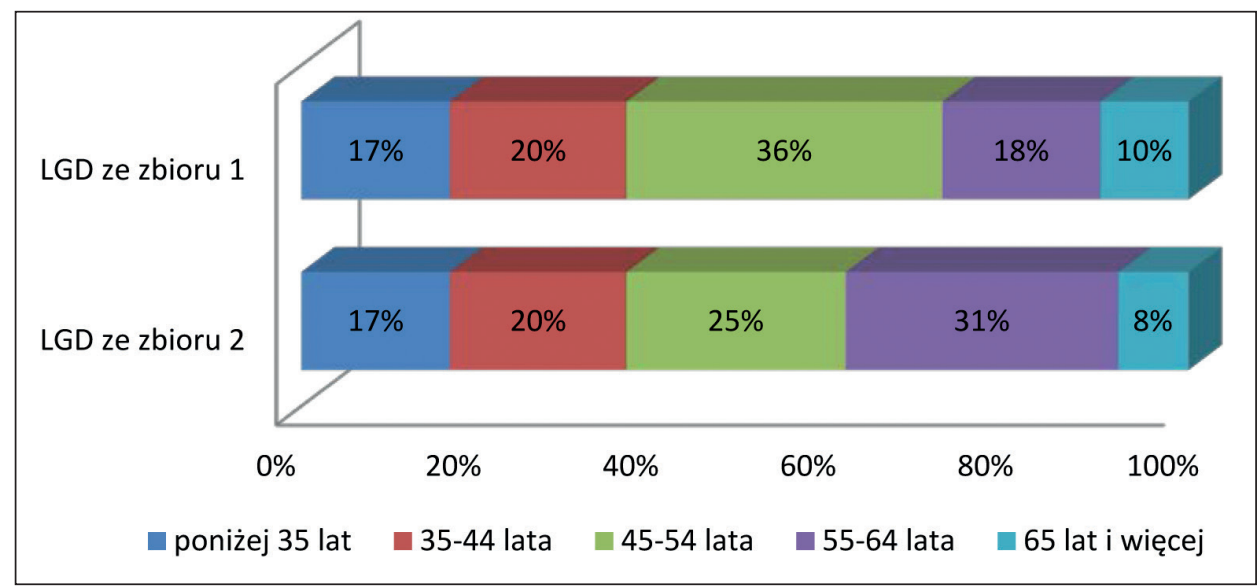

Źródło: opracowanie własne.

Cechą różnicującą oba zbiory okazała się płeć członków LGD. Wśród badanych z lokalnych grup działania należących do pierwszego zbioru znalazł się znacząco mniejszy odsetek kobiet (36\% badanego składu grupy), niż miało to miejsce w grupach należących do zbioru drugiego (gdzie kobiety stanowiły $47 \%$ ogółu badanych).

Widoczną różnicę odnotowano także w proporcjach osób pracujących i niepracujących, uczestniczących w pracach obu badanych grup. Wśród ankietowa-

${ }^{6}$ Drobna różnica między zbiorami, nie powodująca zmiany ogólnej tendencji, dotyczy deklaracji osób najmłodszych i najstarszych. Wśród badanych z I zbioru co czwarty liczący do 34 lat należał do LGD w okresie wdrażania PP Leader+, podczas gdy w II zbiorze staż taki posiadał więcej niż co trzeci przedstawiciel tej kategorii wiekowej. Z kolei wśród osób należących do kategorii wiekowej powyżej 54 lat - w zbiorze I znalazło się $81 \%$ osób deklarujących przynależność do organizacji obejmującą wdrażanie PP Leader+, zaś w zbiorze II odsetek takich osób wyniósł 70\% kategorii. 
nych członków LGD z pierwszego zbioru było $83 \%$ osób pracujących, podczas gdy wśród członków LGD z drugiego zbioru odsetek ten wyniósł $76 \%$ składu grupy. Jednocześnie wśród niepracujących z pierwszego zbioru tylko co ósmy był osobą bezrobotną ( 2 osoby z 16 badanych z tej kategorii), zaś wśród osób niepracujących reprezentujących LGD ze zbioru drugiego bezrobotna była co piąta osoba ( 8 z 39 badanych należących do tej kategorii). Charakteryzując sytuację zawodową badanych należących do porównywanych grup warto także odnotować, iż wśród respondentów reprezentujących organizacje z pierwszego zbioru $93 \%$ stanowiły osoby pracujące poza rolnictwem, zaś wśród badanych reprezentujących zbiór drugi odsetek takich osób był nieco mniejszy i wyniósł 86\% ogółu grupy.

Bardzo podobnie prezentowała się za to struktura grup ze względu na przynależność ich członków do różnych kategorii społeczno-zawodowych. Największe odsetki członków organizacji z obu zbiorów reprezentowały kategorie specjalistów zajmujących stanowiska kierownicze ( $45 \%$ badanych ze zbioru I i $38 \%$ badanych ze zbioru II) oraz pracowników umysłowych: biurowo-administracyjnych oraz sektora handlu i usług (36\% badanych ze zbioru I i 39\% badanych ze zbioru II). Pozostałe kategorie społeczno-zawodowe reprezentowane były tylko przez niewielkie, nieprzekraczające $10 \%$ odsetki członków LGD z obu zbiorów [por. wykres 7].

Wykres 7. Kategorie zawodowe członków LGD

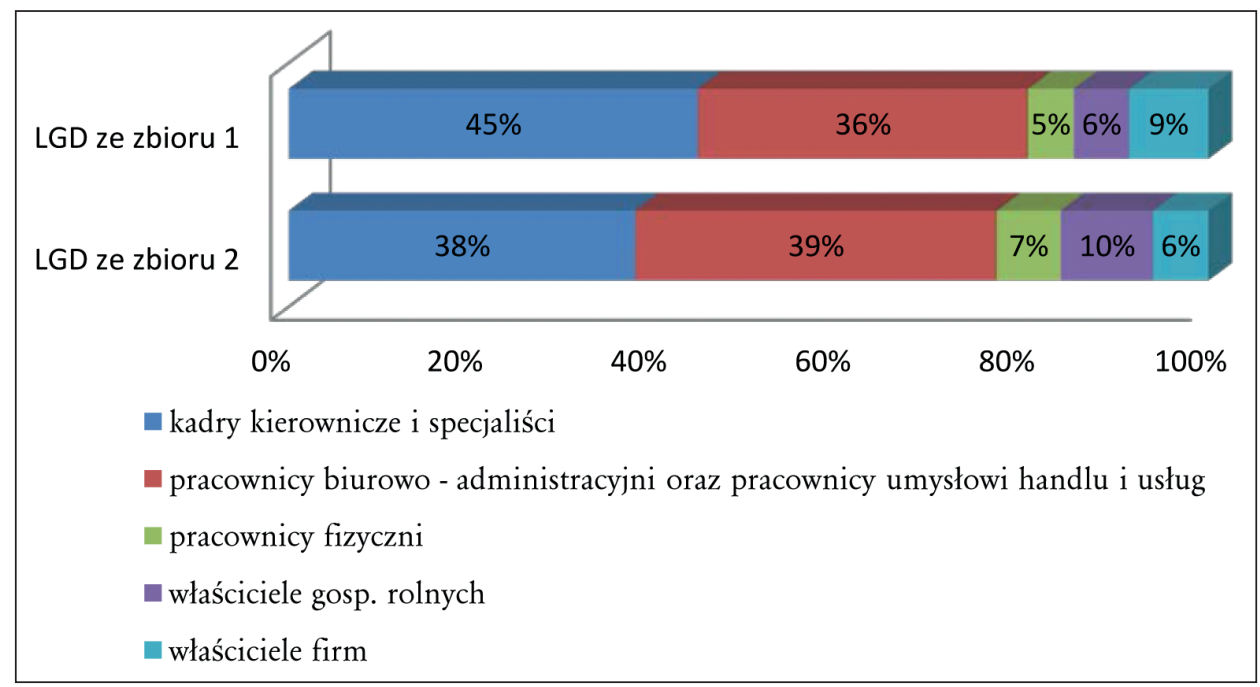

Źródło: opracowanie własne.

Zaprezentowana przynależność respondentów do określonych kategorii zawodowych niewątpliwie wiązała się z ich wykształceniem. W obu porównywanych grupach kategorię najliczniejszą stanowiły osoby z wykształceniem wyższym, przy czym należy zwrócić uwagę na istotną różnicę proporcji tej kategorii 
w ramach każdego z porównywanych zbiorów grup. Wśród badanych reprezentujących lokalne grupy działania z pierwszego zbioru osoby legitymujące się wykształceniem wyższym stanowiły aż $68 \%$ ogółu, podczas gdy wśród reprezentantów zbioru drugiego odsetek osób, które zdobyły wykształcenie wyższe wyniósł $46 \%$ ogółu. Jednocześnie w zbiorze drugim znalazł się większy, niż miało to miejsce w przypadku zbioru pierwszego, odsetek osób posiadających wykształcenie niższe od średniego (odpowiednio 17 i 9\% składu zbioru).

Wykres 8. Wykształcenie członków porównywanych LGD

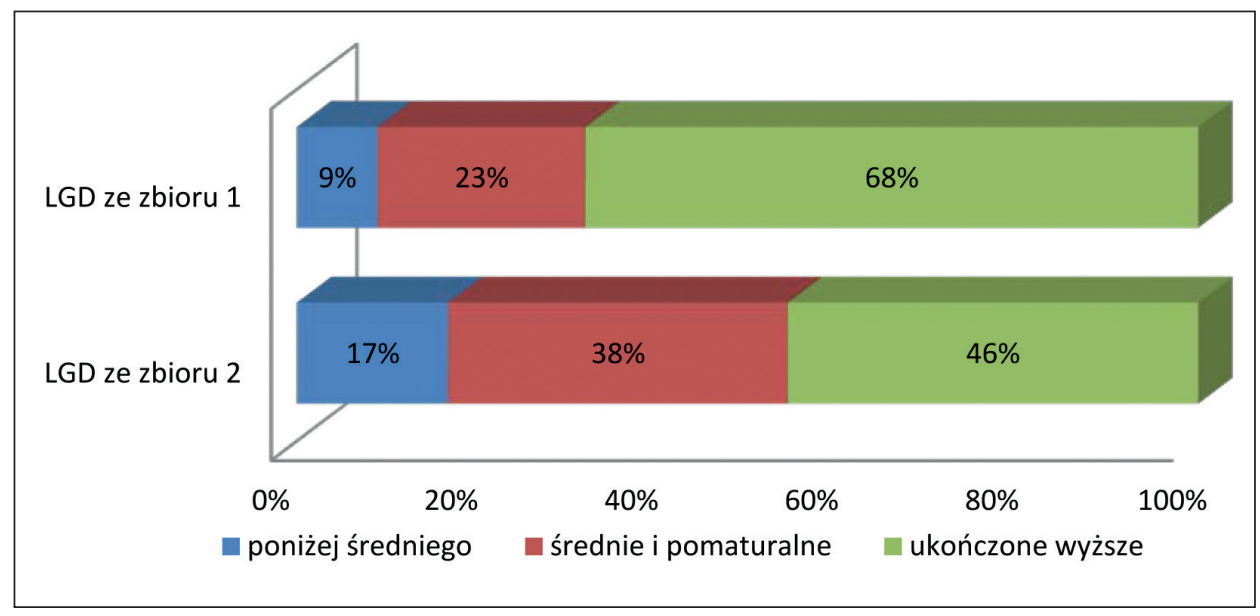

Źródło: opracowanie własne.

Organizacje reprezentujące województwa o największej sieci lokalnych grup działania (zbiór II) oraz grupy reprezentujące województwa o najmniejszej sieci struktur tego typu (zbiór I) nie różnily się między sobą ze względu na proporcje reprezentantów poszczególnych sektorów działających w ich ramach. Dominującą kategorię w obu typach województw stanowili przedstawiciele sektora społecznego (odpowiednio 51 i 50\% grupy), zaś kategorię najmniej liczną przedstawiciele sektora gospodarczego (16 i 19\%). Przedstawiciele sektora publicznego stanowili niemal jedną trzecią (33 i 32\%) składu każdej z grup. Istotnych różnic nie zaobserwowano także w kwestii ,zakorzenienia” członków lokalnych grup działania w lokalnych społecznościach. $65 \%$ członków LGD ze zbioru pierwszego i $69 \%$ członków LGD ze zbioru drugiego urodziło się w gminie objętej oddziaływaniem organizacji.

Widoczne różnice między porównywanymi zbiorami pojawiły się natomiast przy analizie składu grup ze względu na funkcje pełnione przez ich członków. Lokalne grupy działania ze zbioru pierwszego były reprezentowane przez znacząco mniejszą w stosunku do zbioru drugiego grupę członków zwyczajnych tych organizacji (odpowiednio 38 i 53\% zbioru). Tym samym wśród reprezentantów tych 
grup znalazło się więcej osób należących do ich organów decyzyjnych. Członkowie rad i zarządów LGD stanowili 57\% składu pierwszego zbioru i 43\% składu zbioru drugiego [por. wykres 9].

Wykres 9. Skład LGD ze względu na pełnione funkcje

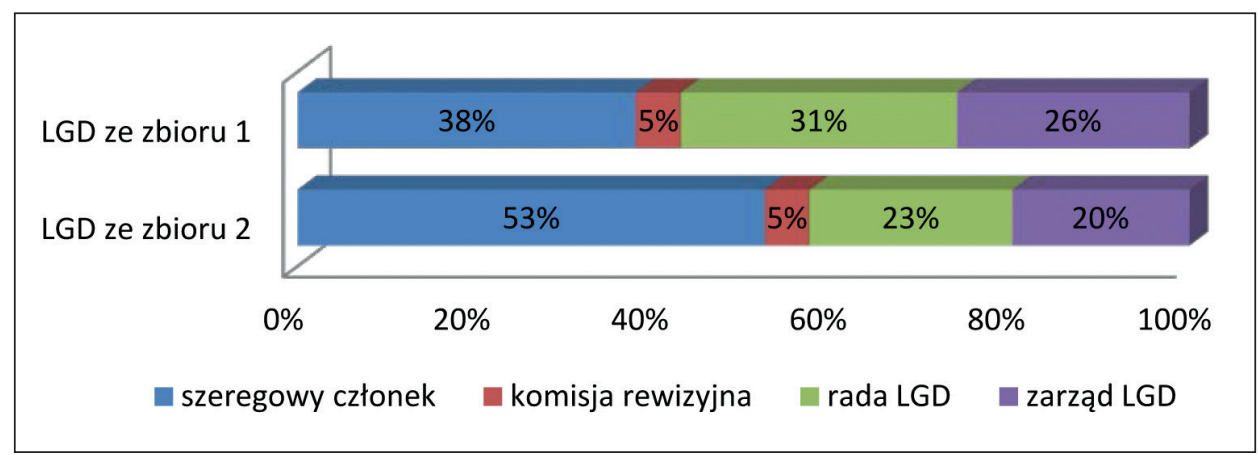

Źródło: opracowanie własne.

Tabela 48. Charakterystyki społeczno-demograficzne władz LGD (w \%)

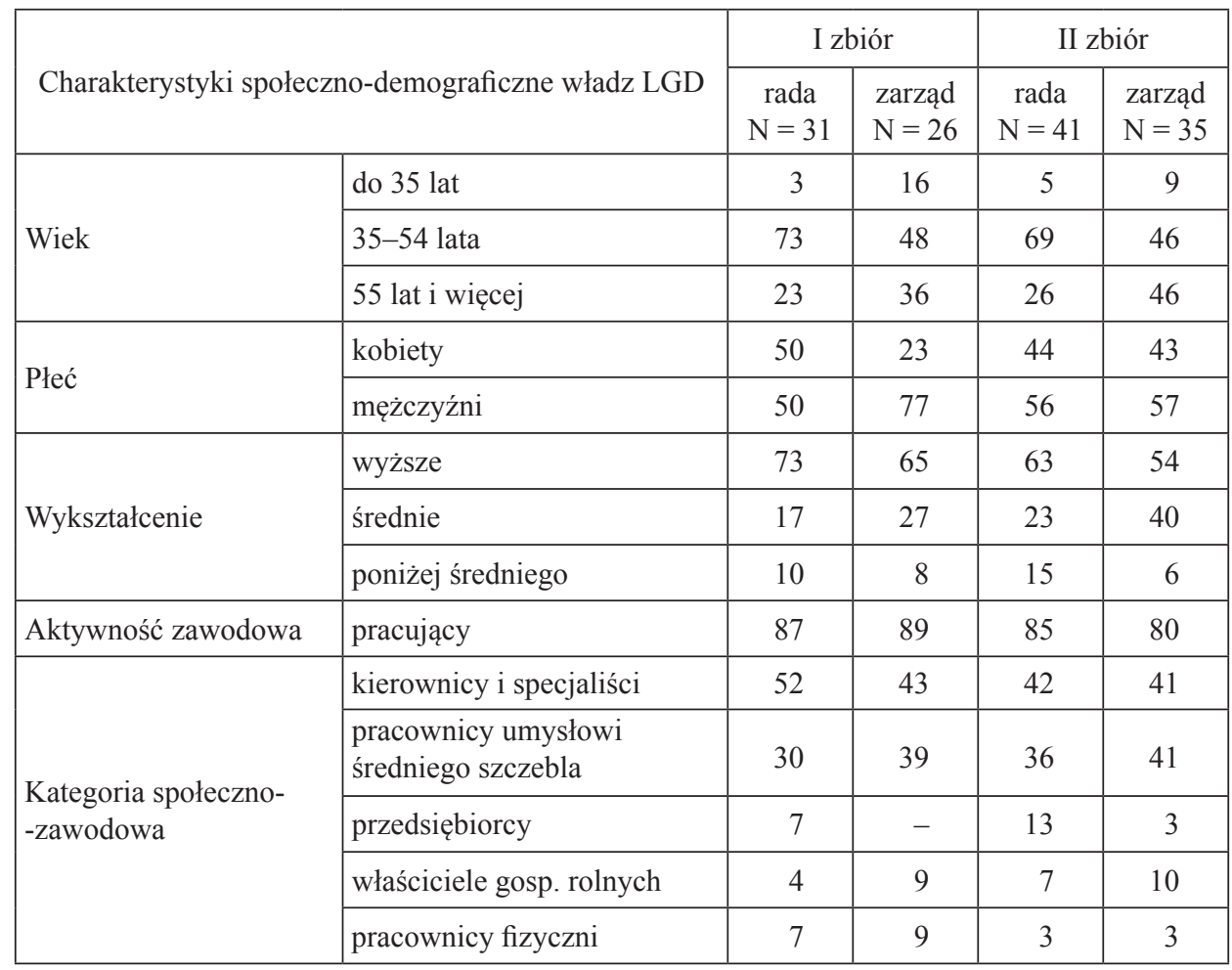

Źródło: opracowanie własne. 
Niezależnie od zbioru, z którego się rekrutowali, członkowie rad i zarządów LGD to przede wszystkim osoby w wieku 35-45 lat posiadające wyższe wykształcenie i wysoką pozycję zawodową (przy czym osób o takich charakterystykach jest relatywnie więcej w radach niż w zarządach), częściej mężczyźni niż kobiety (zwłaszcza w zarządach - por. tabela 48). W przypadku obu typów grup w ich władzach zasiadają zatem osoby dysponujące już wcześniej stosunkowo wysokimi (w odniesieniu do pozostałych członków organizacji) zasobami (kapitałem ludzkim i prawdopodobnie także ekonomicznym).

Warto zauważyć, że w przypadku LGD z obu typów województw rady zrzeszały więcej członków niż zarządy. Większa liczba osób w tych organach nie pozostawała jednak w związku z liczbą realizowanych projektów. Nie jest ona zatem wskaźnikiem aktywności członków zwyczajnych tych organizacji, ani aktywności wszystkich członków zarządu i rady. Może jedynie świadczyć o działalności podejmowanej przez ich liderów, rekrutujących się najczęściej z tych organów lub spośród pracowników biur.

Liczebność zarządów i rad LGD oraz liczbę realizowanych przez nie projektów z obu źródeł zaprezentowano na wykresie 10.

Wykres 10. Liczba członków zarządu i rady LGD oraz liczba zrealizowanych projektów

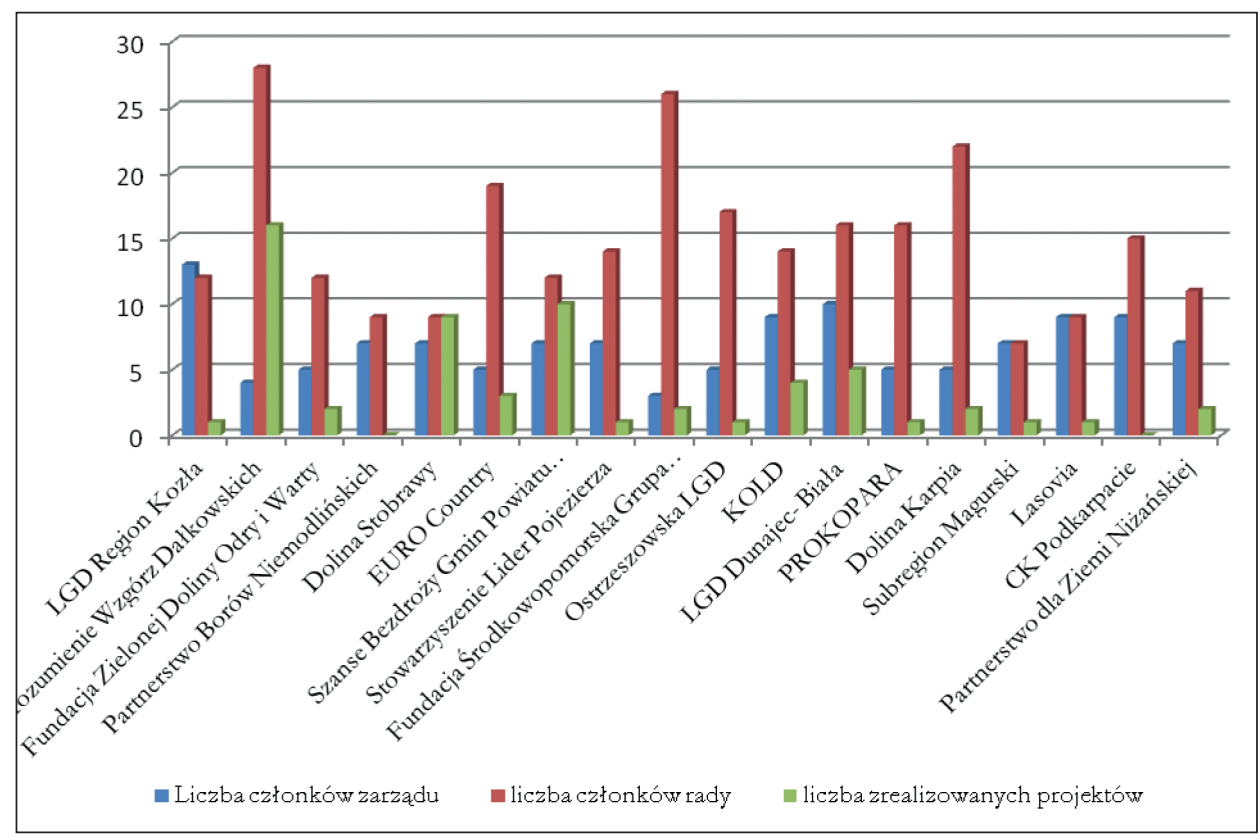

Źródło: opracowanie własne.

Największą aktywność w zakresie pozyskiwania środków na analizowane projekty wykazały LGD z pierwszego zbioru. W sumie organizacje z lubuskiego 
zrealizowały 19 projektów, z opolskiego 12, z zachodniopomorskiego 13. Aktywność LGD $\mathrm{z}$ drugiego zbioru $\mathrm{w}$ tym zakresie była zdecydowanie niższa. Stowarzyszenia z Wielkopolski wdrażają w sumie 5 projektów, z Małopolski 8, z Podkarpacia 4.

Jeśli liczbę tych projektów potraktować jako wskaźnik aktywności ich liderów, to okazuje się, że LGD z województw, którym przypisuje się niższy poziom kapitału społecznego ich mieszkańców działają efektywniej w zakresie pozyskiwania zewnętrznych środków na realizację celów statutowych, w tym na projekty współpracy.

Wykres 11. Projekty realizowane przez LGD

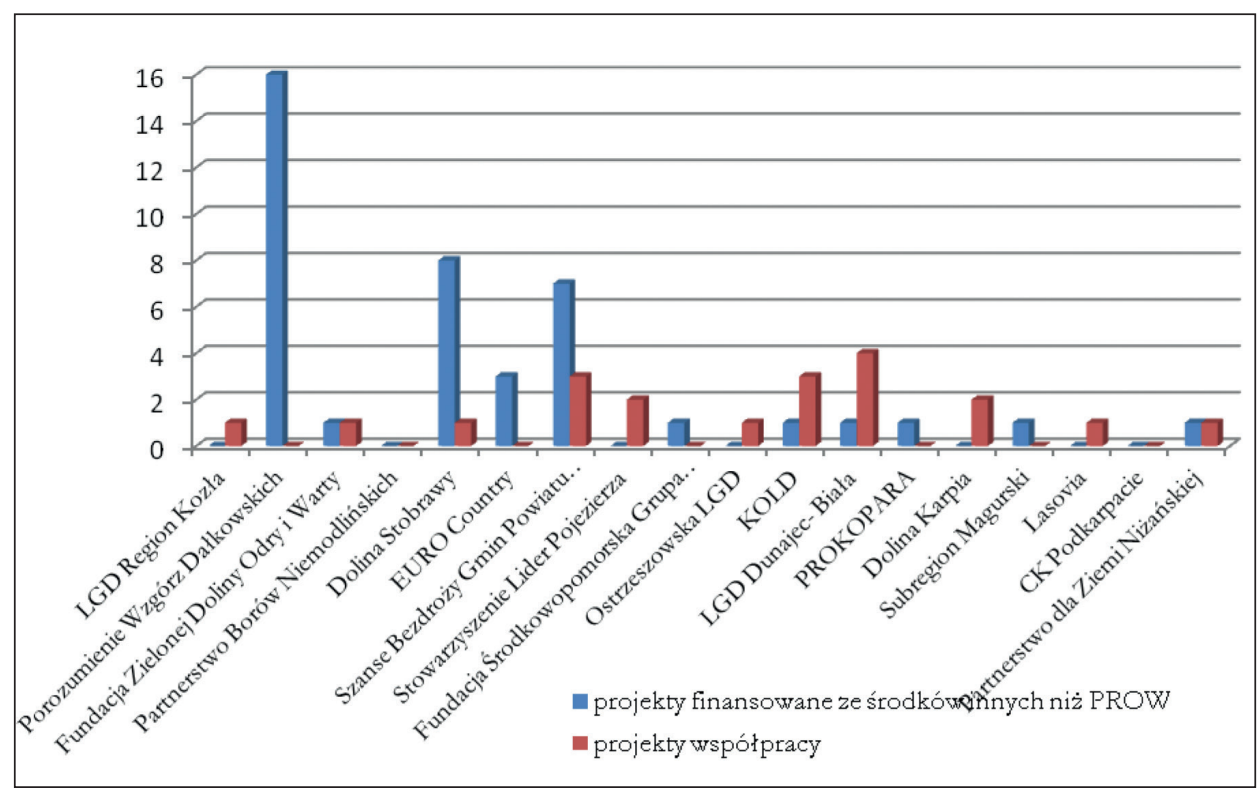

Źródło: opracowanie własne.

Projekty współpracy mogą mieć wymiar regionalny (LGD z tego samego województwa realizują wspólny cel), międzyregionalny i międzynarodowy. Każdy z nich może świadczyć o aktywności tych organizacji. Nawet jeśli jest ona pochodną działań nielicznej zborowości liderów, to i tak pozwala wnioskować o potencjale ich współpracy oraz kondycji elementów sieci w największym stopniu odpowiedzialnych za podejmowane przez nie działania.

Nie wszystkie z badanych LGD realizowały takie projekty. Organizacje z pierwszego typu województw zrealizowały (realizują) ich 8, z drugiego 11 . W zdecydowanej większości są to projekty współpracy regionalnej i międzyregionalnej (współpracują w nich LGD z tego samego województwa lub z województw ościennych). W pierwszym zbiorze tylko jedna organizacja realizuje projekt z partnerami zagranicznymi, w drugim jest ich 6 . 
A zatem analiza liczby realizowanych projektów LGD usytuowanych na obszarze dwóch typów województw wykazuje, iż co prawda bardziej aktywne są tu organizacje $\mathrm{z}$ pierwszego $\mathrm{z}$ nich, jednak to grupy $\mathrm{z}$ drugiego realizują większą liczbę projektów współpracy. Trudno ocenić, które z nich świadczą o większym zaangażowaniu liderów lokalnych w funkcjonowanie LGD. Równie trudne może być nawiązanie współpracy z partnerami zagranicznymi i z osobami długotrwale bezrobotnymi (beneficjentami ostatecznymi projektów aktywizacji zawodowej).

\subsection{Struktura kapitału społecznego wybranych LGD}

Struktura kapitału społecznego wybranych lokalnych grup działania reprezentujących województwa, na terenie których funkcjonuje najmniej organizacji tego typu (LGD ze zbioru I) różni się nieco od struktury tegoż kapitału w lokalnych grupach działania reprezentujących województwa, na terenie których takich organizacji działa relatywnie najwięcej (LGD ze zbioru II). Odmienny jest zarówno poziom poszczególnych komponentów kapitału społecznego, jak i ich wzajemne relacje.

Zaczynając od pierwszego z wyróżnionych komponentów, tj. zaufania, należy zauważyć jego nieco wyższy poziom w LGD ze zbioru pierwszego w stosunku do LGD ze zbioru drugiego (średnia wartość syntetycznego wskaźnika zaufania wyniosła w zbiorze pierwszym 4,01 punktu (w skali 0-6), podczas gdy w zbiorze drugim wyniosła ona 3,94 punktu). Wprawdzie w obu zbiorach najwyższe wartości wskaźnika (co najmniej 5 punktów w skali 0-6 punktów) uzyskały podobne odsetki osób (39\% w zbiorze I oraz 36\% w zbiorze II), jednak w drugim z nich było więcej osób charakteryzujących się najniższą wartością wskaźnika (maksymalnie 1 punkt na skali uzyskało 3\% badanych ze zbioru I oraz $8 \%$ badanych ze zbioru II).

Jednocześnie warto podkreślić nieco inny układ elementów składowych omawianego komponentu w obu zbiorach. W pierwszym z nich obserwujemy wyższy poziom zaufania do osób znanych oraz uogólnionego zaufania społecznego (w tym przypadku różnica jest mniejsza niż w przypadku zaufania do osób znanych) oraz niższy poziom zaufania do instytucji, niż ma to miejsce w zbiorze II [por. tabela 49]. 
Tabela 49. Wartość elementów składowych komponentu zaufania w LGD z porównywanych zbiorów

\begin{tabular}{|l|l|c|c|c|c|}
\hline \multicolumn{2}{|c|}{ Składowe komponentu zaufania } & \multicolumn{2}{|c|}{$\begin{array}{c}\text { Odsetek badanych, u których odnotowano } \\
\text { określony poziom komponentu (w \%) }\end{array}$} & $\begin{array}{c}\text { Średnia wartość } \\
\text { wskaźnika }\end{array}$ \\
\cline { 3 - 6 } & $0-$ niski & $1-$ średni & $2-$ wysoki & \\
\hline \multirow{2}{*}{$\begin{array}{l}\text { Zaufanie do osób } \\
\text { znanych }\end{array}$} & LGD ze zbioru I & 3 & 27 & 70 & 1,67 \\
\cline { 2 - 6 } & LGD ze zbioru II & 6 & 32 & 62 & 1,55 \\
\hline $\begin{array}{l}\text { Zaufanie } \\
\text { społeczne }\end{array}$ & LGD ze zbioru I & 12 & 64 & 24 & 1,12 \\
\cline { 2 - 6 } $\begin{array}{l}\text { Zaufanie } \\
\text { do instytucji }\end{array}$ & LGD ze zbioru II & 13 & 70 & 17 & 1,04 \\
\cline { 2 - 6 } & LGD ze zbioru I & 10 & 62 & 28 & 1,19 \\
\hline
\end{tabular}

Źródło: opracowanie własne.

Zaobserwowana prawidłowość nasuwa przypuszczenie, że w lokalnych grupach działania, należących do zbioru pierwszego, mamy do czynienia z wyższym poziomem zaufania, ale przede wszystkim horyzontalnego, skierowanego głównie na osoby już znane, z którymi członkowie organizacji pozostają w stałych, znanych relacjach. Ten typ zaufania sprzyja budowaniu raczej kapitału wiążącego niż pomostowego.

Bardziej otwarte na współpracę z instytucjami okazały się osoby współtworzące LGD ze zbioru drugiego, choć w grupach reprezentujących oba zbiory znajdowały się bardzo zbliżone odsetki przedstawicieli sektora publicznego i społecznego.

Uprawniających do analogicznych wniosków różnic między porównywanymi zbiorami nie odnotowano w przypadku komponentu norm i wartości. W obu zbiorach znalazły się podobne odsetki badanych o najwyższym poziomie komponentu (co najmniej 5 punktów w skali o maksymalnej wartości 6 punktów uzyskało aż 63\% członków LGD z pierwszego zbioru i 62\% członków LGD z drugiego zbioru) i nie znalazła się ani jedna osoba, która uzyskałaby jego bardzo niski poziom (najniższą odnotowaną wartością w skali 0-6 punktów były 2 punkty uzyskane zaledwie przez 1 badanego z pierwszego zbioru).

Wprawdzie średnia wartość syntetycznego wskaźnika wyrażającego poziom analizowanego komponentu w postaci wartości liczbowej była nieco niższa w przypadku zbioru drugiego (wynosiła ona 4,81 punktu w zbiorze pierwszym oraz 4,74 punktu w zbiorze drugim), jednak nie wiązało się to z widocznymi różnicami wartości elementów składowych tego komponentu [por. tabela 50]. 
Tabela 50. Wartość elementów składowych komponentu norm i wartości w LGD z porównywanych zbiorów

\begin{tabular}{|l|l|c|c|c|c|}
\hline \multirow{2}{*}{$\begin{array}{c}\text { Składowe komponentu norm } \\
\text { i wartości }\end{array}$} & \multicolumn{2}{c|}{$\begin{array}{c}\text { Odsetek badanych, u których odnotowano } \\
\text { określony poziom komponentu (w \%) }\end{array}$} & $\begin{array}{c}\text { Średnia wartośćc } \\
\text { wskaźnika }\end{array}$ \\
\cline { 3 - 6 } & $0-$ niski & $1-$ średni & $2-$ wysoki & \\
\hline \multirow{2}{*}{$\begin{array}{l}\text { Patriotyzm } \\
\text { lokalny }\end{array}$} & LGD ze zbioru I & 1 & 24 & 75 & 1,74 \\
\cline { 2 - 6 } & LGD ze zbioru II & 4 & 19 & 76 & 1,72 \\
\hline \multirow{2}{*}{\begin{tabular}{l} 
Normy społeczne \\
\cline { 2 - 6 }
\end{tabular}} & LGD ze zbioru I & 1 & 45 & 54 & 1,53 \\
\cline { 2 - 6 } $\begin{array}{l}\text { Normy i wartości } \\
\text { zw. z uczestnic- } \\
\text { twem w LGD }\end{array}$ & LGD ze zbioru I & - & 48 & 51 & 1,51 \\
\cline { 2 - 6 } & LGD ze zbioru II & - & 49 & 51 & 1,52 \\
\hline
\end{tabular}

Źródło: opracowanie własne.

Tabela 51. Wartości elementów składowych komponentu sieci w LGD z porównywanych zbiorów

\begin{tabular}{|l|l|c|c|c|c|}
\hline \multicolumn{2}{|c|}{ Składowe komponentu sieci } & \multicolumn{2}{|c|}{$\begin{array}{c}\text { Odsetek badanych, u których odnotowano } \\
\text { określony poziom komponentu (w \%) }\end{array}$} & $\begin{array}{c}\text { Średnia wartość } \\
\text { wskaźnika }\end{array}$ \\
\cline { 3 - 6 } & $0-$ niski & $1-$ średni & $2-$ wysoki & \\
\hline $\begin{array}{l}\text { Praca na rzecz } \\
\text { gminy/partner- } \\
\text { stwa }\end{array}$ & LGD ze zbioru I & 13 & 54 & 33 & 1,21 \\
\cline { 2 - 6 } $\begin{array}{l}\text { Uczestnictwo } \\
\text { w pracach LGD }\end{array}$ & LGD ze zbioru II & 17 & 64 & 19 & 1,02 \\
\cline { 2 - 6 } & LGD ze zbioru II & 16 & 72 & 12 & 1,26 \\
\hline $\begin{array}{l}\text { Poczucie wpływu } \\
\text { na funkcjonowa- } \\
\text { nie partnerstwa }\end{array}$ & LGD ze zbioru I & 4 & 72 & 24 & 1,96 \\
\cline { 2 - 6 } & LGD ze zbioru II & 10 & 67 & 23 & 1,13 \\
\hline
\end{tabular}

Źródło: opracowanie własne.

Największą różnicę między lokalnymi grupami z obu analizowanych zbiorów odnotowano w poziomie komponentu sieci. Co czwarty badany ze zbioru pierwszego uzyskał co najmniej 5 punktów w siedmiopunktowej skali (0-6 punktów) obrazującej poziom komponentu sieci, podczas gdy w zbiorze drugim wartość taką odnotowano tylko u co dziewiątego respondenta. $\mathrm{Z}$ kolei w zbiorze drugim znalazło się 8\% członków LGD z najniższymi (nieprzekraczającymi 1 punktu) wartościami wskaźnika, gdy w zbiorze pierwszym osoby takie stanowiły zaledwie $2 \%$ ogółu. W związku z tym nie budzi zdziwienia fakt, iż zarówno średnia 
wartość komponentu sieci jako całości, jak i średnie wartości jego poszczególnych elementów składowych były znacząco wyższe w zbiorze pierwszym niż w zbiorze drugim. Średnia wartość wskaźnika globalnego wyniosła odpowiednio 3,72 punktu i 3,19 punktu (w siedmiostopniowej skali od 0 do 6 punktów). Wartości wskaźników wszystkich elementów składowych zaprezentowano w tabeli 51.

Bezpośrednim efektem zaprezentowanych powyżej relacji między poziomem poszczególnych komponentów kapitału społecznego w porównywanych grupach jest jego wyższy poziom w LGD reprezentujących zbiór I. Aż $44 \%$ badanych z województw, na terenie których funkcjonuje najmniejsza liczba organizacji tego typu charakteryzuje się co najmniej wysokim poziomem kapitału społecznego, podczas gdy w zbiorze rekrutującym się z województw o największej liczbie LGD odsetek ten wynosi $26 \%$. W zbiorze drugim jest także więcej osób cechujących się niskim poziomem kapitału społecznego niż w zbiorze pierwszym (odpowiednio $30 \%$ i $23 \%$ składu grupy - por. wykres 12 ).

Wykres 12. Poziom kapitału społecznego w grupach z pierwszego i drugiego zbioru

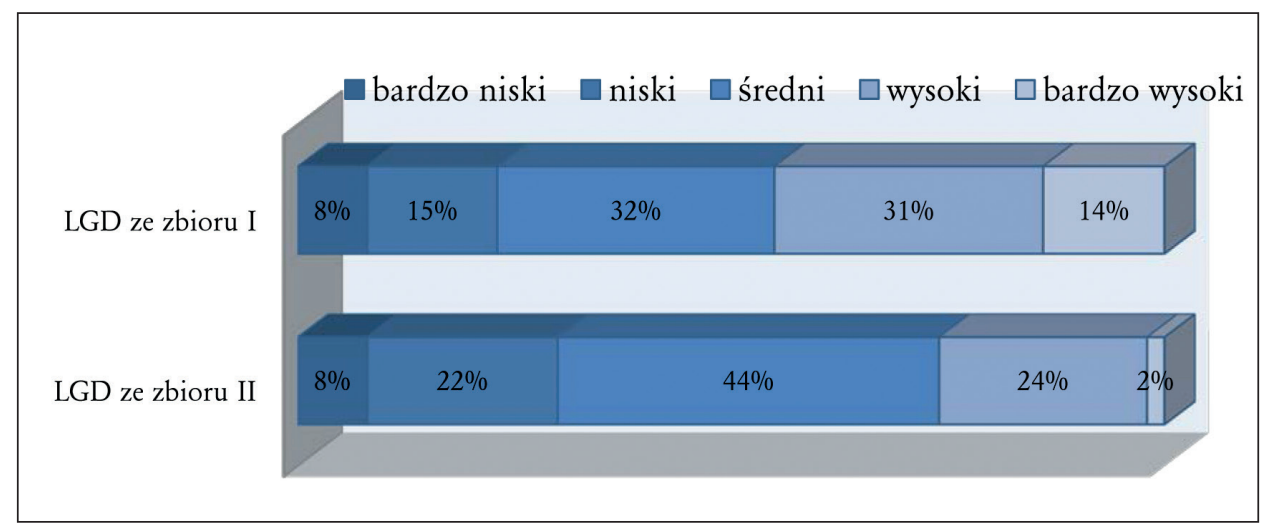

Źródło: opracowanie własne.

Jednocześnie warto zauważyć większą spójność kapitału społecznego lokalnych grup działania ze zbioru I. Między wszystkimi komponentami kapitału społecznego członków tych grup odnotowano zależności istotne statystycznie. Stosunkowo najsilniejszy związek $(r=0,46)$ łączył komponent norm i wartości oraz komponent sieci. Zależności między pozostałymi komponentami były nieco słabsze (na poziomie $r=0,32$ ) - por. tabela 52 .

Między poziomem komponentów kapitału społecznego charakteryzującym członków LGD z II zbioru (funkcjonujących na obszarach, na którym działa najliczniejsza sieć lokalnych grup działania) w zasadzie nie odnotowano zależności. Słaby związek $(r=0,23, p=0,05)$ łączył jedynie komponent zaufania i komponent sieci. A zatem poziom kapitału społecznego członków organizacji należących do zbioru II był niższy, zaś struktura tego kapitału bardziej rozproszona. 
Tabela 52. Związek między komponentami kapitału społecznego w LGD ze zbioru I

\begin{tabular}{|l|l|l|l|}
\hline \multicolumn{1}{|c|}{ Komponenty } & Komponent sieci & $\begin{array}{c}\text { Komponent norm } \\
\text { i wartości }\end{array}$ & \multicolumn{1}{|c|}{$\begin{array}{c}\text { Komponent } \\
\text { zaufania }\end{array}$} \\
\hline Komponent sieci & & $0,46^{* *}$ & $0,32^{* *}$ \\
\hline Komponent norm i wartości & $0,46^{* *}$ & & $0,32^{* *}$ \\
\hline Komponent zaufania & $0,32^{* *}$ & $0,32^{* *}$ & \\
\hline
\end{tabular}

Współczynniki korelacji $r$ Pearsona $* * \mathrm{p}=0,01$, test dwustronny.

Źródło: opracowanie własne.

Konkludując - kapitał społeczny grup z I zbioru wydaje się bardziej koherentny i osiąga wyższy poziom. Jednak przy interpretacji tego faktu należy wziąć pod uwagę także dwa typy czynników mogących modyfikować jej jednoznacznie pozytywny (dla zbioru I) wydźwięk. Po pierwsze, próba miała charakter samorzutny i do badania zgłosiło się znacznie mniej przedstawicieli LGD ze zbioru I. Analizując ich charakterystyki społeczno-demograficzne, można przypuszczać, że były to w swoich grupach osoby najaktywniejsze i najbardziej otwarte, cechujące się najwyższym poziomem kapitału ludzkiego, ekonomicznego i społecznego. Uzyskany rezultat w ograniczonym zakresie może przekładać się na pozostałych członków grupy.

Po drugie, kapitał społeczny LGD ze zbioru I w wymiarze zaufania opiera się przede wszystkim na jego aspekcie horyzontalnym. Może to oznaczać, iż członkowie tych grup są bardziej niż członkowie grup ze zbioru drugiego skłonni do pracy w gronie i na rzecz osób sobie znanych, koncentrują swoje działania wokół spraw dotyczących stosunkowo wąskiego kręgu mieszkańców partnerstwa, mniej chętnie wchodzą w bardziej złożone relacje wymagające większej innowacyjności i otwartości (o tym świadczyłby także charakter realizowanych projektów stosunkowo mniejsza w porównaniu ze zbiorem II liczba projektów współpracy). Można przypuszczać, że ich kapitał społeczny jest wysoki, ale nie generuje wzrostu poziomu kapitału społecznego mieszkańców partnerstwa, ma raczej charakter wiążący, nie pomostowy.

\subsection{Poziom aktywności gospodarczej na obszarze partnerstw terytorialnych a poziom kapitału społecznego LGD}

Dobór wskaźników aktywności gospodarczej na obszarze partnerstw sprawiał wiele problemów. Zamierzano uwzględnić wnioski płynące z analizy literatury 
przedmiotu w tej kwestii oraz dobrać wskaźniki tak, by odzwierciedlały specyfikę działalności gospodarczej prowadzonej na wsi (tj. zarówno działalność rolniczą, jak i pozarolniczą).

Wskaźniki aktywności gospodarczej stosowane przez polskich badaczy okazały się bardzo różne, m.in. w zależności od obiektu ich analizy (gmina, powiat, województwo) czy dostępności danych. Dla przykładu, analizując rozwój gospodarczy na poziomie poszczególnych województw, J. Heller zwrócił uwagę tylko na ich udział w PKB [2008: 10], W. Dziemianowicz uwzględnił PKB na mieszkańca, wielkość dochodów na mieszkańca, wartość sprzedaży, strukturę sektorową wartości dodanej brutto, udział województw w krajowym eksporcie, liczbę podmiotów gospodarczych na mieszkańca, nakłady na $\mathrm{B}+\mathrm{R}$ w relacji do $\mathrm{PKB}$, liczbę patentów na 100000 mieszkańców [Dziemianowicz i in. 2009: 15-17). A. Rosner, prowadząc analizy dotyczące zróżnicowania sytuacji gospodarczej gmin, uwzględnił z kolei: stopę bezrobocia jawnego, stopę bezrobocia ukrytego w rolnictwie indywidualnym, odsetek pozarolniczych podmiotów gospodarczych, liczbę pracujących poza rolnictwem indywidualnym w relacji do ludności w wieku produkcyjnym, udział podmiotów z kapitałem zagranicznym oraz prywatnych podmiotów działających w zakresie edukacji, ochrony zdrowia i opieki społecznej w relacji do podmiotów zarejestrowanych w systemie REGON, odsetek indywidualnych gospodarstw rolnych prowadzących działalność rolniczą głównie na rynek w 1996 r., odsetek użytkowników indywidualnych gospodarstw rolnych utrzymujących się z pracy we własnym gospodarstwie, oceniających je jako rozwojowe, dochody budżetu gminy z tytułu udziału w dochodach budżetu państwa pochodzących z podatku od osób fizycznych i osób prawnych w przeliczeniu na 1 mieszkańca, dochody własne gminy w przeliczeniu na 1 mieszkańca [Rosner 2002: 12-13].

Trudności w doborze wskaźników wynikały również z problemów z dostępem do wiarygodnych, kompletnych i aktualnych danych zastanych. $Z$ tego rodzaju problemami mierzyło się zresztą wielu badaczy. A. Rosner podsumowując badania prowadzone w Instytucie Rozwoju Wsi i Rolnictwa PAN (dotyczące zróżnicowania obszarów wiejskich w Polsce) stwierdza:

Na etapie doboru wskaźników powstały bardzo duże problemy związane z dostępnością materiału empirycznego. Problemy te wynikały z trudności uzyskania danych aktualnych, merytorycznie odpowiadającym potrzebom badawczym oraz agregowanych według obecnego podziału terytorialnego w układzie gmin [Rosner 2002: 11] .

Okazało się, że m.in. nie będzie można oszacować struktury agrarnej obszaru partnerstw, ani na podstawie danych z ostatniego spisu rolnego (w momencie badania Główny Urząd Statystyczny nie opracował ich jeszcze dla wszystkich gmin), ani w oparciu o publikacje Banku Danych Lokalnych (jego bazy były niekompletne). 
Ostatecznie do wymiarów sfery gospodarczej, na podstawie których zamierzano zweryfikować hipotezę mówiącą o jednokierunkowym związku poziomu gospodarczego rozwoju obszaru, na rzecz którego funkcjonują lokalne grupy działania i poziomu kapitału społecznego tychże grup, zgodnie z przyjętymi założeniami, weszły ${ }^{7}$ struktura gospodarstw rolnych obszarów partnerstw w 2010 r., stopa bezrobocia na obszarze partnerstw w 2010 r., liczba grup producentów rolnych (na obszarze partnerstw) w 2010 r. oraz liczba firm prowadzonych przez osoby fizyczne poza sektorem rolnym (na obszarze partnerstwa) w $2010 \mathrm{r}$.

\subsubsection{Struktura gospodarstw rolnych obszaru partnerstw w $2010 \mathrm{r}$.}

W związku z wyżej opisanymi problemami dotyczącymi dostępu do danych zastanych, na podstawie których możliwe było oszacowanie średniej wielkości gospodarstw rolnych na obszarze poszczególnych partnerstw zwrócono się z prośbą o jej podanie do urzędów poszczególnych gmin (mając na uwadze, iż nie są one zobowiązane do ich agregowania, w związku z czym w zbiorze pojawiają się braki danych). Otrzymane dane weryfikowano m.in. porównując je z wynikami badań zrealizowanych przez J. Bożek w 2007 r.

Autorka na podstawie prowadzonych analiz empirycznych wyszczególniła cztery grupy obszarowe gospodarstw rolnych. Grupę pierwszą, w której znalazły się województwa: łódzkie, mazowieckie, lubelskie, wielkopolskie, dolnośląskie, opolskie, pomorskie i zachodniopomorskie, cechowało mniejsze (w porównaniu do innych) rozdrobnienie agrarne. Gospodarstw bardzo małych (do 5 ha) było tu $50,3 \%$, małych (do 10 ha) 24,3\%, średnich (10-20 ha) - 16,3\%, dużych i bardzo dużych 9,1\%. W grupie drugiej znalazły się województwa: małopolskie, śląskie, podkarpackie i świętokrzyskie. Cechowała ją najbardziej rozdrobniona struktura agrarna - gospodarstwa bardzo małe i małe stanowiły tu aż 94,3\% ogółu. W grupie trzeciej znalazły się gospodarstwa z podlaskiego, warmińsko-mazurskiego oraz kujawsko-pomorskiego, cechujące się najkorzystniejszą strukturą agrarną. Udział gospodarstw do 10 ha był tutaj najniższy spośród wszystkich grup typologicznych $(55,4 \%)$.

Województwo lubuskie w 2002 r. J. Bożek potraktowała jako odrębną grupę typologiczną - gospodarstwa od 1 do 5 ha stanowiły tu $63,3 \%$ wszystkich gospodarstw. W okresie 2002-2007 na tym obszarze dokonały się jednak

${ }^{7}$ Ustalenie liczby gospodarstw rolnych na obszarze partnerstw prowadzących działalność rolniczą i pozarolniczą oraz gospodarstw rolnych prowadzących wyłącznie działalność pozarolniczą w 2010 r. nie było możliwe. Dane z ostatniego spisu rolnego były niedostępne. W Banku Danych Lokalnych statystyki pochodziły z 2002 r. (były mocno zdezaktualizowane i nie warte uwzględnienia w badaniach). Takimi danymi nie dysponowały również urzędy gmin. 
na tyle intensywne przekształcenia struktury agrarnej, iż w 2007 r. zostało ono zaliczone do grupy pierwszej [Bożek 2010: 29-30].

Według pozyskanych danych zastanych, dominujący - ze względu na wielkość - typ gospodarstw rolnych na terenach, na których funkcjonują badane LGD stanowią gospodarstwa małe i średnie, nie przekraczające 10 ha. Na obszarze funkcjonowania siedmiu z osiemnastu analizowanych partnerstw przeważają gospodarstwa liczące od około 5 do około 10 ha (KOLD, Ostrzeszowska LGD, Subregion Magurski, Dolina Stobrawy, EURO COUNTRY, Fundacja Porozumienie Wzgórz Dałkowskich, Partnerstwo Borów Niemodlińskich). Znajdują się one przede wszystkim w województwach wielkopolskim i opolskim, a więc zarówno na terenach charakteryzujących się największą liczbą LGD, jak i funkcjonujących na terenach o najmniejszej ich liczbie.

Kolejnych sześć partnerstw działa na obszarach, na których dominują gospodarstwa rolne nie przekraczające 5 ha (CK Podkarpacie, Dolina Karpia, Lasovia, LGD Dunajec-Biała, Partnerstwo dla Ziemi Niżańskiej, Prokopara). Wszystkie te organizacje funkcjonują na terenach, na których istnieje największa liczba lokalnych grup działania (województwa małopolskie i podkarpackie).

Pozostałe pięć grup (LGD Regionu Kozła i Fundacja Zielonej Doliny Odry i Warty z województwa lubuskiego oraz wszystkie grupy z województwa zachodniopomorskiego) obejmują swoim działaniem tereny, na których przeważają gospodarstwa duże, liczące ponad 10 ha. Jednocześnie są to obszary, na których funkcjonuje najmniejsza liczba lokalnych grup działania. A zatem wyniki analizy korespondują z tymi, które otrzymała J. Bożek, co uwiarygodnia rzetelność pozyskanych danych zastanych. W różnych i jednorodnych zbiorach znalazły się gospodarstwa z partnerstw ulokowanych na obszarze Wielkopolski i Opolszczyzny oraz na obszarze Małopolski i Podkarpacia. W trzecim zbiorze wyróżniono LGD z województwa lubuskiego i zachodniopomorskiego, które w 2007 r. również J. Bożek zaliczyła do jednego zbioru.

Przeprowadzona analiza dowiodła, iż dynamika rozwoju LGD nie jest pozytywnie uwarunkowana strukturą gospodarstw rolnych na obszarze ich funkcjonowania. Tereny, na których występuje najmniejsza liczba lokalnych grup działania charakteryzują się korzystniejszą (mniej rozdrobnioną) strukturą gospodarstw rolnych [por. tabela 53].

\subsubsection{Stopa bezrobocia na obszarze partnerstw w 2010 r. $^{8}$}

Obszary objęte wsparciem badanych LGD to w większości gminy o stosunkowo niskim poziomie bezrobocia. Na terenie działania ośmiu z osiemnastu ana-

\footnotetext{
${ }^{8}$ Wartość zmiennej określano na podstawie danych za 2010 r. z Banku Danych Lokalnych.
} 
lizowanych partnerstw (wszystkich z województw wielkopolskiego i opolskiego, LGD Dunajec - Biała i Doliny Karpia z małopolskiego oraz LGD Regionu Kozła z lubuskiego) średni odsetek bezrobotnych zarejestrowanych w liczbie ludności w wieku produkcyjnym jest niższy niż 7\%. Warto dodać, iż w grupie tej znajduje się taka sama liczba partnerstw ze zbioru I (grup aktywnych na obszarach charakteryzujących się najmniejszą siecią LGD) oraz ze zbioru II (funkcjonujących w ramach stosunkowo największych sieci LGD, działających na rzecz mieszkańców tego samego województwa).

Kolejnych sześć grup (dwie pozostałe z województwa lubuskiego, PROKOPARA z małopolskiego, Szanse Bezdroży Gmin Powiatu Goleniowskiego i Lider Pojezierza z zachodniopomorskiego oraz Lasovia z podkarpackiego) prowadzi swoją aktywność na terenach charakteryzujących się umiarkowanym poziomem bezrobocia - średni odsetek bezrobotnych zarejestrowanych w liczbie ludności w wieku produkcyjnym wynosi tu od 7,1 do $12 \%$.

Ostatnie cztery grupy (trzy pozostałe z województwa podkarpackiego oraz Fundacja Środkowopomorska GD) funkcjonują na obszarach, na których średni odsetek bezrobotnych zarejestrowanych w liczbie ludności w wieku produkcyjnym przekracza $12 \%$ [por. tabela 53].

Poziom bezrobocia na terenach partnerstw należących do obu zbiorów wyróżnionych ze względu na liczebność LGD funkcjonujących na obszarze ich działania jest podobny. Co prawda, nieco więcej grup ze zbioru II działa na obszarach charakteryzujących się stosunkowo najwyższym poziomem bezrobocia, ale różnice pomiędzy zbiorami są na tyle niewielkie, że nie uprawniają do wysnucia wniosku o generalnie niższym poziomie bezrobocia na obszarze funkcjonowania grup ze zbioru I.

\subsubsection{Liczba grup producentów rolnych (na obszarze partnerstw) w 2010 r. ${ }^{9}$}

Kolejny rozważany wymiar sfery gospodarczej stanowiącej „zaplecze” aktywności badanych organizacji to liczba grup producentów rolnych prowadzących działalność na obszarach objętych działaniami LGD. Istnienie tego rodzaju zrzeszeń może świadczyć o lepszej kondycji gospodarstw rolnych (zrzeszone mogą sprzedać więcej swoich produktów), a zarazem o większej skłonności ich właścicieli do współpracy, być może również w takich organizacjach jak lokalne grupy działania.

${ }^{9}$ W badaniach zaobserwowano rozbieżność pomiędzy statystykami Krajowej Sieci Obszarów Wiejskich oraz Agencji Restrukturyzacji i Modernizacji Rolnictwa. W analizach brano pod uwagę drugi z rejestrów (uwzględniający dane za 2012 r.). 
W badanej zbiorowości mamy, pod tym względem, wyraźny podział na partnerstwa funkcjonujące na terenach, gdzie nie zarejestrowano żadnej grupy producentów rolnych oraz partnerstwa funkcjonujące na terenach, gdzie wspomniana forma przedsiębiorczości wydaje się dość szeroko rozpowszechniona. Z pierwszą z opisanych sytuacji mamy do czynienia przede wszystkim w przypadku organizacji ze zbioru II (grup funkcjonujących na terenach, na których działa największa liczba LGD), z województw podkarpackiego i małopolskiego. Sytuacja druga jest charakterystyczna głównie dla partnerstw ze zbioru I, działających w województwach: lubuskim, opolskim i zachodniopomorskim (LGD funkcjonujących na terenach, na których działa najmniejsza liczba organizacji tego typu). Opisuje ona jednak także grupy z województwa wielkopolskiego, wchodzące w skład zbioru II [por. tabela 53].

\subsubsection{Liczba firm prowadzonych przez osoby fizyczne poza sektorem rolnym (na obszarze partnerstwa) w 2010 r. $^{10}$}

Analogicznie do liczby producentów rolnych prowadzących działalność na obszarach, na których funkcjonują badane LGD, kształtuje się także średnia liczba osób fizycznych, prowadzących pozarolniczą działalność gospodarczą na terenie każdej z gmin objętych działaniami grup. Na terenie większości gmin wchodzących w skład partnerstw należących do zbioru II (przede wszystkim z województwa podkarpackiego) odnotowano relatywnie najmniejsze średnie liczby przedsiębiorców funkcjonujących poza sektorem rolnym (średnio poniżej 500 osób prowadzących działalność w każdej z gmin partnerstwa), zaś na obszarze większości gmin z partnerstw należących do zbioru I (przede wszystkim z województwa zachodniopomorskiego) liczby te były stosunkowo największe (średnio powyżej 700 osób fizycznych prowadzących działalność w każdej z gmin partnerstwa). Jednakże wśród grup należących do obu zbiorów znalazły się organizacje znacząco odbiegające od opisanej prawidłowości. Na przykład na obszarze działania LGD z województwa wielkopolskiego odnotowano stosunkowo dużą liczbę przedsiębiorców przypadającą na każdą gminę wchodzącą w skład obu partnerstw (powyżej 650 osób). Z kolei na obszarze działania LGD EURO COUNTRY z województwa opolskiego odnotowano relatywnie niewielką średnią liczbę (439) osób fizycznych, prowadzących działalność w każdej z gmin partnerstwa [por. tabela 53].

${ }^{10}$ Szacując wartość zmiennej odwołano się do danych z Banku Danych Lokalnych za 2010 r. 


\begin{tabular}{|c|c|c|c|c|c|c|c|c|c|c|}
\hline 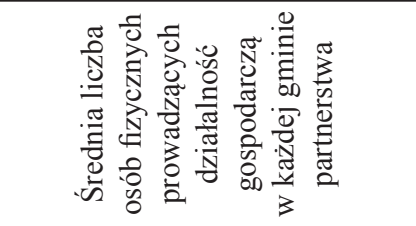 & $a$ & $\sqrt{6}$ & $\overline{2}$ & $\stackrel{n}{\vartheta}$ & $\stackrel{n}{n}$ & $\frac{0}{6}$ & $\begin{array}{l}\infty \\
\infty \\
m\end{array}$ & $\stackrel{m}{\sim}$ & $\underset{\infty}{\infty}$ & $\underset{n}{\stackrel{N}{n}}$ \\
\hline 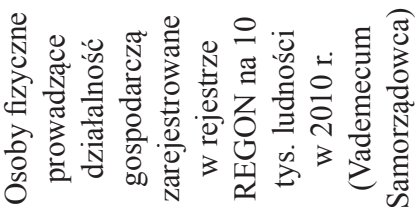 & $\infty$ & $\begin{array}{l}n \\
\tilde{n} \\
\sigma\end{array}$ & ڤे & $\stackrel{\cong}{\cong}$ & ్ㅗ & $\frac{\circ}{\stackrel{m}{\vartheta}}$ & $\stackrel{\circ}{\stackrel{2}{2}}$ & $\stackrel{m}{\text { లి }}$ & $\stackrel{\text { 巳 }}{=}$ & 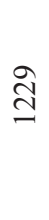 \\
\hline 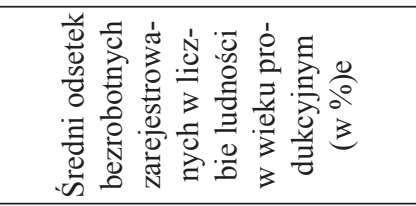 & $r$ & $\begin{array}{l}\text { ֻे } \\
\text { రీ }\end{array}$ & $\stackrel{\Re}{\underset{f}{*}}$ & $\begin{array}{l}6 \\
6 \\
6\end{array}$ & $\stackrel{\infty}{2}$ & $\underset{6}{ \pm}$ & $\begin{array}{l}n \\
\tilde{d} \\
\dot{J}\end{array}$ & $\begin{array}{l}\infty \\
\infty \\
\text { I }\end{array}$ & $\stackrel{n}{=}$ & $\begin{array}{l}\stackrel{+}{+} \\
\text { İ }\end{array}$ \\
\hline 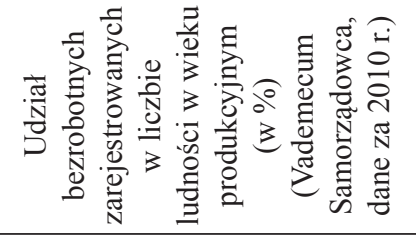 & 0 & $\begin{array}{l}\vec{\pi} \\
\text { in } \\
n\end{array}$ & 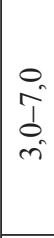 & $\begin{array}{l}\hat{b} \\
1 \\
\hat{\sigma}\end{array}$ & $\begin{array}{l}n \\
\hat{j} \\
0 \\
0\end{array}$ & $\begin{array}{l}1 \\
\infty \\
\infty \\
\infty\end{array}$ & \begin{tabular}{l}
\multirow{2}{\pm}{} \\
\multirow{1}{\alpha}{} \\
$\stackrel{2}{2}$
\end{tabular} & $\begin{array}{l}\tilde{y} \\
\vdots \\
n \\
0\end{array}$ & $\begin{array}{l}\sigma_{0} \\
\stackrel{1}{\alpha} \\
\sigma\end{array}$ & $\begin{array}{l}n \\
n \\
n \\
n\end{array}$ \\
\hline 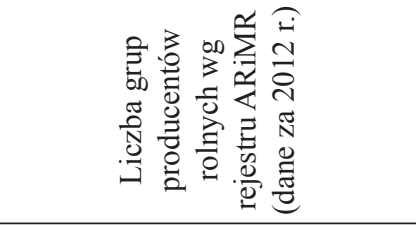 & in & $\nabla$ & $N$ & 0 & $\sim$ & 0 & 0 & 0 & 0 & 0 \\
\hline 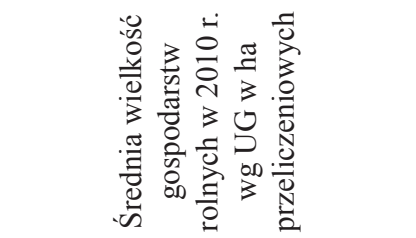 & $\nabla$ & $\begin{array}{l}\frac{m}{i} \\
j \\
i\end{array}$ & $\begin{array}{l}n \\
n \\
n \\
1 \\
a \\
j\end{array}$ & 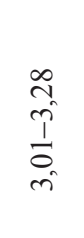 & $\begin{array}{l}7 \\
\dot{y} \\
\dot{5} \\
n\end{array}$ & $\begin{array}{l}\stackrel{n}{=} \\
\frac{1}{a} \\
=\end{array}$ & 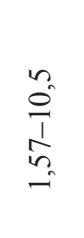 & $\begin{array}{l}\text { I } \\
\hat{j} \\
\hat{\infty} \\
\infty\end{array}$ & $\begin{array}{l}m \\
\dot{m} \\
m\end{array}$ & $\begin{array}{l}\hat{j} \\
\infty \\
0\end{array}$ \\
\hline 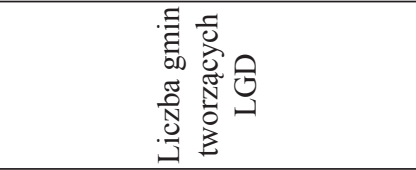 & $m$ & $r$ & $r$ & $\nabla$ & $\nabla$ & $r$ & $N$ & $r$ & $m$ & $m$ \\
\hline 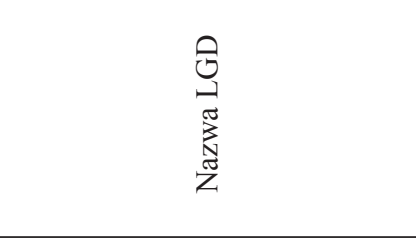 & 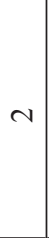 & 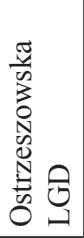 & $\begin{array}{l}\theta \\
0 \\
0 \\
1\end{array}$ & 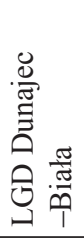 & $\begin{array}{l}\nwarrow \\
\frac{1}{1} \\
0 \\
0 \\
\frac{1}{0} \\
\frac{2}{2}\end{array}$ & 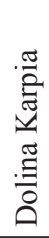 & 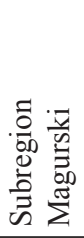 & 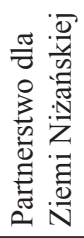 & 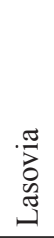 & 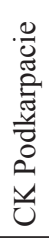 \\
\hline $\begin{array}{l}0 \\
\sum_{1}^{2} \\
\frac{1}{0} \\
0 \\
0 \\
0 \\
0 \\
3 \\
3\end{array}$ & - & \multicolumn{2}{|c|}{$\begin{array}{l}\frac{0}{0} \\
\frac{0}{0} \\
0 \\
\frac{0}{0} \\
\frac{0}{0} \\
\frac{0}{3}\end{array}$} & \multicolumn{3}{|c|}{$\begin{array}{l}\frac{0}{\frac{0}{n}} \\
\frac{0}{0} \\
\frac{0}{0} \\
\frac{\pi}{\pi}\end{array}$} & \multicolumn{4}{|c|}{$\begin{array}{l}\frac{0}{0} \\
\frac{\tilde{Z}}{0} \\
\frac{\tilde{Z}}{\bar{Z}} \\
0\end{array}$} \\
\hline
\end{tabular}




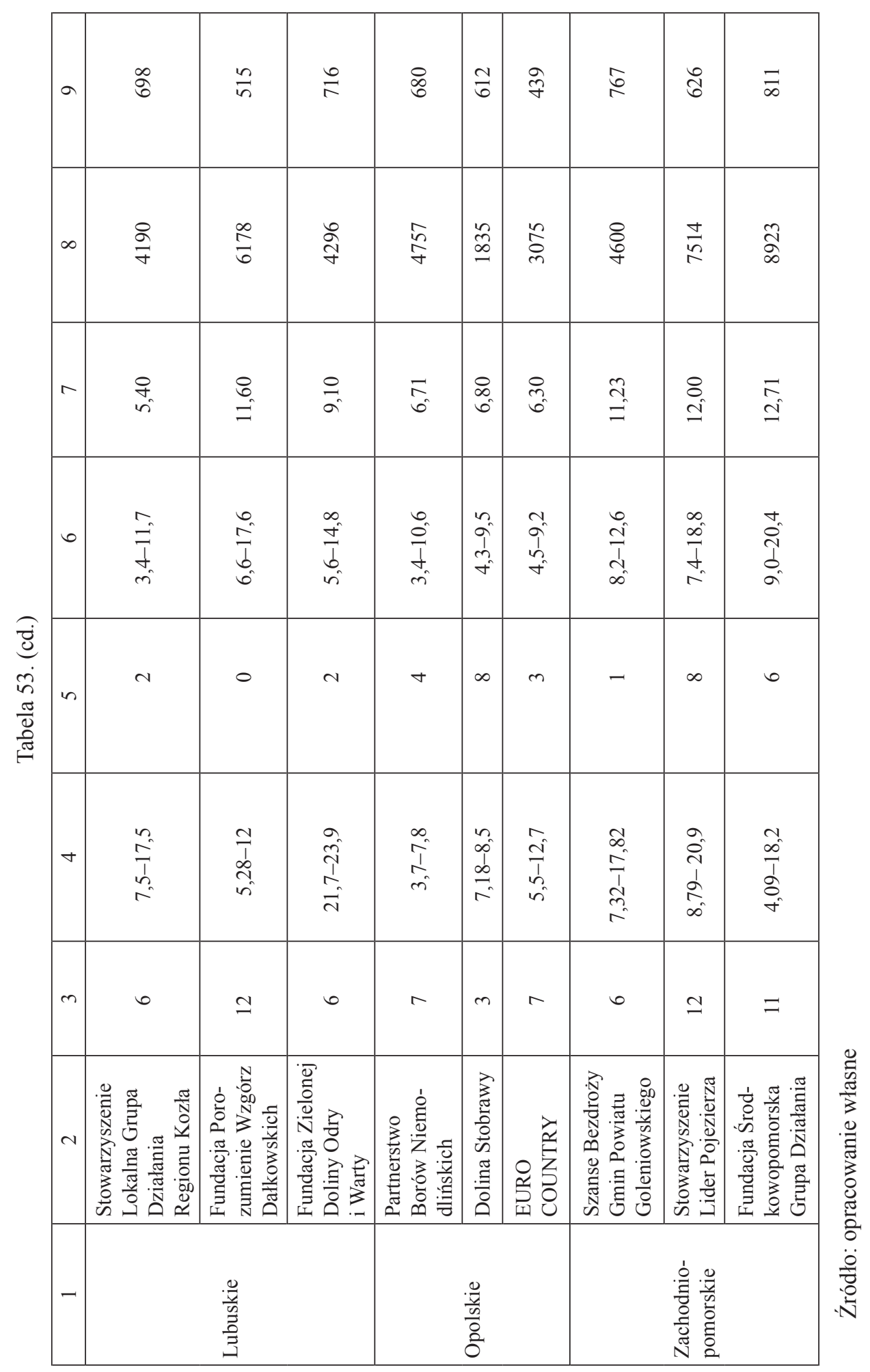




\subsubsection{Poziom kapitału społecznego w LGD funkcjonujących na obszarach o różnym poziomie rozwoju gospodarczego}

Zaprezentowany powyżej wstępny ogląd danych zastanych dotyczących sytuacji gospodarczej obszarów objętych funkcjonowaniem badanych grup mógłby skłaniać do wysunięcia hipotezy mówiącej, że wyższym poziomem rozwoju gospodarczego (mierzonego wartością zaproponowanych wskaźników) charakteryzują się tereny, na których działa mniejsza liczba LGD. Zważywszy na fakt, iż właśnie w partnerstwach funkcjonujących na obszarach charakteryzujących się mniejszym nasyceniem organizacjami tego typu (zbiór I) odnotowano wyższy poziom kapitału społecznego (por. rozdział 4.2). Hipoteza taka prowadziłaby do konstatacji, że między poziomem rozwoju gospodarczego a poziomem kapitału społecznego zachodzi pozytywny związek.

Od uznania takiego wniosku za ostateczny rezultat prowadzonych analiz powstrzymuje jednak fakt, iż w każdym z uwzględnionych obszarów sfery gospodarczej istnieje bardzo duże zróżnicowanie między badanymi partnerstwami. Co ważne, większe różnice pojawiają się często między partnerstwami pochodzącymi z tego samego zbioru (wyróżnionego ze względu na liczebność sieci LGD na badanym obszarze) niż między partnerstwami należącymi do różnych zbiorów. Ze względu na chęć możliwie pełnej i adekwatnej weryfikacji hipotezy dotyczącej uwarunkowań gospodarczych kapitału społecznego LGD, sytuacja taka skłania do odejścia od stosowanego we wcześniejszych rozdziałach podziału na lokalne grupy funkcjonujące na obszarze o najliczniejszych i najmniej licznych sieciach organizacji tego typu i sklasyfikowania ich według innego kryterium, pozwalającego skupić w odrębnych kategoriach te grupy, które funkcjonują w najbardziej zróżnicowanych warunkach gospodarczych ${ }^{11}$. Z tej perspektywy wyróżniono trzy kategorie LGD: działające na obszarach, w przypadku których większość założonych wskaźników osiągnęła wartość ponadprzeciętną ${ }^{12}$, przy czym żaden z nich nie uzyskał poziomu poniżej przeciętnego (oba partnerstwa z województwa wielkopolskiego, LGD Regionu Kozła i Fundacja Zielonej Odry i Warty z województwa lubuskiego, Partnerstwo Borów Niemodlińskich i Dolina Stobrawy z województwa opolskiego oraz Lider Pojezierza i Środkowopomorska GD), grupy funkcjonujące na obszarach, w przypadku których większość założonych wskaźników uzyskała wartość poniżej przeciętnej i żaden nie uzyskał wartości powyżej przeciętnej (wszystkie partnerstwa z Podkarpacia), grupy funkcjonujące na obszarach, w przypadku których część założonych wskaźników osiągnęła wartości powyżej, a część poniżej przeciętnej (wszystkie partnerstwa z województwa

${ }^{11}$ Ze względu na uzyskaną strukturę próby (niektóre grupy reprezentowało zaledwie kilka osób, od których nie zawsze udało się uzyskać kompletne dane) niemożliwe okazało się przeprowadzenie analiz na poziomie samych partnerstw.

12 W ramach każdego z analizowanych wymiarów wyróżniono trzy przedziały wartości. Podstawą do ich wyznaczenia była średnia uzyskiwana w danym wymiarze dla całej badanej grupy (18 partnerstw). 
małopolskiego, Porozumienie Wzgórz Dałkowskich z województwa lubuskiego oraz Szanse Bezdroży Gmin Powiatu Goleniowskiego z zachodniopomorskiego). W wyniku przeprowadzonego podziału uzyskano następującą strukturę próby:

- partnerstwa funkcjonujące na obszarze o ponadprzeciętnym poziomie rozwoju gospodarczego - 8 (łącznie 122 członków);

- partnerstwa funkcjonujące na obszarze o przeciętnym poziomie rozwoju gospodarczego - 6 (łącznie 97 członków);

- partnerstwa funkcjonujące na obszarze o niższym od przeciętnego poziomie rozwoju gospodarczego - 4 (łącznie 68 członków).

Tabela 54. Poziom komponentów kapitału społecznego w LGD funkcjonujących na obszarach o różnym poziomie rozwoju gospodarczego

\begin{tabular}{|c|c|c|c|}
\hline \multirow{2}{*}{$\begin{array}{c}\text { Komponenty kapitału } \\
\text { społecznego }\end{array}$} & \multicolumn{2}{|c|}{$\begin{array}{c}\text { Średnie wartości komponentów kapitału } \\
\text { społecznego LGD }\end{array}$} \\
\cline { 2 - 4 } & $\begin{array}{c}\text { z obszarów charakteryzujących się } \\
\text { poziomem } \\
\text { rozwoju } \\
\text { gospodarczego }\end{array}$ & $\begin{array}{c}\text { średnim } \\
\text { poziomem } \\
\text { rozwoju } \\
\text { gospodarczego }\end{array}$ & $\begin{array}{c}\text { niskim } \\
\text { poziomem } \\
\text { rozwoju } \\
\text { gospodarczego }\end{array}$ \\
\hline Zaufanie (0-6) & 3,77 & 4,07 & 4,16 \\
\hline do osób znanych (0-2) & 1,50 & 1,70 & 1,62 \\
\hline społeczne (0-2) & 1,04 & 1,09 & 1,09 \\
\hline do instytucji (0-2) & 1,16 & 1,21 & 1,41 \\
\hline Normy i wartości (0-6) & 4,76 & 4,68 & 4,90 \\
\hline patriotyzm lokalny (0-2) & 1,73 & 1,66 & 1,81 \\
\hline $\begin{array}{l}\text { normy i wartości związane z uczestnictwem } \\
\text { w LGD (0-2) }\end{array}$ & 1,49 & 1,55 & 1,54 \\
\hline normy społeczne (0-2) & 1,53 & 1,48 & 1,55 \\
\hline Sieci (0-6) & 3,31 & 3,68 & 3,20 \\
\hline $\begin{array}{l}\text { sieci współpracy na rzecz partnerstwa } \\
\text { lub gminy (0-2) }\end{array}$ & 1,13 & 1,06 & 1,06 \\
\hline uczestnictwo w pracach LGD (0-2) & 1,11 & 1,09 & 0,94 \\
\hline $\begin{array}{l}\text { poczucie wpływu na funkcjonowanie } \\
\text { partnerstwa (0-2) }\end{array}$ & 1,09 & 1,25 & 1,19 \\
\hline $\begin{array}{l}\text { Kapitał społeczny - suma komponentów } \\
\text { (0-18) }\end{array}$ & 11,84 & 12,88 & 11,94 \\
\hline
\end{tabular}

Źródło: opracowanie własne.

Analiza poziomu wszystkich opisanych wcześniej komponentów kapitału społecznego w kategoriach grup wyróżnionych ze względu na poziom rozwoju gospodarczego terenu, na którym (i na rzecz mieszkańców którego) grupy te działają 
wykazała stosunkowo najmniejsze różnice między badanymi grupami w ramach komponentu norm i wartości.

Relatywnie najwyższym jego poziomem (średnio 4,9 punktu w skali 0-6 punktów) charakteryzowali się członkowie grup funkcjonujących na obszarach o najniższym poziomie rozwoju gospodarczego, zaś poziomem najniższym (średnio 4,68 punktu w skali 0-6) charakteryzowali się członkowie grup funkcjonujących na obszarach o przeciętnym poziomie rozwoju gospodarczego. Relację odwrotną i stosunkowo największe różnice między badanymi kategoriami grup zaobserwowano w poziomie komponentu sieci. W przypadku tego komponentu, wyrażającego praktyczny aspekt kapitału społecznego, wartość najwyższa (średnio 3,68 punktu w skali 0-6) charakteryzowała członków grup z terenów o przeciętnym poziomie rozwoju gospodarczego, zaś wartość najniższa komponentu (średnio 3,2 punktu w skali 0-6) była właściwa członkom grup z terenów o najniższym poziomie rozwoju gospodarczego. W ramach ostatniego z wyróżnionych wymiarów kapitału społecznego - szeroko rozumianego zaufania do różnych grup aktorów życia społecznego - najwyższą jego wartość odnotowano wśród członków LGD z obszarów charakteryzujących się najniższym poziomem rozwoju gospodarczego (średnio 4,16 punktu w skali 0-6 punktów), zaś wartość relatywnie najniższą zaobserwowano u członków organizacji działających na obszarach o wysokim poziomie rozwoju gospodarczego [por. tabela 54].

Przeprowadzone badania pokazały, iż stosunkowo najwyższym poziomem kapitału społecznego (w ramach przyjętych wskaźników) charakteryzują się członkowie LGD funkcjonujących na obszarach o przeciętnym poziomie rozwoju gospodarczego. Średnia wartość syntetycznego wskaźnika kapitału społecznego (stanowiącego sumę wartości trzech komponentów) obliczona dla członków tych grup wyniosła 12,88 punktu w skali od 0 do 18 punktów, podczas gdy w pozostałych kategoriach nie osiągnęła ona 12 punktów (najmniejszą średnią wartość wskaźnika odnotowano w grupach działających na obszarach charakteryzujących się relatywnie wysokim poziomem rozwoju gospodarczego).

$\mathrm{W}$ organizacjach funkcjonujących na terenach, którym właściwy jest ponadprzeciętny poziom rozwoju gospodarczego, odsetek osób co najmniej o wysokim poziomie kapitału społecznego wyniósł $31 \%$, zaś w grupach działających na rzecz gmin o niższym od przeciętnego poziomie rozwoju gospodarczego analogiczny poziom kapitału społecznego charakteryzował tylko niespełna co czwartego ich członka. Wśród badanych z grup prowadzących swoją aktywność na obszarach o przeciętnym poziomie wskaźników rozwoju gospodarczego blisko połowa cechuje się co najmniej wysokim poziomem kapitału społecznego [por. wykres 13]. 
Wykres 13. Poziom kapitału społecznego członków LGD funkcjonujących na obszarach o różnym poziomie rozwoju gospodarczego

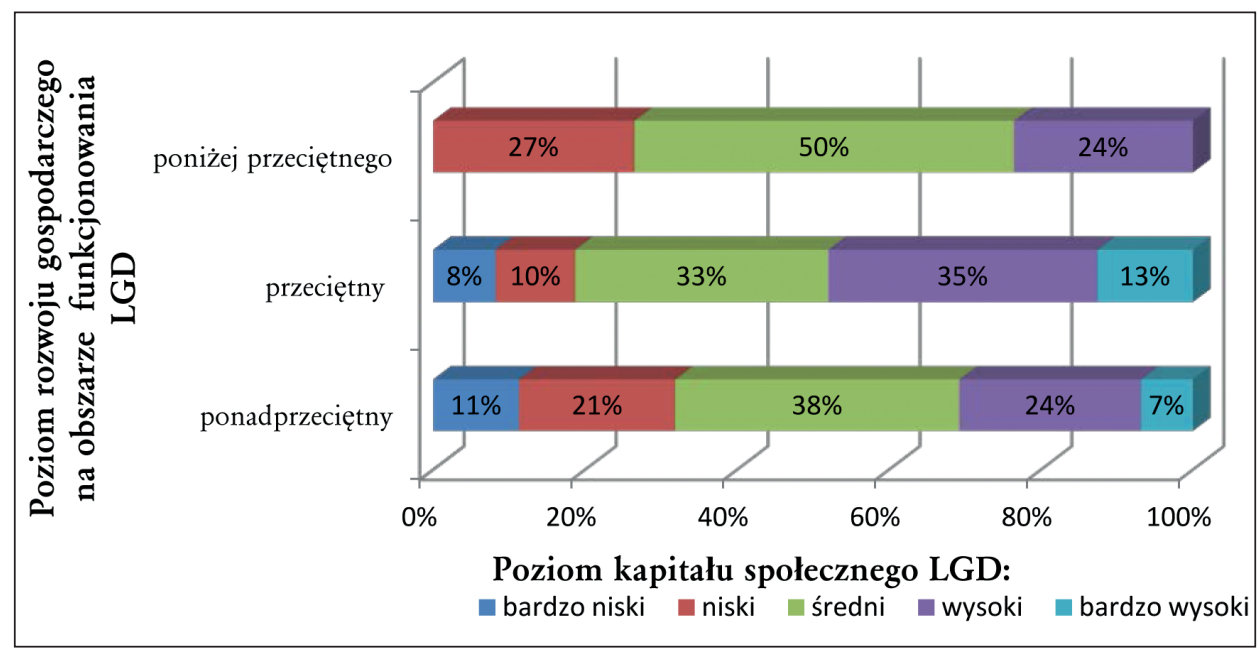

Źródło: opracowanie własne.

Przypuszczenie, że wyższy poziom rozwoju gospodarczego generuje wyższy poziom kapitału społecznego nie zostało potwierdzone wynikami przeprowadzonych analiz. Być może zbyt wysoki poziom rozwoju gospodarczego nie pobudza motywacji do podejmowania działań służących zmianom. Jednocześnie jednak okazuje się, iż jego zbyt niski poziom nie stwarza wystarczających warunków do realizacji takich działań (deklarowane normy i wartości nie wynikają z zaufania i nie znajdują przełożenia na działania).

\subsection{Poziom aktywności społecznej na obszarze partnerstw terytorialnych a poziom kapitału społecznego LGD}

Hipotezę dotyczącą związku pomiędzy aktywnością społeczną mieszkańców gmin wchodzących w skład badanych partnerstw a poziomem kapitału społecznego członków lokalnych grup działania, funkcjonujących na rzecz tychże partnerstw zamierzano zweryfikować w oparciu o wskaźniki, za pomocą których starano się uchwycić specyficzne oblicze tzw. trzeciego sektora na wsi (tj. zarówno działalność tradycyjnych zrzeszeń, takich jak koła gospodyń wiejskich) oraz organizacji nowego typu, czyli fundacji, stowarzyszeń i ich związków. Uwzględnione wskaźniki zostaną omówione w podrozdziałach 4.4.1-4.4.3. 


\subsubsection{Liczba aktywnych KGW i innych tradycyjnych form współpracy mieszkańców wsi na obszarze partnerstw w 2010 r. ${ }^{13}$}

Poddane analizie partnerstwa charakteryzowały się dość zróżnicowanym poziomem aktywności społecznej, wyrażającej się w działalności kół gospodyń wiejskich oraz ochotniczych straży pożarnych. Na obszarze niektórych z nich (LGD Dunajec - Biała i Dolina Karpia z województwa podkarpackiego oraz Fundacja Zielonej Odry i Warty z województwa lubuskiego i Dolina Stobrawy z województwa opolskiego) funkcjonowało zaledwie po kilka-kilkanaście organizacji każdego z wymienionych typów, na obszarze innych (obie grupy z województwa wielkopolskiego, Fundacja Porozumienie Wzgórz Dałkowskich z województwa lubuskiego czy Lider Pojezierza z zachodniopomorskiego) odnotowano aktywność nawet ponad 50. takich podmiotów. Nie należy jednak zapominać o zróżnicowanej liczbie gmin, objętych działaniami poszczególnych LGD. Biorąc pod uwagę średnią liczbę wspomnianych form tradycyjnej współpracy mieszkańców na terenie gmin każdego z partnerstw, można zaobserwować, iż na większości obszarów, na których sieć lokalnych grup była liczniejsza (zbiór II) funkcjonowało także więcej organizacji typu KGW i OSP (z sytuacją taką mamy do czynienia w przypadku obu partnerstw z województwa wielkopolskiego, większości partnerstw z województwa podkarpackiego - wyjątek stanowi Partnerstwo dla Ziemi Niżańskiej oraz LGD PROKOPARA z województwa małopolskiego). Jednocześnie nie sposób nie zauważyć, iż partnerstwa, w których działała największa liczba kół gospodyń wiejskich oraz ochotniczych straży pożarnych były zlokalizowane zarówno na terenach charakteryzujących się największą liczbą LGD (co zaprezentowano powyżej), jak i funkcjonujących na terenach o najmniejszej ich liczbie (jak np. w przypadku LGD Regionu Kozła z województwa lubuskiego czy Partnerstwa Borów Niemodlińskich i Doliny Stobrawy z województwa

${ }^{13}$ Danych zastanych nie można było pozyskać z lokalnych strategii rozwoju (czyli dokumentów strategicznych LGD). Jeśli zawierały one informacje o liczbie aktywnych KGW oraz innych form tradycyjnej współpracy na obszarze partnerstw (czyli wszystkich gmin zrzeszonych w lokalnych grupach działaniach) oraz o liczbie organizacji pozarządowych nowego typu (w tym stowarzyszeń zwykłych) funkcjonujących na ich obszarze, to najczęściej pochodziły one sprzed $2008 \mathrm{r}$. (LSR w tej części nie są najczęściej aktualizowane). W związku z powyższym liczbę aktywnych ochotniczych strażach pożarnych oszacowano na podstawie informacji od urzędów poszczególnych gmin. Starano się również pozyskać od nich informację na temat liczby aktywnych stowarzyszeń zwykłych. Jednak urzędy gmin nie są zobowiązane do ich ewidencji, w związku z czym odnotowano bardzo wiele braków danych w wypełnianych przez sekretarzy gmin kartach opisu aktywności społecznej na obszarze jednostek samorządu terytorialnego. Stwierdzono, iż w przypadku, kiedy odpowiedź była przez nich udzielana, często opierała się na subiektywnych danych pochodzących raczej z ich doświadczeń, niż na jakichkolwiek rejestrach. W związku z powyższym w analizach skoncentrowano się wyłącznie na danych z Banku Danych Lokalnych. 
opolskiego). Wydaje się, że podobnie jak miało to miejsce w przypadku analizowanych we wcześniejszym rozdziale wymiarów sfery gospodarczej, także w odniesieniu do uwarunkowań sfery społecznej mamy do czynienia z większymi niż między kategoriami zróżnicowaniami wewnątrz wyróżnionych kategorii (zbiorów LGD funkcjonujących na terenach o najbardziej i najmniej licznej sieci tego typu organizacji) [por. tabela 56].

\subsubsection{Liczba funkcjonujących na obszarze partnerstw aktywnych organizacji pozarządowych nowego typu oraz stowarzyszeń zwykłych w 2010 r. ${ }^{14}$}

Nieco inne prawidłowości zaobserwowano w przypadku liczby organizacji pozarządowych, stowarzyszeń i fundacji działających na terenie badanych partnerstw. Informacje na temat liczby i charakteru organizacji działających na obszarach analizowanych partnerstw starano się pozyskać nie tylko ze źródeł zastanych, lecz także od badanych członków LGD. Osoby należące do grup zakwalifikowanych do obu zbiorów wśród organizacji działających na terenach objętych działaniami grupy wymieniły przede wszystkim, częściowo wcześniej analizowane, organizacje o charakterze ratowniczym, takie jak OSP czy GOPR oraz koła gospodyń wiejskich, a następnie organizacje sportowe, oświatowe, artystyczne i religijne.

$\mathrm{Na}$ aktywność wszystkich wymienionych typów organizacji na obszarze funkcjonowania własnej LGD zwrócił uwagę większy odsetek badanych z grup należących do zbioru II (od 65\% grupy w przypadku organizacji typu OSP/GOPR oraz KGW do 55\% grupy w przypadku organizacji kościelnych, religijnych) niż badanych ze zbioru I (odpowiednio od 55\% grupy w przypadku organizacji typu OSP/GOPR do 47\% grupy w przypadku organizacji kościelnych, religijnych). Ponad $40 \%$ członków LGD z obu zbiorów wymieniło także organizacje hobbystyczne, charytatywne, zrzeszające osoby z określonej grupy wiekowej (seniorów, młodzież) oraz partie i stowarzyszenia polityczne [por. tabela 55].

${ }^{14}$ Dane pozyskiwano z Banku Danych Lokalnych, uwzględniającego liczbę stowarzyszeń i innych organizacji społecznych zarejestrowanych w systemie REGON (w tym liczbę stowarzyszeń zwykłych, które podlegają rejestracji w starostwach powiatowych i są zobowiązane do ewidencji w systemie REGON). Bank ten pozwala również na określenie liczby fundacji na obszarze każdej $\mathrm{z}$ gmin należących do badanych partnerstw. 
Tabela 55. Rodzaje organizacji funkcjonujących na obszarze badanych partnerstw według deklaracji członków LGD

\begin{tabular}{|c|c|c|}
\hline \multirow[t]{2}{*}{ Typy organizacji } & \multicolumn{2}{|c|}{$\begin{array}{l}\text { Odsetek badanych dekla- } \\
\text { rujących, że na terenie ich } \\
\text { gminy funkcjonuje dana } \\
\text { organizacja }\end{array}$} \\
\hline & $\begin{array}{c}\text { zbiór I } \\
\mathrm{N}=103\end{array}$ & $\begin{array}{l}\text { zbiór II } \\
\mathrm{N}=184\end{array}$ \\
\hline $\begin{array}{l}\text { Ochotnicza Straż Pożarna, Górskie Ochotnicze Pogotowie } \\
\text { Ratunkowe itp. }\end{array}$ & 55 & 65 \\
\hline Organizacje, kluby i stowarzyszenia sportowe & 52 & 61 \\
\hline $\begin{array}{l}\text { Organizacje działające na rzecz szkolnictwa, oświaty, np. komitet rodzi- } \\
\text { cielski, rada rodziców, fundacja szkolna itp. }\end{array}$ & 51 & 63 \\
\hline $\begin{array}{l}\text { Organizacje, stowarzyszenia artystyczne, np. chór, orkiestra, zespół } \\
\text { taneczny, teatralny }\end{array}$ & 51 & 64 \\
\hline Organizacje kobiece, np. koła gospodyń wiejskich & 48 & 65 \\
\hline Organizacje, ruchy religijne, kościelne, wspólnoty parafialne & 47 & 55 \\
\hline $\begin{array}{l}\text { Stowarzyszenia, związki działkowiczów, hodowców, wędkarzy, zbieraczy, } \\
\text { kolekcjonerów, hobbystów }\end{array}$ & 47 & 41 \\
\hline Partie lub stowarzyszenia polityczne & 45 & 45 \\
\hline Organizacje emerytów, kluby seniorów & 44 & 43 \\
\hline Organizacje charytatywne, działające na rzecz potrzebujących dzieci & 42 & 41 \\
\hline Organizacje młodzieżowe, np. harcerstwo, kluby młodzieżowe & 39 & 41 \\
\hline $\begin{array}{l}\text { Organizacje charytatywne, działające na rzecz potrzebujących - starych, } \\
\text { ubogich, chorych, ofiar klęsk żywiołowych itp. }\end{array}$ & 34 & 29 \\
\hline Organizacje, stowarzyszenia turystyczne & 33 & 27 \\
\hline $\begin{array}{l}\text { Stowarzyszenia miłośników regionu, np. zajmujące się ochroną zabyt- } \\
\text { ków, rozwojem kultury regionalnej itp. }\end{array}$ & 33 & 45 \\
\hline $\begin{array}{l}\text { Organizacje samopomocowe, kluby wsparcia, np. stowarzyszenia osób } \\
\text { niepełnosprawnych, samotnych matek, osób bezrobotnych itp. }\end{array}$ & 27 & 21 \\
\hline Organizacje działające na rzecz ochrony środowiska naturalnego & 25 & 20 \\
\hline $\begin{array}{l}\text { Komitety starające się o załatwienie jakiejś konkretnej sprawy (np. wy- } \\
\text { wozu śmieci, budowy drogi), grupy protestu }\end{array}$ & 22 & 20 \\
\hline Towarzystwa przyjaźni z innymi krajami, narodami & 15 & 20 \\
\hline Inne organizacje, stowarzyszenia, ruchy, kluby lub fundacje & 23 & 28 \\
\hline
\end{tabular}

Źródło: opracowanie własne. 
Większy odsetek badanych ze zbioru II wskazujących w swoim otoczeniu aktywne organizacje pozarządowe nie znalazł jednak odzwierciedlenia w informacjach pozyskanych z Banku Danych Lokalnych.

Wstępna analiza danych zastanych wykazała, że więcej podmiotów opisanego typu funkcjonuje na obszarach pokrytych mniej liczną siecią lokalnych grup działania. Aktywność stosunkowo największej liczby organizacji społecznych (co najmniej 120 stowarzyszeń, fundacji itp.) odnotowano na obszarze pięciu z dziewięciu partnerstw, należących do zbioru I (Fundacja Porozumienie Wzgórz Dałkowskich z województwa lubuskiego, Partnerstwo Borów Niemodlińskich i EURO COUNTRY z województwa opolskiego oraz Lider Pojezierza i Środkowopomorska LGD z województwa zachodniopomorskiego) i tylko dwóch partnerstw (z województwa wielkopolskiego), należących do zbioru II (LGD z terenów charakteryzujących się najbardziej liczną siecią lokalnych grup działania). Jednakże uwzględnienie struktury porównywanych obszarów (liczby gmin wchodzących w ich skład) prowadzi do analogicznego wniosku, jak ten sformułowany $w$ odniesieniu do liczby KGW i OSP. Zestawienie średnich liczb organizacji społecznych (stowarzyszeń, fundacji) funkcjonujących na obszarze każdej z gmin poszczególnych partnerstw pokazuje, iż mamy do czynienia z większymi różnicami w zakresie analizowanej zmiennej wewnątrz wyodrębnionych zbiorów niż pomiędzy nimi [por. tabela 56].

\subsubsection{Dynamika przyrostu lokalnych grup działania w województwie ${ }^{15}$}

Przed rokiem 2007 w województwach, z których rekrutowały się badane LGD funkcjonowało 59 organizacji tego typu (łącznie 45 w województwach wielkopolskim, małopolskim i podkarpackim oraz łącznie $14 \mathrm{w}$ województwach lubuskim, opolskim i zachodniopomorskim). W latach 2007-2012 na badanych obszarach pojawiło się ponad dwukrotnie więcej (138) nowych lokalnych grup. Analizując liczby bezwzględne, można stwierdzić, iż zdecydowanie więcej grup powstawało na obszarach już wcześniej charakteryzujących się liczniejszą ich siecią. Jednak biorąc pod uwagę relację liczby organizacji istniejących przed rokiem 2007 do liczby nowych podmiotów tego typu powstałych w latach 2007-2012, większą dynamiką w tym zakresie wydają się charakteryzować województwa o najmniejszej wyjściowej liczbie LGD ${ }^{16}$ [por. tabela 56].

15 Porównywano liczbę LGD, które zawarły umowę o realizację schematu II PPL+ z FAPA oraz liczbę LGD, które podpisały umowy z urzędami marszałkowskimi o realizację osi 4 Programu Rozwoju Obszarów Wiejskich na lata 2007-2013.

${ }^{16}$ Być może większy przyrost liczby LGD jest związany z większymi możliwościami pozyskania środków na ich funkcjonowanie na obszarach, na których konkurencja była mniejsza. 


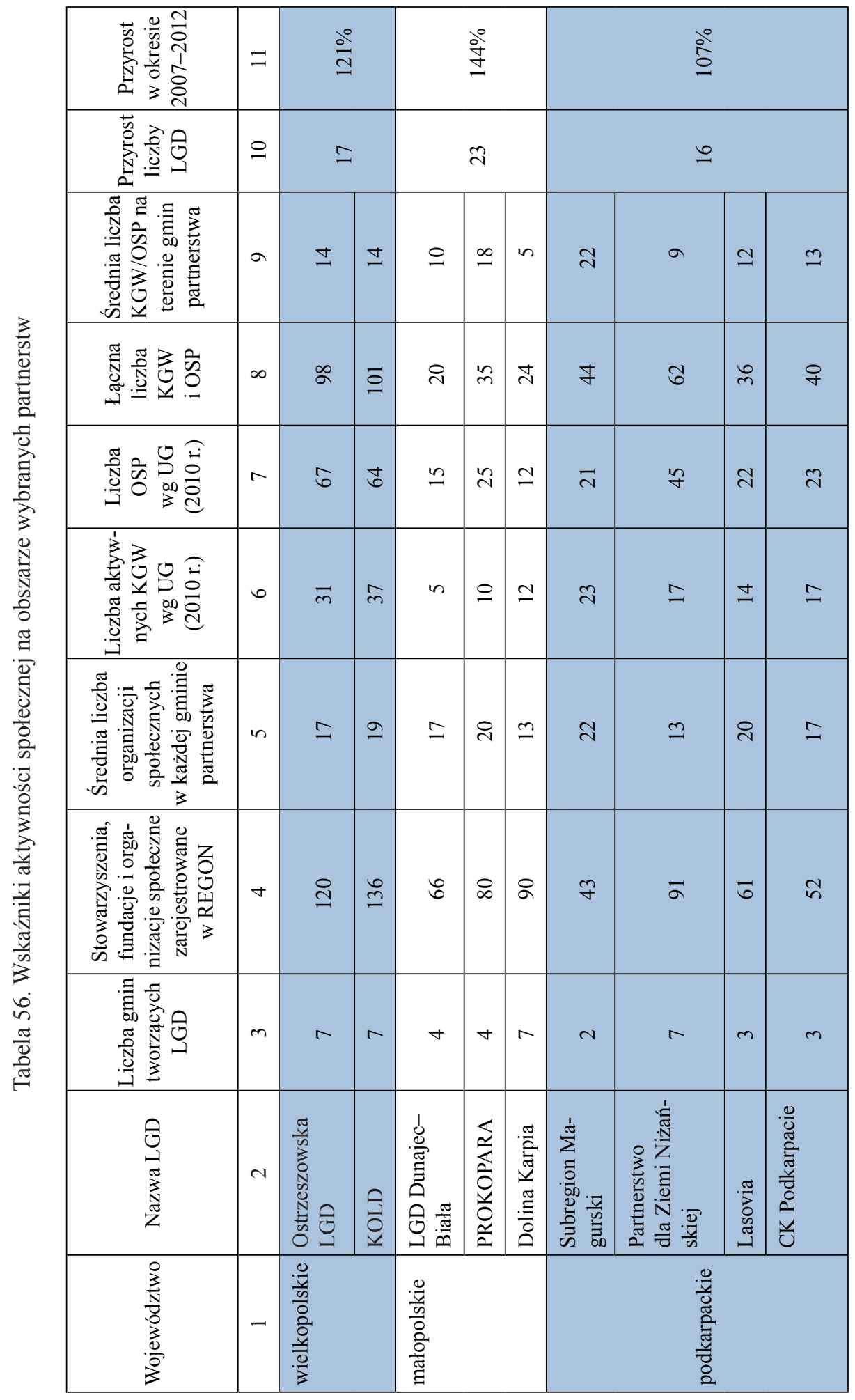




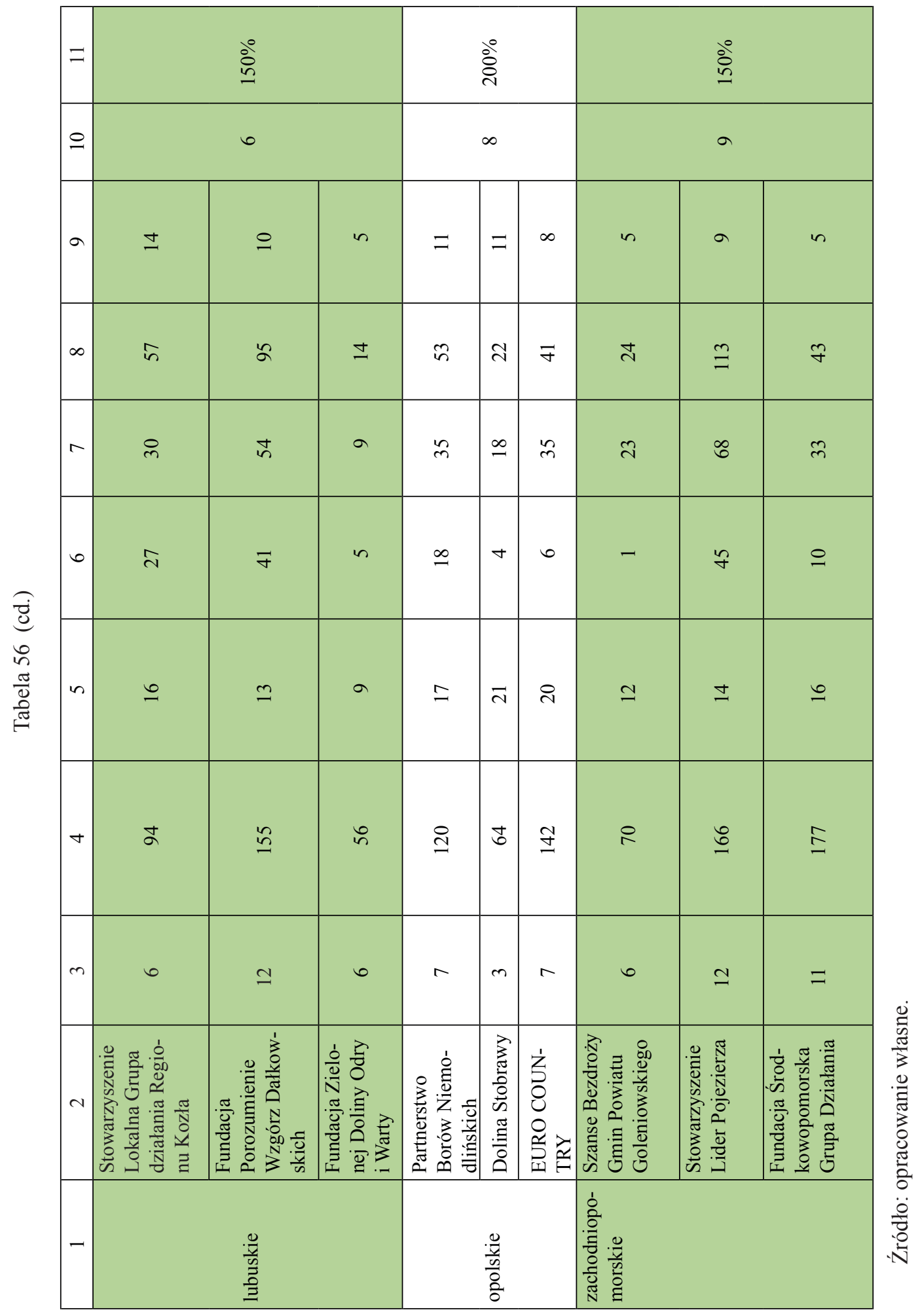


Większa dynamika przyrostu LGD na obszarach, na których przed rokiem 2007 funkcjonowało ich najmniej, idzie w parze ze stwierdzonym wcześniej wyższym poziomem kapitału społecznego członków grup działających na rzecz tych obszarów. Czy zatem jest tak, że tam, gdzie istnieją korzystniejsze warunki powoływania i funkcjonowania lokalnych grup działania (i być może organizacji społecznych w ogóle), w związku z czym powstaje ich więcej (i w ich aktywność siłą rzeczy włączana jest większa liczba mieszkańców obszaru partnerstwa, na rzecz którego działają), wzrasta poziom kapitału społecznego ich członków? Czy też, być może, interpretacja powinna być odwrotna - wyższy kapitał społeczny członków funkcjonujących LGD generuje nowe zasoby takiego kapitału, przekładające się na wyższą aktywność mieszkańców obszaru partnerstwa skanalizowaną w działaniach kolejnych, nowych lokalnych grup?

$\mathrm{Za}$ drugą z przytoczonych interpretacji wydają się przemawiać, zaprezentowane poniżej, rezultaty analizy relacji zachodzących między aktywnością społeczną na obszarze funkcjonowania badanych LGD a poziomem kapitału społecznego ich członków.

Ze względu na zaprezentowany wcześniej rozkład danych dotyczących liczby organizacji pozarządowych, ochotniczych straży pożarnych oraz kół gospodyń wiejskich, na terenach objętych działaniami lokalnych grup należących do zbiorów wyróżnionych w oparciu o liczebność sieci LGD, dla zweryfikowania hipotezy mówiącej o związku poziomu aktywności społecznej na terenach objętych działaniami badanych LGD a poziomem kapitału społecznego ich członków, badaną zbiorowość podzielono na trzy nowe kategorie. Każda z nich charakteryzowała się odmiennym poziomem obu analizowanych wskaźników aktywności społecznej (średnią liczbą organizacji społecznych typu stowarzyszenia, fundacje oraz średnią liczbą OSP/KGW funkcjonujących na obszarze poszczególnych gmin wchodzących w skład partnerstw). Do pierwszej kategorii zaliczono LGD działające na obszarach, w przypadku których co najmniej jeden wskaźnik osiągnął wartość ponadprzeciętną ${ }^{17}$, a drugi co najmniej wartość przeciętną (PROKOPARA z województwa małopolskiego, Subregion Magurski i Lasovia z województwa podkarpackiego, Dolina Stobrawy i EURO COUNTRY z województwa opolskiego), grupy funkcjonujące na obszarach, w przypadku których obydwa wskaźniki uzyskały wartość przeciętną (oba partnerstwa z województwa wielkopolskiego, LGD Dunajec - Biała z województwa małopolskiego, Partnerstwo dla Ziemi Niżańskiej i CK Podkarpacie z województwa podkarpackiego, Partnerstwo Borów Niemodlińskich z województwa opolskiego, LGD Regionu Kozła z województwa lubuskiego) oraz grupy, w przypadku których co najmniej jeden ze wskaźników osiągnął wartość poniżej przeciętnej, zaś drugi co najwyżej wartość przeciętną (Dolina Karpia z województwa małopolskiego,

${ }^{17} \mathrm{~W}$ ramach każdego z analizowanych wymiarów wyróżniono trzy przedziały wartości. Podstawą do ich wyznaczenia była średnia uzyskiwana w danym wymiarze dla całej badanej grupy (18 partnerstw). 
wszystkie partnerstwa z województwa zachodniopomorskiego, Fundacja Zielonej Odry i Warty oraz Porozumienie Wzgórz Dałkowskich z województwa lubuskiego). W wyniku przeprowadzenia podziału uzyskano następującą strukturę próby:

- partnerstwa funkcjonujące na obszarach charakteryzujących się ponadprzeciętnym poziomem aktywności społecznej - 5 (łącznie 50 członków);

- partnerstwa funkcjonujące na obszarach charakteryzujących się przeciętnym poziomem aktywności społecznej - 7 (łącznie 154 członków);

- partnerstwa funkcjonujące na obszarach charakteryzujących się poziomem aktywności społecznej niższym od przeciętnego - 6 (łącznie 83 członków).

Zestawienie średnich wartości syntetycznego wskaźnika kapitału społecznego (oraz średnich wartości wszystkich jego komponentów) osiągniętych przez członków lokalnych grup działania, które weszły w skład każdej z wyróżnionych kategorii, uwidoczniło negatywną zależność między poziomem aktywności społecznej (rozumianej jako liczba organizacji społecznych różnego typu) na obszarze objętym działalnością LGD a poziomem kapitału społecznego ich członków. Najniższą, w porównaniu do pozostałych kategorii grup, średnią wartość wskaźnika kapitału społecznego (11,62 punktu w skali 0-18 punktów), a także relatywnie najniższe wartości jego składowych - komponentów: norm i wartości (średnio 4,56 punktu w skali 0-6 punktów) oraz sieci (średnio 3,05 punktu w skali 0-6 punktów) odnotowano wśród członków grup funkcjonujących na obszarach, na których zarejestrowano stosunkowo największą liczbę organizacji społecznych (stowarzyszeń, fundacji, ochotniczych straży pożarnych i kół gospodyń wiejskich). Z kolei wartości najwyższe, zarówno wskaźnika kapitału społecznego (średnio 13,37 punktu w skali 0-18 punktów), jak i wszystkich jego komponentów składowych: zaufania (średnio 4,14 punktu w skali 0-6 punktów), norm i wartość (średnio aż 5,06 punktu w skali 0-6 punktów) oraz sieci (średnio 3,98 punktu w skali 0-6 punktów) zaobserwowano w grupach aktywnych na terenach cechujących się stosunkowo najmniejszą liczbą działających organizacji społecznych. Co ciekawe, największa różnica między wyodrębnionymi, ze względu na poziom aktywności społecznej na obszarze ich działania, kategoriami LGD pojawiła się w ramach komponentu sieci [por. tabela 57].

Oznaczałoby to, że wysoki poziom kapitału społecznego członków grup zlokalizowanych na obszarach o stosunkowo niskim poziomie aktywności społecznej wynika przede wszystkim z ich rzeczywistego zaangażowania $\mathrm{w}$ działania na rzecz partnerstwa (choć, jak zasygnalizowano powyżej, średni poziom wszystkich komponentów kapitału społecznego jest najwyższy właśnie w tych grupach). Być może uzyskany rezultat wiąże się z koniecznością włożenia większego wysiłku w pracę na rzecz obszaru, którego mieszkańcy nie są szczególnie skłonni do podejmowania jakichkolwiek działań, do czego konieczne są szczególne predyspozycje. Być może osoby angażujące się w prace organizacji działających na terenach charakteryzujących się mniej sprzyjającą atmosferą do podejmowania 
aktywności społecznej już na starcie charakteryzują się ponadprzeciętnym poziomem kapitału społecznego, wyrażającym się w ich stosunkowo wysokim zaufaniu społecznym oraz przekonaniu o konieczności i sensowności podejmowania działań na jej rzecz, za którym takie właśnie działania idą.

Tabela 57. Poziom komponentów kapitału społecznego w LGD funkcjonujących na obszarach o różnym poziomie aktywności społecznej

\begin{tabular}{|c|c|c|c|}
\hline \multirow[b]{2}{*}{$\begin{array}{l}\text { Komponenty kapitału } \\
\text { społecznego }\end{array}$} & \multicolumn{3}{|c|}{$\begin{array}{l}\text { Średnie wartości komponentów kapitału społecznego LGD } \\
\text { z obszarów charakteryzujących się: }\end{array}$} \\
\hline & $\begin{array}{l}\text { ponadprzeciętnym } \\
\text { poziomem aktyw- } \\
\text { ności społecznej }\end{array}$ & $\begin{array}{c}\text { przeciętnym pozio- } \\
\text { mem aktywności } \\
\text { społecznej }\end{array}$ & $\begin{array}{l}\text { niższym od przeciętne- } \\
\text { go poziomem aktyw- } \\
\text { ności społecznej }\end{array}$ \\
\hline Zaufanie (0-6) & 4,00 & 3,88 & 4,14 \\
\hline do osób znanych (0-2) & 1,66 & 1,53 & 1,66 \\
\hline społeczne (0-2) & 0,99 & 1,11 & 1,12 \\
\hline do instytucji (0-2) & 1,33 & 1,69 & 1,27 \\
\hline Normy i wartości (0-6) & 4,56 & 4,79 & 5,06 \\
\hline patriotyzm lokalny $(0-2)$ & 1,57 & 1,79 & 1,79 \\
\hline $\begin{array}{l}\text { normy i wartości związane } \\
\text { z uczestnictwem w LGD }(0-2)\end{array}$ & 1,54 & 1,47 & 1,62 \\
\hline normy społeczne (0-2) & 1,42 & 1,53 & 1,65 \\
\hline Sieci (0-6) & 3,05 & 3,30 & 3,98 \\
\hline $\begin{array}{l}\text { sieci współpracy na rzecz part- } \\
\text { nerstwa lub gminy }(0-2)\end{array}$ & 0,76 & 1,18 & 1,38 \\
\hline $\begin{array}{l}\text { uczestnictwo w pracach LGD } \\
(0-2)\end{array}$ & 0,96 & 1,04 & 1,31 \\
\hline $\begin{array}{l}\text { poczucie wpływu na funkcjono- } \\
\text { wanie partnerstwa }(0-2)\end{array}$ & 1,18 & 1,11 & 1,29 \\
\hline $\begin{array}{l}\text { Kapitał społeczny - suma kom- } \\
\text { ponentów }(0-18)\end{array}$ & 11,62 & 11,91 & 13,37 \\
\hline
\end{tabular}

Źródło: opracowanie własne.

W tym miejscu warto zwrócić uwagę na wskaźnik zaufania do instytucji lokalnych, jedyny, którego wartość w omawianej grupie jest niższa, niż ma to miejsce w pozostałych kategoriach grup. Zaobserwowana sytuacja zdaje się potwierdzać przypuszczenie o mniej sprzyjających warunkach funkcjonowania LGD, a być może organizacji społecznych w ogóle na omawianych obszarach. 
A zatem, uzyskane dane, choć nie uprawniają do odrzucenia hipotezy mówiącej, iż im wyższy jest poziom aktywności społecznej na danym obszarze, tym wyższy jest także poziom kapitału społecznego członków organizacji działających na jego rzecz, dają jednak solidną podstawę do podania jej w wątpliwość i postawienia hipotezy mówiącej o istnieniu między badanymi zmiennymi zależności o przeciwnym kierunku. Oczywiście prawdziwość takiej hipotezy należałoby sprawdzić w oparciu o dane o bardziej systematycznym charakterze.

\subsection{Poziom współpracy międzysektorowej na obszarze partnerstw terytorialnych a poziom kapitału społecznego LGD}

Ostatni typ uwarunkowań kapitału społecznego LGD, który wzięto pod uwagę w realizowanym projekcie, był związany z zakresem współpracy sektora społecznego, publicznego i gospodarczego na obszarze funkcjonowania badanych grup. Czynniki składowe zostaną omówione w podrozdziałach 4.5.1-4.5.2.

\subsubsection{Przywództwo lokalne i autorytet władzy lokalnej}

Początkowo, na etapie redagowania wniosku o dofinansowanie projektu i przygotowywania jego koncepcji badawczej zakładano szczegółową identyfikację formalnych i nieformalnych liderów rozwoju wsi oraz jakościową analizę ich roli w inicjowaniu działań na rzecz współpracy międzysektorowej na obszarze partnerstwa. Spowodowana względami finansowymi rezygnacja z części jakościowej badania oraz opisane wcześniej problemy z realizacją części ilościowej (zwłaszcza niechęć do ujawniania jakichkolwiek danych personalnych członków LGD) spowodowały, że ten wymiar uwarunkowań ograniczono do zbadania poczucia wpływu respondentów na decyzje władz lokalnych. Interesujące było także określenie, czy przywództwo lokalne jest na tyle silne, że członkowie LGD nie są zainteresowani konkurowaniem z obecną władzą w wyborach lokalnych, czy też zamierzali brać w nich udział, dążąc do zmiany lokalnego układu politycznego. Respondentów pytano także o to, czy chcieliby coś zmienić w sposobie funkcjonowania władzy lokalnej.

Okazało się, że poziom kapitału społecznego członków LGD wiąże się z ich przekonaniami na temat władzy lokalnej. Relatywnie wyższym poziomem kapitału cechują się osoby, które krytycznie oceniają działania władz lokalnych, zauważając potrzebę wprowadzenia zmian w ich funkcjonowanie, mają wyższe poczucie wpływu na decyzje władz oraz same rozważają możliwość objęcia wysokiego urzędu lokalnej administracji [por. tabela 58]. 
Tabela 58. Stosunek do władz lokalnych a poziom kapitału społecznego członków LGD

\begin{tabular}{|l|l|c|c|c|c|}
\hline \multicolumn{2}{|c|}{ Stosunek do władz lokalnych: } & Zaufanie & $\begin{array}{c}\text { Normy } \\
\text { i wartości }\end{array}$ & Sieci & $\begin{array}{c}\text { Suma kom- } \\
\text { ponentów }\end{array}$ \\
\hline $\begin{array}{l}\text { Przekonanie o potrzebie } \\
\text { wprowadzenia zmian } \\
\text { w funkcjonowanie władzy } \\
\text { lokalnej }\end{array}$ & tak n = 102 & 3,93 & 4,80 & 3,61 & 12,36 \\
\cline { 2 - 6 } & nie n = 169 & 3,99 & 4,75 & 3,27 & 12,00 \\
\hline \multirow{2}{*}{$\begin{array}{l}\text { Zamiar objęcia funkcji } \\
\text { wójta/burmistrza }\end{array}$} & tak n = 55 & 4,17 & 5,11 & 4,07 & 13,24 \\
\cline { 2 - 6 } & nie n = 217 & 3,91 & 4,67 & 3,21 & 11,84 \\
\hline \multirow{2}{*}{$\begin{array}{l}\text { Poczucie wpływu } \\
\text { na decyzje władz lokal- } \\
\text { nych }\end{array}$} & $\begin{array}{l}\text { bardzo duży } \\
\text { wpływ n }=31\end{array}$ & 4,41 & 5,26 & 4,38 & 14,59 \\
\cline { 2 - 6 } & $\begin{array}{l}\text { raczej duży } \\
\text { wpływ n }=44\end{array}$ & 4,17 & 5,05 & 3,73 & 13,03 \\
\cline { 2 - 6 } & $\begin{array}{l}\text { przeciętny } \\
\text { wpływ n }=82\end{array}$ & 4,06 & 4,64 & 3,27 & 11,95 \\
\cline { 2 - 6 } & $\begin{array}{l}\text { raczej mały } \\
\text { wpływ n }=29\end{array}$ & 3,27 & 5,00 & 2,96 & 11,18 \\
\hline & $\begin{array}{l}\text { brak wpływu } \\
\text { n=4 }\end{array}$ & 3,50 & 3,75 & 2,00 & 9,25 \\
\hline
\end{tabular}

Źródło: opracowanie własne.

Czy zatem jest tak, że kształtowaniu wysokiego poziomu kapitału społecznego członków LGD sprzyja niski poziom przywództwa lokalnego? Być może w sytuacji, gdy władze samorządowe działają w sposób, który nie spełnia oczekiwań osób w imieniu i na rzecz których powinny pracować, osoby te zyskują wyższą motywację do podjęcia działań służących zmianom. Być może między innymi również dlatego przystępują do organizacji umożliwiających im realizację takich działań. Co najmniej równie prawdopodobna wydaje się jednak hipoteza mówiąca, iż osoby cechujące się wyższym poziomem kapitału społecznego oraz wyższymi aspiracjami (również w zakresie pełnienia wysokich funkcji w lokalnym samorządzie) są bardziej skłonne do krytycznej oceny działań prowadzonych przez władze lokalne (zapewne niejednokrotnie personalnych rywali do objęcia stanowiska wójta/burmistrza). Niejako z założenia, mając wyższe poczucie wpływu na decyzje władz (wynikające być może także z zakresu działań realizowanych w ramach LGD), są one mniej skłonne do traktowania przedstawicieli władz, z którymi niejednokrotnie prawdopodobnie stykają się w codziennych sytuacjach, jako autorytetów. Warto zaznaczyć, że w wielu przypadkach nie musi to być sytuacja negatywna. Bardziej świadomi obywatele, skłonni do działania na rzecz realizacji zarówno własnych, jak i wspólnych interesów mieszkańców gminy, kompetentni do oceny działań podejmowanych przez władze, mogą pozytywnie stymulować wzrost poziomu lokalnego przywództwa. 


\subsubsection{Różne wymiary współpracy międzysektorowej na obszarze partnerstwa}

Dla każdego z badanych partnerstw zamierzano obliczyć wartości trzech wskaźników określających poziom współpracy między poszczególnymi sektora$\mathrm{mi}^{18}$. Pierwszy z nich dotyczył wymiaru formalnoprawnego współpracy trójsektorowej. Tu poszukiwano informacji na temat: a) planów współpracy urzędów gmin z organizacjami pozarządowymi, b) projektów realizowanych przez jednostki samorządu terytorialnego (w okresie 2007-2013) na rzecz wsparcia lokalnych przedsiębiorców, c) uproszczeń zastosowanych w urzędach gmin w zakresie obsługi osób fizycznych prowadzących działalność gospodarczą lub osób, które dopiero rejestrują działalność. Dodatkowo analizowano lokalne strategie rozwoju, wyodrębniając w ich ramach zapisy dotyczące celów związanych ze współpracą trzech sektorów.

Drugi wskaźnik miał się odnosić do przepływów finansowych w relacjach trzech sektorów. Poszukiwano informacji na temat wsparcia finansowego udzielanego przez:

a) gminy organizacjom pozarządowym,

b) przedsiębiorców gminom,

c) przedsiębiorców organizacjom pozarządowym.

Trzecim wskaźnikiem zamierzano opisać wymiar współpracy trzech sektorów związany z interakcjami zachodzącymi między nimi. Dążono do ustalenia, czy na obszarze gmin zrzeszonych we wszystkich badanych partnerstwach odbywały się spotkania poświęcone: a) współpracy władzy lokalnej z przedsiębiorcami, b) współpracy władzy lokalnej z organizacjami pozarządowymi, c) współpracy przedsiębiorców z organizacjami pozarządowymi.

W obliczu braku źródeł zastanych dotyczących współpracy trójsektorowej na obszarze partnerstw zdecydowano się na pozyskanie danych na jej temat z urzędów poszczególnych gmin wchodzących w ich skład. Procedurę pozyskiwania danych podzielono na dwa etapy. W pierwszym kontaktowano się z sekretarzami gmin, osobami odpowiedzialnymi w urzędach za kontakty $\mathrm{z}$ organizacjami pozarządowymi i obsługę przedsiębiorców, prosząc o zapoznanie się z istniejącą dokumentacją na temat współpracy trzech sektorów na obszarze gminy (szczegółowo informując o pytaniach badacza - przesyłając je w formie mailowej lub używając $\mathrm{w}$ tym celu faksu). Po upływie tygodnia ponownie kontaktowano się z respondentami, zadając im przesłane wcześniej pytania dotyczące wskazanych wymiarów współpracy trójsektorowej. Niestety część osób, do których się zwrócono, od-

${ }^{18}$ Podstawowym źródłem danych były wywiady telefoniczne przeprowadzane z pracownikami urzędów gmin wchodzących w skład poszczególnych partnerstw. 
mówiła udzielenia informacji, a część nie dotarła do danych na temat niektórych wymiarów. Szczególnie dużą liczbę braków danych odnotowano w obszarach nie związanych bezpośrednio z działaniami sektora publicznego (interakcji i przepływów finansowych między sektorem gospodarczym i społecznym). W związku z tym wyłączono z dalszych analiz dane dotyczące tych właśnie obszarów. Pod wpływem wstępnej analizy informacji, które udało się pozyskać ${ }^{19}$, zrezygnowano także z pomysłu zbudowania osobnych indeksów obrazujących poziom współpracy w obrębie poszczególnych wymiarów. Ze względu na wątpliwości dotyczące rzetelności niektórych informacji ${ }^{20}$ nie zdecydowano się także na skonstruowanie zbiorczego, syntetycznego indeksu współpracy trójsektorowej. W odniesieniu do wszystkich badanych LGD odnotowano jedynie udział gmin realizujących współpracę międzysektorową ${ }^{21}$ (w ramach wyróżnionych powyżej wymiarów) $\mathrm{w}$ zbiorze wszystkich jednostek samorządowych zrzeszonych w partnerstwie (w kategoriach większość - połowa - mniejszość). Efekty zastosowanej procedury zaprezentowano w tabeli 59.

Na podstawie danych w niej przedstawionych można stwierdzić, iż w zbiorze LGD z terenów, na których funkcjonuje najmniej organizacji tego typu (zbiorze I) nie znalazło się żadne partnerstwo, na terenie większości gmin którego zaobserwowano brak współpracy między sektorem publicznym a sektorami społecznym i gospodarczym $\mathrm{w}$ więcej niż jednym $\mathrm{z}$ analizowanych wymiarów. W zbiorze II (LGD z obszarów pokrytych najliczniejszą siecią organizacji tego typu) znalazły się dwa partnerstwa (Ostrzeszowska LGD i CK Podkarpacie), w przypadku których co najmniej dwa wymiary współpracy realizowano w mniej niż połowie gmin zrzeszonych w partnerstwie [por. tabela 59].

19 Okazało się, że dane dotyczące większości partnerstw (będące wypadkową informacji dotyczących współpracy trójsektorowej na obszarze gmin wchodzących w ich skład) są do siebie bardzo zbliżone.

${ }^{20}$ Dane pozyskiwano od przedstawicieli jednego z badanych sektorów. Zakładano, iż w ramach obszaru interesującego badaczy, będą oni dysponowali dostępem do danych najbardziej pełnych i rzetelnych i zgodzą się na ich przekazanie badaczom. Zgodnie z przyjętym założeniem, niektóre osoby bardzo poważnie podeszły do badania i odszukały w dokumentacji dane dotyczące zagadnień interesujących badaczy. Niestety w większości przypadków dysponowano wyłącznie deklaracjami respondentów. W sytuacji braku możliwości zweryfikowania uzyskanych informacji w oparciu o niezależne, bardziej obiektywne źródła obawiano się, iż uzyskane informacje mogą zawyżać wkład sektora publicznego we współpracę trójsektorową na obszarze gminy lub, w skrajnych przypadkach, w ogóle nie mieć pokrycia w działaniach realizowanych na obszarze partnerstwa.

${ }^{21}$ Uznawano, że współpraca jest realizowana w sytuacji, gdy działania podejmowały nie tylko władze, ale także pozostałe sektory (np.. w wymiarze finansowym - nie tylko władze finansują przedsięwzięcia organizacji pozarządowych, ale przedsiębiorcy wspierają także działania podejmowane przez władze na rzecz mieszkańców partnerstwa np. imprezy, festyny itp.) 
Tabela 59. Współpraca trójsektorowa w badanych partnerstwach

\begin{tabular}{|c|c|c|c|c|c|}
\hline \multirow[t]{2}{*}{ Województwo } & \multirow[t]{2}{*}{ Nazwa LGD } & \multirow[t]{2}{*}{$\begin{array}{r}\text { Liczba gmin } \\
\text { partnerstwa }\end{array}$} & \multicolumn{3}{|c|}{$\begin{array}{l}\text { Proporcje jednostek, w których jest } \\
\text { realizowana współpraca między sektorem } \\
\text { publicznym i pozostałymi sektorami, } \\
\text { w ramach ogółu gmin partnerstwa }\end{array}$} \\
\hline & & & $\begin{array}{l}\text { wymiar } \\
\text { formalny }\end{array}$ & $\begin{array}{l}\text { wymiar } \\
\text { finansowy }\end{array}$ & $\begin{array}{l}\text { wymiar } \\
\text { interakcji }\end{array}$ \\
\hline wielkopolskie & Ostrzeszowska LGD & 7 & mniejszość & mniejszość & połowa \\
\hline wielkopolskie & KOLD & 7 & mniejszość & połowa & większość \\
\hline małopolskie & LGD Dunajec- Biała & 4 & połowa & połowa & większość \\
\hline małopolskie & PROKOPARA & 4 & większość & większosść & większość \\
\hline małopolskie & Dolina Karpia & 7 & większość & większość & większość \\
\hline podkarpackie & Subregion Magurski & 2 & połowa & połowa & połowa \\
\hline podkarpackie & Lasovia & 3 & mniejszość & większosść & mniejszość \\
\hline podkarpackie & CK Podkarpacie & 3 & brak danych & mniejszość & mniejszość \\
\hline podkarpackie & $\begin{array}{l}\text { Partnerstwo dla Ziemi } \\
\text { Niżańskiej }\end{array}$ & 7 & mniejszość & większośśc & mniejszość \\
\hline lubuskie & $\begin{array}{l}\text { Stowarzyszenie LGD } \\
\text { Regionu Kozła }\end{array}$ & 6 & połowa & połowa & połowa \\
\hline lubuskie & $\begin{array}{l}\text { Fund. Porozumienie } \\
\text { Wzgórz Dałkowskich }\end{array}$ & 12 & mniejszość & większośśc & większość \\
\hline lubuskie & $\begin{array}{l}\text { Fund. Zielonej Doliny } \\
\text { Odry i Warty }\end{array}$ & 6 & połowa & połowa & większość \\
\hline opolskie & $\begin{array}{l}\text { Partnerstwo Borów } \\
\text { Niemodlińskich }\end{array}$ & 7 & większość & połowa & mniejszość \\
\hline opolskie & Dolina Stobrawy & 3 & mniejszość & większość & większość \\
\hline opolskie & EURO COUNTRY & 7 & mniejszość & większośść & większość \\
\hline $\begin{array}{l}\text { zachodniopo- } \\
\text { morskie }\end{array}$ & Szan & 6 & mniejszość & połowa & większość \\
\hline $\begin{array}{l}\text { zachodniopo- } \\
\text { morskie }\end{array}$ & $\begin{array}{l}\text { Stowarzyszenie Lider } \\
\text { Pojezierza }\end{array}$ & 12 & mniejszość & większosść & połowa \\
\hline $\begin{array}{l}\text { zachodniopo- } \\
\text { morskie }\end{array}$ & $\begin{array}{l}\text { Fundacja Środkowo- } \\
\text { pomorska GD }\end{array}$ & 11 & większość & większość & większość \\
\hline
\end{tabular}

Źródło: opracowanie własne. 
Jednocześnie jednak właśnie ze zbioru II pochodziły także dwie z trzech LGD, w których współpracę między sektorami we wszystkich trzech analizowanych wymiarach realizowano w większości gmin objętych działaniami badanych organizacji. A zatem, charakter i zakres współpracy trójsektorowej na obszarach objętych wsparciem lokalnych grup działania nie jest związany z liczebnością organizacji tego typu działających na obszarze województwa, w którym partnerstwa te są zlokalizowane.

W związku z tym, podobnie jak miało to miejsce w przypadku analiz służących weryfikacji hipotez dotyczących gospodarczych i społecznych uwarunkowań kapitału społecznego lokalnych grup działania, także próba weryfikacji przypuszczenia o związku między zakresem współpracy trójsektorowej prowadzonej na obszarze badanych LGD z poziomem kapitału społecznego ich członków wymagała dokonania nowego podziału badanej zbiorowości. W ramach każdego z analizowanych wymiarów współpracy międzysektorowej wydzielono grupy, w których taka współpraca była realizowana na terenie większości jednostek samorządowych, wchodzących w skład partnerstwa oraz grupy, w których odnotowano ją na terenie mniej niż połowy gmin objętych wsparciem LGD ${ }^{22}$. Następnie porównano średni poziom kapitału społecznego w obu wyróżnionych kategoriach grup.

Nie zaobserwowano różnicy między poziomem kapitału społecznego członków LGD, w przypadku których w większości gmin realizowano działania związane ze wspólnym finansowaniem przedsięwzięć na rzecz mieszkańców obszaru przez sektory publiczny i gospodarczy, a poziomem kapitału społecznego LGD, w których takie działania odnotowano tylko w pojedynczych gminach partnerstwa. Różnica między średnią wartością kapitału społecznego członków LGD należących do obu zbiorów wynosiła 0,01 punktu w skali od 0 do 18 punktów.

Niewielkie różnice między wyodrębnionymi, ze względu na realizację współpracy międzysektorowej w danym obszarze lub jej brak, kategoriami grup odnotowano w ramach dwóch pozostałych wyodrębnionych wymiarów - interakcji oraz formalnego. W przypadku pierwszego z nich, odnoszącego się do organizacji spotkań, w których uczestniczyli przedstawiciele sektora publicznego oraz przedstawiciele sektorów społecznego i gospodarczego, nieznacznie wyższy średni poziom kapitału społecznego (średnio 12,35 punktu w skali 0-18 punktów) zaobserwowano wśród członków LGD, w przypadku których spotkania takie odbywały się w większości gmin objętych działaniami grupy, niż w przypadku LGD, zrzeszających gminy, w większości których spotkań takich nie organizowano (średnio 11,84 punktu w skali 0-18 punktów).

Z kolei w ramach formalnego wymiaru współpracy trójsektorowej nieco wyższy wynik uzyskały grupy, obejmujące swoimi działaniami gminy, w dokumentacji

22 Ze względu na niewielkie zróżnicowanie poziomu badanej zmiennej, w analizie zdecydowano się pominąc grupy, w których współpraca w ramach danego wymiaru odbywała się na terenie połowy gmin partnerstwa. 
których (w przypadku większości) nie znalazły się zapisy dotyczące wspólnych działań przedstawicieli różnych sektorów (średnio 12,04 punktu w skali 0-18 punktów), niż grupy funkcjonujące na terenie gmin, w dokumentach których (w większości) umieszczono informacje o planach i/lub działaniach związanych ze współpracą trzech sektorów (średnio 11,22 punktu).

Na podstawie uzyskanych rezultatów, pamiętając o ograniczeniach wynikających z charakteru danych źródłowych, można wysnuć ostrożne przypuszczenie, iż zakres współpracy trójsektorowej realizowanej na obszarze gmin objętych wsparciem lokalnych grup działania nie wpływa w sposób znaczący na poziom kapitału społecznego członków LGD. Osiągnięciu jego wysokiego poziomu zdaje się sprzyjać sytuacja, w której na terenie partnerstwa rozpowszechniona jest praktyka odbywania bezpośrednich spotkań przedstawicieli władz, organizacji pozarządowych oraz lokalnych przedsiębiorców, mających na celu podjęcie i/lub realizację wspólnych przedsięwzięć na rzecz mieszkańców obszaru objętego ich funkcjonowaniem. Nie mają wpływu ani zapisy dotyczące współpracy trójsektorowej zamieszczane w dokumentach władz lokalnych, ani też działania związane ze wspólnym finansowaniem różnych przedsięwzięć przez przedstawicieli różnych sektorów. Jednak zauważyć należy, iż nie sposób dotrzeć do dokumentów czy źródeł obiektywnie rejestrujących poziom współpracy trójsektorowej we wszystkich gminach objętych działaniami badanych LGD. W oparciu o uzyskane informacje (mogące być, mimo prośby o sprawdzenie faktów, tylko przypuszczeniami informatorów), w zasadzie nie jest możliwe wskazanie partnerstw, którym można przypisać wyraźną, jednoznaczną charakterystykę wzajemnych relacji przedstawicieli trzech sektorów, pozwalającą na oszacowanie poziomu współpracy między nimi. W konsekwencji w analizowanym zbiorze de facto nie udało się wyróżnić grup funkcjonujących na obszarach istotnie zróżnicowanych pod względem badanej cechy, a co za tym idzie niemożliwe okazało się oszacowanie wpływu zróżnicowanego poziomu tej zmiennej na poziom kapitału społecznego członków badanych LGD. 


\section{ROZDZIAŁ V}

\section{PODSUMOWANIE I WNIOSKI}

Podjętym badaniom towarzyszyły dwa rodzaje przesłanek: naukowe oraz praktyczne, aplikacyjne. Ich autorki, zgodnie z postulatem socjologii refleksyjnej, miały zamiar poddać analizie relatywnie nową (związaną z implementacją podejścia LEADER) rzeczywistość społeczną wsi i w ten sposób zabrać głos w dyskusji dotyczącej istoty kapitału społecznego. Zamierzały również przyczynić się do wzrostu wiedzy członków LGD oraz instytucji odpowiedzialnych za realizację podejścia LEADER w Polsce na temat uwarunkowań jego realizacji, mając na uwadze m.in. fakt, iż połowa LGD nie realizuje żadnych badań poświęconych swojemu działaniu [Raport PSDB 2012: 5].

Przeprowadzone analizy struktury kapitału społecznego lokalnych grup działania, a także wpływu uwarunkowań gospodarczych, społecznych i tych związanych ze współpracą reprezentantów sektora publicznego, społecznego i gospodarczego z obszaru partnerstw na poziom tego kapitału pozwoliły na weryfikację większości hipotez wyznaczających zakres podjętych badań.

Kapitał społeczny członków lokalnych grup działania charakteryzował się stosunkowo wysokim poziomem ogólnym, jednakże (co potwierdza postawione hipotezy) jego struktura okazała się wewnętrznie niespójna. Poszczególne analizowane komponenty (zaufania, norm i wartości, sieci) nie były wzajemnie powiązane (tylko między niektórymi z nich odnotowano słabe zależności), a prezentujące ich poziom syntetyczne wskaźniki osiągnęły znacząco zróżnicowane wartości.

Najwyższym poziomem ze wszystkich badanych komponentów kapitału społecznego członków lokalnych grup działania cechował się wymiar norm i wartości. Większość członków LGD to zdeklarowani społecznicy, gotowi do niesienia pomocy innym i faktycznie $\mathrm{w}$ większości działający $\mathrm{w}$ rozmaitych stowarzyszeniach, organizacjach oraz/lub niezależnie od nich biorący udział w przedsięwzięciach na rzecz lokalnej społeczności. Są to osoby przywiązane do idei partnerstwa jako nowej, spójnej wartości, na rzecz której warto podejmować działania we współpracy z przedstawicielami różnych sektorów (nawet, jeśli nie darzy się ich szczególnie wysokim zaufaniem). Jednocześnie to lokalni patrioci przywiązani do swojego miejsca zamieszkania, gotowi wspierać lokalną kulturę 
własnymi zasobami finansowymi, biorący udział (często istotnie wykraczający poza samo oddanie głosu) w wyborach samorządowych, przekonani o znaczącym wpływie osób im podobnych na losy bezpośredniego otoczenia (gminy, partnerstwa).

Zgodnie z oczekiwaniami, relatywnie najmniej korzystne rezultaty (najniższy poziom wśród badanych komponentów) uzyskano w wymiarze sieci powiązań, łączących członków LGD. Mimo deklaracji dotyczących pełnej akceptacji dla idei partnerstwa jako odrębnej całości, a także idącego za nią zaangażowania, aktywności, faktyczne działania realizowano raczej na rzecz poszczególnych gmin, z którymi związani byli działacze, a nie na rzecz całego obszaru. Aktywnością związaną z realizacją inicjatyw podejmowanych przez LGD wykazywała się już tylko nieco ponad połowa ich członków (przy czym część „niezaangażowanych” miała poczucie wykluczenia z rozmaitych działań i decyzji mimo wykazywanej chęci uczestnictwa).

Członkowie badanych LGD nie różnią się od ogółu Polaków w wymiarze zaufania. Większość z nich cechuje duże zaufanie do osób najbliższych (rodziny, sąsiadów, współpracowników, także tych z LGD, zwłaszcza, jeśli reprezentują ten sam sektor, co respondent) i znacząco niższe zaufanie do nieznajomych, spotykanych w różnych sytuacjach życiowych oraz do instytucji lokalnych. Mimo że uzyskane dane nie odbiegają od przeciętnych wyników ogólnopolskich, w odniesieniu do członków LGD nie napawają optymizmem. W założeniach lokalne grupy miały stanowić stymulatory, swego rodzaju „generatory” zasobów kapitału społecznego obszaru partnerstwa. Wspólna praca przedstawicieli różnych sektorów, przebiegająca $\mathrm{z}$ istotnym współudziałem szerokiego kręgu mieszkańców partnerstwa miała budować zaufanie do tego typu struktur, integrować lokalną społeczność wokół wspólnych interesów, przyczyniać się do budowania nowych sieci relacji, zarówno między mieszkańcami partnerstwa, jak i między ewentualnymi partnerami LGD spoza jego obszaru. Tymczasem wydaje się, że stosunkowo wysoki poziom kapitału społecznego członków lokalnych grup jest pochodną przede wszystkim ich zaufania do najbliższych, norm i wartości związanych z partnerstwem, pozostających w sferze deklaracji oraz nie do końca odzwierciedlających je działań, podejmowanych na rzecz własnej gminy. Nie istnieje przełożenie na zaufanie do osób spoza najbliższego kręgu znajomych i współpracowników, a co za tym idzie - także na rozbudowaną i otwartą na dalsze rozszerzanie sieć kontaktów społecznych. Kapitał społeczny ma raczej charakter kapitału wiążącego, ograniczającego, a nie pomostowego, generującego nowe formy relacji między różnymi aktorami lokalnej społeczności. Tezę taką zdaje się potwierdzać fakt, że w badanej zbiorowości stosunkowo najwyższym poziomem kapitału społecznego cechują się osoby o najkorzystniejszych charakterystykach społeczno-demograficznych (osoby w średnim wieku, mające wykształcenie wyższe i reprezentujące kategorie zawodowe implikujące wysoką pozycję społeczno-ekonomiczną). A zatem, w ramach LGD kapitał społeczny jest pomnażany w przypadku tych osób, które już 
w momencie przystąpienia do struktury cechowały się jego wysokim poziomem. Organizacja wydaje się nie mieć charakteru „kapitałotwórczego” w odniesieniu do dużych grup mieszkańców obszaru partnerstwa, aktywizując i wspierając (budując kapitał) raczej tych jego członków, którzy sami poszukują możliwości zaangażowania posiadanych już zasobów oraz ich pomnożenia.

Podsumowując najważniejsze wyniki badań, należy przypomnieć, że realizowano je na obszarach województw cechujących się największym i najmniejszym nasyceniem LGD (w okresie PPL+). Dokonując analizy porównawczej zbiorów LGD, funkcjonujących na obszarach o różnym nasyceniu organizacjami tego typu wykazano, iż między grupami obejmującymi swoim wsparciem fragmenty województw, w których LGD występują najliczniej (zbiór II) a grupami działającymi na terenie województw, gdzie organizacji tych jest najmniej (zbiór I) - zachodzą różnice w zakresie poziomu i charakteru kapitału społecznego ich członków, wynikające $\mathrm{z}$ wzajemnych relacji między komponentami zaufania, norm i wartości oraz sieci.

Kapitał społeczny członków grup należących do zbioru I (cechujących się nieco korzystniejszymi charakterystykami społeczno-demograficznymi w porównaniu do członków grup zbioru II) osiąga wyższy poziom i jest bardziej spójny. Zależności pomiędzy trzema komponentami kapitału społecznego są istotne statystycznie, zachodzące związki cechują się średnią siłą. Kapitał społeczny respondentów z LGD wchodzących w skład II zbioru ma niższy poziom i jest rozproszony (między poziomem komponentów kapitału społecznego w zasadzie nie odnotowano istotnych zależności).

Nie podważając wartości większej koherencji komponentów kapitału społecznego członków LGD z I zbioru, podkreślić jednak należy, iż największy udział w odnotowanym (wyższym w stosunku do zbioru II) poziomie tego kapitału przedstawicieli wspomnianych grup należy przypisać ich zaufaniu do osób znanych. Przy tym, co ważne, bez pozytywnego przełożenia na zaufanie do pozostałych badanych kategorii osób, czyli instytucji lokalnych oraz osób nieznajomych, spotykanych w różnych sytuacjach życiowych. Potencjalnie wyższą skłonnością (będącą następstwem wyższego poziomu zaufania) do nawiązywania kontaktów z tymi dwiema kategoriami podmiotów życia społecznego wykazali się członkowie LGD ze zbioru II. Tu realizowano również większą liczbę projektów współpracy (przemawiającą za otwartością członków tych struktur na współpracę z innymi, również wcześniej nieznanymi, organizacjami). Niestety, potencjał ten nie przełożył się na konkretne działania w postaci współpracy przedstawicieli różnych sektorów funkcjonujących w ramach grupy na rzecz mieszkańców partnerstwa. Wyższy poziom takiej współpracy, wyrażający się m.in. większą aktywnością w LGD oraz związanym z nią poczuciem większego wpływu na sytuację mieszkańców obszaru objętego wsparciem LGD (zsyntetyzowanych w ramach komponentu sieci), odnotowano wśród członków LGD ze zbioru I. A zatem, wszystkie, przedstawione powyżej konkluzje dotyczące struktury i charakteru 
(raczej wiążącego niż pomostowego) kapitału społecznego lokalnych grup działania odnoszą się w większym stopniu do grup ze zbioru I, niż do grup ze zbioru II.

Mając na uwadze ustalenia zawarte w literaturze przedmiotu, próbowano określić zależność pomiędzy poziomem aktywności gospodarczej na obszarze badanych partnerstw a poziomem kapitału społecznego, jakim dysponują lokalne grupy działania. Uzasadniono powody odejścia od (stosowanego we wcześniejszych rozdziałach) podziału na grupy funkcjonujące na obszarze województw o najmniejszej i największej ich sieci (zbiór I i II) oraz przyjęcie kryteriów, w oparciu o które podzielono cały zbiór partnerstw (18) na trzy kategorie: 1) partnerstwa funkcjonujące na obszarze o ponadprzeciętnym poziomie rozwoju gospodarczego (większość założonych wskaźników tego rozwoju osiągnęła wartość ponadprzeciętną); 2) partnerstwa funkcjonujące na obszarze o przeciętnym poziomie rozwoju gospodarczego; 3) partnerstwa funkcjonujące na obszarze o niższym od przeciętnego poziomie rozwoju gospodarczego.

Okazało się, że najwyższym poziomem kapitału społecznego charakteryzowały się LGD funkcjonujące na obszarach o przeciętnym poziomie rozwoju gospodarczego, co pod znakiem zapytania stawia (lansowaną m.in. przez R. Putnama) tezę o zależności kapitału społecznego i ekonomicznego. Być może zbyt wysoki poziom rozwoju nie pobudza motywacji do podejmowania działań służących zmianom, zaś zbyt niski jego poziom nie stwarza wystarczających warunków do realizacji takich działań.

Zaskakująca okazała się również zależność pomiędzy poziomem aktywności społecznej na terenach objętych działaniami badanych LGD (mierzonej liczbą organizacji społecznych) a poziomem ich kapitału społecznego. Badaną zbiorowość partnerstw również podzielono na trzy kategorie: 1) partnerstwa funkcjonujące na obszarach charakteryzujących się ponadprzeciętnym poziomem aktywności społecznej, 2) partnerstwa funkcjonujące na obszarach charakteryzujących się przeciętnym poziomem aktywności społecznej, 3) partnerstwa funkcjonujące na obszarach charakteryzujących się poziomem aktywności społecznej niższym od przeciętnego. Wykazano mianowicie, że jest ona negatywna - najniższą średnią wartość wskaźnika kapitału społecznego odnotowano wśród grup funkcjonujących na obszarach, na których zarejestrowano stosunkowo największą liczbę organizacji społecznych (stowarzyszeń, fundacji, ochotniczych straży pożarnych i kół gospodyń wiejskich). Z kolei wartości najwyższe, zarówno wskaźnika kapitału społecznego, jak i wszystkich jego komponentów składowych, zaobserwowano w grupach aktywnych na terenach cechujących się stosunkowo najmniejszą liczbą działających organizacji społecznych.

Wysoki poziom kapitału społecznego członków grup zlokalizowanych na obszarach o stosunkowo niskim poziomie aktywności społecznej wynikał przede wszystkim z ich rzeczywistego zaangażowania w działania na rzecz partnerstwa. Być może uzyskany rezultat wiąże się z koniecznością włożenia większego wysiłku w pracę na rzecz obszaru, którego mieszkańcy nie są szczególnie skłon- 
ni do podejmowania jakichkolwiek działań, do wykonania której konieczne są szczególne predyspozycje. Być może osoby angażujące się w prace organizacji działających na terenach charakteryzujących się mniej sprzyjającą atmosferą do podejmowania aktywności społecznej już na starcie charakteryzują się ponadprzeciętnym poziomem kapitału społecznego, wyrażającym się ich stosunkowo wysokim zaufaniem społecznym oraz przekonaniem o konieczności i sensowności podejmowania działań na jej rzecz, za którym takie właśnie działania idą. Przypuszczenie o mniej sprzyjających warunkach funkcjonowania tych LGD zdaje się potwierdzać niska wartość wskaźnika zaufania do władz lokalnych. Być może niechęć do nich pobudza do działania kompensującego słabą aktywność instytucji władzy, a może członkowie LGD z najwyższym kapitałem społecznym (także ludzkim) widzą siebie na stanowiskach w organach władzy i stąd krytyka i nieufność wobec tych instytucji.

Uzyskane dane, choć nie uprawniają do odrzucenia hipotezy mówiącej, iż im wyższy jest poziom aktywności społecznej na danym obszarze, tym wyższy jest także poziom kapitału społecznego członków organizacji działających na jego rzecz, dają jednak solidną podstawę do podania jej w wątpliwość i postawienia hipotezy zakładającej istnienie między badanymi zmiennymi zależności o przeciwnym kierunku.

Nie zaobserwowano różnic między poziomem współpracy reprezentantów sektora publicznego, społecznego i gospodarczego na terenach objętych funkcjonowaniem LGD a poziomem kapitału społecznego ich członków. W tym przypadku charakter pozyskanych danych nie umożliwia jednak jednoznacznego stwierdzenia, czy i w jaki sposób ta współpraca trójsektorowa wpływa na poziom kapitału społecznego, jakim dysponują LGD. Nie sposób dotrzeć do dokumentów, źródeł obiektywnie rejestrujących jej poziom we wszystkich gminach objętych działaniami badanych LGD. Zdobyte informacje mogą być tylko przypuszczeniami informatorów (mimo prośby o sprawdzenie faktów), a w oparciu o nie nie było możliwe wyróżnienie grup funkcjonujących na obszarach istotnie zróżnicowanych pod względem wzajemnych relacji przedstawicieli trzech sektorów. W związku z powyższym niemożliwe okazało się oszacowanie wpływu zróżnicowanego poziomu tej zmiennej na poziom kapitału społecznego badanych LGD.

Przeprowadzone badania wskazały na występowanie dekompozycji cech kapitału społecznego, świadczącej m.in. o słabym związku między deklaracjami respondentów dotyczącymi motywów i wartości kierujących ich postępowaniem a faktycznie realizowanymi przez nich działaniami. Poziom kapitału społecznego LGD nie wzrastał wraz z poziomem aktywności gospodarczej na obszarze partnerstw ani wraz z poziomem aktywności społecznej jego mieszkańców (mierzonej liczbą tworzonych przez nich organizacji pozarządowych). Wbrew ustaleniom literatury przedmiotu okazało się, iż wyższym poziomem kapitału społecznego dysponują LGD na obszarach terenów Zachodnich i Północnych, niższym byłego zaboru austriackiego. 
Lokalne grupy działania nie okazały się strukturami, które reprezentują pomostowe formy kapitału społecznego. Mimo że te ze zbioru pierwszego (Opolszczyzny, Lubuskiego oraz Zachodniopomorskiego) dysponowały wyższym jego poziomem, to jego cechy wskazują, iż ich współpraca odbywa się często w ramach wąskiego i stosunkowo zamkniętego kręgu osób sprawujących (długookresowo) najwyższe funkcje w organach decyzyjnych grupy. Oznacza to ich relatywnie niską skłonność do zawierania nowych kontaktów i tworzenia nowych sieci (zaufaniem obdarzani byli tylko najbliżsi współpracownicy, przede wszystkim z własnego sektora). Chociaż forma prawna LGD (fundacje, stowarzyszenia, związki stowarzyszeń) mogła stanowić przesłankę do traktowania ich jako podmiotów, których funkcjonowanie może (w sposób szczególny) wspierać budowę społeczeństwa obywatelskiego, jest im bliżej do nowych form agencji rozwoju regionalnego, niż do organizacji, które starają się włączać w swoje działania jak największą liczbę członków.

Badane lokalne grupy działania okazały się organizacjami w wysokim stopniu sprofesjonalizowanymi, poddanymi procesowi ekonomizacji, a przede wszystkim zhierarchizowanymi. Aktywna jest w nich relatywnie niewielka część członków (partnerów), tych, którzy realizują w nich różnego rodzaju funkcje. Sposób organizacji ich struktur (w różnym zakresie) może wręcz wykluczać (czy zmniejszać szanse na) partycypację w procesach decyzyjnych samych jej członków (stawiając pod znakiem zapytania realizację niektórych zasad podejścia LEADER - zasady partnerstwa oraz oddolnego podejścia). Warto dodać, iż poczucie wpływu na zmiany mające miejsce na obszarze partnerstwa zdecydowanie częściej wykazywali ci badani, którzy mieli szansę aktywnie uczestniczyć w pracach LGD. W lokalnych grupach działania mamy więc wprawdzie do czynienia ze stosunkowo wysokim poziomem kapitału społecznego, ale jego nośnikami są tylko niektórzy członkowie grup. Jest on warunkowany ich charakterystykami społeczno-demograficznymi (poziomem ich kapitału ludzkiego), a ściślej - cechami tych z nich, którzy wykazują jakiekolwiek zaangażowanie w ich funkcjonowanie (chociażby uczestnicząc $\mathrm{w}$ różnego rodzaju zebraniach).

Niewątpliwie problemem badanych lokalnych grup działania jest niewielkie zaangażowanie $\mathrm{w}$ realizację podejścia LEADER reprezentantów sektora gospodarczego. Wydaje się, że mimo upływu lat niewiele udało się zmienić w tym zakresie. Nadal (na tle reprezentantów sektora społecznego i publicznego) darzeni są oni niższym poziomem zaufania, co nie sprzyja chociażby powierzaniu im realizacji funkcji członków zarządu czy rad tych organizacji.

Zaskakujący okazał się również niski poziom świadomości członków badanych LGD na temat istoty znaczenia rozwoju wielofunkcyjnego i zrównoważonego. Tylko co trzeci (35\%) członek rady zadeklarował, że spotkał się z terminem rozwój wielofunkcyjny, a 48\% - iż znany jest mu termin rozwój zrównoważony. Te osoby już w tym okresie programowania były odpowiedzialne za ocenę wniosków składanych do LGD, których realizacja miała przyczynić się do przekształ- 
cania oblicza polskiej wsi. Zdaje się, iż trudno wykonać ją rzetelnie, w niewielkim stopniu rozumiejąc politykę ich przemian.

Proces tworzenia w Polsce lokalnych grup działania nie wskazywał na to, iż podejście LEADER w krótkim okresie przyczyni się do wzmocnienia tzw. oddolnej inicjatywy mieszkańców wsi. Jego stymulatorem były raczej możliwe do pozyskania środki finansowe niż przekonanie różnych aktorów społecznych (głównie władz lokalnych) co do potrzeby budowania kapitału społecznego mieszkańców wsi.

Dziś celem funkcjonowania tych organizacji jest szeroko rozumiany rozwój wsi, na obecnym etapie jej przekształceń utożsamiany głównie z niwelowaniem różnego rodzaju deficytów jej infrastrukturalnego wyposażenia oraz z generowaniem pozarolniczych form aktywności gospodarczej (stąd ogromne zainteresowanie LGD produktami lokalnymi, stanowiącymi zasoby, których wykorzystanie może przyczyniać się do tworzenia nowych miejsc pracy, np. przy ich przetwórstwie oraz sprzedaży). Wzrost kapitału społecznego mieszkańców wsi stanowi jedynie wartość dodaną (a nie cel główny) pracy członków i partnerów tych organizacji. Jednak (opisana w niniejszej pracy) specyfika ich funkcjonowania nie sprzyja ich efektywności w tym zakresie.

Struktury te często są zbyt duże, by umożliwiać swoim członkom jakiekolwiek aktywne działanie (kształtując w sobie poczucie realnego wpływu na zmianę oblicza wsi, które zamieszkują). Brakuje organów (komórek), które dawałyby możliwość włączenia w prace tych organizacji większej liczby członków. Istniejące, zwłaszcza zarząd i rada, uległy petryfikacji. Określone funkcje sprawują w nich (bardzo często od kilku lat) te same osoby.

W tym kontekście dyskusyjna jest kwestia zachęcania tzw. małych partnerstw (zwłaszcza działających na obszarze zamieszkiwanym przez mniej niż 50 tys. osób) do łączenia się. Argumentem za tak rozumianymi fuzjami są większe środki finansowe, które mogą otrzymywać większe grupy. Przyjmuje się tu założenie, że miarą efektywności ich działania jest liczba zrealizowanych projektów. Większy obszar partnerstwa może jednak ograniczać chociażby możliwość kontaktu mieszkańców wsi z pracownikami biura LGD. Polska wieś nadal mierzy się bowiem z problemem deficytów infrastrukturalnych, dostęp do Internetu jest często ograniczony, zresztą nie wszystkie problemy można rozwiązać za pomocą kontaktu pośredniego.

Dziś obserwujemy, iż aktywność LGD jest ukierunkowana na wybrane grupy odbiorców - mieszkańców wsi. Nie wszyscy z nich (a raczej ich mniejszość) są zrzeszeni w różnych organizacjach, które mogą starać się o środki z działania „Małe projekty”, nie wszyscy są zainteresowani otworzeniem własnej działalności gospodarczej czy zmianą profilu prowadzonej działalności rolniczej. Nie wszyscy mają więc jakiś cel w tym, by w ogóle dowiedzieć się, czy ich wieś jest objęta wsparciem jakiejś lokalnej grupy działania. Rolą tych organizacji jest poinformowanie różnych grup mieszkańców wsi o możliwości włączenia się do 
procesu jej przekształceń. Prowadzenie prac tylko zza biurka (zwłaszcza w społecznościach wiejskich) zdecydowanie nie jest tu wskazane.

Kolejnym problemem LGD jest wysoki poziom ich hierarchizacji i utrudnienia biurokratyczne (często wywołujące strach zarządu i pracowników biura o rozliczenie wydatkowanych środków). Grupy chętniej korzystają z doradztwa tzw. ekspertów i firm wyspecjalizowanych w organizacji różnych przedsięwzięć niż z pomocy mieszkańców wsi. Dodatkowo, mimo że ich członkowie (zresztą przeważnie tylko z rady i zarządu) podnoszą swoje kwalifikacje, to ich wiedza w zakresie mechanizmów rozwoju zawartych we Wspólnej Polityce Rolnej wydaje się niewystarczająca.

A zatem technicyzacja podejścia LEADER w Polsce, tj. ujmowanie go poprzez pryzmat liczby zrealizowanych projektów, członków i partnerów LGD sprawia, że zapomina się o jego istocie, tj. wizji rozwoju wsi, kształtowanej przez jak najszersze grono jej mieszkańców. 


\section{BIBLIOGRAFIA}

Bartkowski J., 2007, Kapitał społeczny i jego oddziaływanie na rozwój w ujęciu socjologicznym, [w:] Kapitat ludzki i kapitał społeczny a rozwój regionalny, red. M. Herbst, Wydawnictwo Naukowe SCHOLAR, Warszawa.

Berelson B., 1952, Content Analysis in Communication research, The Free Press, Glencoe.

Borek T., Fałkowski J., Giejbowicz E., Janiak K., Poślednik A., Zielińska M., 2006, Inicjatywa LEADER - pierwsze doświadczenia i szanse rozwoju, Fundacja Programów Pomocy dla Rolnictwa FAPA, Warszawa.

Borek T., 2007, Realizacja Pilotażowego Programu LEADER+ w Polsce, FAPA, Warszawa.

Bożek J., 2010, Zmiany przestrzennego zróżnicowania struktury agrarnej, zasiewów i użytków rolnych w Polsce w latach 2002 i 2007, „Roczniki Nauk Rolniczych” 97, z. 4.

Bukraba-Rylska I., 2011, Kapitat społeczny polskiej wsi w świetle badań nad programem LEADER, [w:] Między interwencja a interakcja. Lokalne grupy działania w społecznościach wiejskich, red. I. Bukraba-Rylska, Wydawnictwo Naukowe SCHOLAR, Warszawa.

Cybulska A., 2012, Zaufanie spoteczne, CBOS, nr BS/33/2012.

Czapiński J. 2011, Kapitał społeczny, [w:] Diagnoza społeczna 2011. Warunki i jakość życia Polaków, red. J. Czapiński, T. Panek, Rada Monitoringu Społecznego, Warszawa.

Działek J., 2008, Geografia kapitału społecznego. Regionalne zróżnicowanie zasobów kapitatu społecznego w Polsce, [w:] Kapitaty ludzkie i społeczne a konkurencyjność regionów, red. M. Szczepański, K. Bierwiaczonek, T. Nawrocki, Wydawnictwo Uniwersytetu Śląskiego, Katowice.

Dziemianowicz W., Łukomska J., Górska A., Pawluczuk M., 2009, Trendy rozwojowe regionów, Geoprofit, Warszawa.

Fedyszak-Radziejowska B. 2012, Społeczności wiejskie: ewolucyjne zmiany, zrównoważony rozwój, [w:] Polska wieś 2012. Raport o stanie wsi, red. J. Wilkin, I. Nurzyńska, Wydawnictwo Naukowe SCHOLAR.

Frykowski M., 2009, Klasyczne typy kapitału społecznego wśród mieszkańców terenów wiejskich województwa tódzkiego, [w:] Kapitat społeczny. Partycypacja obywatelska. Rozwój lokalny, red. E. Psyk-Piotrowska, Wydawnictwo Uniwersytetu Łódzkiego, Łódź.

Frykowski M., Starosta P., 2008, Kapitat społeczny i jego użytkownicy, „Przegląd Socjologiczny”, LVII/1.

Furmankiewicz M., 2006, Wspótpraca międzysektorowa $w$ ramach partnerstw terytorialnych na obszarach wiejskich w Polsce, „Studia Regionalne i Lokalne” 2(21), Warszawa.

Furmankiewicz M., Janc K., 2011, Wpływ Programu Pilotażowego LEADER+ na aktywność mieszkańców gmin należacych do partnerstw terytorialnych w województwie dolnośląskim, „Wieś i Rolnictwo" 1(150), Warszawa.

Furmankiewicz M., Królikowska K., 2010, Partnerstwa terytorialne na obszarach wiejskich w Polsce w latach 1994-2006, Wydawnictwo Uniwersytetu Przyrodniczego we Wrocławiu, Wrocław. 
Futymski A, Kamiński R., 2008, Budowanie lokalnej strategii rozwoju w ramach osi 4 LEADER Programu Rozwoju Obszarów Wiejskich na lata 2007-2013, Ministerstwo Rolnictwa i Rozwoju Wsi, Warszawa.

Goszczyński W., 2009, Program LEADER jako mechanizm ksztaltowania kapitału społecznego na obszarach wiejskich, [w:] Tworzenie partnerstw lokalnych $i$ ich sieci na obszarach wiejskich. Doświadczenia z funkcjonowania programu LEADER w Polsce w latach 2004-2009, red. K. Wasielewski, Wydawnictwo Uczelniane Wyższej Szkoły Gospodarki w Bydgoszczy, Bydgoszcz.

Grochowska R., Płonka B., 2002, Program Leader instrumentem aktywizacji społeczności lokalnych- wnioski dla Polski, „Wieś i Rolnictwo”, nr 4, IRWiR PAN, Warszawa.

Growiec K., 2011, Kapital społeczny. Geneza i społeczne konsekwencje, Wydawnictwo Szkoły Wyższej Psychologii Społecznej „Academica”, Warszawa.

Halamska M., 2009, Zasoby własne wsi a zewnętrzne programy rozwoju. Na przykładzie zależności kapitat społeczny - PP LEADER+, „Wieś i Rolnictwo” 3(144), IRWiR PAN, Warszawa.

Halamska M., 2011, Sceny rozwoju lokalnego w Polsce: dekoracje i aktorzy, „Wieś i Rolnictwo” 4(153), Warszawa.

Halamska M., Michalska S., Śpiewak R., 2010, LEADER w Polsce. Drogi implementacji programu, „Wieś i Rolnictwo” 4(149), Warszawa.

Hanke K., 2006, Perspektywa tworzenia lokalnych grup działania w programie LEADER, „Wieś i Rolnictwo" 3(132), Warszawa.

Hanke K., 2009, Lokalna Grupa Działania - sieć czy podsieci? Problemy funkcjonowania LGD z perspektywy teorii wymiany, [w:] Tworzenie partnerstw lokalnych i ich sieci na obszarach wiejskich. Doświadczenia z funkcjonowania programu LEADER w Polsce w latach 20042009, red. K. Wasielewski, Wydawnictwo Uczelniane Wyższej Szkoły Gospodarki w Bydgoszczy, Bydgoszcz.

Hanke K., Psyk-Piotrowska E., 2006, Analiza SWOT wdrażania pilotażowego programu LEADER+ na podstawie badań w dwóch gminach, „Wieś i Rolnictwo” 4(133), Warszawa.

Hanke K., Psyk-Piotrowska E., 2009, Partnerstwo jako metoda włączania społeczności lokalnych w rozwój obszarów wiejskich, [w:] Kapitat społeczny, partycypacja obywatelska, rozwój lokal$n y$, red. E. Psyk-Piotrowska, Wydawnictwo Uniwersytetu Łódzkiego, Łódź.

Heller J., 2008, Poziom rozwoju gospodarczego województw a dochody samorządów terytorialnych $w$ Polsce, „Studia Regionalne i Lokalne” 4(34), Warszawa.

Herbst J., 2008, Kraina nieufności: kapitat społeczny, rozwój gospodarczy i sprawność instytucji publicznych w polskiej literaturze akademickiej, [w:] Szafarze darów europejskich. Kapitat społeczny a realizacja polityki regionalnej w polskich województwach, red. P. Swianiewicz, J. Herbst, M. Lackowska, A. Mielczarek, Wydawnictwo Naukowe SCHOLAR, Warszawa.

Herbst M., 2007, Wpływ kapitalu ludzkiego i społecznego na (krótkookresowy) wzrost gospodarczy w polskich podregionach, [w:] Kapitał ludzki i kapitał społeczny a rozwój regionalny, M. Herbst (red.), Wydawnictwo Naukowe SCHOLAR, Warszawa.

Hryniewicz J., 2006, Dziedzictwo rozbioru pruskiego w gospodarce i polityce, [w:] Kapitaty: ludzie i instytucje. Studia i szkice socjologiczne, red. M. Szczepański, A. Śliz, Wyższa Szkoła Zarządzania i Nauk Społecznych w Tychach, Uniwersytet Opolski, Tychy-Opole.

Kamiński R., 2011, Oddolnie czy odgórnie - jak program LEADER wplywa na społeczności wiejskie?, [w:] Między interwencją a interakcja. Lokalne grupy działania w społecznościach wiejskich, red. I. Bukraba-Rylska, Wydawnictwo Naukowe SCHOLAR, Warszawa.

Kamiński R., Kwatera K., 2005, Jak budować Zintegrowana Strategię Rozwoju Obszarów Wiejskich w ramach Pilotażowego Programu LEADER+, Fundacja Fundusz Współpracy, Agrolinia, Warszawa.

Klepacka D.,2003, Inicjatywa wspólnotowa Leader - doświadczenia funkcjonowania w wybranych krajach UE, „Wieś i Rolnictwo”, nr 4, IRWiR PAN, Warszawa. 
Knieć W., 2007, Władza w LGD, „Kwartalnik LEADER+”, nr 4, FAPA, FAOW, CDR, KRiR, Warszawa.

Knieć W., 2010, Partnerstwa lokalne w Polsce - kondycja, struktura, wyzwania. Raport badawczy, Fundacja Partnerstwo dla Środowiska, Kraków-Torun.

Knieć W., Hałasiewicz A., 2008, LEADER. Budowanie potencjału społecznego, Fundacja Pomocy dla Rolnictwa FAPA, Warszawa.

LEADER - czy można lepiej, Raport z debaty oraz komentarze i uwagi, Fundacja Wspomagania Wsi, Warszawa 2011.

Merton R., 1996, On Social Structure and Science, University of Chicago Press, Chicago.

Michalska S., Zajda K., 2011, Trajektorie wykorzystania zasobów lokalnych w procesie rozwoju partnerstw terytorialnych. Case study lokalnych grup dziatania „,Dolina Karpia” oraz „,Kraina Rawki”, „Wieś i Rolnictwo” 4 (153), Warszawa.

Niesporek A., 2008, Miejsce i funkcja pojęcia kapitalu społecznego w teorii socjologicznej, [w:] Kapitały ludzkie i społeczne a konkurencyjność regionów, red. M. Szczepański, K. Bierwiaczonek, T. Nawrocki, Wydawnictwo Uniwersytetu Śląskiego, Katowice.

Olech A., 2012, Diagnoza stanu partycypacji publicznej, [w:] Dyktat czy uczestnictwo? Diagnoza partycypacji publicznej w Polsce, red. A. Olech, Instytut Spraw Publicznych, Warszawa.

Oś 4 PROW 2007-2013 - Lokalne Grupy Działania i Lokalne Strategie Rozwoju, Ministerstwo Rolnictwa i Rozwoju Wsi, Warszawa 2009.

Peisert A., Kontarowski T., 2012, Tradycje obywatelskie polskich regionów a partycypacja obywatelska, [w:] Dyktat czy uczestnictwo? Diagnoza partycypacji publicznej w Polsce, red. A. Olech, Instytut Spraw Publicznych, Warszawa.

Podsumowanie spotkania roboczego poświęconego przyszłości podejścia Leader oraz problemów zidentyfikowanych na etapie wdrażania osi IV PROW 2007-2013 dostępne na stronie http:// www.leaderafter2013.eu/ - [05.12.2012].

Podsumowanie spotkania roboczego poświęconego przyszłości podejścia Leader oraz problemów zidentyfikowanych na etapie wdrażania osi IV PROW 2007-2013, dostępne na stronie http://www.lgd.malopolska.pl/pliki/podsumowanie\%20spotkania\%2012-13\%20maj.pdf [05.12.2012].

Putnam R., 1995, Demokracja w działaniu. Tradycje obywatelskie we wspótczesnych Włoszech, Społeczny Instytut Wydawniczy ZNAK, Fundacja im. Stefana Batorego, Kraków-Warszawa.

Putnam R., 2008, Samotna gra w kręgle. Upadek i odrodzenie wspólnot lokalnych w Stanach Zjednoczonych, Wydawnictwa Akademickie i Profesjonalne, Warszawa.

Raport PSDB 2012: Ocena funkcjonowania LGD realizujacych LSR w ramach PROW 2007-2013, maszynopis niepublikowany, Warszawa.

Rosner A., 2002, Zróżnicowanie przestrzenne obszarów wiejskich pod kątem widzenia struktur gospodarczych, [w:] Wiejskie obszary kumulacji barier rozwojowych, red. A. Rosner, IRWiR PAN, Warszawa.

Rymsza A., 2007, Klasyczne koncepcje kapitatu społecznego, [w:] Kapitat społeczny. Ekonomia społeczna, red. T. Kaźmierczak, M. Rymsza, Instytut Spraw Publicznych, Warszawa.

Sobiesiak-Penszko P., Kotnarowski M., 2012, Dyktat czy uczestnictwo? Diagnoza partycypacji publicznej w Polsce, red. A. Olech, Instytut Spraw Publicznych, Warszawa.

Stake R., Studium przypadku, [w:] Ewaluacja w edukacji, red. L. Korporowicz, Oficyna Naukowa, Warszawa 1996.

Starosta P., 1995, Poza metropolia. Wiejskie i małomiasteczkowe zbiorowości lokalne a wzory porządku makrospolecznego, Wydawnictwo Uniwersytetu Łódzkiego, Łódź.

Starosta P., Frykowski M., 2008, Typy kapitału społecznego i wzory partycypacji obywatelskiej $w$ wiejskich gminach centralnej Polski, [w:] Kapitaty ludzkie i społeczne a konkurencyjność regionów, red. M. Szczepański, K. Bierwiaczonek, T. Nawrocki, Wydawnictwo Uniwersytetu Śląskiego, Katowice. 
Starosta P., Frykowski M., 2012, Kapitat społeczny. Podstawy teoretyczne, [w:] Zróżnicowanie zasobów kapitału ludzkiego i społecznego w regionie łódzkim, red. P. Starosta, Wydawnictwo Uniwersytetu Łódzkiego, Łódź.

Sułek A., 2011, Doświadczenie, działania dla społeczności i kompetencje obywatelskie, [w:] Diagnoza społeczna 2011. Warunki i jakość życia Polaków, red. J. Czapiński, T. Panek, Rada Monitoringu Społecznego, Warszawa.

Sutton W., Kolaja J., 1960, Elements of Community Action, "Social Forces”, No. 38.

Śpiewak R., 2009, Społeczności realizujące program LEADER+: wyrównywanie czy pogłębianie zróżnicowań?, [w:] Regionalny wymiar procesów transformacyjnych, zróżnicowania i podziaty, red. A. Tuziak, B. Tuziak, Wydawnictwo Naukowe SCHOLAR, Warszawa.

Theiss M., Żukowski T., 2008, Stowarzyszeniowo-obywatelski kapitat społeczny. Komunikat z badań CBOS, wrzesień, Warszawa.

Wieruszewska M., 2011, Zarzadzanie programem LEADER z perspektywy kapitatu społecznego. Założenia, działania, efekty - próba ewaluacji jakościowej, [w:] Między interwencją a interakcja. Lokalne grupy działania w społecznościach wiejskich, red. I. Bukraba-Rylska, Wydawnictwo Naukowe SCHOLAR, Warszawa.

Yin R., 1989, Case Study Research. Design and Methods, New Delhi Sage Publication, Newbury Park, London.

Zajda K., 2011a, Nowe formy kapitalu społecznego wsi, Wydawnictwo Uniwersytetu Lódzkiego, Łódź.

Zajda K., 2011b, Relacje między członkami lokalnych grup działania a podstawowe podejścia w metodzie LEADER. Studium przypadku partnerstw z województwa tódzkiego, „Wieś i Rolnictwo” 2(151).

Zajda K., 2012, Przyczyny niestosowania podejścia LEADER w gminach wiejskich województwa łódzkiego, „Wieś i Rolnictwo” 2(155).

Zajda K., 2013, Innowacja w wiejskiej przedsiębiorczości. Studium przypadku działalności gospodarczej z obszaru Doliny Pilicy, „Studia Regionalne i Lokalne” 1(51).

Zajda K., Dzikowska E., 2012, Innovative use of resources and diversification of the economic structure of rural areas on the basis of local action group MROGA experience, "Journal of Agribusiness and Rural Development" 3(25).

Żolik M. 2010, Wdrażanie schematu II Pilotażowego Programu LEADER+w Wielkopolsce, "Journal of Agribusiness and Rural Development" 3(17). 


\section{ANEKS}

\section{Spis tabel}

Tabela 1. Wykaz podpisanych umów w schemacie II ..................................................... 36

Tabela 2. Cechy LGD z województwa lubuskiego .................................................................... 38

Tabela 3. Cechy LGD z województwa opolskiego............................................................ 39

Tabela 4. Cechy LGD z województwa zachodniopomorskiego .......................................... 40

Tabela 5. Cechy LGD z województwa wielkopolskiego.................................................. 41

Tabela 6. Cechy LGD z województwa małopolskiego ........................................................ 41

Tabela 7. Cechy LGD z województwa podkarpackiego ....................................................... 44

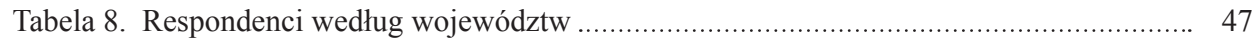

Tabela 9. Liczebność respondentów z poszczególnych sektorów........................................ 48

Tabela 10. Staż członkostwa w LGD według sektorów............................................................ 48

Tabela 11. Funkcje respondentów w LGD......................................................................... 49

Tabela 12. Staż członkostwa w LGD a pełniona funkcja ................................................. 50

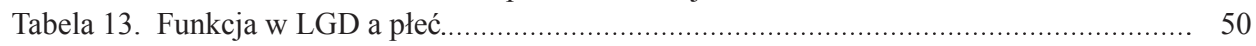

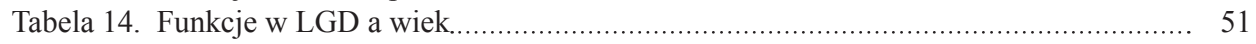

Tabela 15. Respondenci według wieku......................................................................... 52

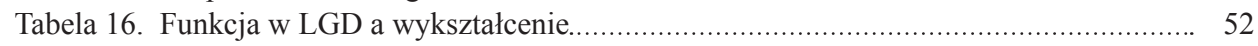

Tabela 17. Respondenci według kategorii społeczno-zawodowych ..................................... 53

Tabela 18. Poziom zainteresowania polityką................................................................... 55

Tabela 19. Udział w ostatnich wyborach prezydenckich .................................................. 56

Tabela 20. Udział w wyborach samorządowych .............................................................. 56

Tabela 21. Udział w wyborach parlamentarnych................................................................... 57

Tabela 22. Deklaracja potrzeby zmian sposobu funkcjonowania władzy lokalnej.................... 61

Tabela 23. Podmiot odpowiedzialny za rozwiązywanie problemów wsi/gminy ........................ 61

Tabela 24. Ocena własnego wpływu na sytuację w miejscowości/gminie według wykształcenia... 63

Tabela 25. Ocena wpływu respondenta na decyzje władz lokalnych..................................... 64

Tabela 26. Zaufanie członków LGD do współpracowników z tej organizacji.......................... 70

Tabela 27. Rozkłady odpowiedzi na pytania wskaźnikowe - poziom zaufania do osób znanych... 71

Tabela 28. Składowe komponentu zaufania - zaufanie do osób znanych................................ 72

Tabela 29. Rozkłady odpowiedzi na pytania wskaźnikowe - poziom zaufania społecznego..... 73

Tabela 30. Składowe komponentu zaufania - zaufanie społeczne …...................................... 74

Tabela 31. Rozkłady odpowiedzi na pytania wskaźnikowe - poziom zaufania do instytucji

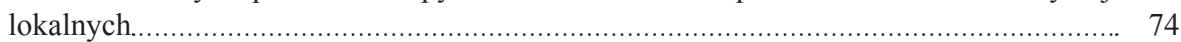

Tabela 32. Składowe komponentu zaufania - zaufanie do instytucji i organizacji lokalnych.... 76

Tabela 33. Rozkłady odpowiedzi na pytania wskaźnikowe - patriotyzm lokalny .................... 78

Tabela 34. Składowe komponentu norm i wartości - patriotyzm lokalny .................................. 78

Tabela 35. Opinie badanych na temat interesów reprezentowanych przez większość człon- 
Tabela 36. Rozkłady odpowiedzi na pytania wskaźnikowe - normy i wartości LGD ............... 80

Tabela 37. Składowe komponentu norm i wartości - normy/wartości związane z LGD............ 81

Tabela 38. Rozkłady odpowiedzi na pytania wskaźnikowe - społecznikostwo i podmiotowość... 82

Tabela 39. Składowe komponentu norm i wartości - społecznikostwo i poczucie podmiotowości.

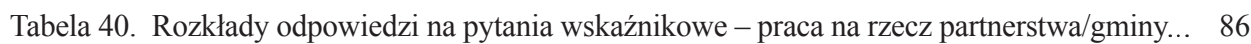

Tabela 41. Składowe komponentu sieci - współpraca na rzecz partnerstwa lub gminy .............. 86

Tabela 42. Rozkłady odpowiedzi na pytania wskaźnikowe - udział w działaniach LGD......... 87

Tabela 43. Składowe komponentu sieci - uczestnictwo w pracach LGD............................... 89

Tabela 44. Opinie badanych na temat efektów wdrażania podejścia LEADER ....................... 91

Tabela 45. Rozkłady odpowiedzi na pytania wskaźnikowe - wpływ na funkcjonowanie partnerstwa.

Tabela 46. Składowe komponentu sieci - poczucie wpływu na funkcjonowanie LGD ............. 94

Tabela 47. Związek między komponentami kapitału społecznego ....................................... 96

Tabela 48. Charakterystyki społeczno-demograficzne władz LGD (w \%) .............................. 104

Tabela 49. Wartość elementów składowych komponentu zaufania w LGD z porównywanych zbiorów.

Tabela 50. Wartość elementów składowych komponentu normi wartości w LGD z porównywanych zbiorów.

Tabela 51. Wartości elementów składowych komponentu sieci w LGD z porównywanych zbiorów.

Tabela 52. Związek między komponentami kapitału społecznego w LGD ze zbioru I .............. 111

Tabela 53. Analizowane wymiary sfery gospodarczej..................................................... 117

Tabela 54. Poziom komponentów kapitału społecznego w LGD funkcjonujących na obszarach o różnym poziomie rozwoju gospodarczego.

Tabela 55. Rodzaje organizacji funkcjonujących na obszarze badanych partnerstw według deklaracji członków LGD.

Tabela 56. Wskaźniki aktywności społecznej na obszarze wybranych partnerstw..

Tabela 57. Poziom komponentów kapitału społecznego w LGD funkcjonujących na obszarach o różnym poziomie aktywności społecznej.

Tabela 58. Stosunek do władz lokalnych a poziom kapitału społecznego członków LGD.......... 133

Tabela 59. Współpraca trójsektorowa w badanych partnerstwach.

\section{Spis wykresów}

Wykres 1. Poziom komponentu zaufania w badanych LGD. 77

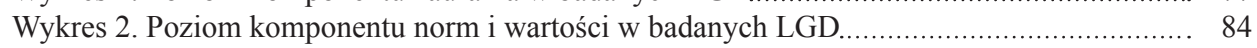

Wykres 3. Poziom komponentu sieci w badanych LGD ……...................................................... 94

Wykres 4. Poziom kapitału społecznego w badanych LGD (suma komponentów)........................ 95

Wykres 5. Poziom komponentów kapitału społecznego badanych LGD ................................ 98

Wykres 6. Wiek członków LGD należących do obu zbiorów............................................ 101

Wykres 7. Kategorie zawodowe członków LGD .................................................................... 102

Wykres 8. Wykształcenie członków porównywanych LGD ................................................ 103

Wykres 9. Skład LGD ze względu na pełnione funkcje ...................................................... 104

Wykres 10. Liczba członków zarządu i rady LGD oraz liczba zrealizowanych projektów......... 105

Wykres 11. Projekty realizowane przez LGD ............................................................... 106

Wykres 12. Poziom kapitału społecznego w grupach z pierwszego i drugiego zbioru ................ 110

Wykres 13. Poziom kapitału społecznego członków LGD funkcjonujących na obszarach o róż-

nym poziomie rozwoju gospodarczego. 


\section{Załączniki}

\section{Załącznik 1. Kwestionariusz ankiety}

Szanowni Państwo,

Katedra Socjologii Wsi i Miasta Uniwersytetu Eódzkiego na podstawie umowy zawartej z Narodowym Centrum Nauki ( $\mathrm{nr}$ 6996/B/H03/2011/40) rozpoczęła realizację projektu badawczego pt. ,,Struktura i uwarunkowania kapitału społecznego lokalnych grup działania”.

Badania będa prowadzone na obszarze 6 województw to jest: lubuskiego, opolskiego, zachodniopomorskiego, matopolskiego, podkarpackiego, wielkopolskiego a ich celem jest rozpoznanie specyfiki lokalnych grup działania oraz ich znaczenia dla rozwoju obszarów wiejskich.

Udziat każdego członka lokalnej grupy działania ma dla nas bardzo duże znaczenie dlatego zwracamy się do Państwa z prośbą o wzięcie udziału w badaniach. Gwarantujemy, iż informacje, których Państwo nam udziela zostana, zgodnie z ustawa o ochronie danych osobowych, objęte tajemnica i postuża jedynie do opracowania zbiorczych zestawień nie zawierajacych danych, które w jakikolwiek sposób pozwolityby na zidentyfikowanie osoby wypetniającej ankietę.

Bardzo prosimy o udzielanie szczerych i wyczerpujacych odpowiedzi na nasze pytania.

Łódź 2011

\section{Specyfika lokalnych grup działania oraz ich znaczenie dla rozwoju wsi}

1. Lokalna grupe działania tworza przedstawiciele różnych instytucji, organizacji lub grup osób, które można przydzielić do 3 sektorów tj. publicznego (np. samorząd gminy, Gminny Ośrodek Kultury), społecznego (np. stowarzyszenia, fundacje, koła gospodyń wiejskich) oraz gospodarczego (np. lokalni przedsiębiorcy, rolnicy). Czy Pan(i) jest w LGD przedstawicielem:
1. sektora publicznego
2. sektora gospodarczego
3. sektora społecznego?

2. Czy w swojej LGD jest Pan(i) członkiem:
1. zarządu LGD
1.tak
2. nie
2. rady LGD
1.tak
2. nie
3. komisji rewizyjnej LGD
1.tak
2. nie

3. Podejście LEADER $w$ Polsce wdrażane było w ramach Pilotażowego Programu LEADER+ (którego realizacja zakończyła się w 2008 r.). Obecnie jest realizowane za pomoca Programu Rozwoju Obszarów Wiejskich. Czy jest Pan(i) członkiem lokalnej grupy działania od czasu wdrażania Pilotażowego Programu LEADER+?

1.tak 2.nie - prosze przejść do pytania $\mathrm{nr} 11$

4. Jak często w czasie realizacji Pilotażowego Programu LEADER+odbywaty się zebrania formalne:

1. członków zarządu lokalnej grupy działania
1. częściej niż raz w miesiącu
2. raz w miesiącu
3. rzadziej niż raz w miesiącu?

2. wszystkich członków lokalnej grupy działania (tzw. walne zebrania członków)?
1. częściej niż raz w miesiącu
2. raz w miesiącu
3. rzadziej niż raz w miesiącu?

5. Jak często w okresie realizacji Pilotażowego Programu LEADER+ uczestniczyt(a) Pan(i) w zebraniach lokalnej grupy działania?

1. zawsze (we wszystkich zebraniach)

4. rzadko (w mniej niż połowie zebrań)

2. często (w większości zebrań)

5. nigdy lub prawie nigdy

3. czasami (w około połowie zebrań) 
6. Jak w czasie realizacji Pilotażowego Programu LEADER+ przedstawiała się Pana(i) aktywność w lokalnej grupie działania na tle większości jejuczestników? Czy byt(a) Pan(i):

1. bardziej aktywny(a) niż większość uczestników grupy

2. tak samo aktywny(a) jak większość uczestników grupy, czy też

3. mniej aktywny(a) niż większość uczestników grupy

7. A na czym polegała Pana(i) aktywnossć w LGD w tym okresie (to jest $w$ czasie realizacji Pilotażowego Programu LEADER+)? Proszę wybrać odpowiedź najlepiej charakteryzująca Pana/Pani aktywność:

1. byłem(am) członkiem grupy tylko formalnie

2. ograniczałem(am) się do zabierania głosu na spotkaniach grupy

3. nie tylko zabierałem(am) głos na spotkaniach grupy, ale także działałem(am) przy realizacji różnych inicjatyw grupy

8. Czy Pana(i) zdaniem wdrażanie Pilotażowego Programu LEADER+ było trudne, skomplikowane?
1. tak
2. nie-prosze przejść do pytania nr 10

9. Czy liczyt(a) Pan(i) na to, iż procedury realizacji podejścia LEADER zostanq uproszczone?
1. tak
2. Nie

10. Jak często obecnie odbywaja się zebrania formalne:

1. członków zarzadu lokalnej grupy działania

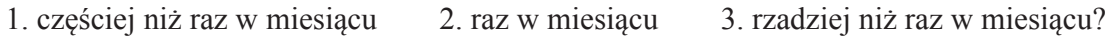

2. wszystkich członków lokalnej grupy działania (tzw. walne zebrania członków)?

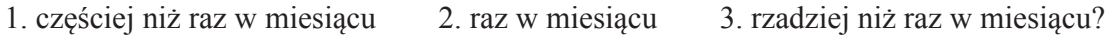

3.członków rady lokalnej grupy działania

$\begin{array}{lll}\text { 1. częściej niż raz w miesiącu } & \text { 2. raz w miesiącu } & \text { 3. rzadziej niż raz w miesiącu? }\end{array}$

11. Jak często obecnie uczestniczy Pan(i) w walnych zebraniach członków lokalnej grupy działania:

1. zawsze (we wszystkich zebraniach)

4. rzadko (w mniej niż połowie zebrań)

2. często (w większości zebrań)

5. nigdy lub prawie nigdy

3. czasami (w około połowie zebrań)

12. Jak ocenit(a)by Pan(i) swoją aktywność w lokalnej grupie działania na tle większości jejuczestników? Czy jest Pan(i)

1. bardziej aktywny(a) niż większość uczestników grupy

2. tak samo aktywny(a) jak większość uczestników grupy

3. mniej aktywny(a) niż większość uczestników grupy?

13. A na czym obecnie polega Pana(i) aktywność w LGD? Proszę wybrać odpowiedź najlepiej charakteryzująca Pana/Pani aktywność:

1. jestem członkiem grupy tylko formalnie

2. ograniczam się do zabierania głosu na spotkaniach grupy

3. nie tylko zabieram głos na spotkaniach grupy, ale także działałam przy realizacji różnych inicjatyw grupy - proszę przejść do pytania $\mathrm{nr} 15$

14. Dlaczego obecnie nie uczestniczy Pan(i) w inicjatywach na rzecz mieszkańców gmin tworzacych obszar partnerstwa? Z podanej listy proszę wskazać nie więcej niż 2 odpowiedzi:

1. nie mam czasu na działalność w takich inicjatywach 
2. nie posiadam dobrych doświadczeń we współpracy z innymi członkami LGD

3. nie byłem(am) poinformowany(a) o tym, że jakaś inicjatywa będzie realizowana

4. uważam, że inni członkowie LGD na pewno sprawdzą się lepiej

5. uważam, że te inicjatywy wcale nie pomagają mieszkańcom gmin tworzących obszar partnerstwa

6. realizacją inicjatyw zawsze zajmują się te same osoby, a ja nie mogę się wykazać, chociaż chciał(a)bym

15. Czy w lokalnej grupie działania sa jakieś osoby szczególnie wyróżniające się swoją aktywnością?

1. tak 2. nie -proszęprzejść do pytania 18

16. Ile jest takich osób?
1. 1
2. $2-3$
3. 4-5
4. więcej niż 5

17. Jakie sa główne motywy działania najbardziej aktywnych osób? Z podanej listy proszę wskazać nie więcej niż 2 odpowiedzi.

Motywem działania najbardziej aktywnych w LGD osób jest chęć:

1. działania na rzecz mieszkańców wszystkich gmin tworzących obszar partnerstwa

2. działania tylko na rzecz mieszkańców swojej gminy

3. działania tylko na rzecz interesów sektora, który ta osoba reprezentuje

4. zdobycia wyróżniającej pozycji w LGD

5. zdobycia doświadczenia zawodowego

6. zarobienia dodatkowych pieniędzy

7. wypromowania swojej osoby wśród członków społeczności lokalnej

8. inne, jakie?.

18. Czasami zdarza się, iż członkowie lokalnej grupy działania nie uczestnicza $w$ zebraniach poświęconych jej funkcjonowaniu. Jakie moga być tego powody? Z podanej listy prosze wybrać nie więcej niż 3 najważniejsze wedtug Pana/Pani powody.

1. spotkania są organizowane $\mathrm{w}$ godzinach ich pracy

2. nie dociera do nich informacja o planowanych spotkaniach

3. po pracy są zajęci innymi obowiązkami

4. uważają, iż ich obecność na spotkaniu nie jest ważna, ponieważ nikt nie liczy się z ich zdaniem

5. uważają, że obecność na spotkaniach to strata czasu, ponieważ i tak żadna ważna decyzja nie będzie podjęta

6. uważają, że lokalna grupa działania nie jest w stanie nic zrobić dla mieszkańców gmin tworzących partnerstwo

7. w LGD znajdują się osoby, których nie lubią i wolą uniknąć kontaktu z nimi

19. Czy procedury prawne i finansowe regulujace funkcjonowanie lokalnej grupy działania powinni znać:

1. wszyscy członkowie lokalnej grupy działania, czy też

2. tylko osoby bezpośrednio zaangażowane w realizację projektów, wydatkowanie tych środków? 
20. Jak Pan(i) obecnie ocenia swoja decyzję o przystapieniu do LGD?

1. zdecydowanie pozytywnie

2. raczej pozytywnie

3. ani pozytywnie ani negatywnie

4. raczej negatywnie

5. zdecydowanie negatywnie

21. Czy Pana(i) zdaniem wdrażanie podejścia LEADER w ramach Programu Rozwoju Obszarów Wiejskich jest trudne, skomplikowane?

1. tak nie-prosze przejść do pytania $n$ r 26

22. Co Pana(i) zdaniem sprawia największa trudność lokalnym grupom działania $w$ realizacji podejścia LEADER?

23. W jaki sposób Pana(i) zdaniem tę trudność można zminimalizować?

24. Czy sadzi Pan(i), iż w przyszłości procedury związane z funkcjonowaniem lokalnych grup dziatania w Polsce będq uproszczone?

1. tak - proszę przejść do pytania nr 26

2. nie

25. Dlaczego Pana(i) zdaniem procedury zwiazane z funkcjonowaniem lokalnych grup działania $w$ Polsce $w$ przyszłości nie zostana uproszczone?

\begin{tabular}{|c|l|c|c|c|}
\hline $\mathbf{2 6}$ & $\begin{array}{l}\text { Czy uważa Pan(i), że dotychczasowe funkcjonowanie lokalnej } \\
\text { grupy działania sprzyjało: }\end{array}$ & tak & nie & $\begin{array}{c}\text { trudno po- } \\
\text { wiedzieć }\end{array}$ \\
\hline 1 & $\begin{array}{l}\text { zaangażowaniu mieszkańców gmin tworzących obszar partner- } \\
\text { stwa w działalność na rzecz ich rozwoju }\end{array}$ & $\begin{array}{l}\text { zmniejszaniu poziomu bezrobocia wśród mieszkańców gmin } \\
\text { tworzących obszar partnerstwa }\end{array}$ & & \\
\hline 3 & rozwojowi kwalifikacji i umiejętności członków LGD & $\begin{array}{l}\text { rze gmin tworzących obszar partnerstwa np. agroturystyka, } \\
\text { produkty lokalne }\end{array}$ & & \\
\hline 5 & promocji gmin tworzących obszar partnerstwa & & \\
\hline 6 & $\begin{array}{l}\text { integracji członków LGD, której efektem jest wspólna praca na } \\
\text { rzecz wszystkich gmin tworzących obszar partnerstwa }\end{array}$ & & \\
\hline
\end{tabular}


27. Czy zamierza Pan(i) kontynuować działalność w lokalnej grupie działania?
1.tak
2.nie

28. Gdyby miat(a) Pan(i) możliwość zamieszkania tam, gdzie zechce, to czy:

1. pozostał(a)by Pan (i) tu, gdzie mieszka obecnie - prosze przejść do pytania 31

2. przeprowadził(a)by się Pan(i)

29. Dlaczego chciat(a)by się Pan(i) przeprowadzić? Z podanej listy proszę wybrać nie więcej niż 3 odpowiedzi.

Chciał(a)bym się przeprowadzić ze względu na:

1. małą liczbę ofert pracy

2. małą ilość ofert spędzania czasu wolnego

3. słabo rozwiniętą infrastrukturę m.in. drogi, wodociągi, gazociągi

4. słabo rozwiniętą sieć usług handlowych

5. słabe perspektywy edukacyjne dla moich dzieci

6. niską ocenę działalności władz lokalnych

7. niechęć mieszkańców do współdziałania

30. Dokąd chciat(a)by Pan(i) się przeprowadzić?

1. do innej wsi

2. do małego miasta (do 100 tys. mieszkańców)

3. do miasta średniej wielkości (101 - 500 tys. mieszkańców)

4. do dużego miasta (powyżej 500 tys. mieszkańców)

5. zagranicę - na wieś

6. zagranicę - do miasta

31. Czy przed przystapieniem do lokalnej grupy działania angażował(a) się Pan(i) w jakakolwiek działalność na rzecz mieszkańców gminy?

1. tak 2. nie-proszę przejść do pytania 33

32. Co Pan(i) wcześniej robił(a) na rzecz mieszkańców gminy? Z podanej listy proszę wybrać wszystkie prawdziwe odpowiedzi.

1. sprawowałem(am) funkcję publiczną np. radny, sołtys, wójt

2. pracowałem(am) w instytucji działającej na rzecz mieszkańców gminy i poprzez to byłem(am) zaangażowany(a) w działalność na ich rzecz (np. w Urzędzie Gminy, w GOPS, w GOK)

3. byłem(am) członkiem organizacji pozarządowej działającej na rzecz mieszkańców gminy

4. sponsorowałem(am) różne inicjatywy na rzecz mieszkańców

5. jako osoba prywatna angażowałem(am) się w różne inicjatywy na rzecz mieszkańców organizowane przez inne osoby/instytucje

6. zgłaszałem(am) potrzebę realizacji jakiegoś przedsięwzięcia na rzecz mieszkańców gminy do lokalnych instytucji

7. byłem(am) inicjatorem(ką) protestów

8. inne, jakie?

33. Czy zdarzyło się Panu(i), zanim przystapit Pan(i) do lokalnej grupy działania, brać udział w wydarzeniach związanych z promowaniem kultury lokalnej ( $t$. promowaniem lokalnych zespołów śpiewaczych, tanecznych, sztuki ludowej czy lokalnych produktów)?
1. tak
2. nie 
34. Czy ofiarował(a)by Pan(i) jakąś sumę pieniędzy na rzecz organizacji wydarzenia promującego kulturę lokalną?
1. tak
2. nie-prosze przejść do pytania $n r 36$

35. Jaka sumę pieniędzy byt(a)by Pan(i) skłonna ofiarować na rzecz organizacji wydarzenia promującego kulturę lokalną:
1. do $10 \mathrm{zl}$
2. od 11 do $20 \mathrm{zt}$
3. od 21 do $30 \mathrm{zl}$
4. od 31 do $40 \mathrm{zl}$
5. od 41 do $50 \mathrm{zł}$
6. powyżej $50 \mathrm{zł}$

36. Proszę wskazać, z którą z poniższych opinii Pan(i) się zgadza:

1. Obecnie trzeba walczyć o swoje sprawy nie zważając na innych ludzi

2. Obecnie należy być wrażliwym i gotowym do pomocy innym ludziom

37. Niektórzy ludzie czują, ze mają kontrolę nad własnym życiem, sa kowalami własnego losu, podczas gdy w odczuciu innych ich los od nich nie zależy. Na poniższej skali ,, 1 " oznacza calkowity brak kontroli, a „10” petna kontrolę nad wtasnym życiem. Proszę na skali wskazać punkt określajacy w jakim stopniu Pana (i) życie zależy od Pana(i) decyzji?

$\begin{array}{llllllllll}1 & 2 & 3 & 4 & 5 & 6 & 7 & 8 & 9 & 10 \\ \begin{array}{l}\text { Całkowity } \\ \text { brak kontroli }\end{array} & & & & & & & & & \text { Pełna kontrola }\end{array}$

38. Czyje interesy Pana(i) zdaniem reprezentuje większość członków LGD? Czy sa to interesy:
1. mieszkańców wszystkich gmin tworzących obszar partnerstwa
2. mieszkańców swojej gminy
3. sektora do którego należą (publicznego, społecznego, gospodarczego)
4. osobiste

39. A czyje interesy reprezentuje Pan(i) uczestniczac w lokalnej grupie dziatania? Czy sa to interesy:

1. mieszkańców wszystkich gmin tworzących obszar partnerstwa

2. mieszkańców swojej gminy

3. sektora do którego Pan(i) należy

4. osobiste

40. Proszę wskazać opinię, która jest bliższa Pana(i) poglądom:

1. wszyscy członkowie LGD powinni ze sobą współpracować na rzecz rozwoju gmin tworzących obszar partnerstwa niezależnie od tego jaki sektor reprezentują (społeczny, publiczny, gospodarczy)

2. działając na rzecz rozwoju gmin tworzących obszar partnerstwa członkowie LGD powinni współpracować głównie z osobami reprezentującymi ten sam sektor (społeczny, publiczny, gospodarczy)

41. Ludzie $w$ różnym stopniu sq $w$ stanie zaufać innym ludziom. Czy, ogólnie rzecz biorąc, uważa Pan(i), ̇̇e:

1. większości ludzi można zaufać

2. większości ludzi nie można zaufać? 


\begin{tabular}{|c|l|c|c|c|}
\hline 42. & Czy, ogólnie rzecz biorac, ma Pan (i) zaufanie do: & tak & nie & $\begin{array}{c}\text { trudno } \\
\text { powiedzieć }\end{array}$ \\
\hline 1 & rodziny & & & \\
\hline 2 & sąsiadów & & & \\
\hline 3 & osób, z którymi pracuje na co dzień & & & \\
\hline 4 & obcych osób spotykanych w różnych sytuacjach życiowych & & & \\
\hline 5 & władz lokalnych gminy & & & \\
\hline 6 & $\begin{array}{l}\text { organizacji pozarządowych działających na terenie gminy } \\
\text { (np. stowarzyszeń, fundacji)? }\end{array}$ & & & \\
\hline 7 & lokalnych przedsiębiorców & & & \\
\hline
\end{tabular}

\begin{tabular}{|c|l|c|c|c|}
\hline 43. & $\begin{array}{l}\text { Czy, ogólnie rzecz biorac, ma Pan(i) zaufanie do osób, które } \\
\text { wchodza w sktad lokalnej grupy działania, a reprezentują: }\end{array}$ & tak & nie & $\begin{array}{c}\text { trudno } \\
\text { powiedzieć }\end{array}$ \\
\hline 1 & $\begin{array}{l}\text { sektor publiczny (np. samorząd gminy, Gminny Ośrodek } \\
\text { Kultury) }\end{array}$ & $\begin{array}{l}\text { sektor społeczny (np. organizacje pozarządowe, koła gospo- } \\
\text { dyń wiejskich }\end{array}$ & & \\
\hline 3 & sektor gospodarczy (np. lokalne firmy, rolnicy)? & & \\
\hline
\end{tabular}

44. W jakim stopniu interesuje się Pan(i) polityka:

1. bardzo dużym - śledzę prawie wszystko co się dzieje w polityce - prosze przejść do pytania $n r 46$

2. dużym - dość uważnie śledzę to co dzieje się w polityce - proszę przejść do pytania nr 46

3. średnim-śledzę jedynie główne wydarzenia polityce - proszę przejść do pytania nr 46

4. niewielkim- umykają uwadze nawet główne wydarzenia

5. w ogóle nie interesuję się tym, co się dzieje w polityce

45. Dlaczego nie interesuje się Pan(i) wcale polityka albo interesuje się nia tylko $w$ niewielkim stopniu?

46. Czy kiedykolwiek brat(a) Pan(i) udziat w przygotowywaniu kampanii wyborczej lub wykonywat jakieś prace na rzecz kandydata albo jakiejś partii/komitetu wyborczego?
1. tak
2. nie

47. Czy brat(a) Pan/i udziat w ostatnich wyborach:

1. prezydenckich 1 . tak 2 . nie

2. samorządowych 1 . tak 2 . nie

3. parlamentarnych 1 . tak 2 . Nie

48. Czy zastanawiat(a) się Pan/i kiedyś nad tym, aby kandydować w wyborach samorzadowych?
1. tak
2. nie 
49. Dlaczego?

50. Czy myślat(a) Pan(i) o objęciu funkcji wójta/burmistrza?
1. tak
2. nie

51. Czy zmienił(a)by Pan(i) coś w sposobie funkcjonowania władzy lokalnej?
1. tak
2. nie-proszę przejść do pyt.nr 53

52. Co przede wszystkim zmienił(a)by Pan(i) w sposobie funkcjonowania władzy lokalnej?

53. Na liście, która Panu(i) prezentujemy poniżej znajduja się różnego typu organizacje, stowarzyszenia, kluby zajmujące się działalnościa społeczna i/lub polityczną. Które z nich działają na terenie Pana(i) gminy? (wybraną odpowiedź proszę zaznaczyć X)

\begin{tabular}{|c|c|c|c|c|}
\hline Lp. & Typy organizacji & Tak & $\mathrm{Nie}$ & $\begin{array}{l}\text { Trudno } \\
\text { powiedzieć }\end{array}$ \\
\hline 1 & 2 & 3 & 4 & 5 \\
\hline 1 & $\begin{array}{l}\text { Organizacje działające na rzecz szkolnictwa, oświaty, np. komi- } \\
\text { tet rodzicielski, rada rodziców, fundacja szkolna, itp. }\end{array}$ & & & \\
\hline 2 & Organizacje kobiece, np. koła gospodyń wiejskich & & & \\
\hline 3 & Organizacje, ruchy religijne, kościelne, wspólnoty parafialne & & & \\
\hline 4 & $\begin{array}{l}\text { Organizacje, stowarzyszenia artystyczne, np. chór, orkiestra, } \\
\text { zespół taneczny, teatralny }\end{array}$ & & & \\
\hline 5 & $\begin{array}{l}\text { Ochotnicza Straż Pożarna, Górskie Ochotnicze Pogotowie } \\
\text { Ratunkowe itp. }\end{array}$ & & & \\
\hline 6 & $\begin{array}{l}\text { Organizacje charytatywne działające na rzecz potrzebujących } \\
\text { dzieci }\end{array}$ & & & \\
\hline 7 & Organizacje młodzieżowe, np. harcerstwo, kluby młodzieżowe & & & \\
\hline 8 & Organizacje, kluby i stowarzyszenia sportowe & & & \\
\hline 9 & Organizacje, stowarzyszenia turystyczne & & & \\
\hline 10 & $\begin{array}{l}\text { Komitety starające się o załatwienie jakiejś konkretnej sprawy } \\
\text { (np. wywozu śmieci, budowy drogi), grupy protestu }\end{array}$ & & & \\
\hline 11 & $\begin{array}{l}\text { Stowarzyszenia miłośników regionu, np. zajmujące się ochroną } \\
\text { zabytków, rozwojem kultury regionalnej itp. }\end{array}$ & & & \\
\hline
\end{tabular}




\begin{tabular}{|c|l|c|c|c|}
\hline 1 & \multicolumn{1}{|c|}{2} & 3 & 4 & 5 \\
\hline 12 & $\begin{array}{l}\text { Organizacje charytatywne działające na rzecz potrzebujących - } \\
\text { starych, ubogich, chorych, ofiar klęsk żywiołowych, itp. }\end{array}$ & & \\
\hline 13 & Organizacje emerytów, kluby seniorów & & \\
\hline 14 & Towarzystwa przyjaźni z innymi krajami, narodami & $\begin{array}{l}\text { Stowarzyszenia, związki działkowiczów, hodowców, wędkarzy, } \\
\text { zbieraczy, kolekcjonerów, hobbystów }\end{array}$ & & \\
\hline 16 & Partie lub stowarzyszenia polityczne & $\begin{array}{l}\text { Organizacje samopomocowe, kluby wsparcia np. stowarzysze- } \\
\text { nia osób niepełnosprawnych, samotnych matek, osób bezrobot- } \\
\text { nych itp. }\end{array}$ & & \\
\hline 18 & Organizacje działające na rzecz ochrony środowiska naturalnego & & & \\
\hline 20 & Inne organizacje, stowarzyszenia, ruchy, kluby lub fundacje & & & \\
\hline
\end{tabular}

54. Czy w któreś z wyżej wymienionych organizacji aktywnie Pan(i) działa?
1. tak
2. nie-proszę przejść do pytania nr56

55. W której/których organizacjach i stowarzyszeniach Pan(i) działa?- proszę napisać używajac numeracji z tabeli

56. Czy kiedykolwiek zgłaszał(a) Pan(i) osobiście lub w porozumieniu z innymi mieszkańcami Pana(i) miejscowości/gminy przedstawicielom władz lokalnych jakieś postulaty, prośby czy żądania?

1. tak, osobiście

2. tak, wspólnie z innymi mieszkańcami

3. nie, nigdy nie zgłaszałem(am) żadnych postulatów czy żądań

57. Czy sami mieszkańcy Pana(i) miejscowości/gminy kiedykolwiek organizowali jakieś akcje czy protesty, aby zrealizować wspólny interes czy rozwiąać wspólny problem?

1. tak - zarówno akcje, jak i protesty

2. tak - tylko akcje

3. tak - tylko protesty

4. nie, nie organizowali ani akcji ani protestów

58. Czy rozwiąywaniem problemów wsi/gminy, w której Pan(i) mieszka powinni zajmować się przede wszystkim:

1. sami mieszkańcy

2. ludzie tacy, jak Pan(i)

3. mieszkańcy przy pomocy władz lokalnych

4. władze lokalne przy pomocy mieszkańców

5. władze lokalne przy pomocy mieszkańców i osób takich jak Pan(i)

6. same władze lokalne, ponieważ do tego zostały powołane 
59. Jak Pan(i) sądzi, czy działania osób takich, jak Pan(i), moga doprowadzić do rozwiązania niektórych problemów swojego środowiska, przyczynić się do tego, żeby sytuacja w Pana(i) miejscowości/gminie zmieniła się na lepsze?

1. zdecydowanie tak

2. raczej tak

3. zależy w jakiej sprawie

4. raczej nie

5. zdecydowanie nie

60. Jaki wedlug Pana(i) wplyw na decyzje władz lokalnych dotyczace tego, co dzieje się w Pana(i) miejscowości i/lub gminie maja takie osoby jak Pan(i)?

1. bardzo duży

2. raczej duży

3. przeciętny- ani mały ani duży

4. raczej mały

5. żaden-w ogóle nie mają wpływu

61. A jak Pan(i) sądzi, czyje przede wszystkim oczekiwania i interesy reprezentuje większość radnych w Pana(i) gminie?

1. oczekiwania i interesy wszystkich mieszkańców gminy

2. oczekiwania i interesy osób, które na nich głosowały

3. oczekiwania i interesy swojej partii

4. oczekiwania i interesy krewnych i znajomych

5. własne oczekiwania i interesy

62. Jak Pan(i) sądzi, czy ludzie chętniej angażują się w działania na rzecz swojej miejscowości:

1. kiedy chcą, aby na jej terenie lub gminy zostały zbudowane nowe, ważne dla mieszkańców obiekty, np. drogi, kanalizacja, obiekty kulturalne czy też,

2. kiedy chcą, aby jej terenie lub gminy nie powstały obiekty, które przeszkadzają mieszkańcom, np. autostrady, spalarnie śmieci, maszty telefonii komórkowej itp.

63. Co Pana(i) zdaniem jest najważniejsze dla rozwoju polskiej wsi (proszę wskazać wszystkie prawdziwe odpowiedzi):

1. rolnictwo

2. działalność gospodarcza nie związana z rolnictwem

3. inne, jakie.

64. Czy Pana(i) zdaniem rozwój rolnictwa jest przyszłością dla polskiej wsi czy raczej jego znaczenie dla rozwoju wsi będzie malało?

1. rolnictwo jest przyszłością polskiej wsi

2. znaczenie rolnictwa dla rozwoju wsi będzie malało

65. Czy spotkat (a) się Pan(i) kiedyś z terminem rozwój wielofunkcyjny?

1. tak

2. nie-proszę przejść do pytania nr 67

66. Co Pan(i) zdaniem oznacza ten termin? 
67. Czy spotkat się Pan(i) z terminem rozwój zrównoważony?

1. tak 2. nie-proszę przejść do pyt. $n r M 1$

68. Co Pan(i) zdaniem oznacza ten termin?

\section{METRYCZKA}

M1. W którym roku się Pan(i) urodził(a)?

M2. Proszę wskazać swoja pteć.

1. kobieta

2. mężczyzna

M3. Czy mieszka Pan(i) na terenie gminy od urodzenia?

1. tak

2. nie

M4. Jakie jest Pana(i) wykształcenie?

1. nieukończone podstawowe

2. podstawowe

3. zasadnicze zawodowe

4. niepełne średnie

5. średnie

6. pomaturalne

7. nieukończone wyższe

8. wyższe

M5. Czy obecnie jest Pan(i) osoba pracujaca?

1. tak-proszę przejść do M7

2. nie

M6. Jaki jest Pana(i) obecny status?

1. niepracujący emeryt - proszę przejść do pytania nr M10

2. niepracujący rencista-proszę przejść do pytania nr M10

3. osoba ucząca się, niepracująca - proszę przejść do pytania nr M10

4. osoba bezrobotna-prosze przejść do pytania $n r M 8$

M7. Czy obecnie pracuje Pan(i) poza rolnictwem?

1. tak

2. nie

M8. Do jakiej kategorii społeczno-zawodowej przede wszystkim zaliczył(a)by Pan(i) siebie?

1. kadry kierownicze

2. specjaliści (managerowie, inteligencja) 
3. pracownicy umysłowi średniego szczebla

4. pracownicy fizyczni

5. właściciele gospodarstw rolnych

6. właściciele firm

M9. $C z y L G D$, w której pracach Pan(i) uczestniczy powstała na skutek realizacji schematu I Pilotażowego Programu LEADER+?
1. tak
2. nie

Bardzo dziękujemy za poświęcony czas i udzielone informacje. 
Załącznik 2. Karta opisu aktywności społecznej na obszarze jednostek samorządu terytorialnego wchodzących w skład lokalnej grupy działania

\begin{tabular}{|c|c|l|l|l|l|l|}
\hline $\begin{array}{c}\text { Wojewódz- } \\
\text { two }\end{array}$ & $\begin{array}{c}\text { Nazwa } \\
\text { partnerstwa }\end{array}$ & $\begin{array}{c}\text { Nazwa } \\
\text { gminy }\end{array}$ & Powiat & $\begin{array}{c}\text { Liczba KGW } \\
\text { na obszarze } \\
\text { gminy (2010) }\end{array}$ & $\begin{array}{c}\text { Lliczba OSP } \\
\text { na obszarze } \\
\text { gminy (2010) }\end{array}$ & $\begin{array}{c}\text { Stowarzysze- } \\
\text { nia, fundacje } \\
\text { i organizacje } \\
\text { społeczne } \\
\text { zarejestrowane } \\
\text { w REGON }\end{array}$ \\
\hline & & & & & & \\
\hline & & & & & & \\
\hline & & & & & & \\
\hline & & & & & & \\
\hline & & & & & & \\
\hline & & & & & & \\
\hline
\end{tabular}

Załącznik 3. Karta opisu aktywności gospodarczej na obszarze jednostek samorządu terytorialnego wchodzących w skład lokalnej grupy działania

\begin{tabular}{|c|c|c|c|c|c|c|c|c|}
\hline $\begin{array}{c}\text { Wojewódz- } \\
\text { two }\end{array}$ & $\begin{array}{c}\text { Nazwa } \\
\text { partnerstwa }\end{array}$ & $\begin{array}{l}\text { Nazwa } \\
\text { gminy }\end{array}$ & Powiat & $\begin{array}{c}\text { Średnia } \\
\text { wielkość } \\
\text { gospo- } \\
\text { darstw } \\
\text { rolnych na } \\
\text { obszarze } \\
\text { gminy } \\
(2010)\end{array}$ & $\begin{array}{c}\text { Udział } \\
\text { bezro- } \\
\text { botnych } \\
\text { (z terenu } \\
\text { gminy) } \\
\text { w liczbie } \\
\text { ludności } \\
\text { w wieku } \\
\text { produk- } \\
\text { cyjnym } \\
\text { (w \%) }\end{array}$ & $\begin{array}{l}\text { Liczba } \\
\text { grup pro- } \\
\text { ducentów } \\
\text { rolnych } \\
\text { (na obsza- } \\
\text { rze gminy) } \\
(2010)\end{array}$ & \begin{tabular}{|} 
Liczba go- \\
spodarstw \\
prowadzą- \\
cych dzia- \\
łalność \\
wyłącznie \\
pozarol- \\
niczą na \\
obszarze \\
gminy \\
$(2010)$
\end{tabular} & \begin{tabular}{|c} 
Liczba \\
firm (na \\
obszarze \\
gminy) \\
prowadzo- \\
nych przez \\
osoby \\
fizyczne \\
poza \\
sektorem \\
rolnym \\
$(2010)$
\end{tabular} \\
\hline & & & & & & & & \\
\hline & & & & & & & & \\
\hline & & & & & & & & \\
\hline & & & & & & & & \\
\hline & & & & & & & & \\
\hline & & & & & & & & \\
\hline
\end{tabular}


Załącznik 4. Karta najważniejszych projektów realizowanych przez lokalne grupy działania

\begin{tabular}{|c|c|c|c|c|c|}
\hline $\begin{array}{c}\text { Wojewódz- } \\
\text { two }\end{array}$ & $\begin{array}{c}\text { Nazwa } \\
\text { LGD } \\
\text { realizowane/zreali- } \\
\text { zowane z PO KL } \\
(2007-2013)\end{array}$ & $\begin{array}{c}\text { Projekty } \\
\text { współpracy } \\
\text { z PROW }\end{array}$ & $\begin{array}{c}\text { Projekty realizo- } \\
\text { wane ze środków } \\
\text { innych niż PROW } \\
\text { (FIO, Akademia } \\
\text { Rozwoju Filantro- } \\
\text { pii itp.) }\end{array}$ & Suma \\
\hline & & & & & \\
\hline & & & & & \\
\hline & & & & & \\
\hline & & & & & \\
\hline & & & & & \\
\hline
\end{tabular}




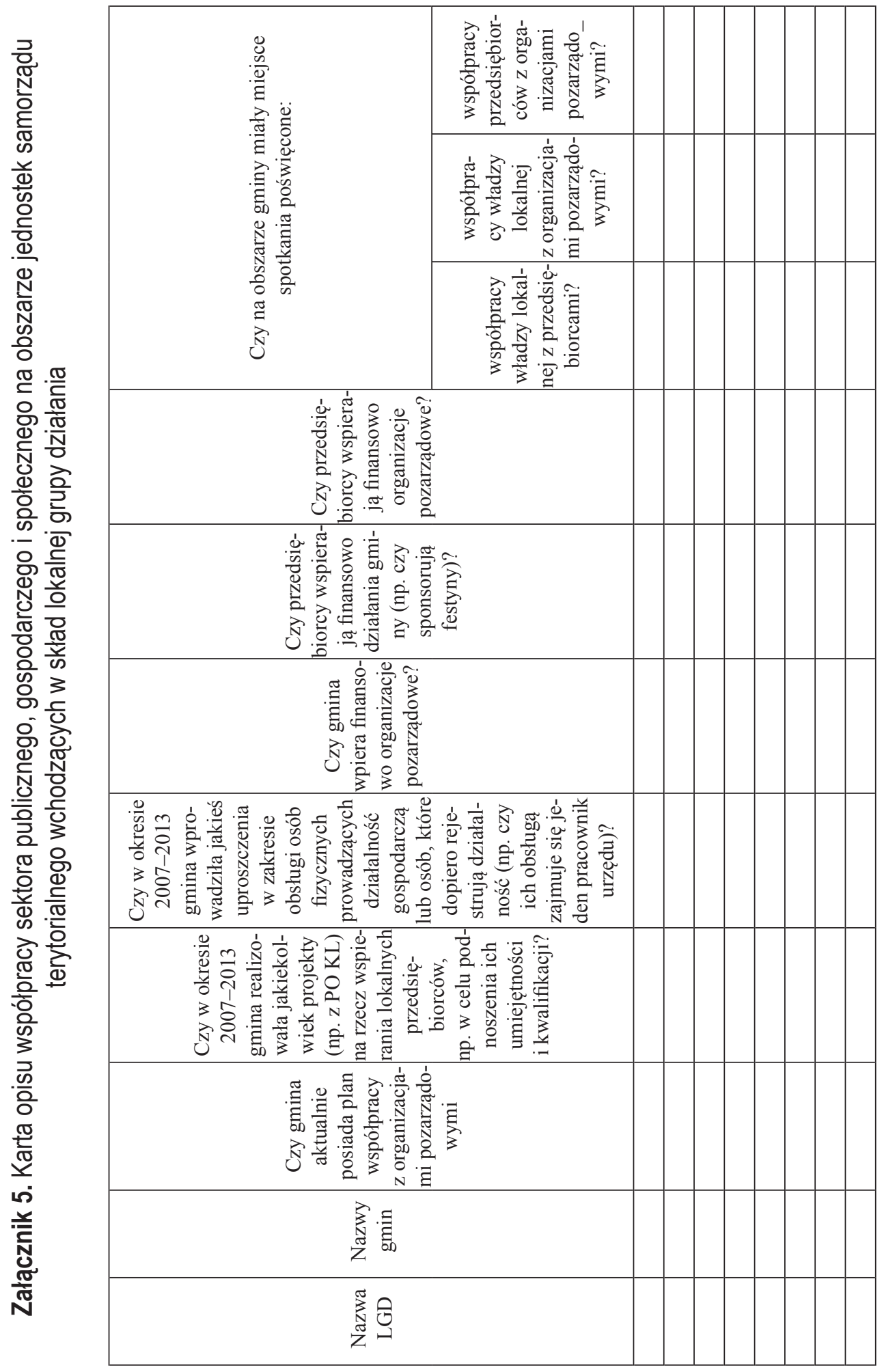


Załącznik 6. Najważniejsze projekty realizowane przez lokalne grupy działania

\begin{tabular}{|c|c|c|c|c|c|}
\hline $\begin{array}{c}\text { Woje- } \\
\text { wództwo }\end{array}$ & Nazwa LGD & $\begin{array}{l}\text { Projekty realizowane/ } \\
\text { zrealizowane z POKL } \\
\quad(2007-2013)\end{array}$ & $\begin{array}{l}\text { Projekty } \\
\text { współpracy } \\
\text { z PROW }\end{array}$ & $\begin{array}{c}\text { Projekty realizowane } \\
\text { ze środków innych } \\
\text { niż PROW (FIO, } \\
\text { Akademia Rozwoju } \\
\text { Filantropii itp.) }\end{array}$ & Suma \\
\hline 1 & 2 & 3 & 4 & 5 & 5 \\
\hline \multirow{11}{*}{ lubuskie } & $\begin{array}{l}\text { Region } \\
\text { Kozła }\end{array}$ & - & $\begin{array}{c}\text { "Powstanie } \\
\text { Wielkopol- } \\
\text { skie 1918/19" }\end{array}$ & - & 1 \\
\hline & \multirow{9}{*}{$\begin{array}{c}\text { Porozumie- } \\
\text { nie Wzgórz } \\
\text { Dałkow- } \\
\text { skich }\end{array}$} & $\begin{array}{c}\text { „Zostań instruktorem } \\
\text { edukacji regionalnej } \\
\text { po Wzgórzach } \\
\text { Dałkowskich” }\end{array}$ & \multirow{9}{*}{-} & „AGRAFKA” & \multirow{9}{*}{16} \\
\hline & & $\begin{array}{l}\text { „Przedszkolandia } \\
\text { na Wzgórzach } \\
\text { Dałkowskich" }\end{array}$ & & $\begin{array}{c}\text { „Lubuskie Centrum } \\
\text { Wspierania Organiza- } \\
\text { cji Pozarządowych” }\end{array}$ & \\
\hline & & $\begin{array}{c}\text { „Babska akademia czyli } \\
\text { gotowanie } \\
\text { i dekorowanie" }\end{array}$ & & „Działaj Lokalnie” & \\
\hline & & $\begin{array}{l}\text { „Krok po kroku przy- } \\
\text { rządzanie, czyli proste } \\
\text { gotowanie” }\end{array}$ & & $\begin{array}{c}\text { „Lekcje w przyrodzie } \\
\text { na Wzgórzach Dał- } \\
\text { kowskich" }\end{array}$ & \\
\hline & & $\begin{array}{c}\text { „Oddolne inicjatywy } \\
\text { edukacyjne na obszarach } \\
\text { wiejskich Wzgórz } \\
\text { Dałkowskich" }\end{array}$ & & $\mid \begin{array}{c}\text { „Babska Akademia } \\
\text { - czyli Metamorfoza” }\end{array}$ & \\
\hline & & $\begin{array}{l}\text { „Wykwalifikowany strażak } \\
\text { gwarantem bezpieczeń- } \\
\text { stwa na Wzgórzach } \\
\text { Dałkowskich” }\end{array}$ & & $\begin{array}{l}\text { „Historie drzewami } \\
\text { pisane" }\end{array}$ & \\
\hline & & $\begin{array}{c}\text { „Oddolne inicjatywy } \\
\text { edukacyjne na obszarach } \\
\text { wiejskich Wzgórz } \\
\text { Dałkowskich. II edycja” }\end{array}$ & & \multirow{3}{*}{$\begin{array}{c}\text { „Sukces w spódnicy } \\
\text { - czyli babski leader- } \\
\text { ship w praktyce” }\end{array}$} & \\
\hline & & $\begin{array}{c}\text { „Włącz się do dialogu } \\
\text { - z liderami zbudujemy } \\
\text { lepsze jutro" }\end{array}$ & & & \\
\hline & & $\begin{array}{c}\text { „Atrakcyjny zawodowo } \\
\text { na Wzgórzach } \\
\text { Dałkowskich" }\end{array}$ & & & \\
\hline & $\begin{array}{l}\text { Fundacja } \\
\text { Zielonej } \\
\text { Doliny Odry } \\
\text { i Warty }\end{array}$ & - & $\begin{array}{c}\text { „Hydroinży- } \\
\text { nieria } \\
\text { Doliny Dol- } \\
\text { nej Warty" }\end{array}$ & $\begin{array}{c}\text { „Program współpracy } \\
\text { transgranicznej” }\end{array}$ & 2 \\
\hline
\end{tabular}




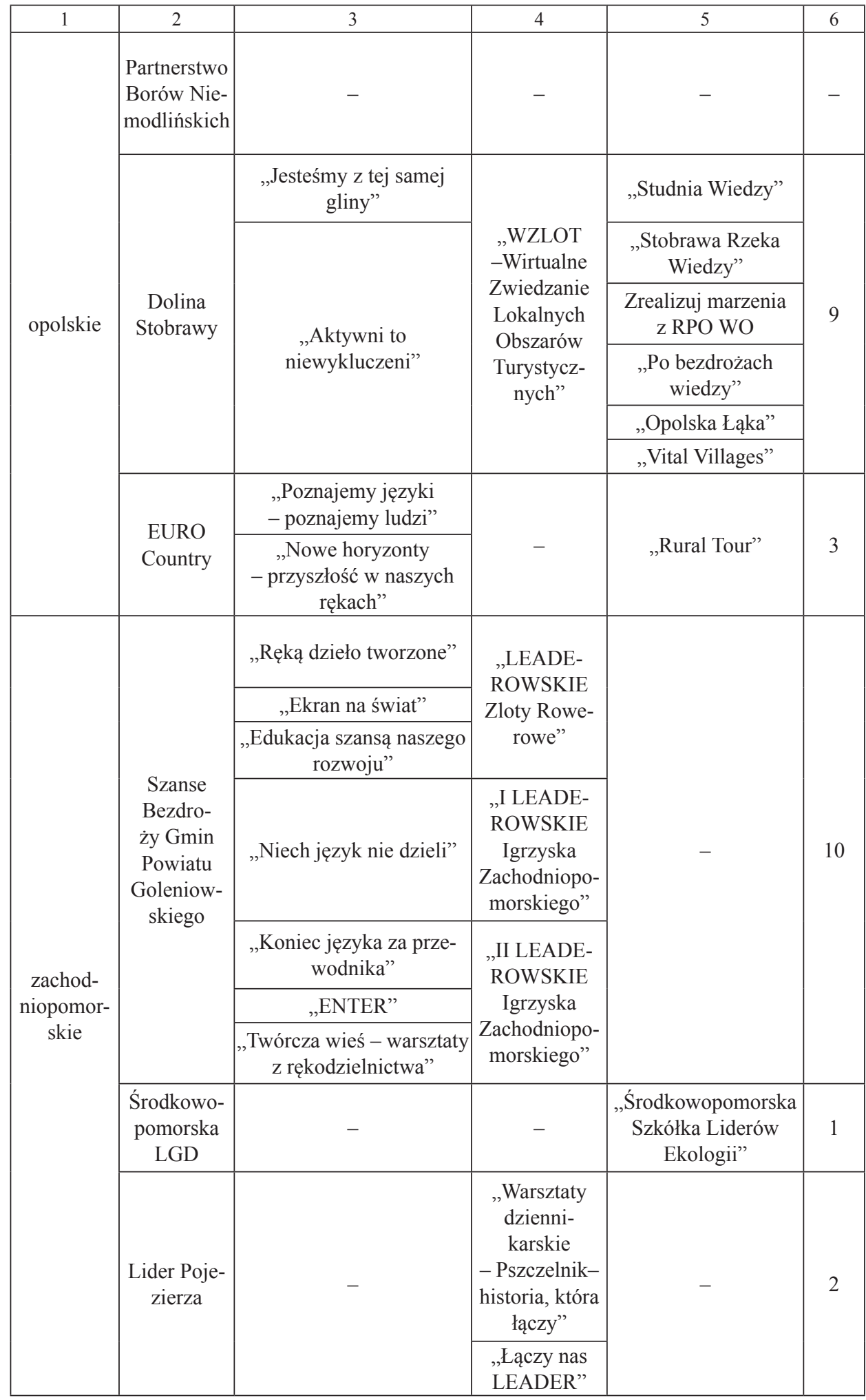


Załącznik 6 (cd.)

\begin{tabular}{|c|c|c|c|c|c|}
\hline 1 & 2 & 3 & 4 & 5 & 6 \\
\hline \multirow{8}{*}{$\begin{array}{l}\text { małopol- } \\
\text { skie }\end{array}$} & \multirow{4}{*}{$\begin{array}{l}\text { Dunajec- } \\
\text { Biała }\end{array}$} & \multirow{4}{*}{-} & „Smak na produkt” & \multirow{4}{*}{$\begin{array}{l}\text { „Włącznik } \\
\text { - uruchomić } \\
\text { wolontariat" }\end{array}$} & \multirow{4}{*}{5} \\
\hline & & & $\begin{array}{l}\text { „Produkt lokalny szansą } \\
\text { rozwoju regionu" }\end{array}$ & & \\
\hline & & & $\begin{array}{c}\text { „Turystyka Wiejska } \\
\text { w Europie Środkowej” }\end{array}$ & & \\
\hline & & & „Wiejski Szlak Europy” & & \\
\hline & $\begin{array}{l}\text { PROKOPA- } \\
\text { RA }\end{array}$ & - & - & $\begin{array}{l}\text { „Rowerowy Szlak } \\
\text { Kościuszkowski” }\end{array}$ & 1 \\
\hline & \multirow[b]{2}{*}{$\begin{array}{l}\text { Dolina } \\
\text { Karpia }\end{array}$} & \multirow[b]{2}{*}{-} & „Smak na produkt” & \multirow[b]{2}{*}{-} & \multirow[b]{2}{*}{2} \\
\hline & & & $\begin{array}{l}\text { „Północnozachodnia } \\
\text { Małopolska - Lubię to” }\end{array}$ & & \\
\hline & Jaksa & - & - & $\begin{array}{l}\text { „Rowerowy Szlak } \\
\text { Kościuszkowski”" }\end{array}$ & 1 \\
\hline \multirow{4}{*}{$\begin{array}{l}\text { wielkopol- } \\
\text { skie }\end{array}$} & $\begin{array}{l}\text { Ostrzeszow- } \\
\text { ska LGD }\end{array}$ & - & $\begin{array}{l}\text { „Rowerowa Pętla Połu- } \\
\text { dniowej Wielkopolski” }\end{array}$ & - & 1 \\
\hline & \multirow[b]{3}{*}{ KOLD } & \multirow{3}{*}{$\begin{array}{l}\text { „Z Internetem } \\
\text { w przyszłość” }\end{array}$} & $\begin{array}{l}\text { „Powstanie Wielkopol- } \\
\text { skie - 1918/19” }\end{array}$ & \multirow[b]{3}{*}{-} & \multirow[b]{3}{*}{4} \\
\hline & & & $\begin{array}{c}\text { „Wykorzystanie potencja- } \\
\text { łu w turystyce wiejskiej } \\
\text { w obszarze Fläming - } \\
\text { Havel” }\end{array}$ & & \\
\hline & & & $\begin{array}{l}\text { „Rozwój turystyki wiej- } \\
\text { skiej z wykorzystaniem } \\
\text { zwyczajów lokalnych } \\
\text { w obszarach Estonia } \\
\text { - North Harju, Litwa - } \\
\text { Suduva, Polska - KOLD, } \\
\text { Słowacja - Spis” }\end{array}$ & & \\
\hline \multirow{4}{*}{$\begin{array}{l}\text { podkar- } \\
\text { packie }\end{array}$} & $\begin{array}{l}\text { Subregion } \\
\text { Magurski }\end{array}$ & - & - & $\begin{array}{l}\text { „Program Integracji } \\
\text { Społecznej” }\end{array}$ & 1 \\
\hline & Lasovia & - & „Szlakami Lasowiaków” & - & 1 \\
\hline & $\begin{array}{c}\text { CK Podkar- } \\
\text { pacie }\end{array}$ & - & - & - & - \\
\hline & $\begin{array}{l}\text { Partnerstwo } \\
\text { dla Ziemi } \\
\text { Niżańskiej }\end{array}$ & - & $\begin{array}{l}\text { „Ekomuzeum w widłach } \\
\text { Wisły i Sanu” }\end{array}$ & $\begin{array}{l}\text { „Kurs podstawowy } \\
\text { płetwonurka" }\end{array}$ & 2 \\
\hline
\end{tabular}

Źródło: opracowanie własne. 
Załącznik 7. Tabele dotyczące rozdziału 2.2

Tabela 7.1. Poziom zainteresowania polityką wg płci

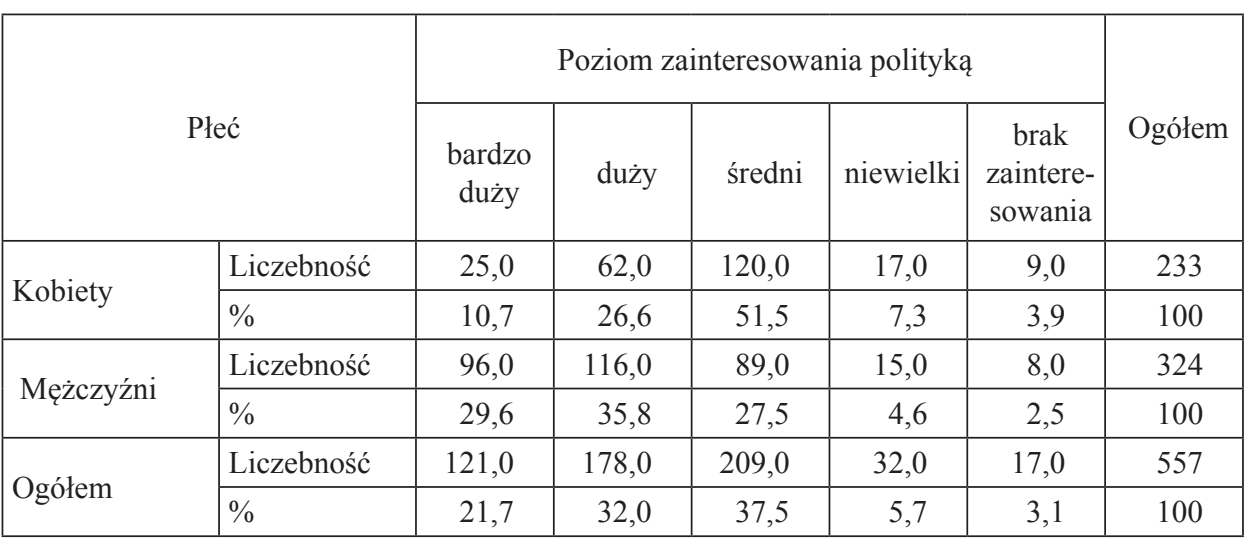

Źródło: opracowanie własne.

Tabela 7.2. Poziom zainteresowania polityką wg wieku

\begin{tabular}{|c|c|c|c|c|c|c|c|}
\hline \multirow{2}{*}{\multicolumn{2}{|c|}{ Wiek }} & \multicolumn{5}{|c|}{ Poziom zainteresowania polityką } & \multirow{3}{*}{$\begin{array}{r}\text { Ogółem } \\
6,0\end{array}$} \\
\hline & & \multirow{2}{*}{$\begin{array}{r}\begin{array}{r}\text { bardzo } \\
\text { duży }\end{array} \\
1,0\end{array}$} & \multirow{2}{*}{$\begin{array}{r}\text { duży } \\
0\end{array}$} & \multirow{2}{*}{$\begin{array}{r}\text { średni } \\
2,0\end{array}$} & \multirow{2}{*}{$\begin{array}{c}\text { niewielki } \\
0\end{array}$} & \multirow{2}{*}{$\begin{array}{c}\begin{array}{c}\text { brak } \\
\text { zaintere- } \\
\text { sowania }\end{array} \\
3,0\end{array}$} & \\
\hline \multirow{2}{*}{ 18-24lat } & Liczebność & & & & & & \\
\hline & $\%$ & 16,7 & 0 & 33,3 & 0 & 50,0 & 100,0 \\
\hline \multirow{2}{*}{ 25-34 lat } & Liczebność & 13,0 & 17,0 & 36,0 & 3,0 & 7,0 & 76,0 \\
\hline & $\%$ & 17,1 & 22,4 & 47,4 & 3,9 & 9,2 & 100,0 \\
\hline \multirow{2}{*}{$35-44$ lat } & Liczebność & 13,0 & 39,0 & 54,0 & 6,0 & 1,0 & 113,0 \\
\hline & $\%$ & 11,5 & 34,5 & 47,8 & 5,3 & 9,0 & 100,0 \\
\hline \multirow{2}{*}{$45-54$ lat } & Liczebność & 33,0 & 53,0 & 56,0 & 12,0 & 2,0 & 156,0 \\
\hline & $\%$ & 21,2 & 34,0 & 35,9 & 7,7 & 1,3 & 100,0 \\
\hline \multirow{2}{*}{ 55-64 lat } & Liczebność & 40,0 & 44,0 & 39,0 & 5,0 & 3,0 & 131,0 \\
\hline & $\%$ & 30,5 & 33,6 & 29,8 & 3,8 & 2,3 & 100,0 \\
\hline \multirow{2}{*}{$65+$} & Liczebność & 14,0 & 12,0 & 8,0 & 3,0 & 0 & 54,0 \\
\hline & $\%$ & 37,8 & 32,4 & 21,6 & 8,1 & 0 & 199,8 \\
\hline \multirow{2}{*}{ Ogółem } & Liczebność & 114,0 & 165,0 & 195,0 & 29,0 & 16,0 & 519,0 \\
\hline & $\%$ & 22,0 & 31,8 & 37,6 & 5,6 & 3,1 & 100,0 \\
\hline
\end{tabular}

Źródło: opracowanie własne. 
Tabela 7.3. Poziom zainteresowania polityką wg wykształcenia

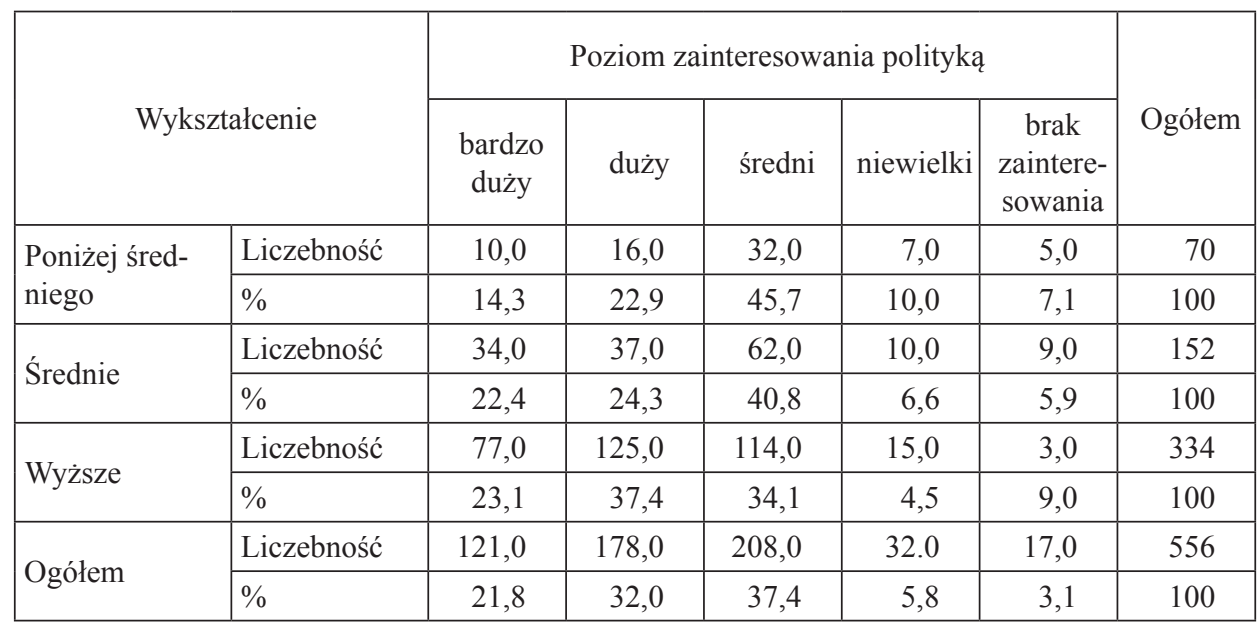

Źródło: opracowanie własne.

Tabela 7.4. Poziom zainteresowania polityką wg kategorii zawodowych

\begin{tabular}{|c|c|c|c|c|c|c|c|}
\hline & & & ziom z & teresow & nia polityką & & \\
\hline Kategoria zawodov & & & & & & & Ogółem \\
\hline Kadrv kierownicze & $\mathrm{L}$. & 38,0 & 34,0 & 22,0 & 1,0 & 0 & 95 \\
\hline 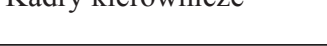 & $\%$ & 40,0 & 35,8 & 23,2 & 1,1 & 0 & 100 \\
\hline Snecialiści (intelioncia) & L. & 16,0 & 34,0 & 28,0 & 4,0 & 1,0 & 83 \\
\hline specjantser (mimengencja) & $\%$ & 19,3 & 41,0 & 33,7 & 4,8 & 1,2 & 100 \\
\hline Pracownicy umysłowi & $\mathrm{L}$. & 28,0 & 48,0 & 70,0 & 13,0 & 4,0 & 163 \\
\hline (biurowi, handlu i usług) & $\%$ & 17,2 & 29,4 & 42,9 & 8,0 & 2,5 & 100 \\
\hline Pracownicy fizyczni & L. & 8,0 & 8,0 & 10,0 & 1,0 & 1,0 & 28 \\
\hline & $\%$ & 28,6 & 28,6 & 35,7 & 3,6 & 3,6 & 100 \\
\hline Właściciele gospodarstw & L. & 4,0 & 4,0 & 16,0 & 3,0 & 0 & 27 \\
\hline rolnych & $\%$ & 14,8 & 14,8 & 59,3 & 11,1 & 0 & 100 \\
\hline 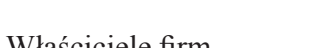 & $\mathrm{L}$. & 7,0 & 13,0 & 21,0 & 2,0 & 0 & 43 \\
\hline Wrascicieie inm & $\%$ & 16,3 & 30,2 & 48,8 & 4,7 & 0 & 100 \\
\hline Og & L. & 101,0 & 141,0 & 167,0 & 24,0 & 6,0 & 439 \\
\hline & $\%$ & 23,0 & 32,1 & 38,0 & 5,5 & 1,4 & 100 \\
\hline
\end{tabular}

Źródło: opracowanie własne. 
Tabela 7.5. Opinie na temat tego, czyje oczekiwania interesy reprezentują radni wg płci

\begin{tabular}{|l|l|c|c|c|c|c|}
\hline \multicolumn{2}{|c|}{ Płeć } & \multicolumn{3}{|c|}{ Opinia na temat tego czyje oczekiwania interesy reprezentują radni } \\
\cline { 3 - 7 } & & $\begin{array}{c}\text { wszystkich } \\
\text { mieszkańców } \\
\text { gminy }\end{array}$ & $\begin{array}{c}\text { osób, które } \\
\text { na nich } \\
\text { głosowały }\end{array}$ & swojej partii & $\begin{array}{c}\text { krewnych } \\
\text { i znajomych }\end{array}$ & własne \\
\hline \multirow{2}{*}{ Kobiety } & L. & 57,0 & 46,0 & 28,0 & 8,0 & 25,0 \\
\cline { 2 - 7 } & $\%$ & 34,8 & 28,0 & 17,1 & 4,9 & 15,2 \\
\hline \multirow{2}{*}{ Mężczyźni } & L. & 84,0 & 62,0 & 34,0 & 8,0 & 26,0 \\
\cline { 2 - 7 } & $\%$ & 39,3 & 29,0 & 15,9 & 3,7 & 12,1 \\
\hline
\end{tabular}

Źródło: opracowanie własne.

Tabela 7.6. Opinia na temat tego, czyje przede wszystkim oczekiwania $\mathrm{i}$ interesy reprezentują radni wg wieku

\begin{tabular}{|c|c|c|c|c|c|c|}
\hline & & Opin & a na temat te & o czyje interes & reprezentują & \\
\hline & & wszystkich & osób, które & 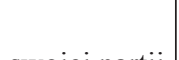 & krewnych & 1 \\
\hline $10 \Omega 11$ & L. & 0 & 2,0 & 0 & 0 & 0 \\
\hline & $\%$ & 0 & 100,0 & 0 & 0 & 0 \\
\hline $25=241 \mathrm{t}$ & L. & 8,0 & 18,0 & 9,0 & 2,0 & 10,0 \\
\hline $20-34$ lal & $\%$ & 17,0 & 38,3 & 19,1 & 4,3 & 21,3 \\
\hline $25 \quad 441 \mathrm{~b}$ & L. & 28,0 & 19,0 & 15,0 & 3,0 & 8,0 \\
\hline $3 J-44$ lât & $\%$ & 38,4 & 26,0 & 20,5 & 4,1 & 11,0 \\
\hline $45 \quad 541 \mathrm{~b}$ & L. & 42,0 & 30,0 & 21,0 & 3,0 & 13,0 \\
\hline $4 J-34$ Ial & $\%$ & 38,5 & 27,5 & 19,3 & 2,8 & 11,9 \\
\hline 55 & L. & 35,0 & 28,0 & 12,0 & 5,0 & 14,0 \\
\hline $\mathrm{JJ}-04 \mathrm{lal}$ & $\%$ & 37,2 & 29,8 & 12,8 & 5,3 & 14,9 \\
\hline 65 & L. & 12,0 & 6,0 & 2,0 & 2,0 & 2,0 \\
\hline OJT lat & $\%$ & 50,0 & 25,0 & 8,3 & 8,3 & 8,3 \\
\hline
\end{tabular}

Źródło: opracowanie własne. 
Tabela 7.7. Opinie na temat tego czyje przede wszystkim oczekiwania i interesy reprezentują radni wg wykształcenia

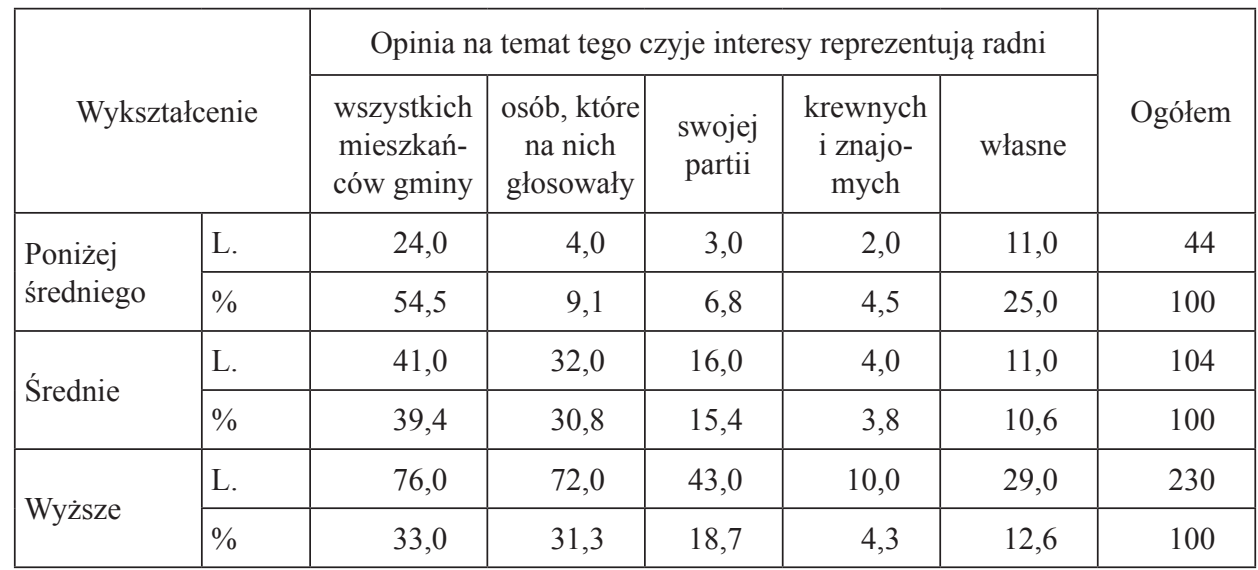

Źródło: opracowanie własne.

Tabela 7.8. Opinie na temat tego czyje przede wszystkim oczekiwania i interesy reprezentują radni wg kategorii zawodowych

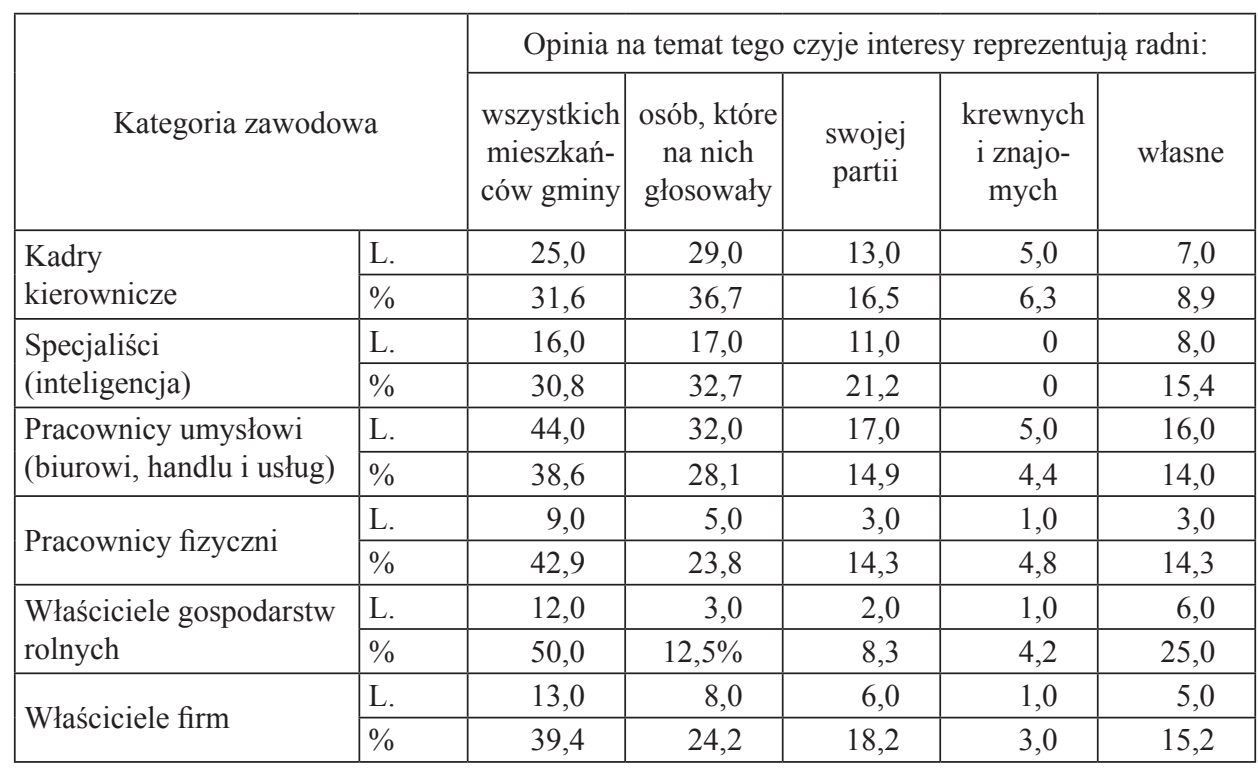

Źródło: opracowanie własne. 
Tabela 7.9. Przekonanie o potrzebie wprowadzenia zmian w funkcjonowaniu władzy lokalnej wg kategorii zawodowych

\begin{tabular}{|l|l|r|r|r|}
\hline \multicolumn{2}{|c|}{ Kategoria zawodowa } & $\begin{array}{r}\text { Przekonanie o potrzebie } \\
\text { wprowadzenia zmian } \\
\text { w funkcjonowanie } \\
\text { władzy lokalnej }\end{array}$ & \multirow{2}{*}{ Ogółem } \\
\cline { 3 - 5 } \multicolumn{2}{|l|}{} & $\begin{array}{r}\text { tak } \\
\text { nie }\end{array}$ & \\
\cline { 2 - 5 } Kadry kierownicze & Liczebność & 42,0 & 53,0 & 95 \\
\cline { 2 - 5 } & $\%$ & 44,2 & 55,8 & 100 \\
\hline \multirow{2}{*}{ Specjaliści (inteligencja) } & Liczebność & 51,0 & 31,0 & 82 \\
\cline { 2 - 5 } & $\%$ & 62,2 & 37,8 & 100 \\
\hline \multirow{2}{*}{$\begin{array}{l}\text { Pracownicy umysłowi (biurowi, } \\
\text { handlu i usług) }\end{array}$} & Liczebność & 66,0 & 94,0 & 160 \\
\hline \multirow{2}{*}{ Pracownicy fizyczni } & $\%$ & 41,3 & 58,8 & 100 \\
\hline \multirow{2}{*}{ Właściciele gosp. rolnych } & Liczebność & 7,0 & 21,0 & 28 \\
\cline { 2 - 5 } & $\%$ & 25,0 & 75,0 & 100 \\
\hline \multirow{2}{*}{ Właściciele firm } & Liczebność & 16,0 & 11,0 & 27 \\
\cline { 2 - 5 } & $\%$ & 59,3 & 40,7 & 100 \\
\hline \multirow{2}{*}{ Ogółem } & Liczebność & 21,0 & 22,0 & 43 \\
\cline { 2 - 5 } & $\%$ & 48,8 & 51,2 & 100 \\
\hline & Liczebność & 203,0 & 232,0 & 435 \\
\cline { 2 - 5 } & $\%$ & 46,7 & 53,3 & 100 \\
\hline
\end{tabular}

Tabela 7.10. Opinie na temat tego, kto powinien przede wszystkim rozwiązywać problemy wsi/gminy wg wykształcenia

\begin{tabular}{|c|c|c|c|c|c|c|c|c|}
\hline & & & Kto powi & ien rozwi & ązywać pr & oblemy gminy & & \\
\hline Wyksztal & enie & & ludzie & $\begin{array}{l}\text { miesz- } \\
\text { kańcy }\end{array}$ & $\begin{array}{l}\text { władze } \\
\text { lok. } \\
\text { przy }\end{array}$ & $\begin{array}{c}\text { władze przy } \\
\text { pomocy }\end{array}$ & same & Ogółem \\
\hline Poniżej & $\mathrm{L}$. & 3,0 & 1,0 & 12,0 & 24,0 & 9,0 & 22,0 & 71 \\
\hline średniego \% & 4,2 & 1,4 & 16,9 & 33,8 & 12,7 & 31,0 & 100,0 & 100 \\
\hline Średnie & L. & 8,0 & 3,0 & 42,0 & 50,0 & 31,0 & 14,0 & 148 \\
\hline$\%$ & 5,4 & 2,0 & 28,4 & 33,8 & 20,9 & 9,5 & 100,0 & 100 \\
\hline Wyższe & L. & 23,0 & 5,0 & 78,0 & 122,0 & 92,0 & 9,0 & 329 \\
\hline$\%$ & 7,0 & 1,5 & 23,7 & 37,1 & 28,0 & 2,7 & 100,0 & 100 \\
\hline & L. & 34,0 & 9,0 & 132,0 & 196,0 & 132,0 & 45,0 & 548 \\
\hline Ugote & $\%$ & 6,2 & 1,6 & 24,1 & 35,8 & 24,1 & 8,2 & 100 \\
\hline
\end{tabular}

Źródło: opracowanie własne. 
Tabela 7.11. Opinie na temat tego kto powinien rozwiązywać problemy wsi/gminy wg kategorii zawodowych

\begin{tabular}{|c|c|c|c|c|c|c|c|c|}
\hline & \multicolumn{6}{|c|}{ Kto powinien rozwiązywać problemy wsi/gminy } & \multirow{3}{*}{ Ogółem } \\
\hline & & \multirow{2}{*}{$\begin{array}{r}\begin{array}{c}\text { sami } \\
\text { mieszk. }\end{array} \\
9 \\
\end{array}$} & \multirow{2}{*}{$\begin{array}{l}\text { ludzie } \\
\text { tacy, jak } \\
\text { respon- } \\
\text { dent } \\
3 \\
\end{array}$} & \multirow{2}{*}{$\begin{array}{r}\begin{array}{r}\text { mieszkań- } \\
\text { cy przy } \\
\text { pomocy } \\
\text { władz lok. }\end{array} \\
19\end{array}$} & \multirow{2}{*}{\begin{tabular}{|c|}
$\begin{array}{c}\text { władze } \\
\text { lok. przy } \\
\text { pomocy } \\
\text { mieszkań- } \\
\text { ców }\end{array}$ \\
30
\end{tabular}} & \multirow{2}{*}{\begin{tabular}{|c|} 
władze przy \\
pomocy \\
mieszk. \\
i osób \\
takich, jak \\
resp. \\
29
\end{tabular}} & \multirow{2}{*}{$\begin{array}{c}\text { same } \\
\text { władze } \\
\text { lokalne } \\
\\
1\end{array}$} & \\
\hline \multirow{2}{*}{$\begin{array}{l}\text { Kadry } \\
\text { kierownicze }\end{array}$} & $\mathrm{L}$. & & & & & & & \\
\hline & $\%$ & 9,9 & 3,3 & 20,9 & 33,0 & 31,9 & 0,1 & 100 \\
\hline \multirow{2}{*}{$\begin{array}{l}\text { Specjaliści } \\
\text { (inteligencja) }\end{array}$} & $\mathrm{L}$. & 5 & 1 & 26 & 26 & 23 & 2 & 83 \\
\hline & $\%$ & 6,0 & 1,2 & 31,3 & 31,3 & 27,7 & 2,4 & 100 \\
\hline \multirow{2}{*}{$\begin{array}{l}\text { Pracownicy } \\
\text { umysłowi } \\
\text { (biurowi, han- } \\
\text { dlu i usług) }\end{array}$} & L. & 11 & 2 & 36 & 66 & 32 & 14 & 161 \\
\hline & $\%$ & 6,8 & 1,2 & 22,4 & 41,0 & 19,9 & 8,7 & 100 \\
\hline \multirow{2}{*}{$\begin{array}{l}\text { Pracownicy } \\
\text { fizyczni }\end{array}$} & L. & 1 & 1 & 7 & 6 & 2 & 10 & 27 \\
\hline & $\%$ & 3,7 & 3,7 & 25,9 & 22,2 & 7,4 & 37,0 & 100 \\
\hline \multirow{2}{*}{$\begin{array}{l}\text { Właściciele } \\
\text { gosp. rolnych }\end{array}$} & L. & 2 & 0 & 6 & 8 & 8 & 1 & 25 \\
\hline & $\%$ & 8,0 & 0,0 & 24,0 & 32,0 & 32,0 & 0 & 100 \\
\hline \multirow{2}{*}{$\begin{array}{l}\text { Właściciele } \\
\text { firm }\end{array}$} & $\mathrm{L}$. & 0 & 1 & 14 & 13 & 9 & 5 & 42 \\
\hline & $\%$ & 0,0 & 2,4 & 33,3 & 31,0 & 21,4 & 11,9 & 100 \\
\hline \multirow{2}{*}{ Ogółem } & L. & 28 & 8 & 108 & 149 & 103 & 33 & 429 \\
\hline & $\%$ & 6,5 & 1,9 & 25,2 & 34,7 & 24,0 & 7,7 & 100 \\
\hline
\end{tabular}

Źródło: opracowanie własne.

Tabela 7.12. Ocena wlasnego wpływu na rozwiązywanie niektórych problemów środowiska, na zmianę na lepsze sytuacji w miejscowości/gminie wg płci

\begin{tabular}{|l|l|r|r|r|r|r|r|}
\hline \multirow{2}{*}{ Płeć } & \multicolumn{4}{|c|}{$\begin{array}{r}\text { Moje działania i osób takich jak mogą doprowadzić } \\
\text { do rozwiązywania problemów środowiska: }\end{array}$} & \multirow{2}{*}{ Ogółem } \\
\cline { 3 - 8 } & $\begin{array}{c}\text { zdecydo- } \\
\text { wanie tak }\end{array}$ & $\begin{array}{c}\text { raczej } \\
\text { tak }\end{array}$ & $\begin{array}{c}\text { zależy, } \\
\text { w jakiej } \\
\text { sprawie }\end{array}$ & $\begin{array}{c}\text { raczej } \\
\text { nie }\end{array}$ & $\begin{array}{c}\text { zdecydo- } \\
\text { wanie nie }\end{array}$ & \\
\hline \multirow{2}{*}{ Kobiety } & Liczebność & 47,0 & 44,0 & 66,0 & 8,0 & 0 & 165 \\
\cline { 2 - 8 } & $\%$ & 28,5 & 26,7 & 40,0 & 4,8 & 0 & 100 \\
\hline \multirow{2}{*}{ Mężczyźni } & Liczebność & 91,0 & 77,0 & 53,0 & 4,0 & 1,0 & 226 \\
\cline { 2 - 8 } & $\%$ & 40,3 & 34,1 & 23,5 & 1,8 & 0,4 & 100 \\
\hline \multirow{2}{*}{ Ogółem } & Liczebność & 138,0 & 121,0 & 119,0 & 12,0 & 1,0 & 391 \\
\cline { 2 - 7 } & $\%$ & 35,3 & 30,9 & 30,4 & 3,1 & 0,3 & 100 \\
\hline
\end{tabular}

Źródło: opracowanie własne. 
Tabela 7.13. Ocena wlasnego wpływu na rozwiązywanie niektórych problemów środowiska, na zmianę na lepsze sytuacji w miejscowości/gminie wg wykształcenia

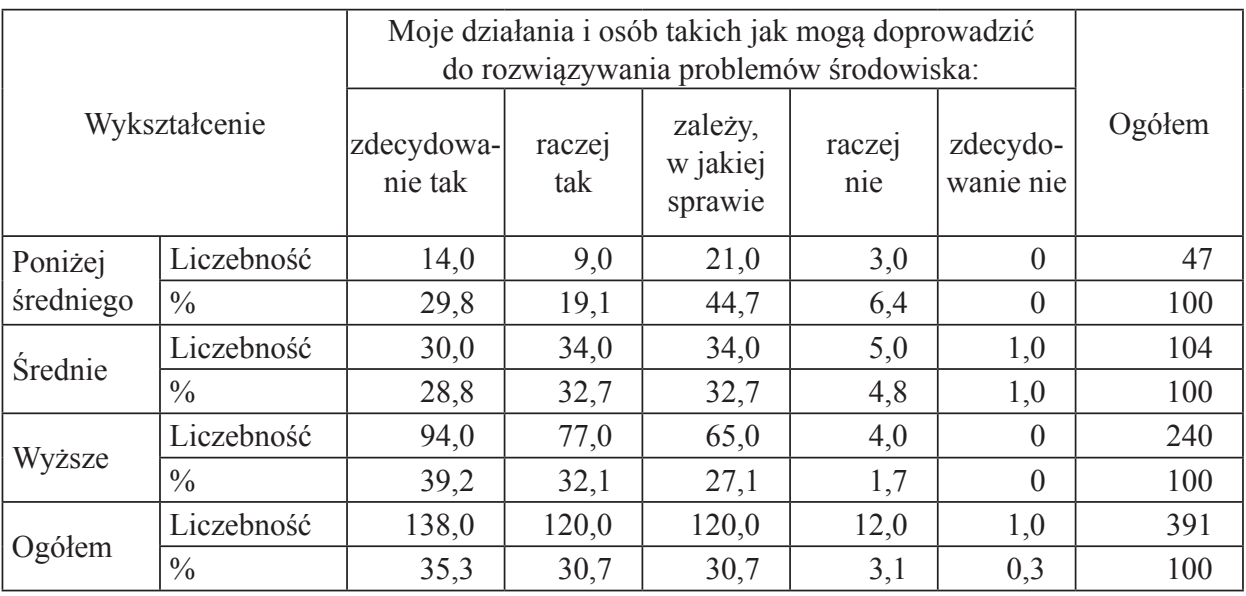

Źródło: opracowanie własne.

Tabela 7.14. Ocena własnego wpływu na rozwiązywanie niektórych problemów środowiska, na zmianę na lepsze sytuacji w miejscowości/gminie wg kategorii zawodowych

\begin{tabular}{|c|c|c|c|c|c|c|c|}
\hline \multirow{2}{*}{\multicolumn{2}{|c|}{ Kategoria zawodowa }} & \multicolumn{5}{|c|}{$\begin{array}{c}\text { Moje działania i osób takich jak mogą doprowadzić } \\
\text { do rozwiązywania problemów środowiska: }\end{array}$} & \multirow{3}{*}{$\begin{array}{r}\text { Ogółem } \\
82\end{array}$} \\
\hline & & \multirow{2}{*}{$\begin{array}{r}\begin{array}{r}\text { zdecydo- } \\
\text { wanie tak }\end{array} \\
46,0\end{array}$} & \multirow{2}{*}{$\begin{array}{r}\text { raczej tak } \\
22,0 \\
\end{array}$} & \multirow{2}{*}{$\begin{array}{r}\begin{array}{r}\text { zależy } \\
\text { w jakiej } \\
\text { sprawie }\end{array} \\
14,0\end{array}$} & \multirow{2}{*}{$\begin{array}{r}\text { raczej } \\
\text { nie } \\
\end{array}$} & \multirow{2}{*}{$\begin{array}{r}\text { zdecydo- } \\
\text { wanie nie } \\
0\end{array}$} & \\
\hline Kadry & $\mathrm{L}$. & & & & & & \\
\hline kierownicze & $\%$ & 56,1 & 26,8 & 17,1 & 0 & 0 & 100 \\
\hline \multirow{2}{*}{$\begin{array}{l}\text { Specjaliści } \\
\text { (inteligencja) }\end{array}$} & $\mathrm{L}$. & 17,0 & 26,0 & 10,0 & 2,0 & 0 & 55 \\
\hline & $\%$ & 30,9 & 47,3 & 18,2 & 3,6 & 0 & 100 \\
\hline \multirow{2}{*}{$\begin{array}{l}\text { Pracownicy } \\
\text { umysłowi (biuro- } \\
\text { wi, handlu i usług) }\end{array}$} & L. & 33,0 & 38,0 & 39,0 & 3,0 & 0 & 113 \\
\hline & $\%$ & 29,2 & 33,6 & 34,5 & 2,7 & 0 & 100 \\
\hline \multirow{2}{*}{$\begin{array}{l}\text { Pracownicy } \\
\text { fizyczni }\end{array}$} & L. & 8,0 & 2,0 & 10,0 & 0 & 1,0 & 21 \\
\hline & $\%$ & 38,1 & 9,5 & 47,6 & 0 & 4,8 & 100 \\
\hline \multirow{2}{*}{$\begin{array}{l}\text { Właściciele gosp. } \\
\text { rolnych }\end{array}$} & $\mathrm{L}$. & 6,0 & 5,0 & 14,0 & 0 & 0 & 25 \\
\hline & $\%$ & 24,0 & 20,0 & 56,0 & 0 & 0 & 100 \\
\hline \multirow{2}{*}{ Właściciele firm } & $\mathrm{L}$. & 11,0 & 12,0 & 12,0 & 2,0 & 0 & 37 \\
\hline & $\%$ & 29,7 & 32,4 & 32,4 & 5,4 & 0,0 & 100 \\
\hline \multirow{2}{*}{ Ogółem } & L. & 121,0 & 105,0 & 99,0 & 7,0 & 1,0 & 333 \\
\hline & $\%$ & 36,3 & 31,5 & 29,7 & 2,1 & 0,3 & 100 \\
\hline
\end{tabular}

Źródło: opracowanie własne. 
Tabela 7.15. Ocena wpływu na decyzje władz lokalnych dotyczące tego, co dzieje się w miejscowości/gminie osób takich, jak respondent wg płci

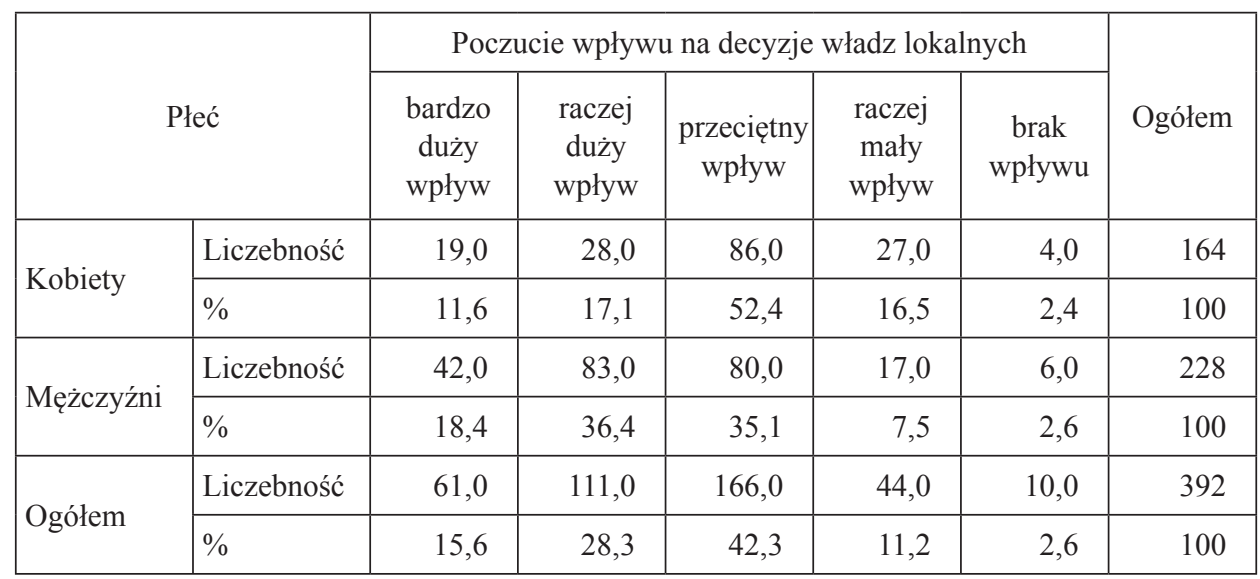

Źródło: opracowanie własne.

Tabela 7.16. Ocena wpływu na decyzje władz lokalnych dotyczące tego, co dzieje się w miejscowości/gminie osób takich, jak respondent wg wykształcenia

\begin{tabular}{|c|c|c|c|c|c|c|c|}
\hline \multirow{2}{*}{\multicolumn{2}{|c|}{ Wykształcenie }} & \multicolumn{5}{|c|}{ Poczucie wpływu na decyzje władz lokalnych } & \multirow[b]{2}{*}{ Ogółem } \\
\hline & & bardzo & raczej & przeciętny & raczej & brak & \\
\hline \multirow{2}{*}{$\begin{array}{l}\text { Poniżej } \\
\text { średniego }\end{array}$} & Liczebność & 5,0 & 13,0 & 22,0 & 4,0 & 1,0 & 45 \\
\hline & $\%$ & 11,1 & 28,9 & 48,9 & 8,9 & 2,2 & 100 \\
\hline \multirow{2}{*}{ Średnie } & Liczebność & 17,0 & 21,0 & 50,0 & 13,0 & 4,0 & 105 \\
\hline & $\%$ & 16,2 & 20,0 & 47,6 & 12,4 & 3,8 & 100 \\
\hline \multirow{2}{*}{ Wyższe } & Liczebność & 39,0 & 77,0 & 94,0 & 27,0 & 5,0 & 242 \\
\hline & $\%$ & 16,1 & 31,8 & 38,8 & 11,2 & 2,1 & 100 \\
\hline \multirow{2}{*}{ Ogółem } & Liczebność & 61,0 & 111,0 & 166,0 & 44,0 & 10,0 & 392 \\
\hline & $\%$ & 15,6 & 28,3 & 42,3 & 11,2 & 2,6 & 100 \\
\hline
\end{tabular}

Źródło: opracowanie własne. 
Tabela 7.17. Ocena wpływu na decyzje władz lokalnych dotyczące tego, co dzieje się w miejscowości/gminie osób takich, jak respondent wg kategorii zawodowych

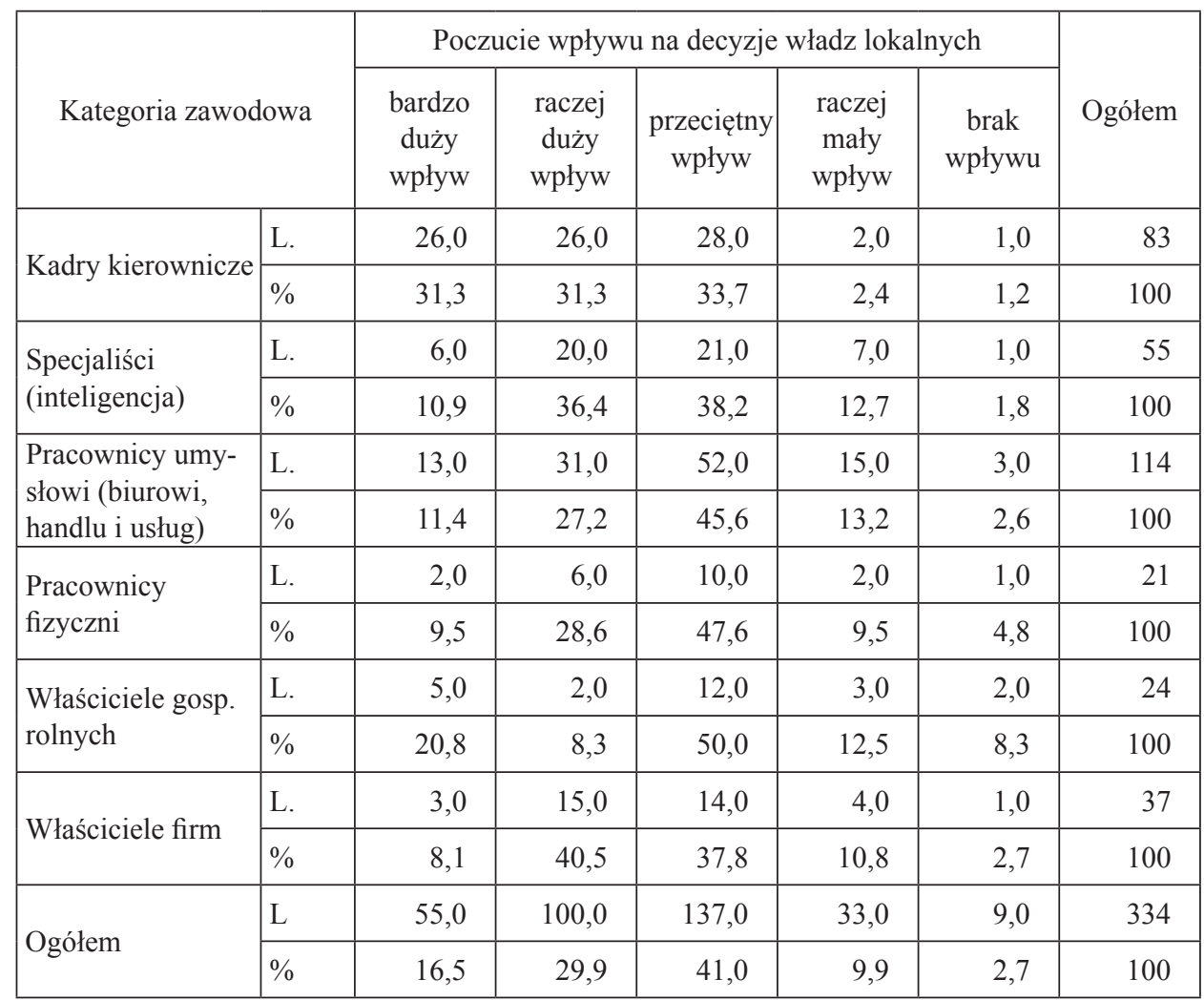

Źródło: opracowanie własne. 



\title{
RESEARCH OF THE SOCIAL CAPITAL OF LOCAL ACTION GROUPS (LAG) - THE CONCEPT FOR RESEARCH, ANALYSIS AND CONCLUSIONS
}

\author{
(Summary)
}

\section{Introduction}

The level of social capital is one of the important factors conditioning sustainable and multi-function development of European and Polish rural areas. The LEADER approach plays an important role in developing this capital. All "editions" of this programme in Poland have contributed to creating and developing territorial partnerships described as Local Action Groups (LAGs). Despite the fact that these structures are still fairly new, they are expected to exert considerable impact on the development of Polish rural areas.

Within the framework of the project funded by the National Science Centre, in the period from 2.08.2011 to 4.04.2013, the research team from the Institute of Sociology of the University of Łódź conducted research studies regarding the structure and conditions of the social capital of LAGs operating in Polish Voivodeships within the smallest (three Voivodeships) and the largest network of these structures (three Voivodeships). The team was interested in LAGs which already implemented the Scheme II and are currently in the process of implementing the 4. Rural Development Programme 2007-2013 as they have been operating long enough to assume that the relationships among their members are relatively stable. This enables us to refer to their features and, in particular, define the relations among the network participants, their mutual trust, norms and values guiding them in their activity.

\section{Methodology assumptions for the study}

Implementation of the research project was to ensure extension of our theoretical knowledge regarding the significance and specificity of Polish Local Action Groups in the context of the social capital theory as well as provide the application dimension. Thus the research has been based on two types of premises: cognitive and application factors.

The most important research objectives assumed:

- recognition of the level and structure of Local Action Groups' social capital in six selected Polish Voivodeships;

- diagnosis of its social and economic conditions;

- determining whether the level of Voivodeship saturation with Local Action Groups (small or relatively large network of LAGs) is a factor diversifying the level, structure and character of these partnerships' social capital. 
The assumed practical objectives include:

- contributing to extending the knowledge of LAG participants and institutions responsible for implementing the LEADER approach in Poland as regards conditions and results of its implementation for the purposes of mobilisation of local communities and rural development. The 2012 report elaborated by PSDB (Ocena funkcjonowania LGD realizujacych LSR w ramach PROW 2007-2013 [Assessment of operation of LAGs implementing LDS within the framework of RDP 2007 - 2013]) states that $50 \%$ of LAGs do not conduct any research regarding their operation;

- submitting comments resulting from the analysis of collected materials to institutions involved in improving procedures connected with the LEADER approach.

The theoretical framework of the research is based on the social capital concept formulated by R. Putnam, who states that "Social capital refers to features of social organisation, such as trust, norms and networks that can improve the efficiency of society by facilitating coordinated actions". The result of a higher level of social capital is more intensive involvement of a part of a community in actions contributing to resolving their common issues. The three variables, i.e. trust, norms and networks, condition, reinforce and cumulate one another. Persons who trust other citizens are more frequently involved in social activities, participate in social and political actions, operate within local organisations and provide money for charities. However, the level of their social trust is determined by adopted and accepted norms and values which are common in a society, in particular the norm of general reciprocity, truthfulness, solidarity and subjectivity.

The conclusions resulting from the research were to determine the level of LAGs' social capital and (in the case of the decomposed capital) its weakest components (trust, norms and values or networks) requiring support plus the possible consequences of the above for implementing the LEADER approach. Better cohesion of social capital may potentially contribute to enhancing effectiveness of LAGs' activity for the benefit of multi-function and sustainable development of rural areas and development of their civil societies. The results of the analysis were to constitute the basis for suggesting methods and mechanisms of reinforcing the weakest components.

Another key element of R. Putnam's concept is the definition of two social capital dimensions described as bonding social capital and bridging social capital. These dimensions are characteristic for different types of social networks. The bonding capital is characteristic for exclusive societies with a closed social network focused on participants' needs and interests, of strong solidarity bonds present particularly within a group, high level of network participants' trust for familiar persons. However, this level of trust is much lower as regards unfamiliar persons. The bridging capital is visible in open social networks whose participants have internalised norms and values contributing to both internal and inter-group cooperation and have a relatively high level of trust as regards strangers.

Such facts as the social capital character (bonding or bridging) and whether the participants create an open or closed network have impact on mobilisation of rural areas residents and creating possibilities of inclusion into the transformation process within their area of residence.

In order to examine the level and structure of the social capital of Local Action Groups, questions included in a survey questionnaire were used. The detailed issues included variables related to the three components of the capital:

The following variables have been used to determine the trust factor:

- LAG's members trust as regards familiar persons (family, neighbours, colleagues from outside and inside a given LAG);

- social trust (as regards strangers) of LAG's members (i.e. conviction that the majority of people are trustworthy and trust as regards strangers encountered in different life situations);

- LAG's members trust as regards local institutions and organisations (local authorities, non-governmental organisations, local entrepreneurs). 
The following values have been analysed as the norm component variables:

- LAG participants' local patriotism, i.e. bonds with their commune of residence, participation in the latest local governmental elections, willingness to bear financial costs connected with promoting the local culture;

- values and norms shared by LAG's participants, i.e. the value of partnership understood as a cohesive area as regards the environment, economy and culture; the norm of the duty of ensuring multi-sectoral cooperation; necessity of LAG participants' familiarity with the LAG operation procedures:

- commitment to the community of the surveyed, i.e. readiness to help others, willingness to continue to be a member of a LAG; level of the feeling of subjectivity of the surveyed (exercising control over their own lives).

The following network norm variables have been defined:

- involvement of LAG's participants in the networks of cooperation for a partnership or commune, i.e. working for commune residents; participation in promoting the local culture;

- participation of the surveyed in LAG's activities, i.e. assessment of their activity in LAG's operation while implementing the II PPL + scheme, frequency of participation in general meetings of a LAG, flow of information as regards these meetings among LAG's participants, types of meetings, implemented projects;

- LAG participants' feeling of having influence on the partnership operation, i.e. participation of LAG's members in group's decision-making processes, subjects of the network (leaders, LAG's organisational structures representatives) most intensively engaged in the group's operation, conviction that LAG's activities exert impact on partnership development.

In order to examine the impact of social conditions on the level and structure of the Local Action Groups' social capital, the following available present data (mostly from the Local Data Bank) has been used:

- number of active Country Housewives' Clubs and other traditional forms of cooperation among rural areas residents (Volunteer Fire Department) in the partnerships areas in 2010;

- number of new type active non-governmental organisations operating within the partnerships areas (i.e. established after 1989 and being legal entities) plus ordinary associations in 2010;

- dynamics of the increase in the number of LAGs in a Voivodeship.

Similarly, the impact of economic conditions on the level and structure of the LAGs' social capital has been examined on the basis of data regarding: structure of farmsteads within partnerships areas in 2010; unemployment rates within partnerships areas in 2010; number of agricultural manufacturers within partnerships areas in 2010; number of companies run by natural persons outside the agricultural sector within partnerships areas in 2010.

The conditions of LAGs' social capital connected with the cooperation among the social, public and economic sectors within their operation areas include: various dimensions of cooperation among the social, public and economic sectors within the partnership area (formal and legal dimensions, cash flows, interactions among sectors); local leadership and authority of local governments.

Five research hypotheses have been formulated:

1. LAGs' social capital has features of a decoded capital. In particular, there are no significant statistic dependencies among components of this capital.

2. The network component has the lowest level within the LAGs' social capital structure.

3. The higher the level of social activity within the area for the benefit of which LAGs operate, the higher the level of their social capital.

4. The lower the level of economic development within the area for the benefit of which LAGs operate, the lower the level of their social capital.

5. The higher the level of cooperation among social, public and economic sectors within the area for the benefit of which LAGs operate, the higher the level of their social capital. 
The research has utilised a "multiple case study" where, within the framework of the same research process, several cases are analysed and compared in order to provide a theoretical generalisation.

Several techniques have been used to achieve the objectives assumed within the research approach employed. First of all, an individual survey targeted at members of LAGs' operating within selected Voivodeships was conducted. The collected data was used to estimate the level and structure of the LAGs' social capital. Among 1500 surveys handed out, 586 were filled in. Due to their content (in particular lack of data), 573 were qualified for further research.

Secondly, analysis of the present materials was carried out. Thirdly, phone interviews with the personnel of commune offices included in the analysed territorial partnerships were carried out.

The present materials and data obtained by means of phone interviews enabled us to collect information necessary to determine the independent variables in included in the conditions of the social and economic sphere of the LAGs' social capital and conditions of its level connected with the cooperation among the public, social and economic sectors within the partnerships areas. The list of projects most important for LAGs was also elaborated.

\section{Research procedure employed for analysing the social capital of selected territorial partnerships}

Taking into account the list of LAGs operating in individual Voivodeships of Poland, the analysis included organisations from the Lubuskie, Opolskie and Zachodniopomorskie Voivodeships (included in set I, i.e. Voivodeships of the smallest LAG networks) and Małopolskie, Podkarpackie and Wielkopolskie Voivodeships (included in set II, i.e. Voivodeships most intensively "saturated" with organisations of this type).

All groups operating within the selected Voivodeships were requested to participate in the survey (59 LAGs). Over 50\% of their representatives granted their consent to participate in the survey (34 LAGs) including 9 out of 14 LAGs within set I and 25 out of 45 LAGs within set II.

Set I includes: 1. three LAGs from the Lubuskie Voivodeship (associating residents of 24 communes); 2. three LAGs from the Opolskie Voivodeship (associating residents of 17 communes); 3. three LAGs from the Zachodniopomorskie Voivodeship (associating residents of 29 communes).

Set II also includes LAGs from three Voivodeships: 1. Wielkopolskie Voivodeship, i.e. 5 partnerships associating residents of 35 communes; 2. Małopolskie Voivodeship, i.e. 11 organisations associating residents of 47 communes; 3. Podkarpackie Voivodeship, i.e. 9 organisations associating residents of 46 communes.

103 surveys from LEG members included in set I and 470 surveys from LEG members in set II were obtained.

The first stage of the analysis included description of the level and structure of social capital of the whole set of LEG members following elaboration of their social and demographic characteristics. The second stage included the comparison of the social capital features of set I and II. Attention was paid to the social and economic conditions possibly influencing their shape.

The formulated research hypotheses were verified on the basis of an in-depth comparative analysis of data including views of 103 respondents from set I and 184 respondents from set II.

The description of all partnerships and characteristics of all members/partners of LAGs (both social-demographic and regarding their social-political activity) is provided in the Chapter II.

We must stress the fact that the surveyed LAGs' members have a high level of social capital resulting from their high level of education, social and political activity, significant professional standing and the sense of having control over their lives. This is hardly a surprise as the surveys were filled in more willingly by persons involved in territorial partnerships' activity and having ex- 
traordinary resources within this scope. Moreover, their decision regarding participation in a given LAG had been preceded by other various forms of activity. The social-demographic characteristics of LAGs' members (human capital level) and their social capital generated outside the LAGs' structures may, at least partially, determine the relatively high level of social capital of the analysed partnerships. Furthermore, the social capital within the framework of LAGs is multiplied by persons having a high level of this capital prior to joining these structures. They stood the best chance of being selected as members of management boards or councils. The analyses of active citizenship showed that these persons belonged to the circle of activists operating also in this area, e.g. this group had higher attendance in the latest local elections and more eagerly participated in activities connected with the election campaigns. Moreover, a higher percentage of these persons declared their willingness to run for the local administration posts during the next elections.

Following the characteristics of the studied community, the studied LAGs' social capital structure was analysed by means of the selected indicator variables described above which enabled us to estimates the level of the following three components: trust, norms and values as well as networks. Next, their mutual relationships were established in order to determine whether the LAGs' social capital is cohesive. The level of the LAGs' social capital as a certain whole (i.e. the sum of their determined components) was also estimated.

\section{Basic results and conclusions of the study}

The characteristics of the LAGs' social capital trust component resulting from the analysis of the variables of the private sphere trust (trusting familiar persons), generalised trust and variables of the public sphere trust (trusting institutions operating in the three sectors significant for LAGs' operation) make it possible to formulate the below-mentioned conclusions.

Almost all participants trusted not only their families ( $98 \%$ of the total number), but also their colleagues from a LAG ( $96 \%$ of these persons). However, if they were to indicate a group of colleagues from a given LAG whom they trusted the most, usually they chose representatives of a sector other than the one they originated from. The participants declared the relatively lowest level of trust (generally in the analysed partnerships) for the economic sector representatives. This confirms the results of other studies showing a relatively low level of trust in local communities as regards private entrepreneurs perceived as entities unwilling to get involved in activities not resulting in their direct material benefits. Only a little more than $50 \%$ of colleagues trusted the LAGs' members representing the economic sector. The public sector representatives were particularly mistrustful towards them. Presumably, the lower level of trust as regards the LAGs' members representing the economic sector may limit the process of extending the partnerships with new representatives. A slightly higher percentage of the respondents (65\% of the total number) trusted the LAGs' participants representing the public sector. The social sector representatives appear to be most trusted, i.e. $72 \%$ respondents from the public sector, $63 \%$ respondents from the economic sector and $75 \%$ respondents from the social sector declared trust as regards these entities.

The significant majority of the respondents ( $90 \%$ of the total number) trusted also colleagues not belonging to a LAG, however, a slightly lower percentage of respondents ( $79 \%$ of the total number) placed their trust in neighbours. This may result from the specificity of rural neighbourhoods to which both positive (neighbourly aid) and negative features (excessive interest in private lives of persons living next-door, at the same street, in the same town constituting a group of comparative reference as regards the individual professional or material status) are attributed.

Generally, $60 \%$ of the surveyed LAGs' members trust all the three above-mentioned categories of familiar persons (i.e. neighbours and colleagues belonging to LAGs and operating outside of them). 
A relatively low level of trust placed in strangers (encountered in various life situations) may be observed, i.e. this trust was expressed by only $19.8 \%$ of the total number of the surveyed, however, $2 / 3$ of the community declared that they trusted the majority of other people.

The general social trust indicator synthesizing both described variables has the lowest value among all the elements of the trust component. Simultaneously, this kind of trust (placed in strangers encountered in different life situations) determines the tendency to establish various social relations, facilitates the access and acquisition of information which may result in constructing varied types of social capital resources. This coincides with the view that shortage of generalised social trust and effective institutions regulating the social and economic relations results in the fact that the tendency to undertake new activities (particularly in the economic sphere) shows a downward trend or becomes a pathology.

While examining the vertical trust expressed by LAGs' members, its relatively low level was noticed (taking into account the specificity of partnerships' operation and their composition). Only $1 / 3$ of the surveyed placed considerable trust in the majority of the singled out types of local institutions. The institutions in which the relatively largest group of the surveyed placed no trust at all included local authorities and local entrepreneurs (every fourth respondent declared the total lack of trust in both cases), however, the institutions generating at least moderate trust among the largest percentage of the surveyed were non-governmental organisations (mistrusted only by $15 \%$ of the respondents).

However, the research also showed that, in numerous cases, these organisations are not perceived as independent guardians of the public interest but as entities entangled in different relations with local authorities and without clearly defined operation objectives.

The characteristics of the phenomena included in the first singled out component of social capital indicate its internal diversity. While the trust placed in familiar persons encountered in every-day situations is relatively considerable (its synthetic indicator amounts to 1.54 in the $0-2$ scale), the trust placed in local institutions (the average indicator value amounts to 1.21 in the $0-2$ scale) and, in particular, the trust placed in strangers (the average indicator value amounts to 1.02 in the $0-2$ scale) remain on a relatively low level. The average level of the trust component as expressed in the scale from 0 to 6 points (in the surveyed group) amounted to 3.79 points.

The characteristics of the components of norms and values shared by the LAGs' members including LAGs' members local patriotism, their declared commitment to the community, perceiving the territorial partnership as a value, and the norm of the duty of ensuring multi-sectoral cooperation as well as the necessity of LAG participants' familiarity with the LAG operation procedures have indicated the below-mentioned features of this component.

The analysis of individual elements has shown that the surveyed persons are local patriots. The vast majority of these persons do not intend to leave their commune. As many as $3 / 4$ of the surveyed is ready to provide money for promotion of the culture of the region included in LAG's operation. The respondents not only participated in local governmental elections but a large number of them ( $58 \%$ of the total number) participated in preparing an election campaign or activities for the benefit of a candidate or a party/electoral committee. Over $50 \%$ of the respondents considered running for the post of a councillor, commune head or mayor, justifying this decision with their willingness to act for the benefit of the commune residents. The partial results of the study were reflected in high values of the synthetic local patriotism indicator as regards the members of individual groups surveyed. The average value of this indicator (scale from 0 to 2 ) was 1.75 .

Within the framework of the component, the analysis included norms and values connected with LAG participants' membership in this organisation, i.e. their willingness to represent the partnership's interests and ensure the largest possible cooperation for its benefit among all members of the group as well as the belief that it is necessary to be familiar with the procedures connected with LAGs' operation. The surveyed declared that they are aware and accept the operation for 
the benefit of the whole partnership (not only their communes) and their activity in a LAG must be undertaken for the benefit of the community and not in order to ensure particular interests.

This motivation to act within a local group may be a factor facilitating its members' cooperation for the benefit of the residents included in the partnership.

For the community surveyed, the average value of the indicator regarding the norms and values connected with LAG's membership was 1.49 (scale from 0 to 2).

The results regarding respondents' commitment to the community and subjectivity showed that almost $50 \%$ of the surveyed LAG's members felt they had a high level of control over their lives (subjectivity) and believed in the necessity to take other people's interests into account while looking after their own interests (expressing sensitivity to others' needs and willingness to provide help).

The average value of the social norms synthetic variable indicator was 1.48 (scale from 0 to 2). The high values of indicators connected with all variables included in the synthetic component of norms and values also directly influenced the value of its collective measurement. The average value of the component of norms and values in the group surveyed amounted to 4.73 (scale from 0 to 6 points) and appeared to be the highest one among the average values of all social capital components.

The network component included three multi-element constituents, i.e. respondents' involvement in the network of cooperation for the benefit of a local community (partnership or commune), respondents' participation in LAGs' operation and the LAGs' members feeling that they have influence on operation of the partnership. Approximately $3 / 4$ of LAGs' members worked for the benefit of citizens in: public institutions (e.g. public servants, councillors and commune heads), non-governmental organisations, individually or in cooperation with other residents of a commune. Approximately $30 \%$ of the surveyed acted in at least 3 different forms. $71 \%$ of them (prior to entering a LAG) also participated in events connected with promoting the cultural heritage of the area included in organisation's operation.

$25 \%$ of the respondents scored the highest value of the variable, i.e. involvement in different types of activities for the benefit of a local community (including promotion of local culture). The average value of this variable amounted to 1.11 (scale from 0 to 2 ). The respondents' activity within the framework of a LAG itself also had different forms.

It is worth mentioning that approx. $15 \%$ of persons are only passive, formal members of a partnership and over $12 \%$ describes their operation as "below average". Some respondents (approx. $14 \%$ ) justified this state of affairs with the lack of objective possibilities to take certain actions which "are systematically delegated to a certain group of the same persons", while $11 \%$ of the respondents concluded that they did not participate in initiatives implemented for the benefit of the residents of communes included in the partnership area because they had not been informed about them. This may indicate inefficient communication among entities, their offices and LAG's members.

Certain publications stress the fact that LAGs are subject to professionalization and economisation. This results from the considerable impact of offices on LAGs' operation and bureaucratic procedures limiting the grass-roots' possibility to participate in every-day operation of partnerships. The activity undertaken in LAGs differs from the activity undertaken in rural non-governmental organisations as the familiarity of legal and financial procedures, regulating operation of a LAG, is required. Approximately $71 \%$ of the surveyed stated that all the members of a group should be familiar with bureaucratic procedures which are quite complicated. The ongoing experiences have shown that implementation of PPL + resulted in numerous difficulties and, according to respondents, required considerable involvement as well as enhancement of skills and competences. This experience has positive impact on the current programming period. Another stage of the LEADER approach implementation was considered as slightly easier by the respondents. Their activity in partnerships resulted not only in new experiences and know-how or enhancing civic-mindedness but also new ideas as regards streamlining the procedures defining LAGs' operation. The LAGs' leaders, being 
mostly members of their Management Boards and Councils, have the most extensive knowledge regarding their operation. However, it is puzzling that only $38 \%$ of them know the meaning of the "multi-functional development" term and $54 \%$ of them are familiar with the "sustainable development" term. Unfamiliarity with these terms may hinder their understanding of the policy of rural areas transformation.

Over $90 \%$ of the surveyed are sure that LAGs have positive impact on the social and economic processes present within the partnership area.

The synthetic indicator of persons' confidence that they exert impact on partnership's operation scored a relatively high average value amounting to 1.23 (scale from 0 to 2 ). The average value of the network component was 3.53 (standardised 7-point scale including the 0-6 range of points).

It was assumed that all the described questions regarding applicable indicators making it possible to estimate the value of individual components had the same weight and they were included in the social capital index. After summing them up, numeric values were obtained illustrating, in a synthetic form, firstly, the level of each component and, finally, also the level LAGs' social capital.

The synthetic social capital scale potentially included 19 points. However, it appeared that six theoretically lowest values of the scale were not empirically present. Generally, the level of the analysed variable within the whole community is high and its average value amounts to 11.93 . In relation to this value, the level of social capital of LAG members (scale: very high, high, average, low and very low) has been estimated and interpreted.

Approximately $40 \%$ of the surveyed were characterised with the average level of the analysed variable, $30 \%$ were characterised with a value above the average and the remaining $30 \%$ were characterised with values below the average. Fewer than $6 \%$ of the surveyed were characterised with a very high level of social capital and a little below $10 \%$ of the respondents were characterised with a very low level of this capital.

A relatively high level of LAGs' social capital results, at least partially, from its members' social and demographic characteristics (human capital level). Not all LAGs' members constitute are characterised with an equally high level of social capital. High values of the social capital synthetic variable are ascribed mostly to persons having higher social positions represented by higher prestige and income.

The component of norms and values achieved the relatively highest level in the surveyed community. Over $60 \%$ of the surveyed were characterised with an above-average value of this variable while the above-average value of the trust component was ascribed to $33 \%$ of the surveyed $(20 \%$ as far as the network component is concerned). In order to describe the cohesion of social capital as a whole consisting of different components, the analysis of their relations has been carried out.

The relations among the analysed social capital components are not strong enough to support the claim of its cohesion.

The dependency $(\mathrm{r}=0.31)$ between the component of norms and values and the network component is relatively the strongest. The trust component is least connected with other social capital components, which may indicate weak current basis of cooperation within the framework of LAGs and future unwillingness to establish new contacts and create new networks. This thesis is supported by the research observation stating that the actual cooperation in partnerships often takes place within the framework of a limited and frequently closed circle of persons holding (for a long time) the highest positions in LAGs' decision-making bodies.

Thus the hypothesis of the decomposed character of LAGs' social capital has been verified and the network component has appeared to be the weakest one.

The observed weak (at most) connections among the analysed social capital components enable us to notice problems connected with mobilising rural and small-town local communities. Support for the process of creating new cooperation networks may be effective if the level of trust expressed by members of these communities grows (particularly the generalised trust). The current method 
of organising the studied LAGs' structures (in different ranges) may limit the participation of their different members in the decision-making processes. This fact questions implementation of certain rules defined in the LEADER approach, e.g. the rule of partnership and bottom-up approach.

During the comparative analysis of the two studied sets (I and II), it has been concluded that the level of the social capital of organisations belonging to set II (Voivodeships with the largest number of LAGs) was lower and the structure of this capital was more dispersed. The social capital of groups included in set I seems to be more cohesive and its level is higher. It is a careful interpretation due to the fact that much fewer members of set I took part in the voluntary study and the participants included the most active persons, characterised with a high level of human capital. Moreover, social capital regarding trust was mostly based on its horizontal aspect. The consequence of this state of affairs may be the fact that the participants of this set are more willing to cooperate with persons they know well. Their actions may be connected with dealing with issues concerning a relatively narrow range of partnership residents. It may be assumed that their high level of social capital is more bonding than bridging.

While verifying the last three hypotheses (influence of the economic and social activity within partnerships areas and inter-sectoral cooperation on the LAGs' social capital level), results have been obtained which do not confirm the speculations included in them.

So the results of the analyses carried out have not confirmed the hypothesis that a higher level of economic development generates a higher level of social capital. The relatively highest level of social capital has been observed in members of LAGs located within areas of an average economic development level. This result does not confirm the R. Putnam's thesis regarding the dependency between social and economic capital. This may indicate that the level of partnership area development that is too high does mobilise its residents to take actions aimed at introducing changes and the level that is too low does not provide sufficient conditions for taking such actions.

It has also been shown that the dependency between the social activity level within partnerships areas and the level of their social capital has a reverse direction. The lowest average values of social capital have been observed within LAGs operating in areas where the largest number of social organisations is registered and the highest average values of social capital have been observed in areas where the number of such organisations is relatively small. The high level of the social capital of members of LAGs' located in areas showing a relatively low level of social activity may result from the actual involvement of persons expressing relatively high level of social trust and believing in the fact that taking actions for the benefit of this partnership is necessary and justified, in the case when the area residents are passive.

The character of the data obtained (lack of information, reliability of documentation impossible to be verified) does not allow us to unambiguously state whether the scope of the three-sector cooperation implemented in the communes supported by LAGs has any influence on the level of social capital of LAGs' members.

\section{Practical conclusions}

The research carried out has indicated presence of social capital features decomposition showing, e.g. insufficient relations between the respondents' declarations regarding the motives and values directing their actions and actually undertaken activities within a network. The weakness of the LAG cooperation component is an important disadvantage, taking into account the essence of the LEADER whose implementation is based on active cooperation among representatives of three sectors.

The issue that must be analysed by practitioners is elaboration of methods ensuring reinforcement of the network of relations in a manner ensuring more extensive participation of all partnership 
members in its operation. We must analyse the need for such changes in organisational structures which would make it possible to enhance the possibility of grassroots' participation in decision-making processes thus reinforcing one of the important partnership rules, i.e. the "bottom-up approach".

The structural problems also include the decisions regarding the size and scope of partnership operation. Some structures are too large and hinder systematic contact of their members with decision-making and executive bodies. The demands regarding further extension of partnership limits justified by more beneficial financing of projects implemented by larger LAGs are incompatible with the essence of the LEADER approach, i.e. support for rural development whose vision was to be shaped and implemented by the largest possible communities located within areas of LAGs' operation.

The "three-sectoral cooperation rule" should be adjusted or corrected as appropriate. The research shows that representatives of the private sector expected (by the public opinion) to show entrepreneurial spirit remain somehow in the shadow of the operation of partnerships as a whole (not to mention the fact that their colleagues place a relatively lowest level of trust in them). The boundaries between the public and social sector sometimes dissolve as regards the representatives of these sectors who sometimes play a double role, i.e. a public institution employee and non-governmental organisation activist. There is also the issue of the method of making the social sector independent from sometimes excessive influence of local authorities and establishing relations between these entities according to the ,auxiliarity” rule. How to prevent the process of excessive municipalisation of active forms of operation in local communities resulting from bottom-up initiatives?

The research shows that the broadly-defined social communication in territorial partnerships must be improved. All partnership residents should be provided with all information regarding both the rules of LAGs' operation and current forms of operation as well as projects (to be created or implemented). It is also necessary to train a broader scope of grassroots and persons fulfilling given functions in order to supplement and extend their knowledge as regards the essence of partnerships or interpretation of rules aimed at improving European, as well as Polish, rural areas (including multi-function, sustainable development). 